\title{
THE BOOK OF THE \\ BAYEUX TAPESTRY
}

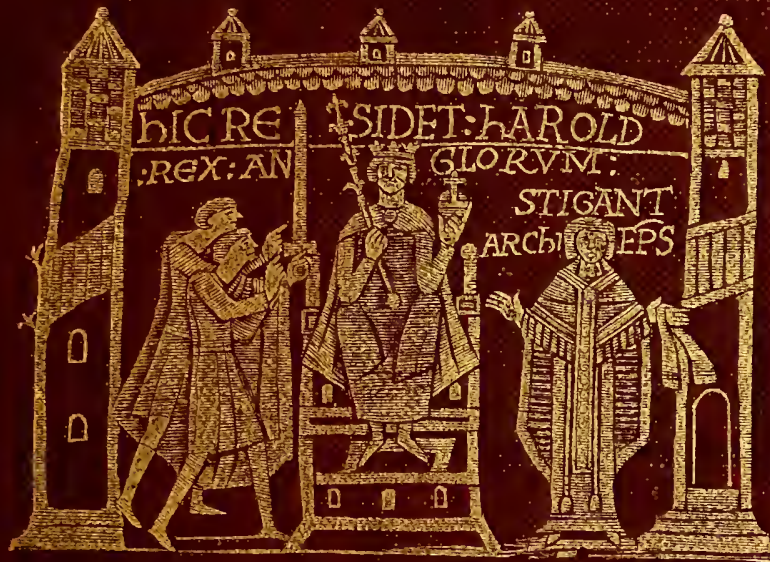

HILAIRE BELLOC 


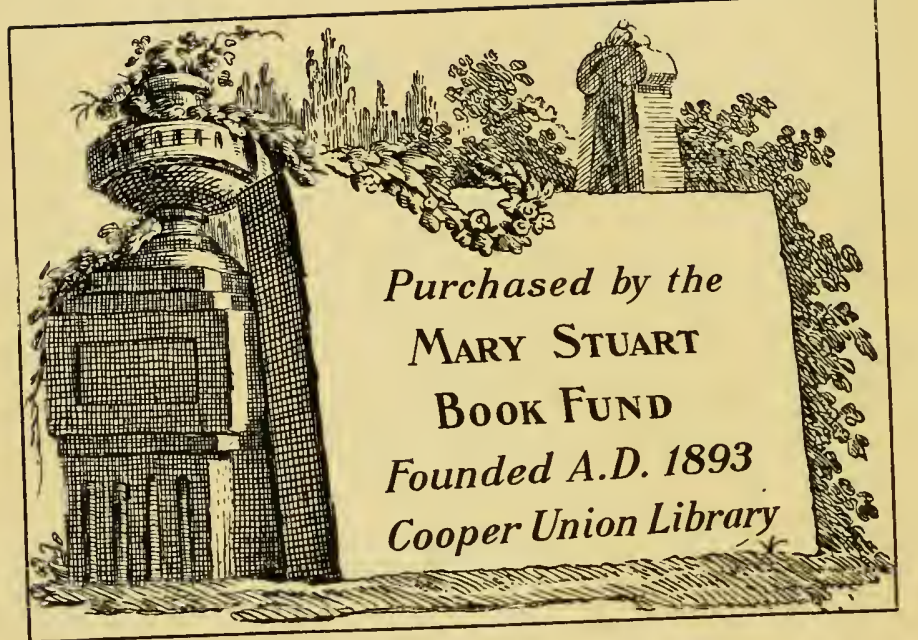




THE BAYEUX TAPESTRY 

. 


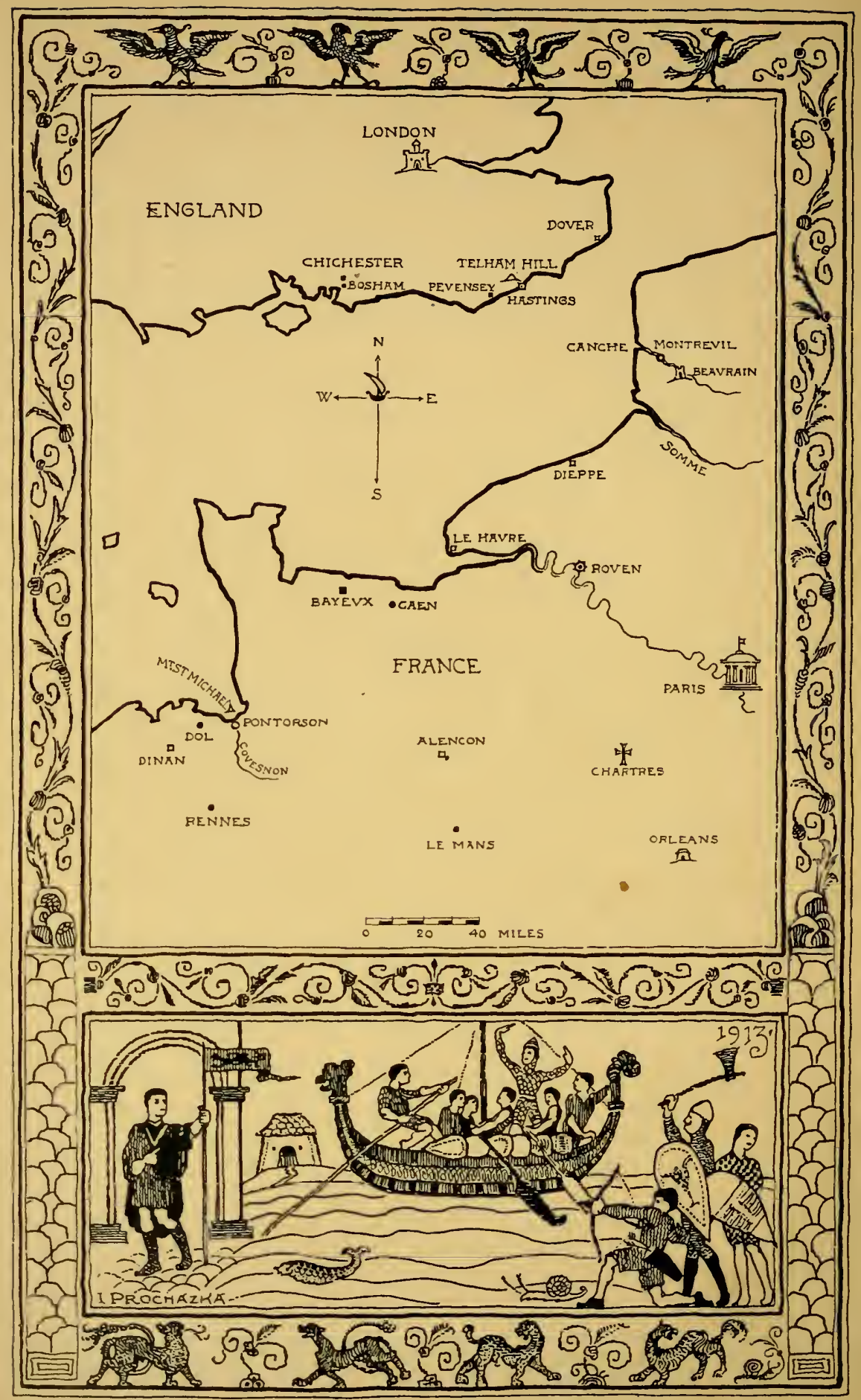




\section{THE BOOK OF THE}

\section{BAYEUX TAPESTRY}

PRESENTING THE COMPLETE WORK IN A SERIES OF COLOUR FACSIMILES: THE INTRODUCTION $\Xi$ NARRATIVE BY HILAIRE BELLOC

\section{LONDON \\ CHATTO \& WINDUS \\ 1914}





\section{INTRODUCTION}

$\mathrm{A}^{\mathrm{T}}$ Bayeux in Normandy, a little town as old perhaps $\mathrm{I}_{\text {as our race and older certainly than our records and }}$ our religion, there is to be seen in the main room of what was once the Bishop's Palace a document unique in Europe. There is no other example, I think, of a record, contemporary or nearly contemporary, of an event so remote in the story of Christendom, detailed upon so considerable a scale and relating to a matter of such moment. It is these three characters combined which give to the Bayeux Tapestry its value. We have, indeed, pictorial representation more accurate and more detailed in some few cases, but relating to the periods when material civilisation was high-betore the Dark Ages. We have again an ample store of evidence pictorial and written, relating to the vivid life of the earlier Middle Ages, and of course, an overwhelming mass of matter dealing with everything that accompanied or has succeeded the Renaissance. Even of the Dark Ages and of that violent and happy transition from the Dark Ages to Mediæval civilisation, we have here and there sharp pictures-mostly pictures of the pen and not of the pencil. But these pictures relate-almost always-episodes which were not the capital episodes of their time. The Bayeux Tapestry stands quite apart in this: that it represents so faithfully and so thoroughly 


\section{THE BAYEUX TAPESTRY}

one of the half-dozen acts essential to the remaking of Europe, and that it so represents an act which, on the analogy of every other of that early time, we should expect to receive only from a short and doubtful literary account. It is the one picture we have of any magnitude showing us the things of the Crusading turningpoint. For Western Christendom, as we know, awoke from its sleep and flowered into the Middle Ages through three great efforts: The Norman Adventures, the Reform of the Church under St. Gregory VII, and the Crusading March. All these were the product of a sort of spring which came upon our ancestry more than eight hundred years ago, and which restored in a renewed form the civilisation of the West. Of that spring the Bayeux Tapestry remains the one piece of ocular description which has survived.

Unfortunately, there must be added to this statement (which would be final if we could be certain of our dates) a critical warning. The date of the work is not certain. I will set forth in a moment the arguments which have been put forward for fixing the work to this or to that moment. We can happily be certain beyond reasonable doubt that it was produced within the lifetime of men who could remember the Invaders of England. It is not later than that. It has even been believed to be actually contemporary with the Invasion itself, and produced under the direction of those who took part in the expedition. But though it is virtually a contemporary document, even if we find ourselves compelled to accept the lower of these limits, yet we unfortunately have not a definite proof of the year or years in which the work was finished. This is the one 


\section{INTRODUCTION}

point which mars our satisfaction in our possession of this thing. It is here worthy of curious remark that the history of the English is singularly fortunate in the wealth of record which it has at call. No other nation has such an accumulation of ancient testimony to hand. No other nation has such a document as the AngloSaxon Chronicle or as the Doomsday Survey, and, by an accident both of civil and of religious history, no other nation has preserved through the revolutions of a thousand years so much material record undestroyed.

When a man first sees the Tapestry at Bayeux his immediate impression and his most vivid one is the impression occasionally, but rarely, produced by some perfect architectural relic-an impression of liveliness as though time had been telescoped up for his advantage. I say that this impression is rare, but when we do get it, it is violent. You feel it in the "immortal marble undecayed " of a portrait bust of the Mediterranean ; in the sharp colouring of the funereal inscriptions of Constantine; in the flagstones and the columns of the Forum at Timgad. It is exceedingly difficult to convey in language this shock which the eye receives when centuries seem to drop out and the action of men to be brought up from the remote past to the present as an object is brought up from the remote distance to the foreground through the action of a lens. I can best compare it to the shock which the mind receives upon hearing after many years, and long after it has been thought forgotten, a familiar voice; or to that similar arrest that our whole being suffers when we smell some smell which went with a whole experience of youth. I say it is very rarely that a surviving monument of the vii 


\section{THE BAYEUX TAPESTRY}

remote past will give this shock. Most antique material things carry deeply bitten into them the evidences of decay. But now and then (the Gospel of St. Chad at Lichfield occurs to me as I write) you get freshness and, as it were, companionship from something which belongs to the dead, who have been dead so long that the very style of their lives has vanished. All this you get when you first see the canvas at Bayeux.

It must next be clearly understood in what convention and with what purpose those who made this embroidery worked.

The object of all this kind of work in every age where it has flourished (and such ages cover nearly the whole of human history) is to establish a record. The motive is "lest the deeds of those great men, our fathers, should perish." Now, there are a hundred ways of satisfying that motive more or less. The one that first occurs to us to-day is of course Inscription. But Inscription suffers from two faults: first, it is not universal; secondly, it is jejune.

It is not universal, because the written characters and the language which they express cannot be universal. They may be lost, or they may become provincial and neglected. It is jejune because full experience is not to be crowded into even an excess of words. You will find in Normandy (not a day's walk from Bayeux, by the way) a very long inscription to a local personage of the third century. It is in Latinthat is, in the most universal of literary mediums-and yet it has served principally for the quarrels of archæologists. There is no prime term in any early inscription that will not serve for such a quarrel, simply because viii 


\section{INTRODUCTION}

language is an imperfect symbol. You are pleased to understand to-day the inscription upon a bronze tablet let into the wall of a public building and thus inscribed:

"This Foundation Stone was laid by the Rev. Charles Woodle, M.A., on the occasion of the Second Jubilee of Her Gracious Majesty Queen Victoria."

You understand what it means. A few centuries hence (if the language has survived), one determining symbol after another will be a matter of dispute. Men will be arguing what "Rev." means, what "M.A."; perhaps what "Jubilee," what "Gracious"- and all the rest of it. The word "Foundation" will give them a good deal of trouble.

What is the alternative? If record by verbal symbol is so imperfect and if all symbol must be sensual, what other sense can we approach? Humanity has never made anything of the symbolism of music, and never will. It is not fixed. There remain only the eye and the picture meant for the eye. Now in a picture, however rude or however perfect, whether in the flat or the round, you get the most permanent record. All humanity except our time has understood that. The appeal to the eye is at once the most universal, and can be with the least expense of effort the most detailed. Our own time will probably suffer more through the neglect of this than through any other of our neglects, and posterity will ignore us most through our lack of pictorial symbol. It does not tell a future age anything to paint a picture of cows at a ford. It tells a future age very little to paint a picture of the ix 


\section{THE BAYEUX TAPESTRY}

Coronation, but to make a bas-relief of one policeman holding up one motor-bus, one man selling newspapers to one other man, and so on, all along a frieze, would be to leave a record of London, and a record which would be independent of the vitality of alphabets and idioms.

Now, this kind of record demands a Convention; in other words, it must be symbolic much more than it is mimetic, and that is the note you get in the work preserved at Bayeux. Not the reproduction of things seen, but the perpetuation of their ideas: a few figures standing for a host: an emblem defining a man : an episode noticed to its simplest terms.

Now as to the authenticity of, or to be more accurate the date of, this famous document. The more slipshod, earlier, and picturesque historians, with their touch of charlatanism and their eye upon the public (notably Freeman), naturally desired to believe, and even more naturally said, that the embroidery now preserved at Bayeux was exactly contemporary with the Conquest.

We must not include in our criticism or our blame such men as Napoleon, who, after all, did not pronounce himself, but took what he was told; nor men not professedly historians who carried on the tradition that the work came from the needle of William the Conqueror's wife and her ladies. An unhistorical statement proceeding from one who does not profess acquaintance with the bases of history cannot be seriously criticised. But, as the legend that the Bayeux embroidery is actually contemporary with the Invasion of England has been erected into a sort of University dogma and propagated through English schools and text-books, it is as well 


\section{INTRODUCTION}

to point out to my readers the nature of this simple error.

The Battle of Hastings was fought on the I $4^{\text {th }}$ of October Io66. The Bayeux Tapestry is later than the First Crusade, the climax of which campaign was the capture of Jerusalem on July I 5, 1099.

It is as certainly later than the First Crusade as a picture of a man in trousers and a top-hat is later than the French Revolution. How much later it is than the First Crusade we cannot yet say, and perhaps will never be able to say. We can say (just as we can say about the gentleman in the trousers and the top-hat) that it is quite appreciably later than the turning-point in history chosen for our fixed date of change. It was the French Revolution which disturbed, woke up, rearranged society. Attaching to that big business any number of external expressions may be discoveredquasi-democratic parliaments, the modern post-office, conscript armies, \&c. \&c., but the historical date is I789-I795. One of the products or marks of the change is the change in costume. Even an expert in the distant future might be puzzled to tell you whether the engraving of a man in trousers and a top-hat was twenty or thirty or forty or fifty years later than 1795 . But he could be absolutely certain if a proper knowledge of the past had survived that it was some few years, say ten or fifteen years, or, even better, twenty years later than the conclusion of the Revolutionary upheaval.

Now, so it is with the Bayeux Tapestry and the First Crusade.

The dates of the First Crusade are Iog6-99. It was accomplished from thirty to thirty-three years after xi 


\section{THE BAYEUX TAPESTRY}

the Battle of Hastings. William was dead some time; men who, as boys, had deployed upon Telham Hill, and charged up the slope of battle were grizzled, were between fifty and sixty, when that squire from Sourdeval first leapt upon the wall of Jerusalem. But the effect or a great change, its external effect in habiliment and the rest, takes some few years to work, and early as we may put the Bayeux Tapestry, we cannot put it earlier than a date in which men who may in youth have seen the fight at Hastings were certainly old, even if they survived to give their testimony.

In rough figures, there must be an interval of at least fifty years. It is more probable that the interval was of greater length than that-but fifty years is the minimum.

Let me briefly lay before the reader the evidence upon which this decision must be accepted. I will enter into no one of the many-I had almost said innumerable-doubtful details. I will not even linger upon one part of the evidence, which is very strikingthe fact that the length of the Tapestry exactly coincides with the contour of the nave of Bayeux Cathedral, upon which it was annually hung. And my reason for not pressing this point is that we have no definite evidence upon the date of the nave of Bayeux. Let me make myself clear. We know, of course, that the Gothic is roughly the product of the Crusades. We know that the Romanesque is roughly the pre-Crusade architecture. A man has but to see the interior of Bayeux Cathedral (as I did at Mass three or four months ago during my inspection of this document) to see that that nave is a product of the Transition. But short of documents 


\section{INTRODUCTION}

telling us exactly when the ground plan of the nave was drawn up, we cannot establish a date within fifty years. What adds to our ignorance is the fact that your later work was nearly always and throughout Europe modelled upon your earlier work. Consider, for instance, all the discussion with regard to the extension of the western end of Chartres; or consider the massive Romanesque foundation and pillars of Notre Dame in Paris, with its Gothic superstructure ; consider the accident by which we owe the Gothic unity of that monument to the fire which happened to destroy in 12 I 8 the original Romanesque apse. Had evidence of dates not survived in the case of Notre Dame we might be out by anything between fifty and seventy years.

So with Bayeux. The correspondence of the length of the Tapestry to the length of the nave proves that the Tapestry was at least not earlier than the nave, but we do not know that the nave may not have been of just that length before some process of rebuilding.

No; the evidence that the Bayeux Tapestry is later than the Battle of Hastings and the reign of William the Conqueror is of a simpler and more conclusive kind, and resides in the idea the artist had of men's accoutrements -dress and arms.

Let me detail these.

First, Edward the Confessor bears a crown marked by the fleur-de-lis. Now the fleur-de-lis thus marked upon the crown is a matter of the twelfth century, not of the eleventh-just as is the oriflamme. The sceptre, if we may judge by the seals and manuscripts (which with very rare sculptural examples are our sole evidence), is a xiii 


\section{THE BAYEUX TAPESTRY}

twelfth century and not an eleventh century sceptre. This note on costume is true even down to the details of the shoes upon the feet; they are the shoes of the middle of the twelfth, not of the end of the eleventh century.

Now turn to something upon a larger line, though not more conclusive : the adornment of the shield.

I am here upon very vague ground, and I know it. But I think that ground, though vague, has limits inferior and superior. The custom of adorning the shield with distinctive marks which might be recognised in battle, is of course as old as the world-or at least as old as the profession of arms. But something ritual and regular attaching to this habit, something which made it part of society and a wheel within the machinery almost of law and certainly of social habit, is the creation of the Crusades.

A modern parallel will make my point clear. A cheque is something belonging to the nineteenth century, especially the latter part of the nineteenth century. Orders for payments signed in various ways are very much older. But a cheque is a cheque. It is something crystallised and developed in what is now a fixed and a final form. So with armorial bearings. Bring me some new document which shows that Charlemagne himself had the sun or the moon painted upon his shield, and I shall not be surprised; but I do know that the regular portraiture of such and such emblems to represent such and such people, and the common habit among great families of always having such, is posterior to and not prior to the Crusading march: it was indeed, in the main, a product of the Crusading march. 


\section{INTRODUCTION}

Now, the Bayeux Tapestry, though it shows us most of the shields without such signs (for most of them were the shields of common knights), yet shows the shields of leaders regularly adorned with distinctive bearings; note, for instance, the four lords who come from Guy of Ponthieu to take Harold prisoner. Each of these shields carries an armorial bearing. The two heralds or messengers, men presumably of position, who ride to tell William the overlord that Guy has captured Harold, are similarly distinguished. Those in the immediate suite of the sovereigns or quasi-sovereigns show the mark, as when Harold is interviewed by William. One principal shield is hung upon the first two ships of those which sail for England for the Conquest, and each has armorial bearings. Nor need the reader be surprised at the number of shields which have none, if he will consider how large a proportion are seen in reverse-that is, from the inside-the side where the shield was held by the arm, the side which was turned towards the body. For where the artist describing a fight shows us the right arm with its weapon, and therefore the left arm holding the shield from within, he cannot let us know whether the shield was ornamented or no. But turn to the scenes where the fight is upon the defensive, as, for instance, that showing Harold's resistance to the Norman charge, there you at once get the leaders with their pictured shields marking the distinction of rank; or again, where the Norman charge in the next panel is shown getting home into the Saxon axes-there you have two shields out of five distinctively ornamented. In the episode of the death of the brothers of Harold, all the three shields that appear have some mark. There 


\section{THE BAYEUX TAPESTRY}

is no need to labour the point, nor even to point out the elaborate design upon one of the shields portrayed in the pursuit of the defeated army.

It is evident that we are dealing with a work produced at a time when it was thought normal that any man of distinction should carry his mark upon his shield, and, I repeat, to think that normal was the state of mind of the middle twelfth century at earliest and not of the mid-eleventh century at all.

There is just one good argument and only one for the contemporary character of the document; that argument is the argument from tradition. It is an argument to which I shall always offer the greatest reverence, particularly as it has been particularly despised by the superficial but popular University historians of the last century. Tradition is certainly the binding element in social memory, and if one could discover an active tradition that the embroidery of Bayeux had been made by the wives of those who fought at Hastings, though existing evidence not traditional would compel us to reject that tradition in its absolute form, yet it would be our duty to consider closely how the tradition arose and what it might mean-for instance, it might mean that the existing work was the adaptation of an earlier work. But, as a fact, the tradition is not old. It was not of popular but of academic, and therefore of worthless, origin. The later Middle Ages seem to have known nothing of it ; the Chapter of the Cathedral, which was the conservator of the document, bears no testimony of the sort. To call the Bayeux Tapestry "Queen Matilda's Tapestry" seems to have been nothing but the guesswork of an antiquarian don. Let us leave it at that. 


\section{INTRODUCTION}

Another evidence of date is the fact (to which I shall make continual allusion in the text) that the Bayeux Tapestry follows fairly closely the Roman de Rou, Wace's poem describing the Conquest; and that poem cannot be earlier than the middle of the twelfth century-it is usually put as late as the last third of the twelfth. Not only is Wace followed, but certain other authorities which help to date the production.

Now this would be quite conclusive but for one rebutting argument, the value of which I leave to the judgment of the reader. The written sources which the Tapestry appears to follow would repose upon certain common traditions, memories, and earlier documents, and the Tapestry might be imagined to repose upon the same. But the general rule in tracing the sources of human work of this sort is that the written account precedes the pictorial and serves as a basis for it, while the convergence of this evidence with the evidence of accoutrements and dress leaves little doubt.

We have in the Bayeux Tapestry something certainly later than I I 40, ${ }^{1}$ almost certainly later than I 50 , pro-

1 The bier of Edward the Confessor is designed in the twelfth century fashion, not in the eleventh-the long vestment of the royal personages throughout is a twelfth century not an eleventh century type. The description of the coat of mail in Wace (verses 6522 and the following) is that of the Tapestry; and most important of all the coat of mail of the Tapestry is no longer the mere breastplate, but the full coat of the Crusading period.

It is true that we have very little information upon the eleventh century armour, but with the Crusades we do get a full description, and we have a right to judge by what we know rather than by what we do not know. Thus Ordericus Vitalis remarks the full coat as a novelty.

The helmet with a nasal is not now in any document before the xvii 


\section{THE BAYEUX TAPESTRY}

bably as late as I I60, but, on the other hand, certainly prior to the date 1200.

seal of Baldwin, the late III5, but after that date it is common, as one may see in the seal of Charles of Flanders or of Matthew of Montmorency. Indeed, the seal of William the Conqueror himself gives no sign of the nasal, and the same is true of the seals of the First Crusade. This kind of helmet is wholly twelfth century; but remark that William, in the Chronicles, lifted his helmet to show his face. So there is here doubt. 


\section{NOTES}

The corresponding reference-numbers will be found in the following text.

1 Many of our historians carelessly talk of Harold being brought to Rouen. We have no proof of this. There is just one allusion in the Chronicles to the place where delivery of Harold's body was made from Guy to William, and the place mentioned is what we should expect, a frontier town, Eu. The Palatium does not only mean a place, it also means an institution; and though Rouen was William's chief city, whenever he moved, his clerks and staff of government-that is, his "Palatium"-moved with him.

$2 \mathrm{Mr}$. Oman in his version of the affair makes Bonneville the scene of the oath. I have not seen the proof of this. The two fundamental pieces of evidence -Wace and the Tapestry-both say Bayeux. William had a castle above the river Touques at Bonneville, and ruins of it, or of a later construction upon its site, can be seen to-day; but it is a good two days' march from Bayeux.

The French word "parliament" meant, of course, any general assembly for discussion, and was here used of something earlier than any representative assembly, though these were already springing up in the Spanish March of the Pyrenees, to which district we owe the origin of representative institutions.

3 I have never understood why this third messenger should have been confused with Harold himself. The Latin inscription is quite clear: "Here they gave to Harold the Crown of King." The people holding the axes are not Harold, neither is the man offering the crown, that 1 can see.

"The Tapestry, of course, does not show Freeman's famous "Palisade," and that for an excellent reason. The Palisade never existed outside the imagination of Oxford. 


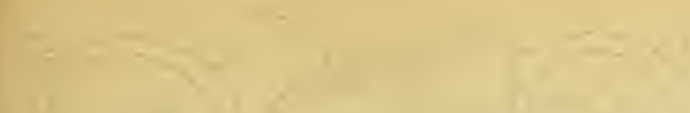

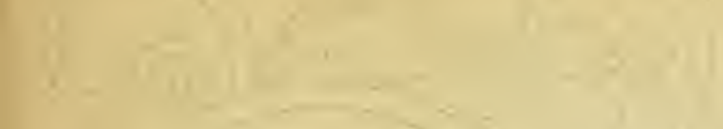

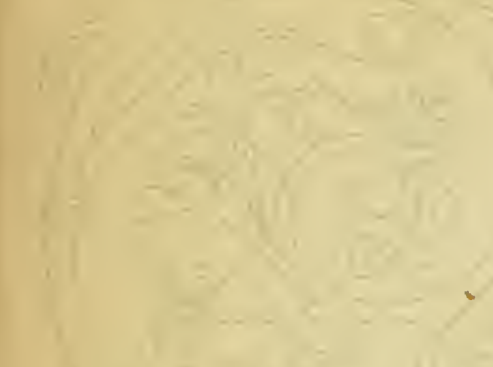

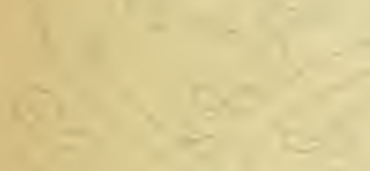

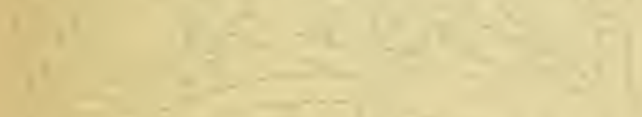

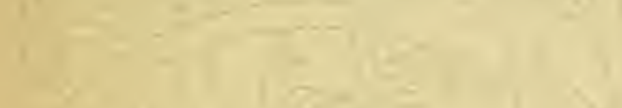

$\frac{1}{1+1}+10$

$x=1$

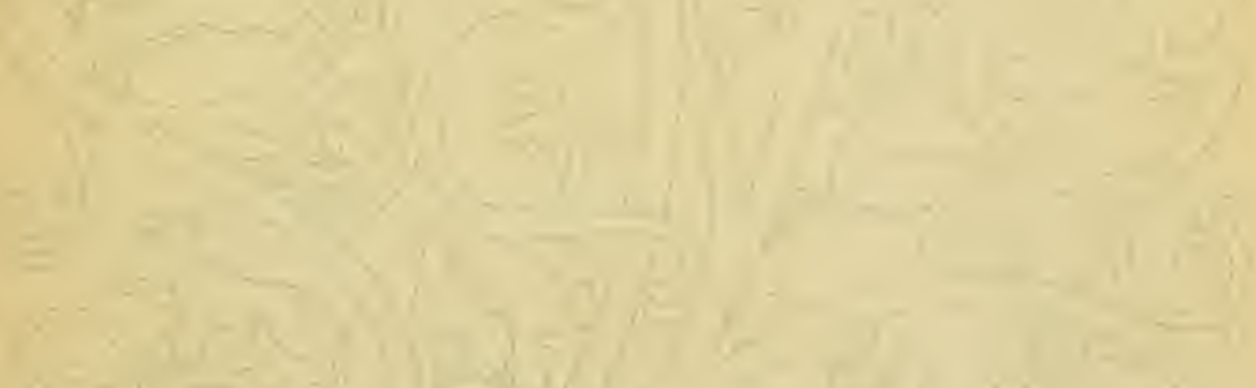

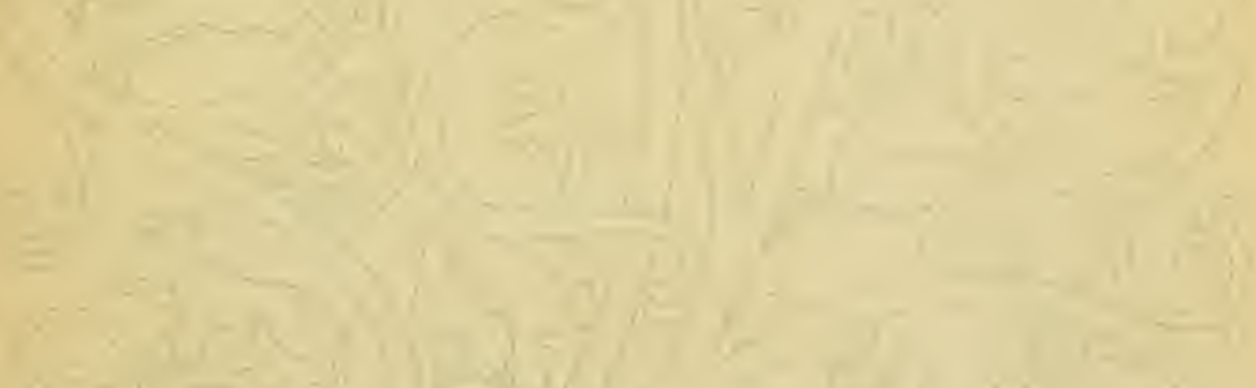

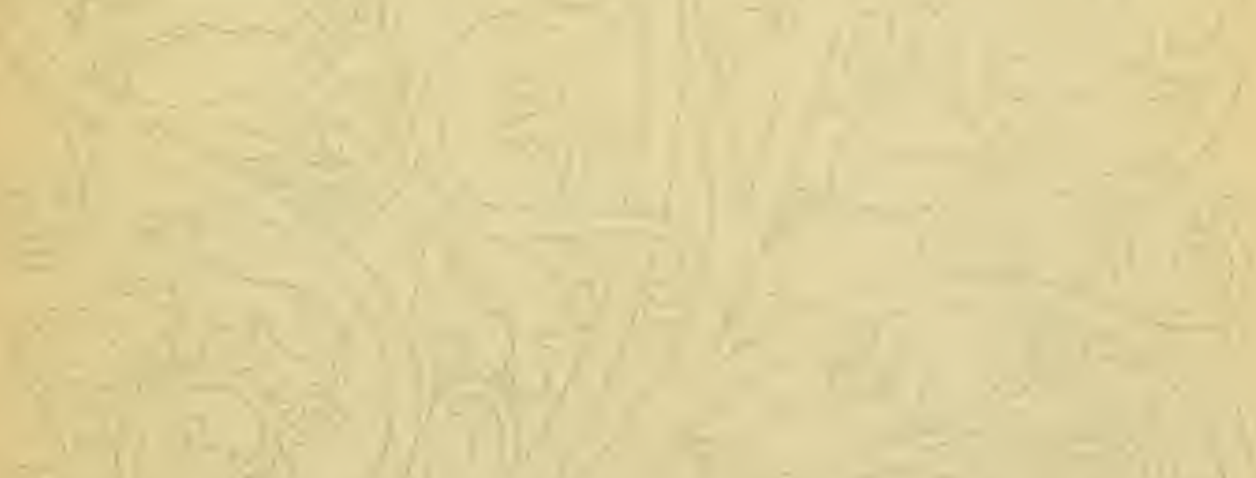

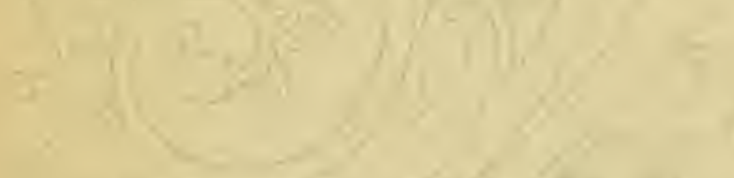

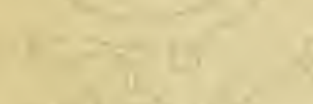

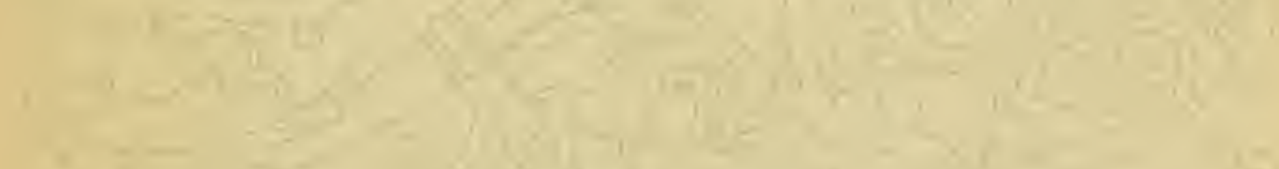

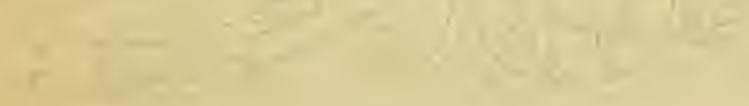




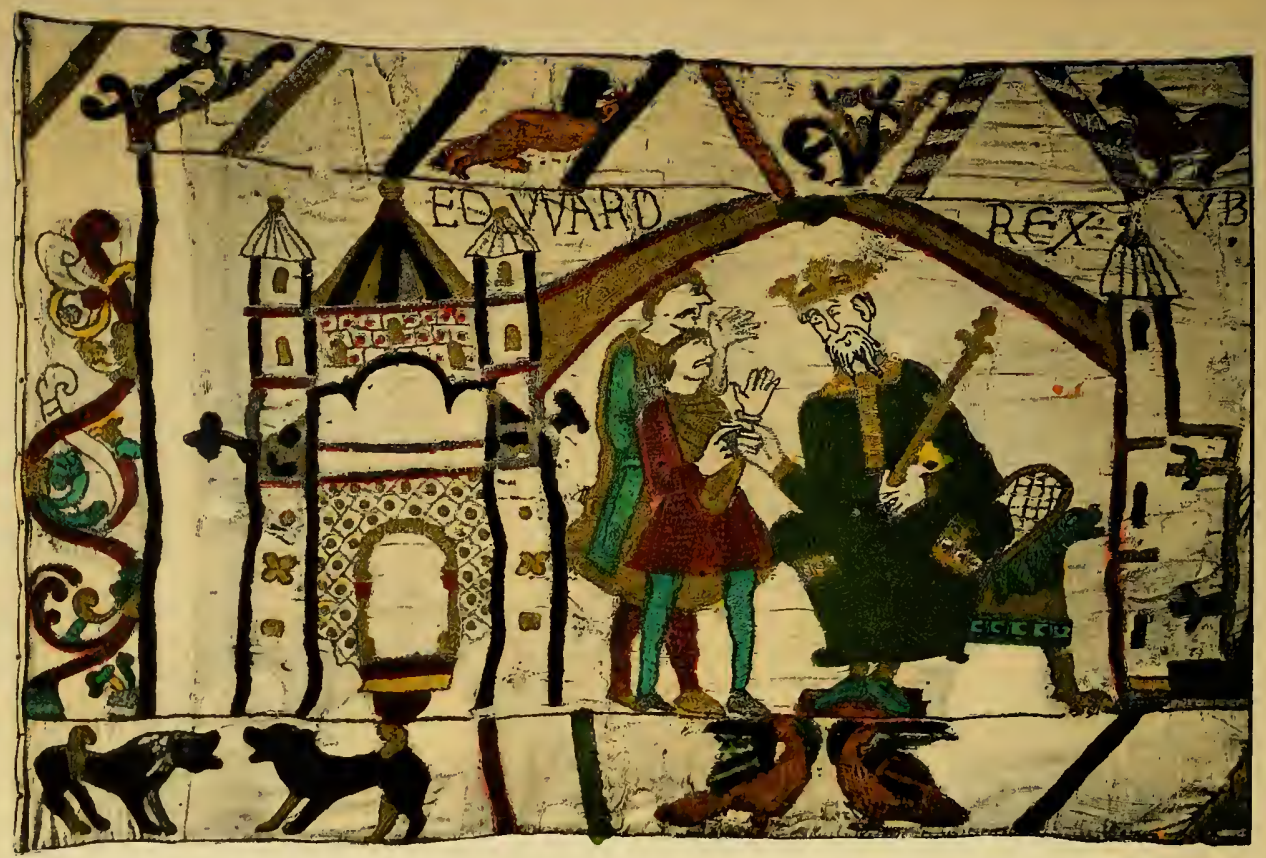

THE first three sections of the Bayeux Tapestry must be taken together, for they describe one incident, which is the departure of Harold from Bosham, the port of Chichester, and a manor of his own. Of strictly contemporary evidence to that journey we have none. We can only guess that the year in which it was taken was the year 1064. As to its motive the Bayeux Tapestry gives of course the current Norman version, or rather hints at it. Edward the Confessor is in his palace at Westminster. It is important to note the conventional signs of his rank, the sceptre and the crown. It is the reappearance of the same symbols in the crowning of Harold-which was in the Norman version his supreme act of treason-that is particularly insisted upon. Edward, thus officially presented as it were, is giving a message: that is certainly the symbolism of the attitude, and it is exceedingly likely, though

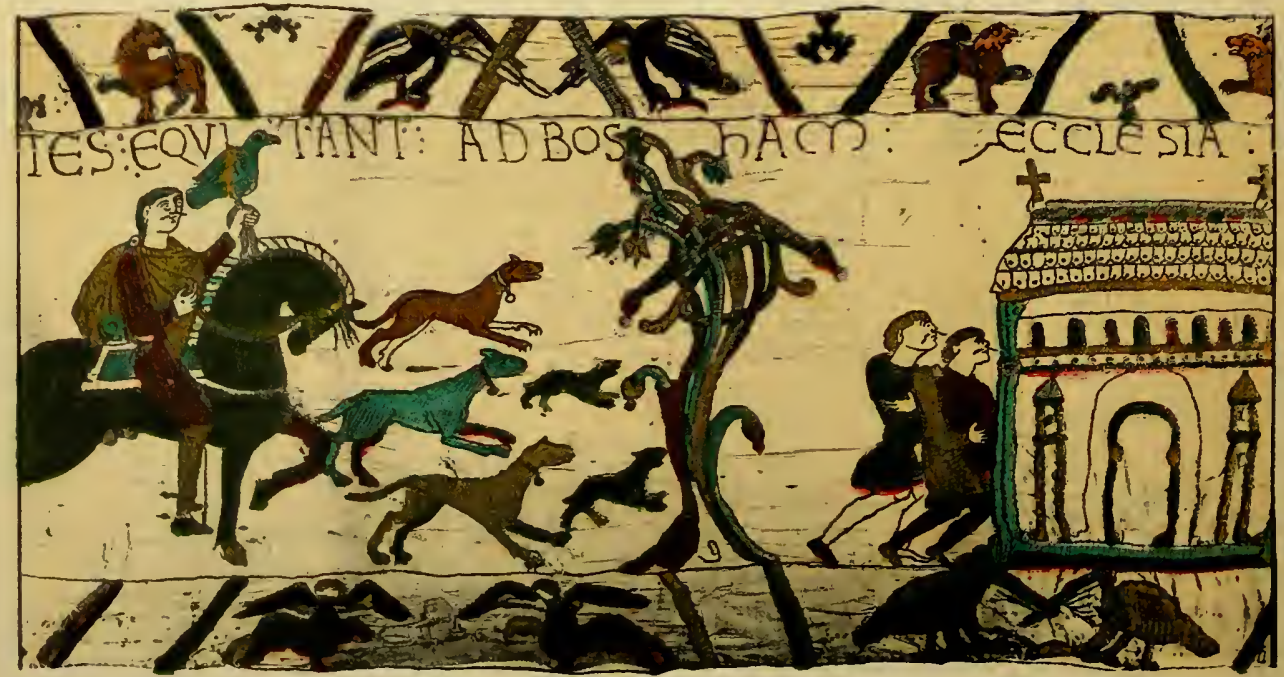




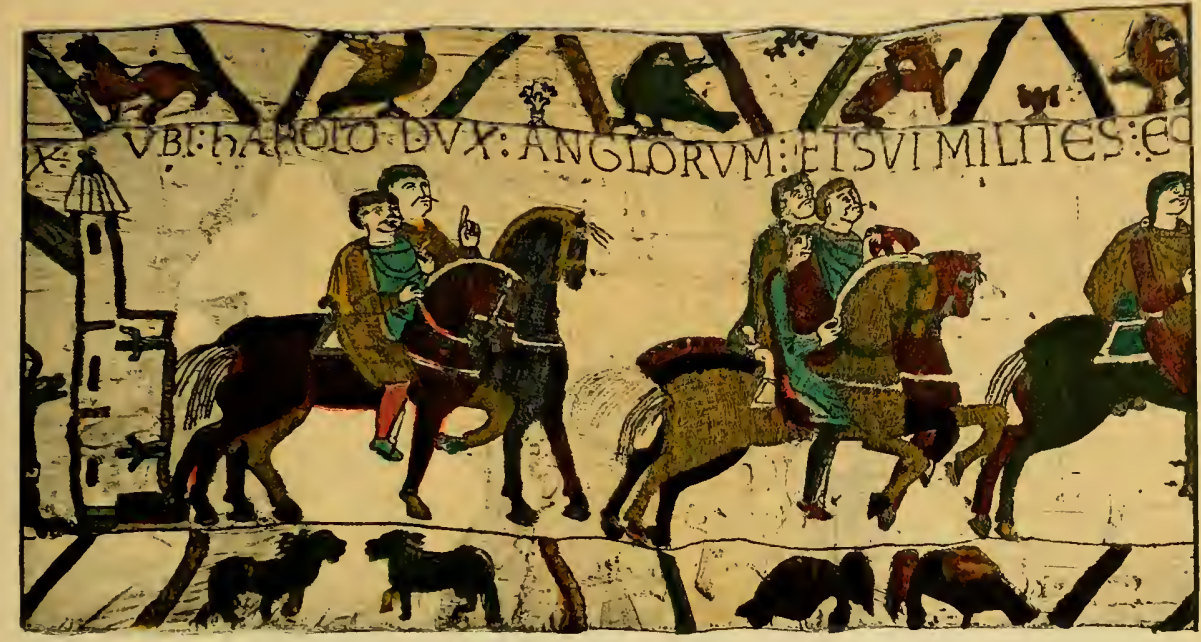

not equally certain, that the person to whom the message is being given is intended for Harold. But it is remarkable that the inscription here says nothing of the nature of that message, and that the point of capital importance -William of Malmesbury's assertion that Harold was sent by Edward to assure William of his succession to the English throne-is not set out. Taking Wace as the basis of the Tapestry-and this is the best hypothesisHarold sailed to release from William's custody his brother Wulfnoth, who had been kept as a hostage in Normandy for King Edward to guarantee King Edward the fidelity of Godwin. But we must remember that the Roman de Rou does mention Edward's sending Harold to assure William of the succession. And on the whole it is most likely that the intention of the Tapestry is to suggest this. Harold and his knights ride to Bosham. Harold himseif is conventionally distinguished by the hawk on the wrist. The Church of Bosham is introduced into the story probably or certainly with the object of emphasizing (as the Tapestry perpetually does) the religious enormity of Harold's later action, and both this visit to the Church and the Feast in the

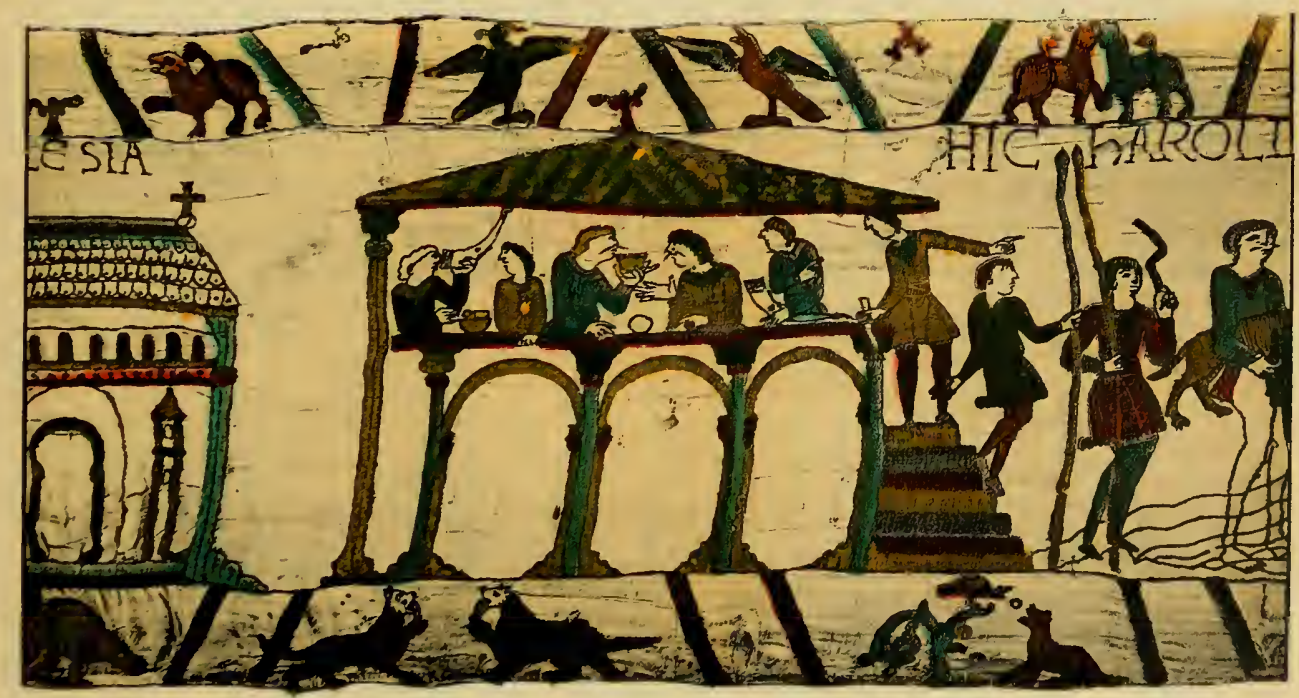




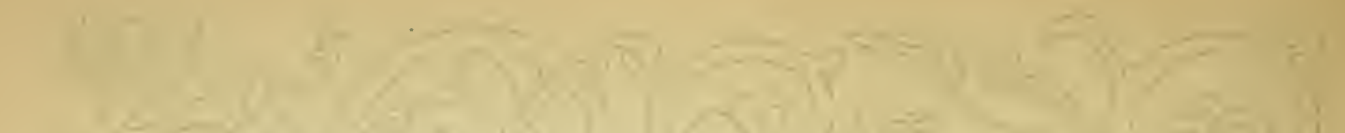

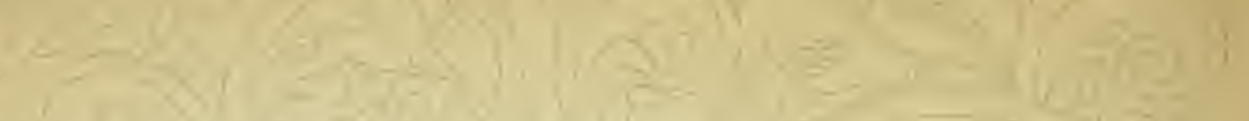

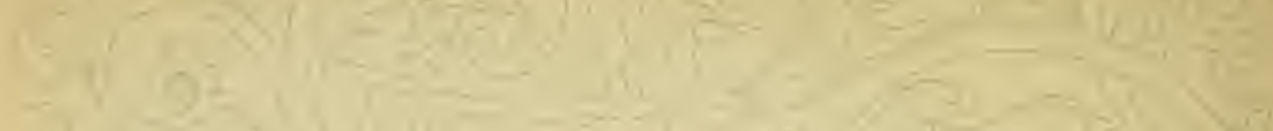

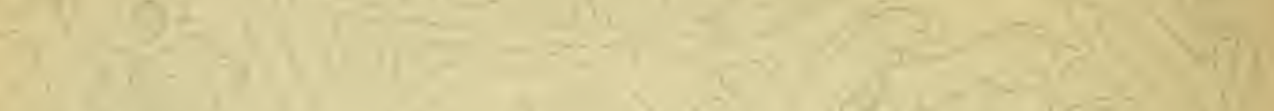

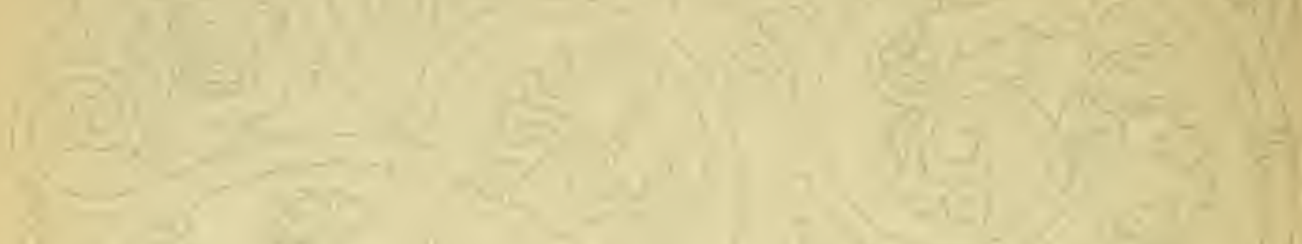

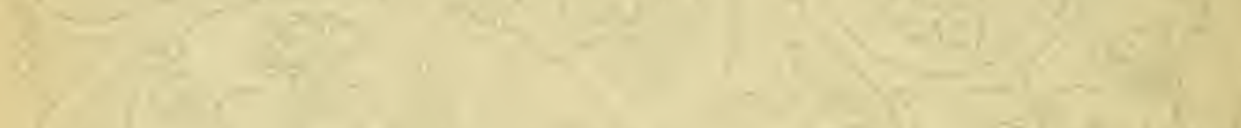

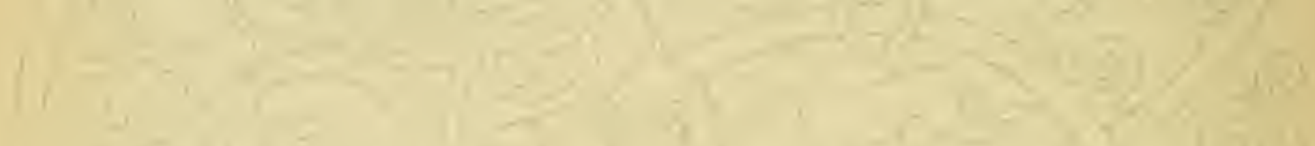

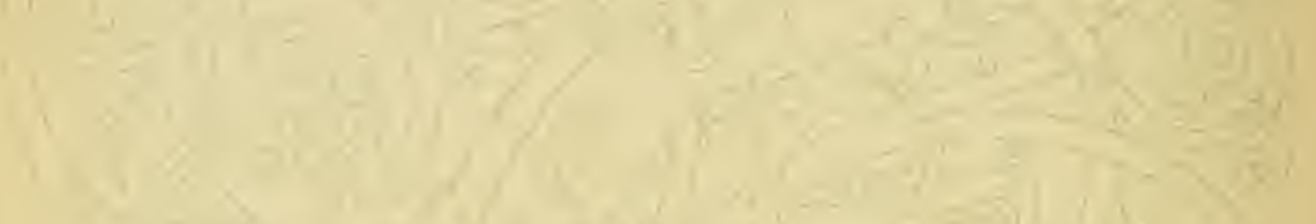

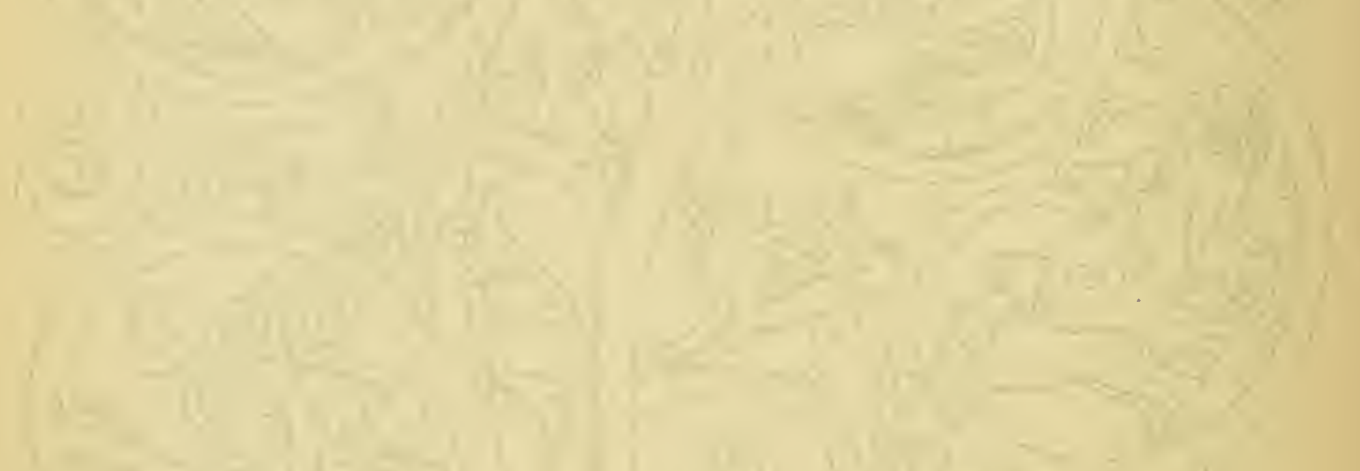

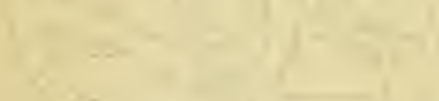<smiles>CC(C)C1(C)C2CCC21</smiles>

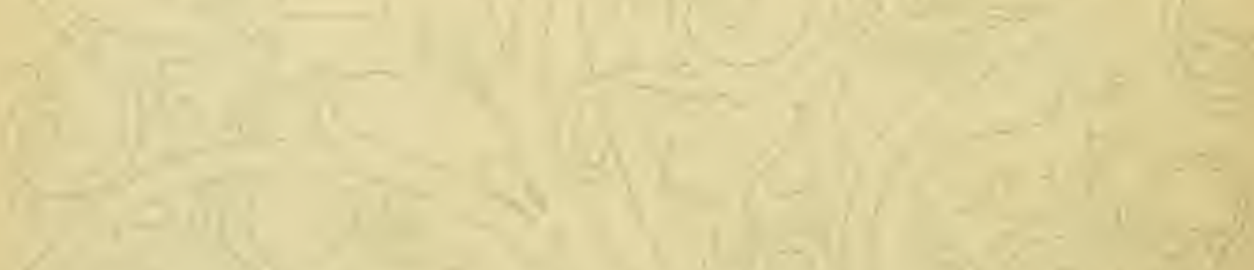

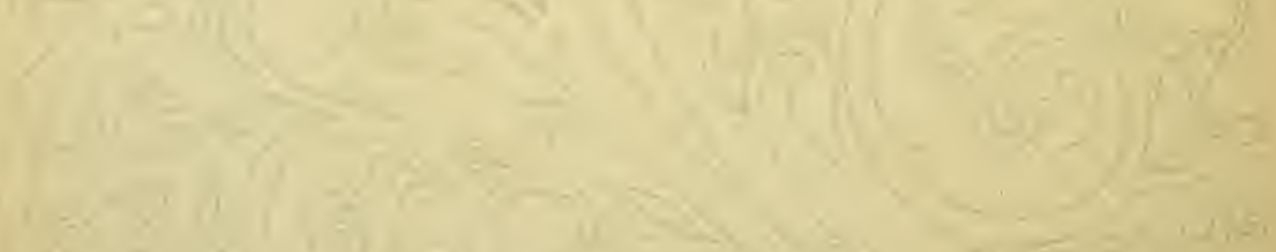

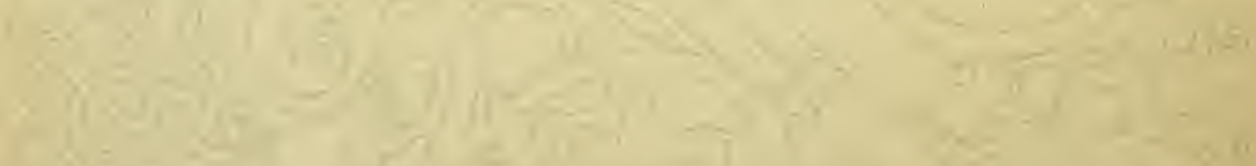

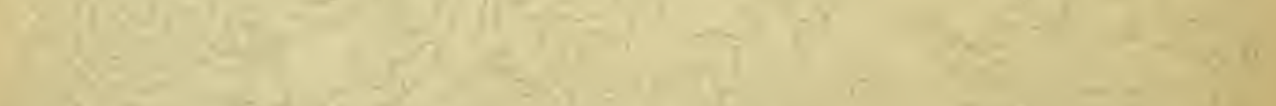

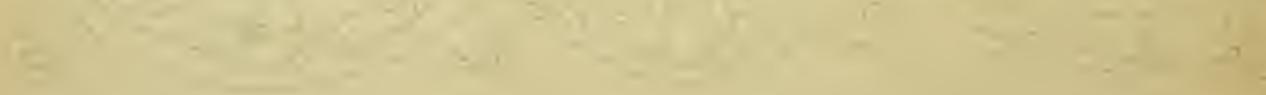


$y=-x-1=0$

2. -7

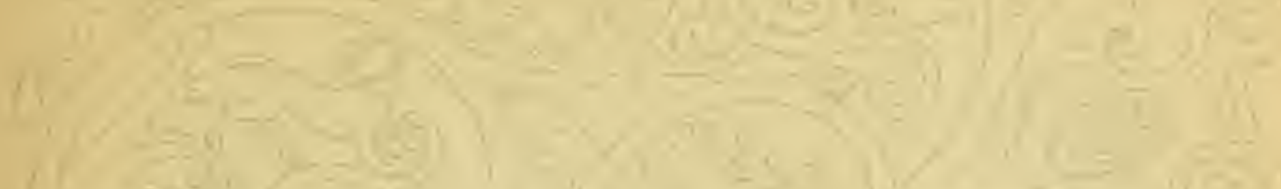

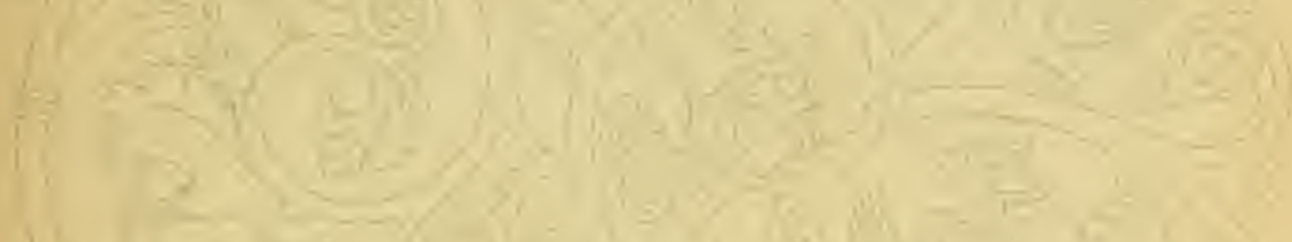

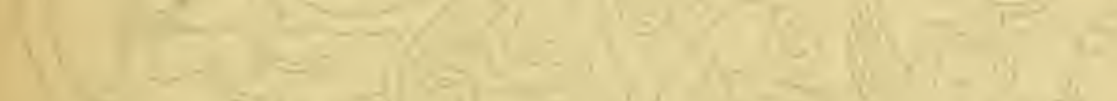

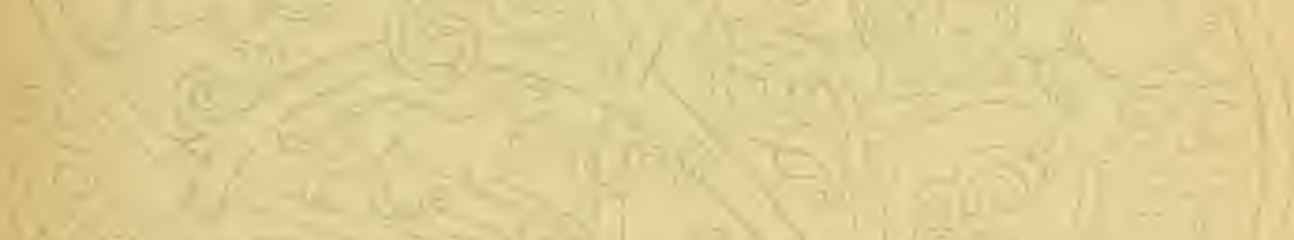

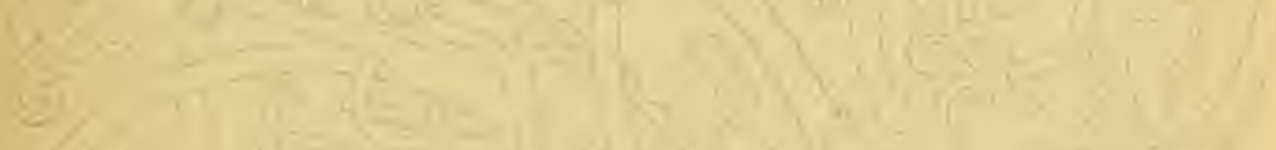

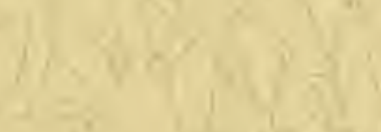

(y.

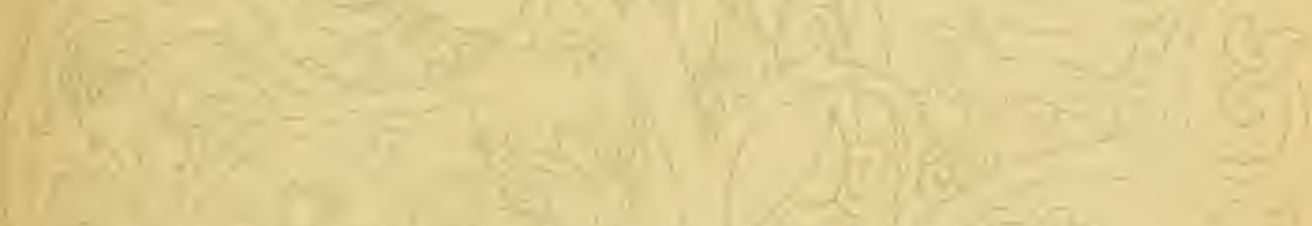

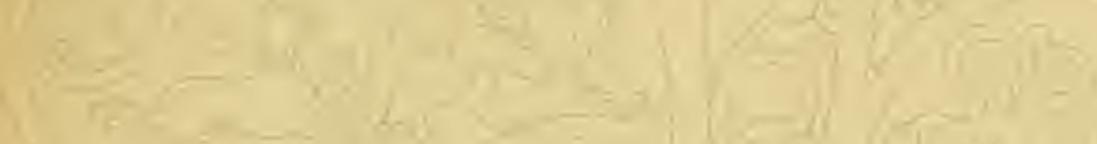

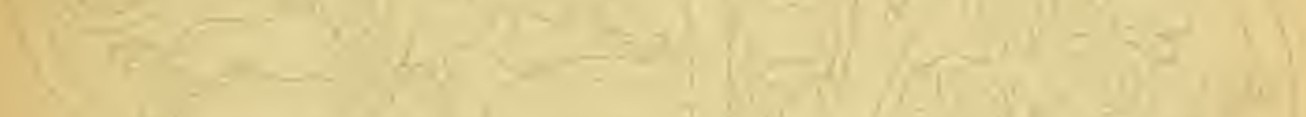

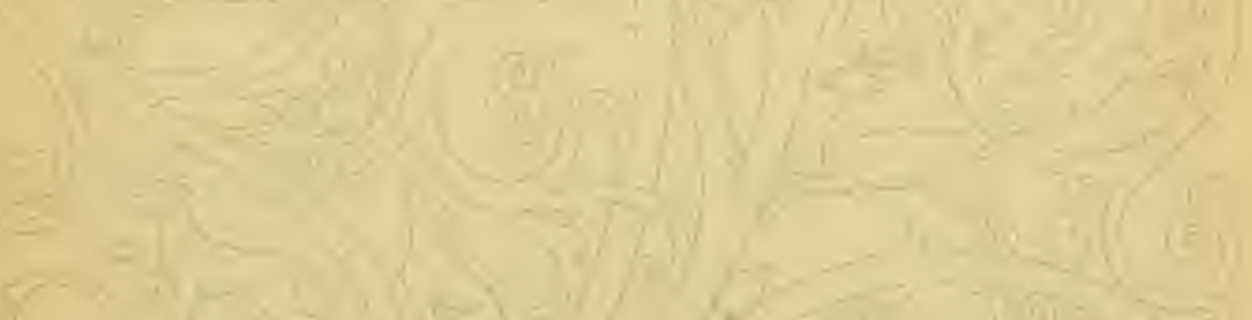

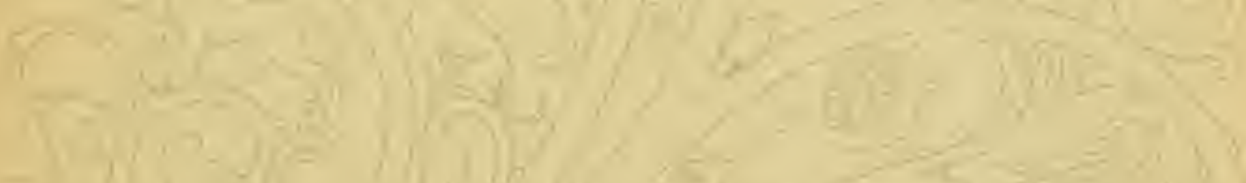

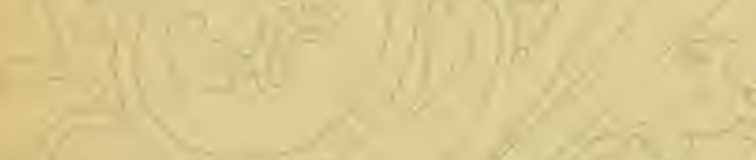

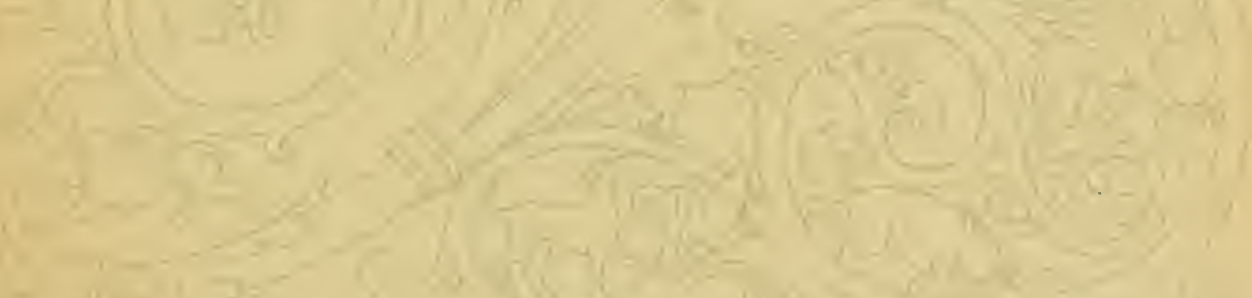

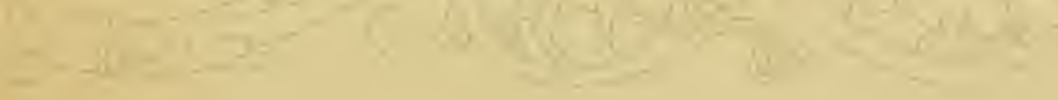




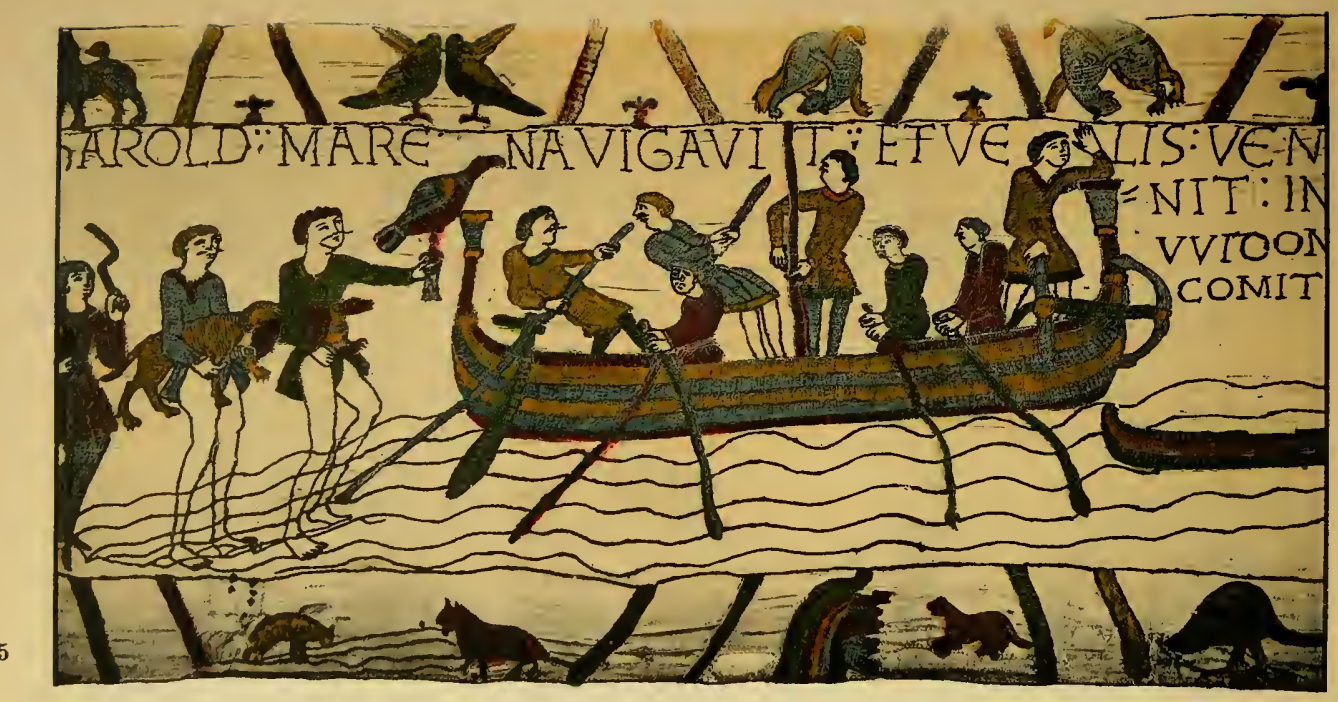

Upper Room before embarking, which forms the fourth episode, are clearly intended to refer to incidents which were traditional in the Norman story. But we have, I think, no remaining text giving either the visit to the Church or the Feast.

In the fifth division Harold and his suite embark, and it should be noted how large a company the Convention of the Tapestry supposes.

The intention of the expedition was almost certainly to make a Norman port. Once in the Channel the square-rigged ships could not beat into a wind that was too westerly for them or too much south of west, and their land-fall was at some point upon the coast of Ponthieu, of which district Count Guy was the lord. The point upon the coast of Ponthieu where the ships beached, or rather cast anchor in the shoal water, we may presume to have been the right bank of the estuary of the Somme, for it is the most convenient entry and has some shelter from a southerly wind; but all that flat

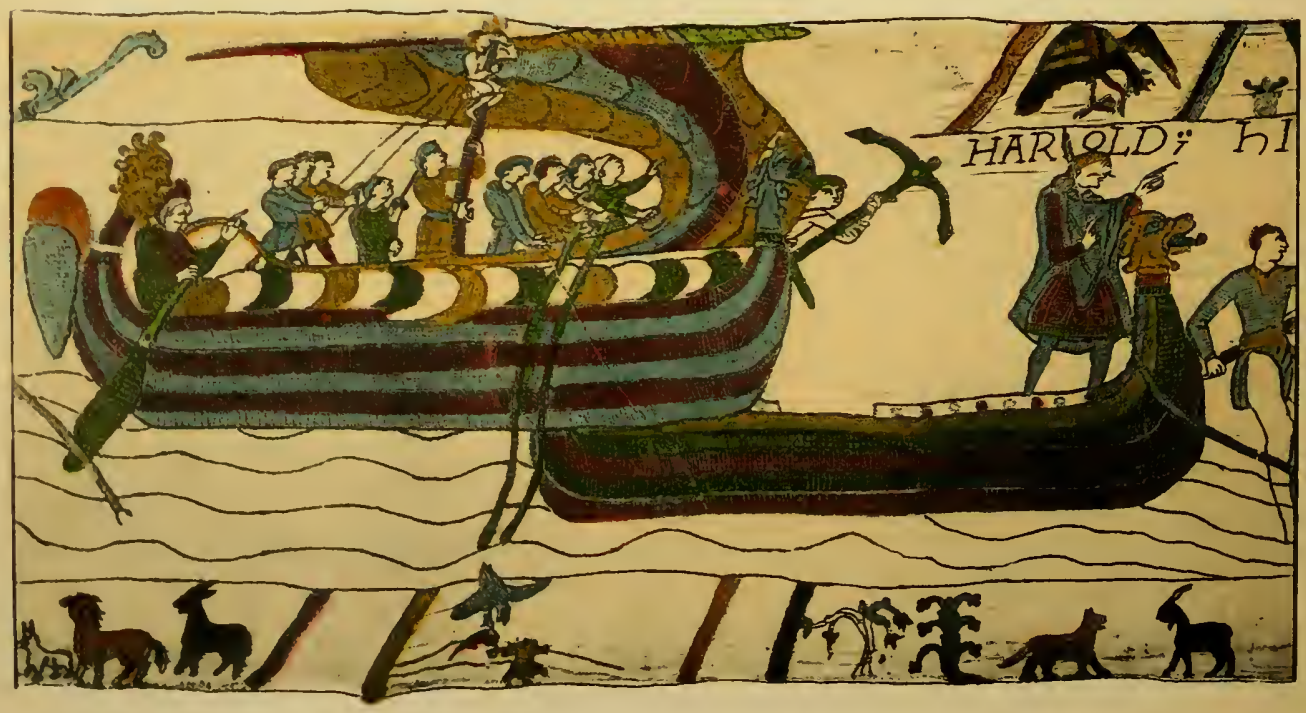




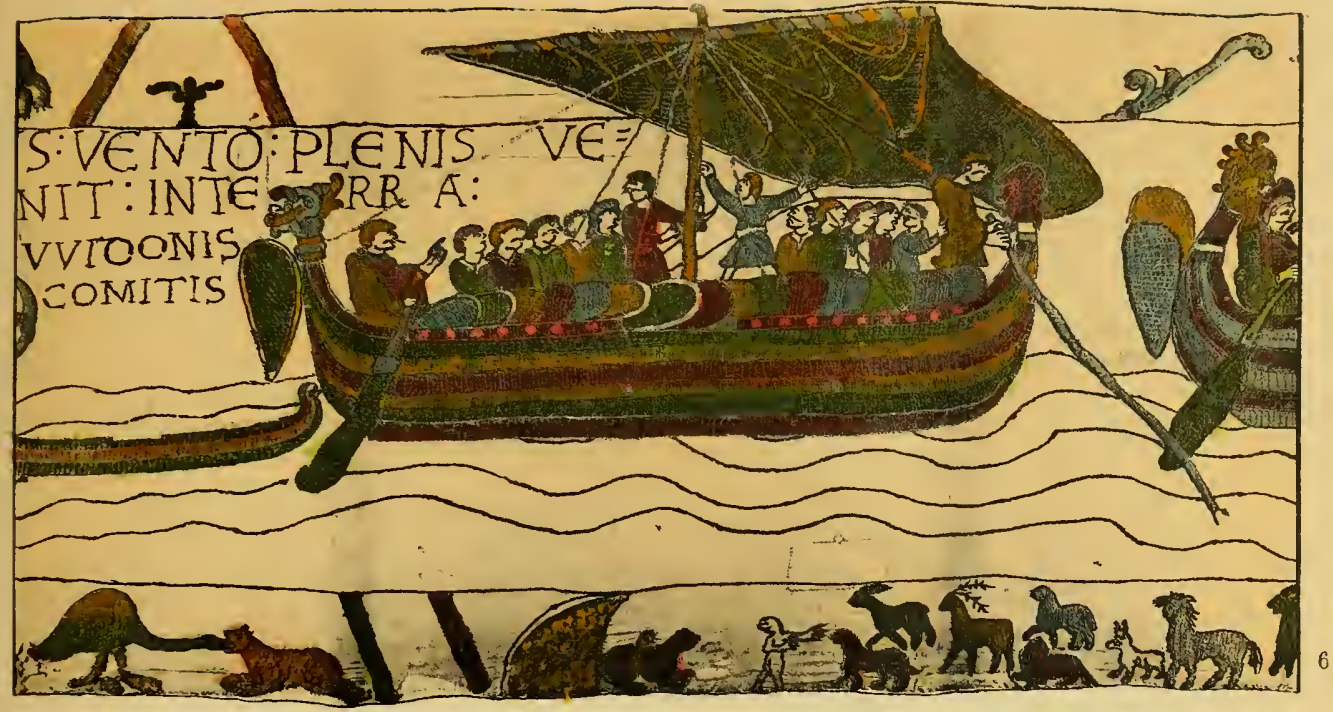

sandy coast gave good opportunity for landing from such vessels, and the fleet may have made the Bay of Authie or even the mouth of the Canche. But the choice is not a wide one, for the coast of Ponthieu did not extend beyond the Canche. If the Somme were the point of entry, it has this historical interest: that Harold would then have found himself fated to land at the very point from which William two years later was to sail for the invasion of England. Count Guy seized Harold for ransom, something of a formality, though a formality which was to be of formidable consequence. He takes Harold and his suite to "Belrem "- -the place to-day called Beaurain. Here the Tapestry follows Wace very closely, for it is Wace who tells us that Harold was recognised by a fisherman, who sent for Count Guy.

The capital of Ponthieu was Montreuil, and this castle of Beaurain, of which ruins still stand, was six or seven miles up the river from Montreuilone passes right beneath it in the railway to-day on one's way to Hesdin.

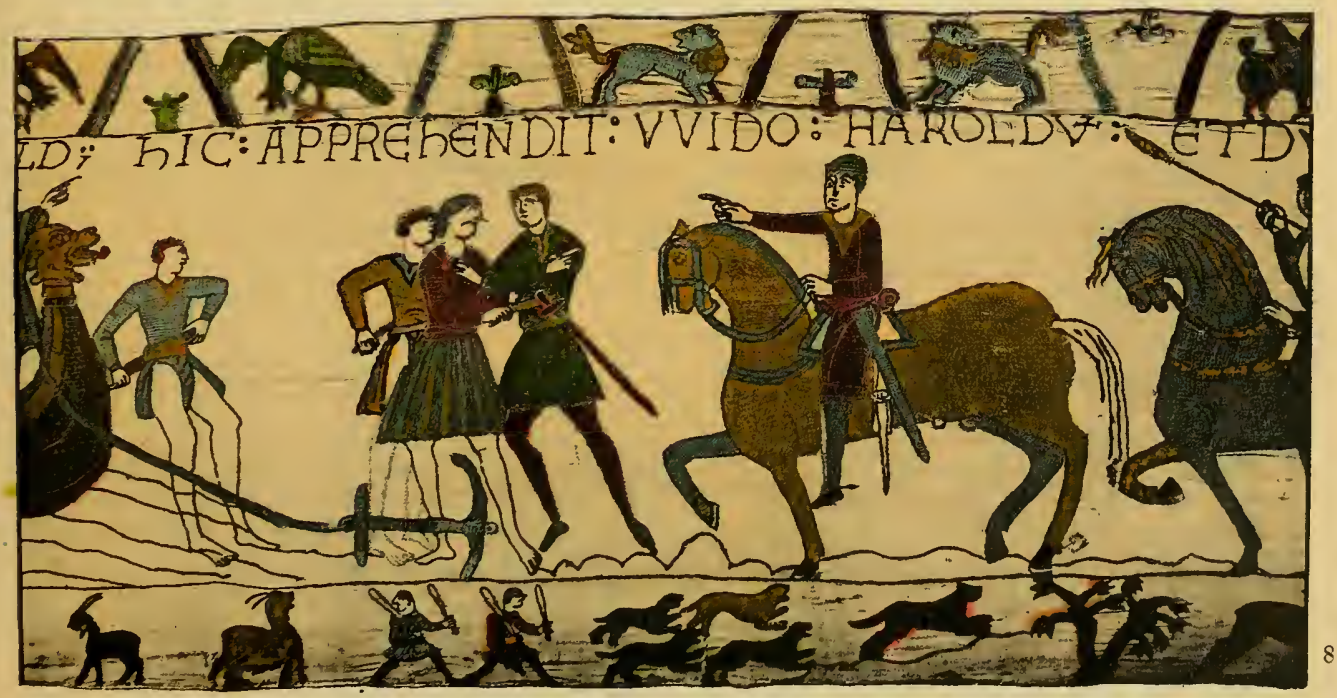




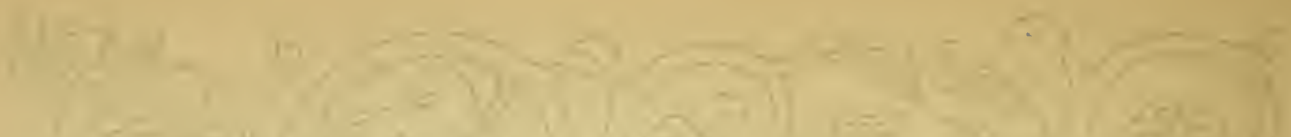

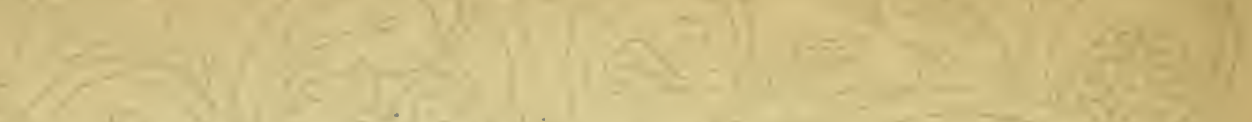

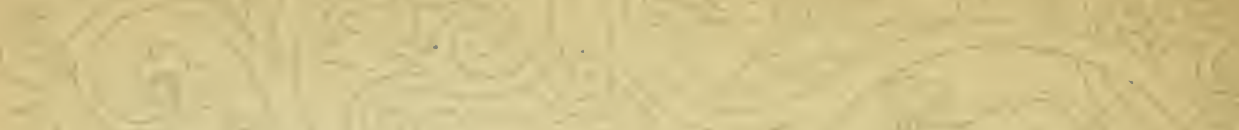

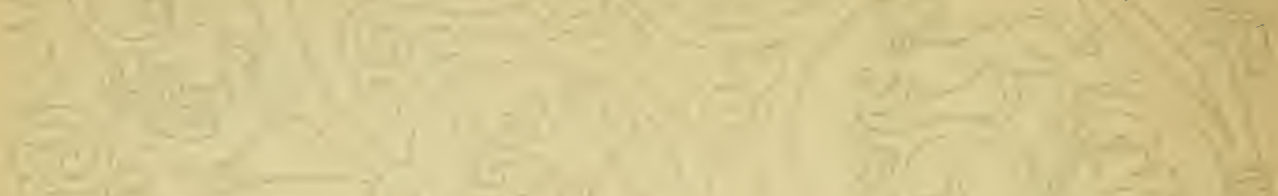

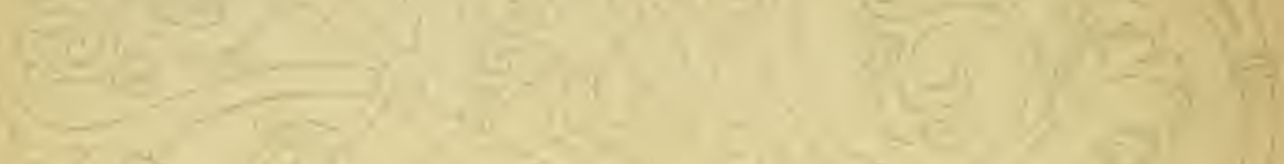

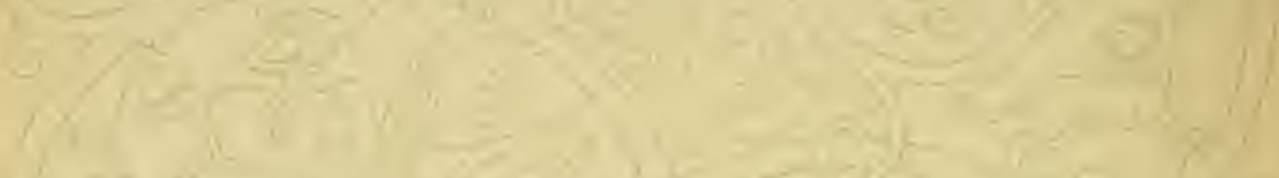

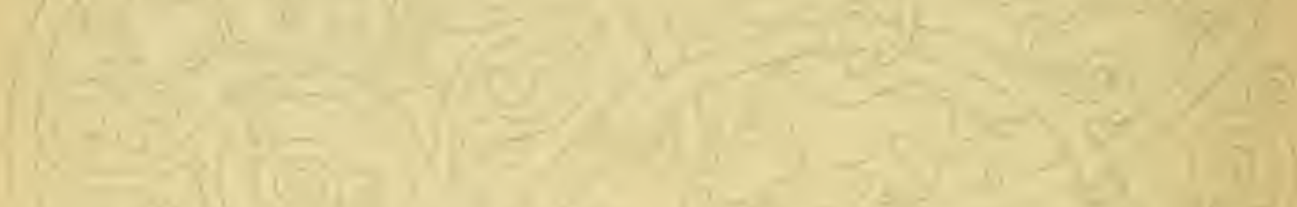

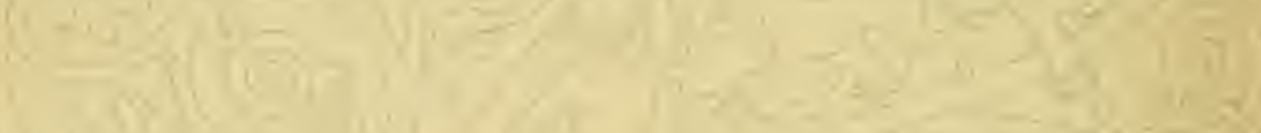

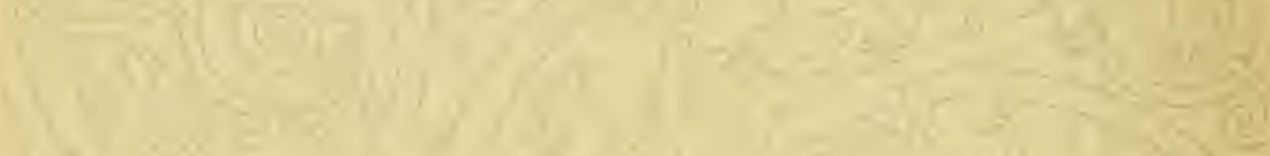

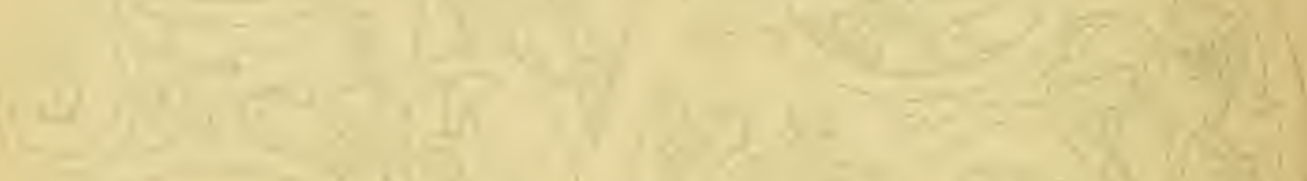

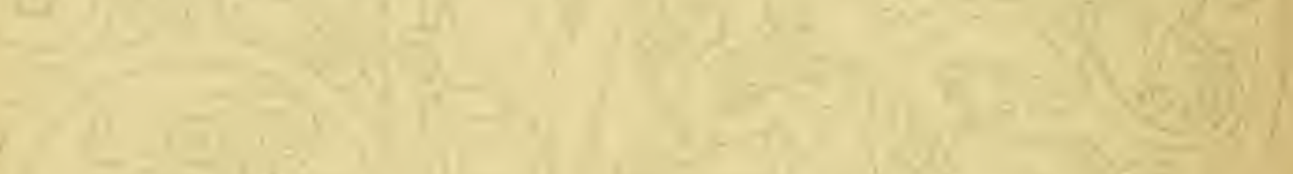

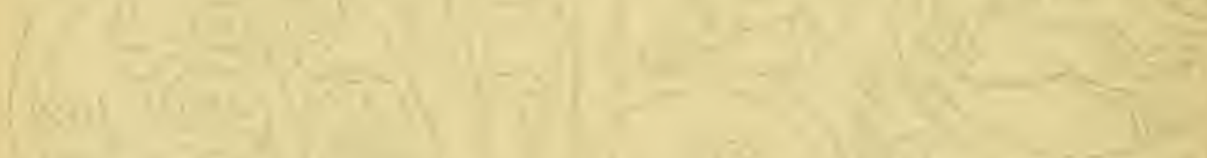

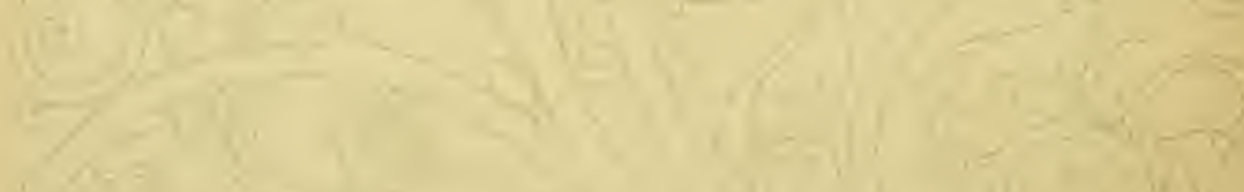




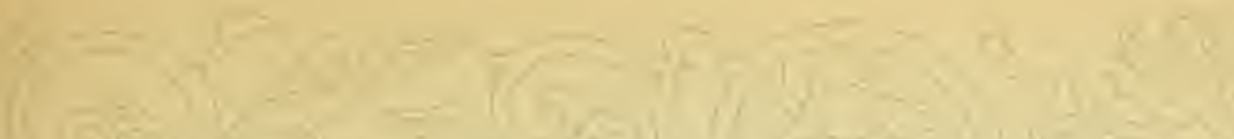

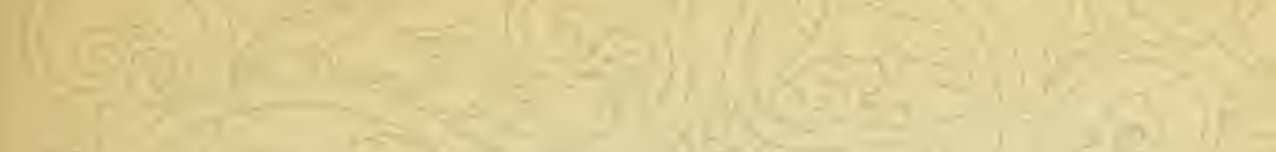

1

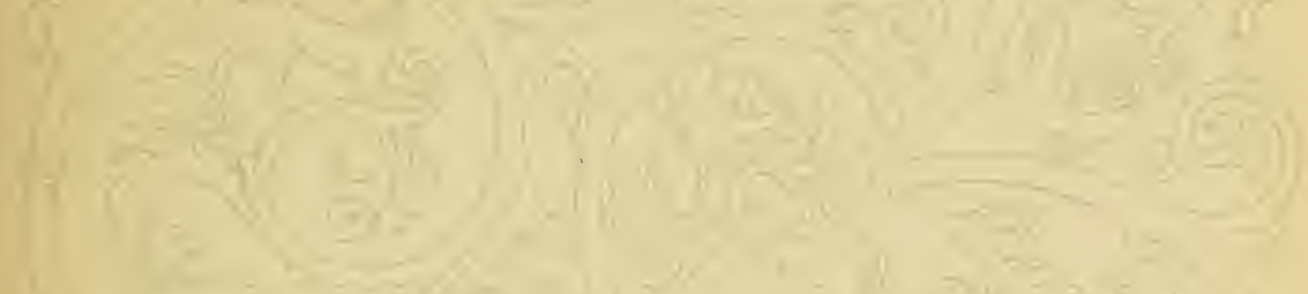
$2-1+1+2+2$ S. IL

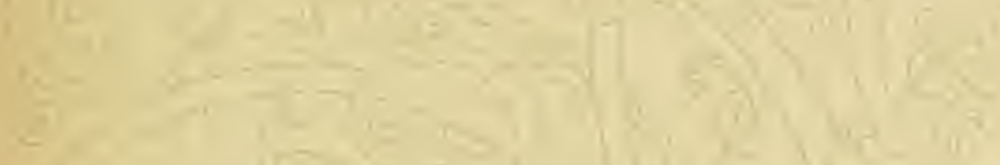

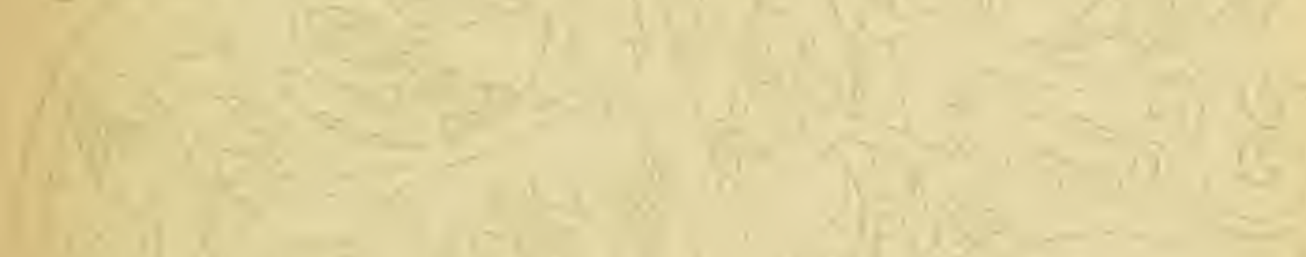
I

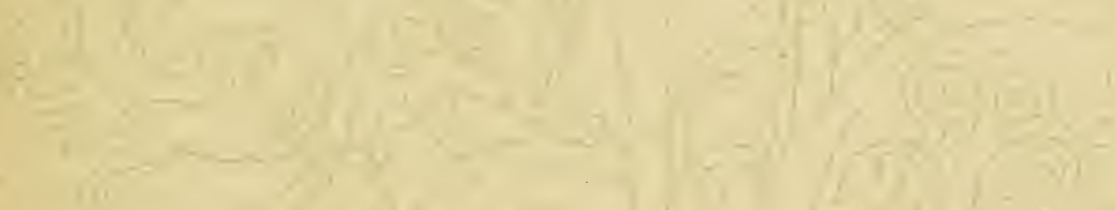

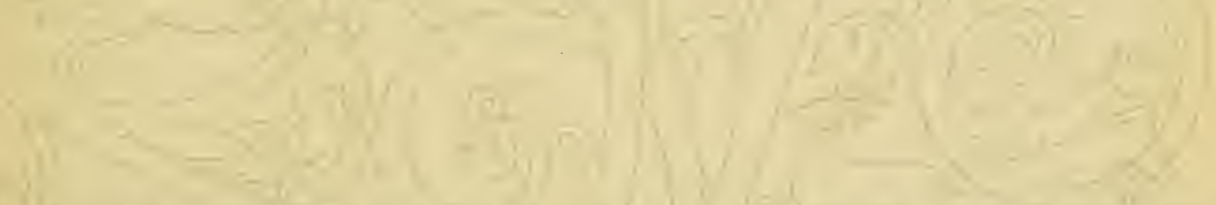
(1) r.

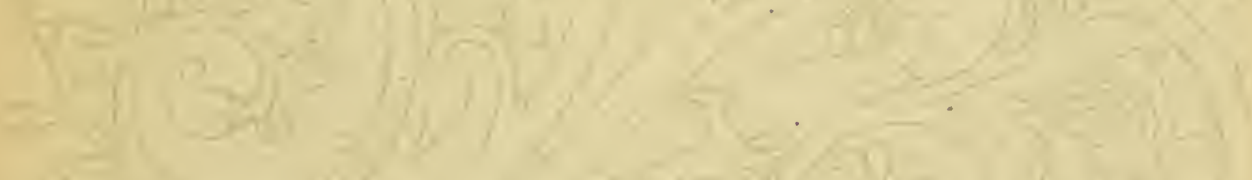
(16.

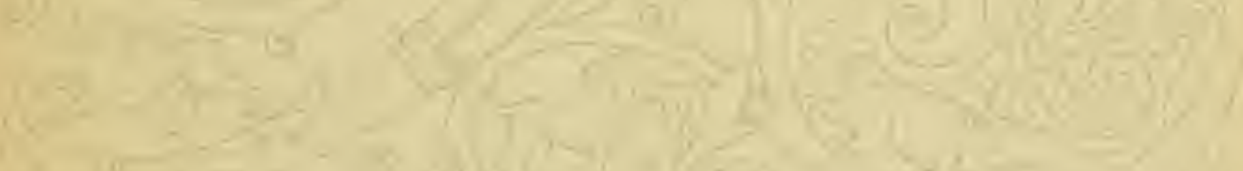

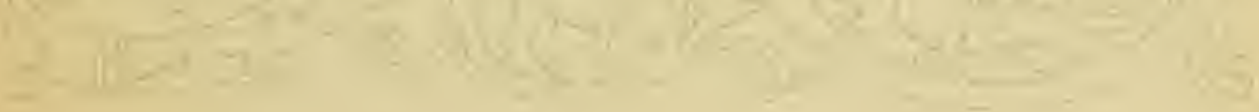




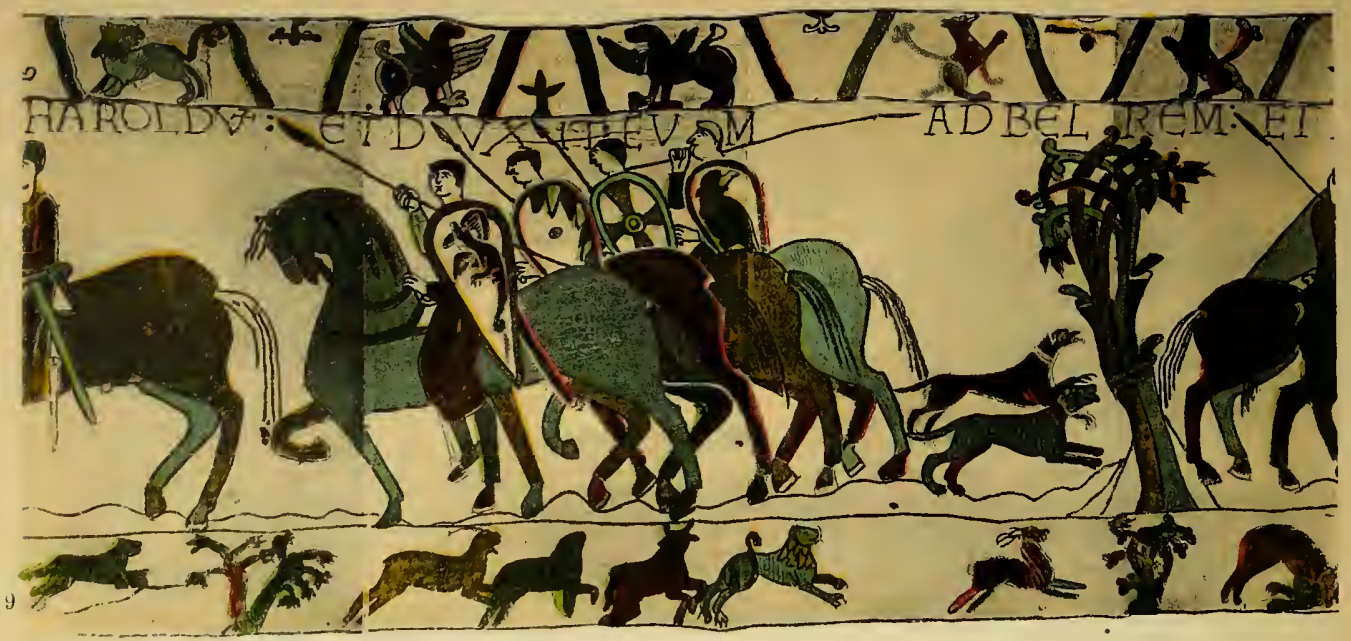

The last scene in this episode (which ends the first part of the story) is a scene by night in the hall of the castle of Beaurain, where by the light of torches Count Guy and Harold (who have ridden to Beaurain together as men of equal rank though one is being held to ransom) are bargaining-for the word "Parobolant" must refer to the discussion of the ransom.

To this first series of episodes in the story succeeds the arrival of the Duke of Normandy's heralds insisting upon the release of Harold because Guy was vassal to William. The advent of these messengers forms the $\mathrm{I} 2$ th and I $3^{\text {th }}$ sections of the design. It is perhaps a guide to the time of year in which all this took place, that on the border below we have the ploughing and the sowing of the spring. There has arisen in connection with these messengers of William's a considerable and rather futile debate as to the meaning of the little figure who is holding the horses. I take his small size to be merely a piece of perspective, and the word "Turold" to refer to the

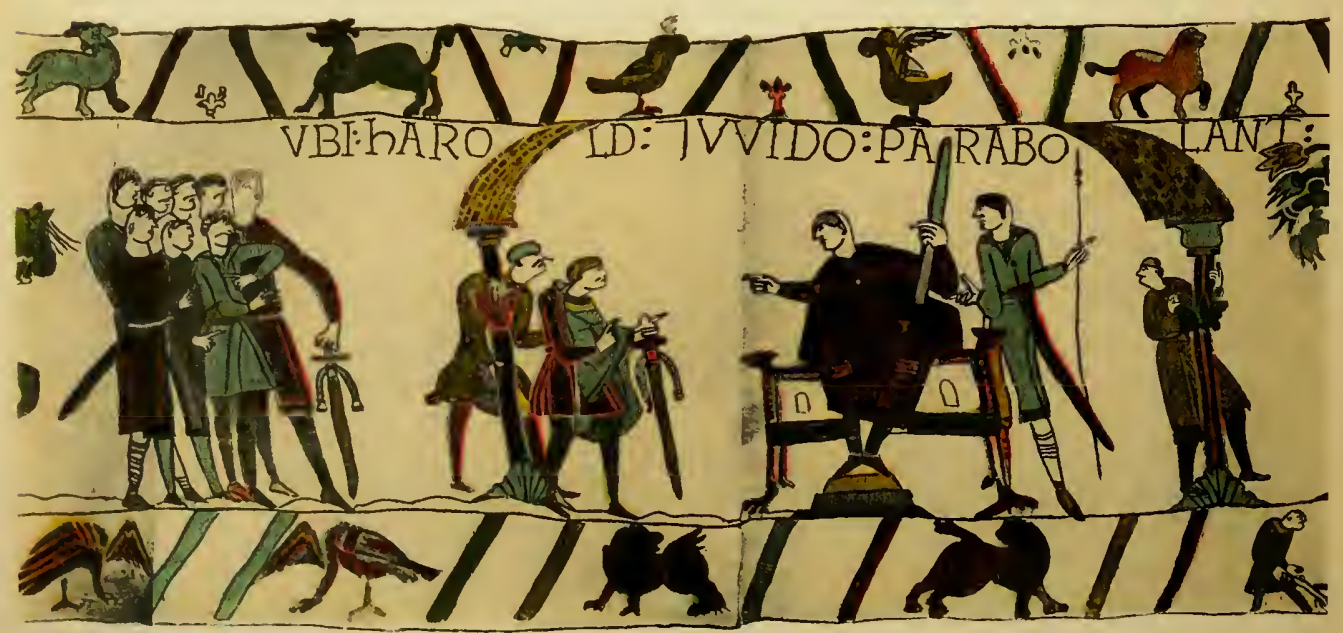




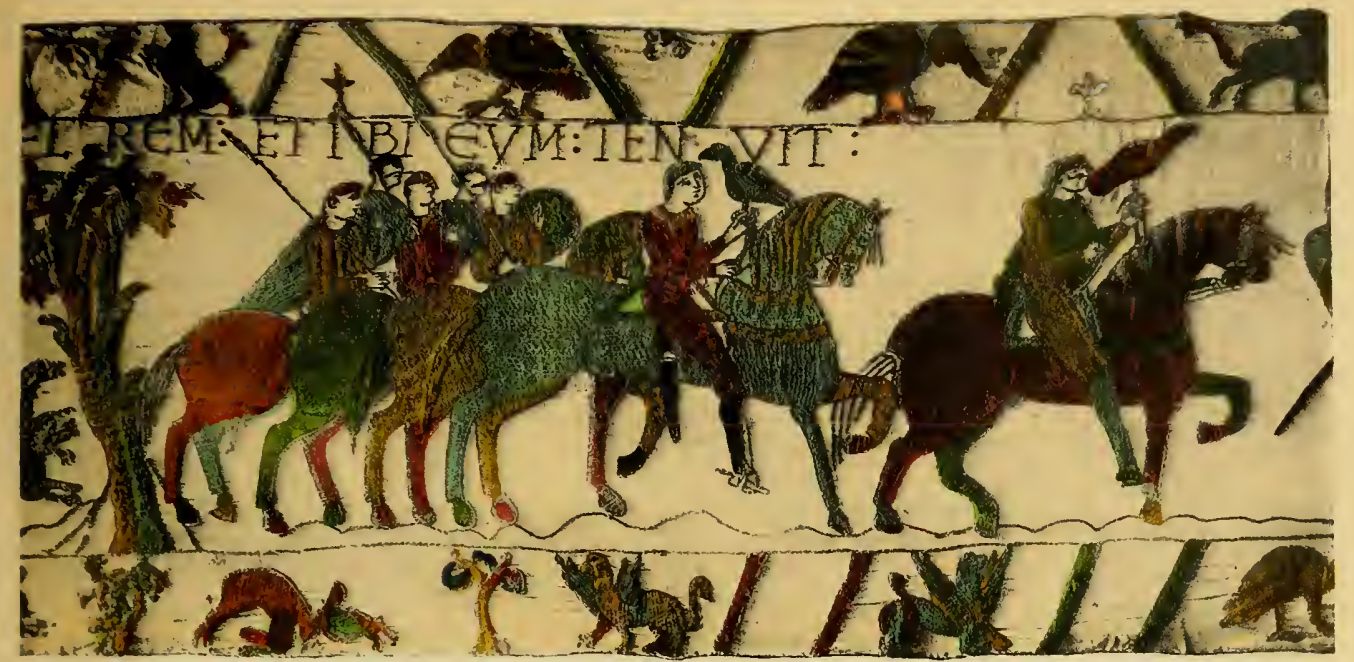

taller figure on the left, to which it is attached.

This name Turold will be familiar to the students of Normandy in another famous connection, for it was a Turold (much at this time) who put at the end of "The Song of Roland" his inscription: "This is the end of what Turoldus wrote."

After the arrival of the messengers the next three panels deal with Guy's reluctant submission to his overlord; then comes the handing over of Harold to William. The Tapestry here closely follows Wace, save in one odd particular-that it reverses the order of the scenes and does not make quite clear the insistence of William; at least, that insistence and the importance of the urgent orders which William sent are not evident to a modern man looking at the document. But there is an element which might have made it clearer to a contemporary, and this is the accoutrement of the messengers. I have spoken about this in another aspect in the Preface. They are presumably

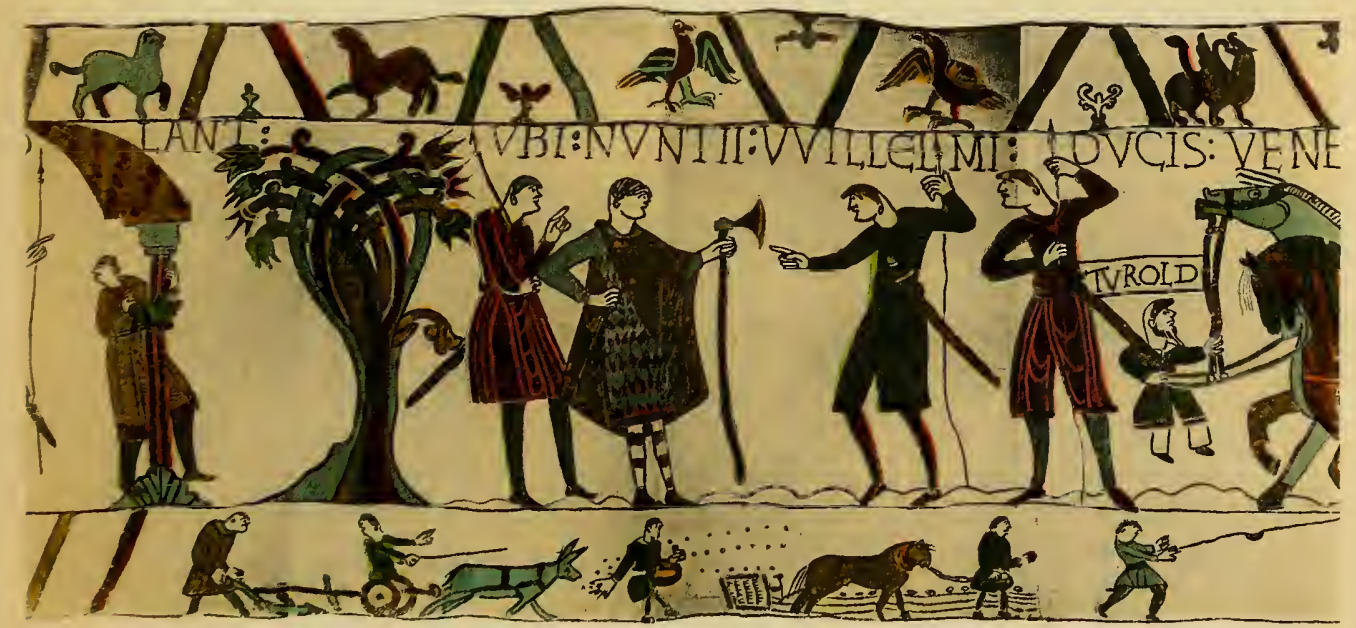



$\{1$

$-$

$-3-5$

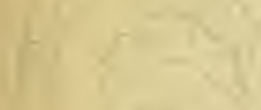
15

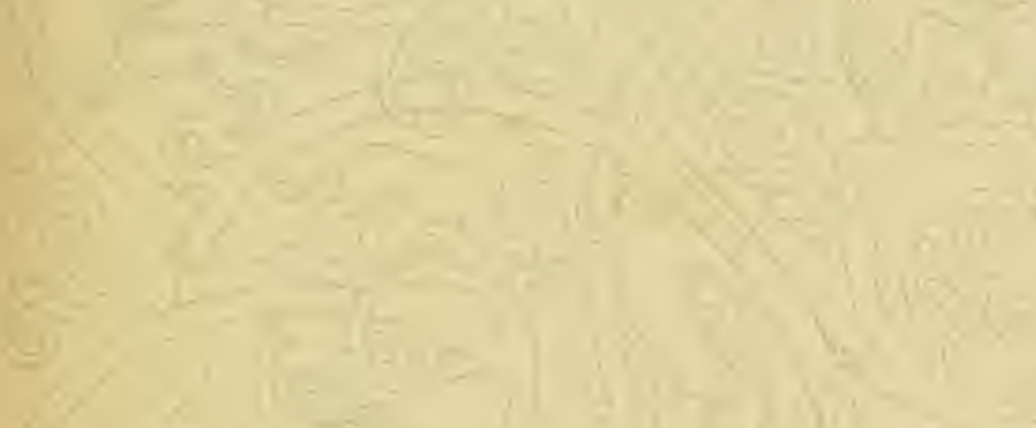

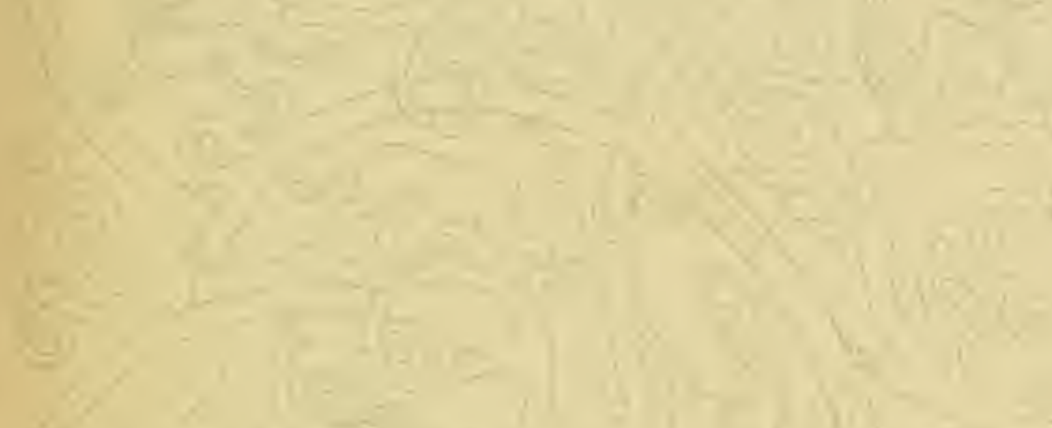

1 $x$

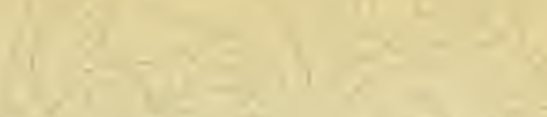

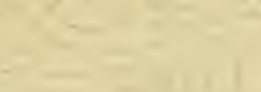

$x^{4}=5$

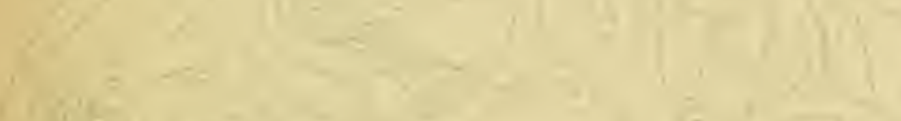

$-x+\frac{1}{2}$

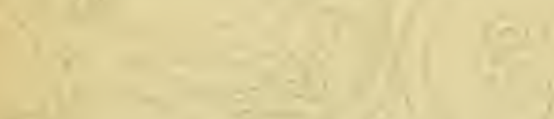

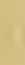

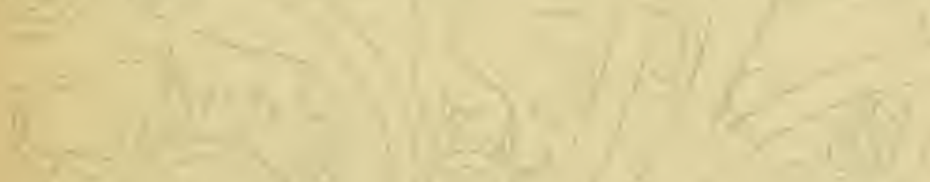

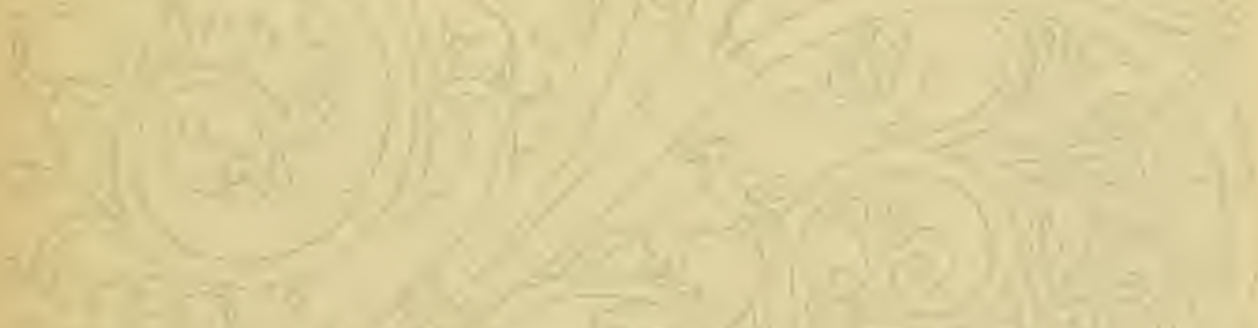

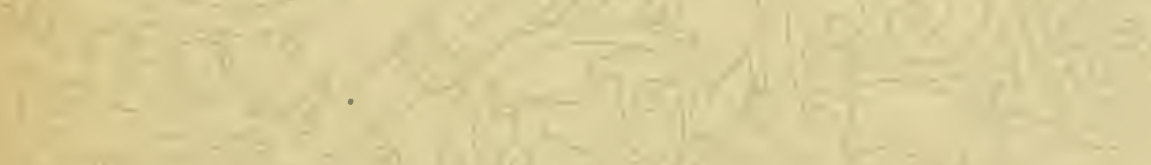

$\left(\begin{array}{ll}x-4 \\ 1\end{array}\right.$

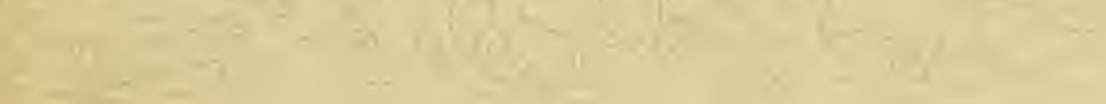




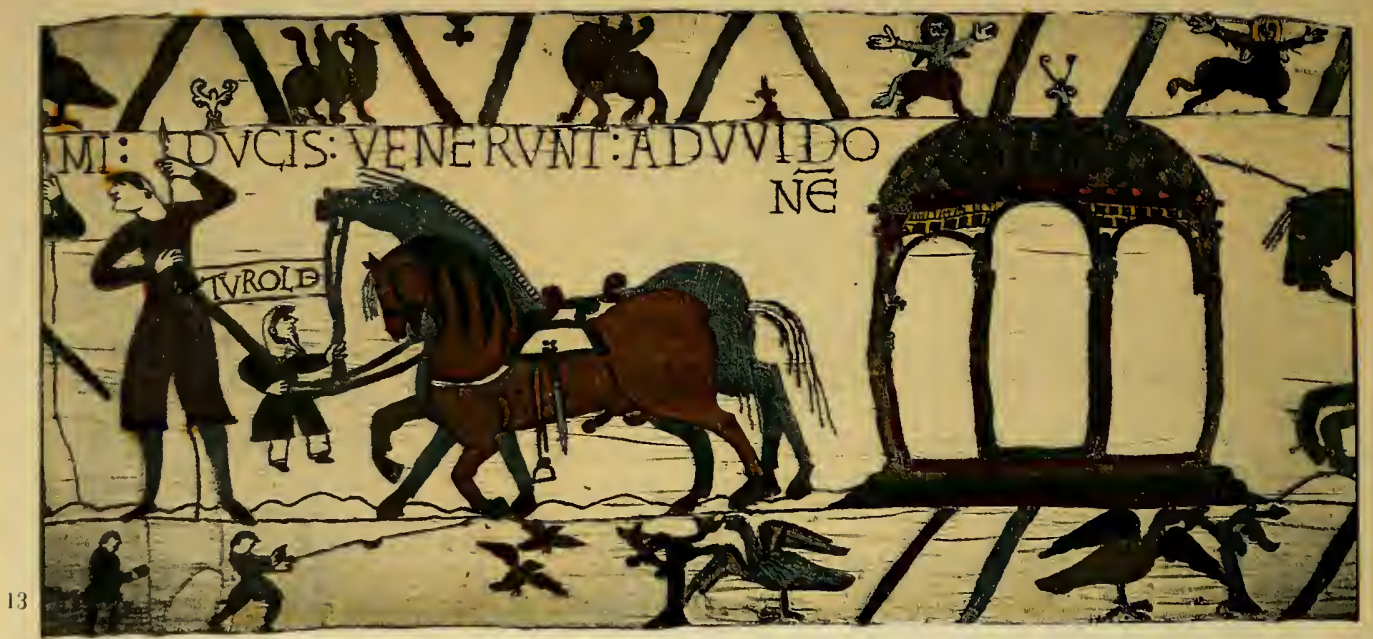

men of high position in William's court, for they bear fully developed heraldic signs upon their shield. It should be remarked, however, that save for shield and lance they are not armoured, and whether to indicate haste or the pacific character which William designed to retain as long as possible in their mission, they are not even helmeted. There is another point in these panels well worth the attention of the modern reader interested in the date of the document. We have in the border beneath an episode of a man fighting a bear, and somewhat to the right an episode which may be the introduction of tropical animals - the larger Felidæ, panthers perhaps. The first subject is certain, the second probable. Now, here (with many other examples in the long border above and below) you have the influence of the bestiaries (that is, the twelfth-century books describing beasts foreign and imaginary), and these, in turn, are the product of the Crusading march. In other words, these details fit in with all the rest of the converging evidence which forbids

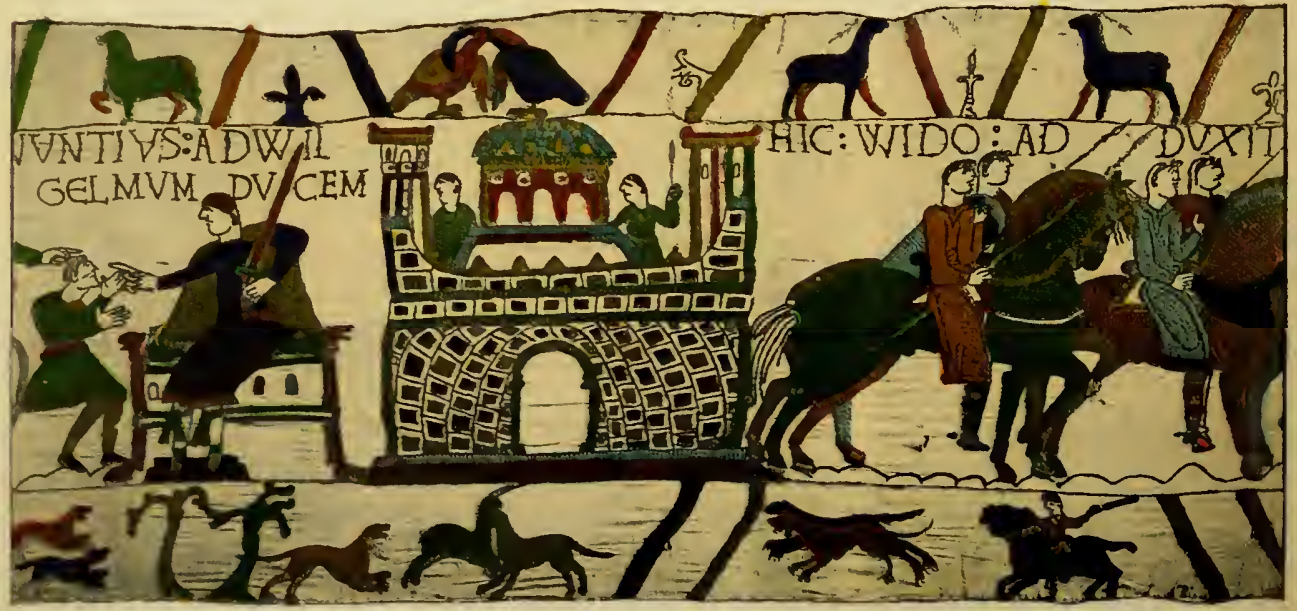




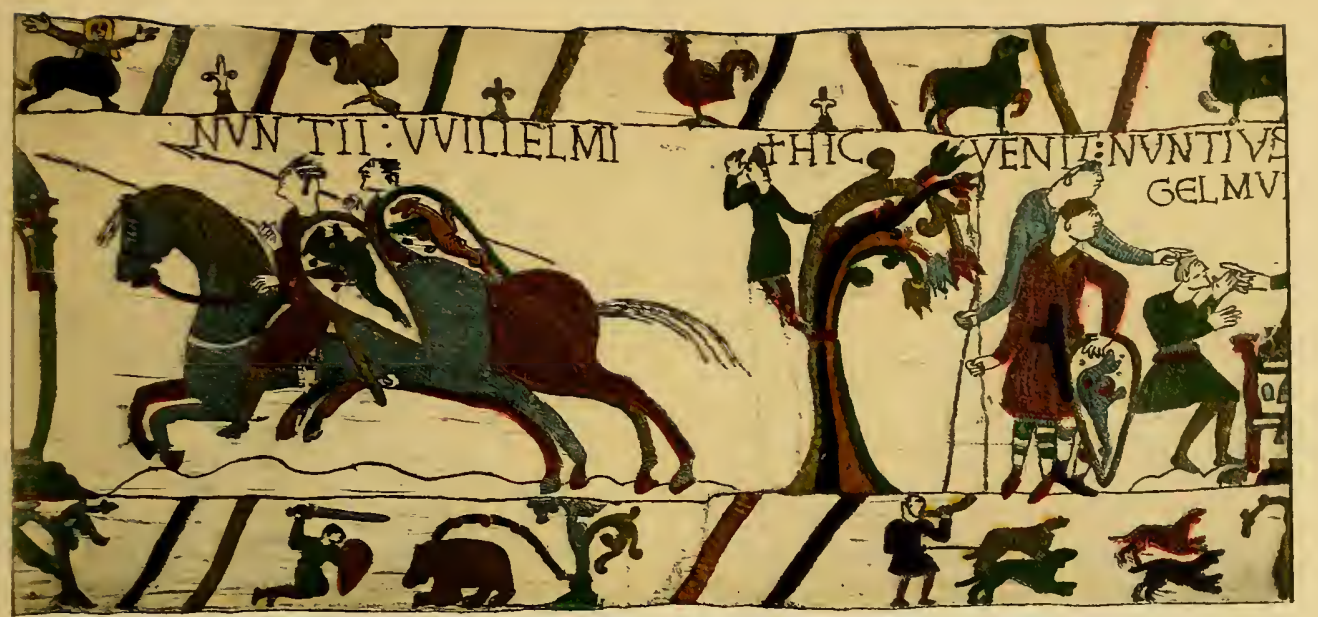

us to doubt that the document is of a later date than the Conquest itself.

The last of this group of panels, the 16 th, represents the bringing of Harold to William by Guy, and there follows a most interesting group of not less than ten panels, which form a separate episode in the story, and one which is for many reasons of high historic interest.

This episode is that of the Breton War, and it is curious to note that the rude though vigorous work of the Bayeux Tapestry tells us more about it than any other authority. The importance of this contrast between the Tapestry and the chroniclers will be at once apparent. It means that some tradition or some lost document ascribed to this somewhat inconclusive expedition into Brittany holds a great place in the story of Harold and his relations with the Conqueror. No one who looks at the Tapestry can doubt for a moment what the point of this episode is. The point is that Harold, joining with William in the expedition, proving of great service, rewarded by William,

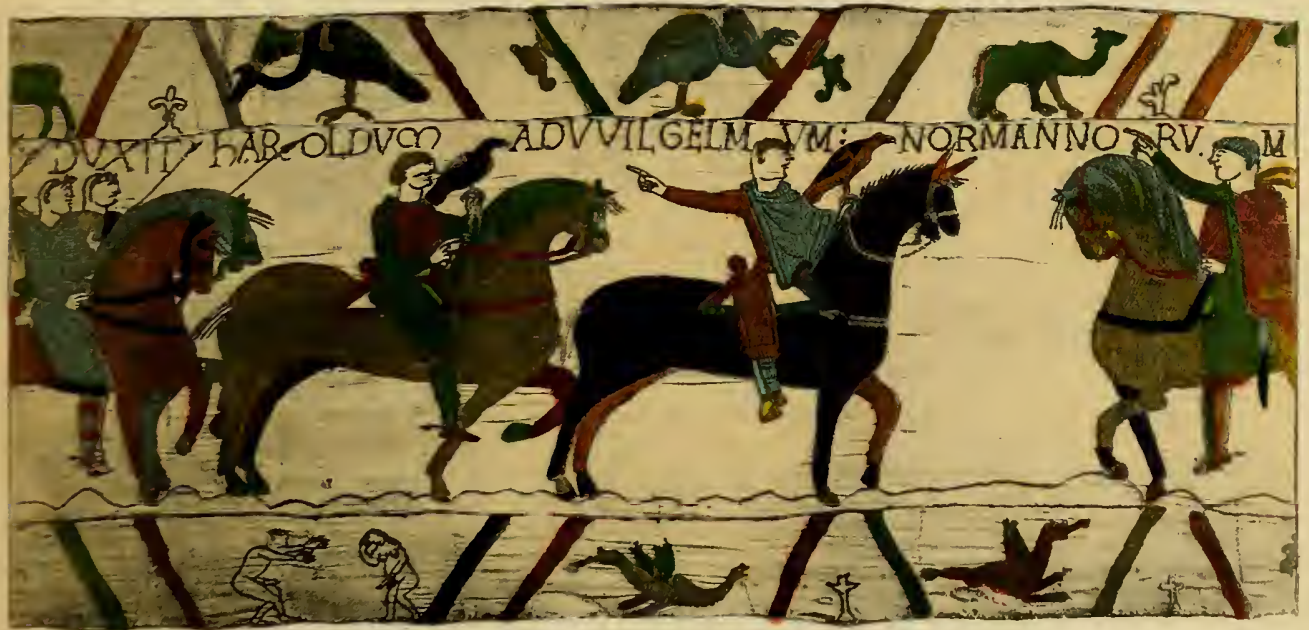




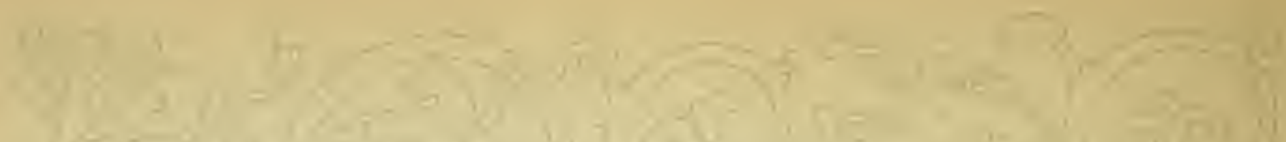

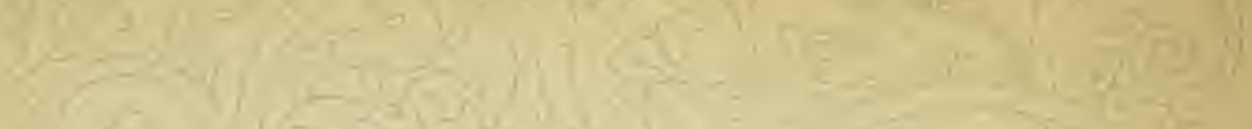

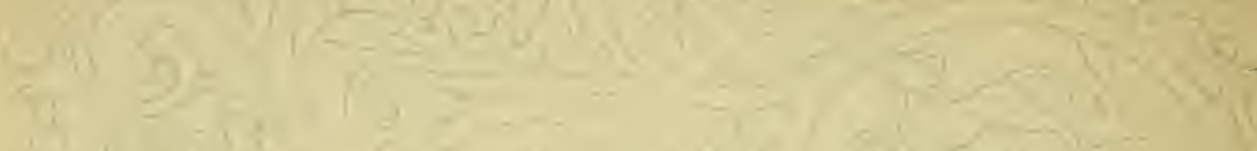

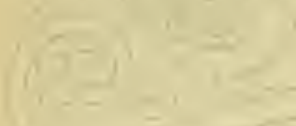

15.

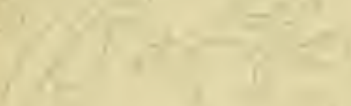

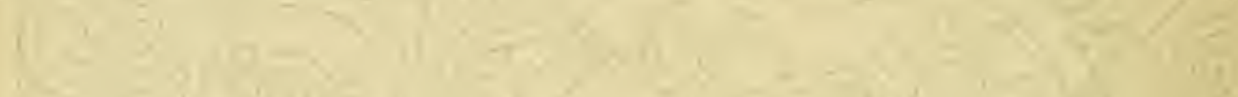

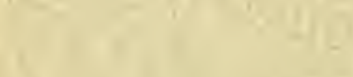
18 $(18$

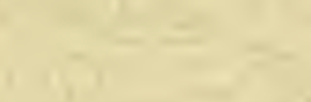
14.

-

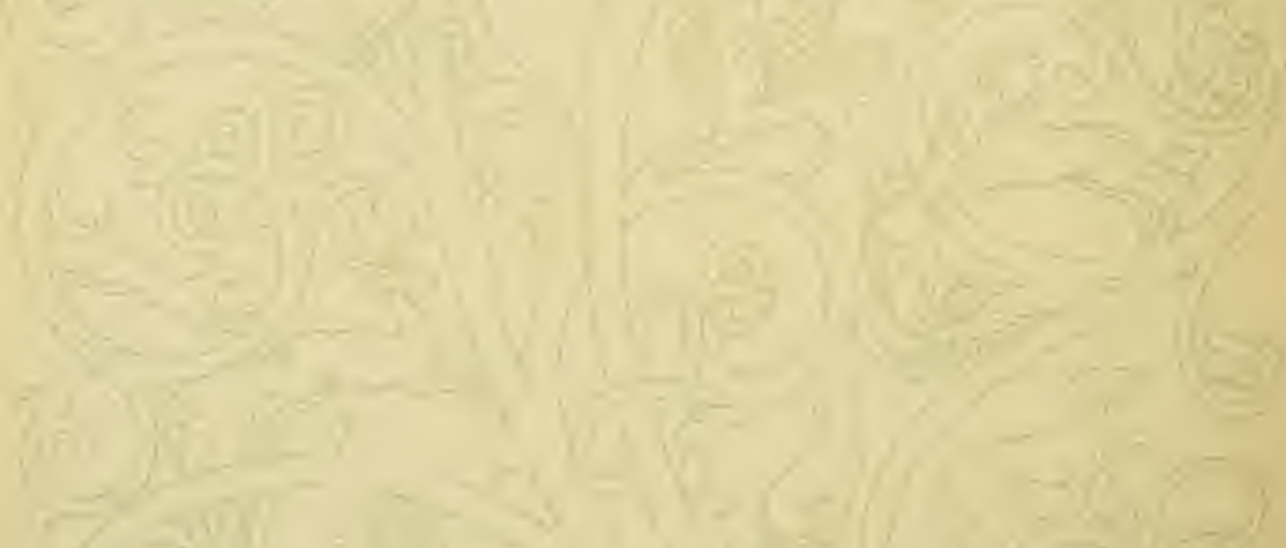

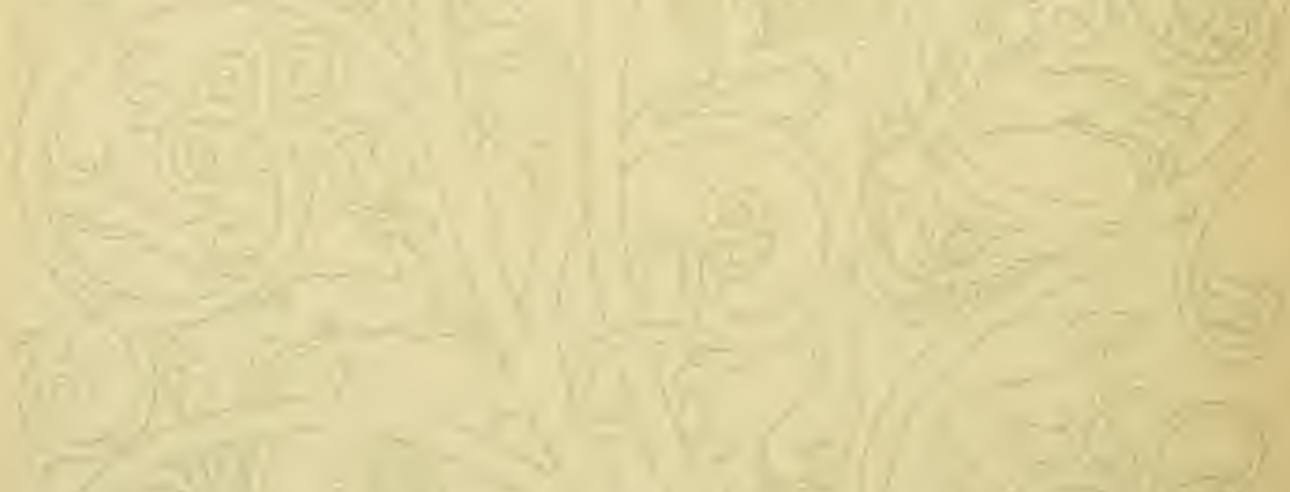

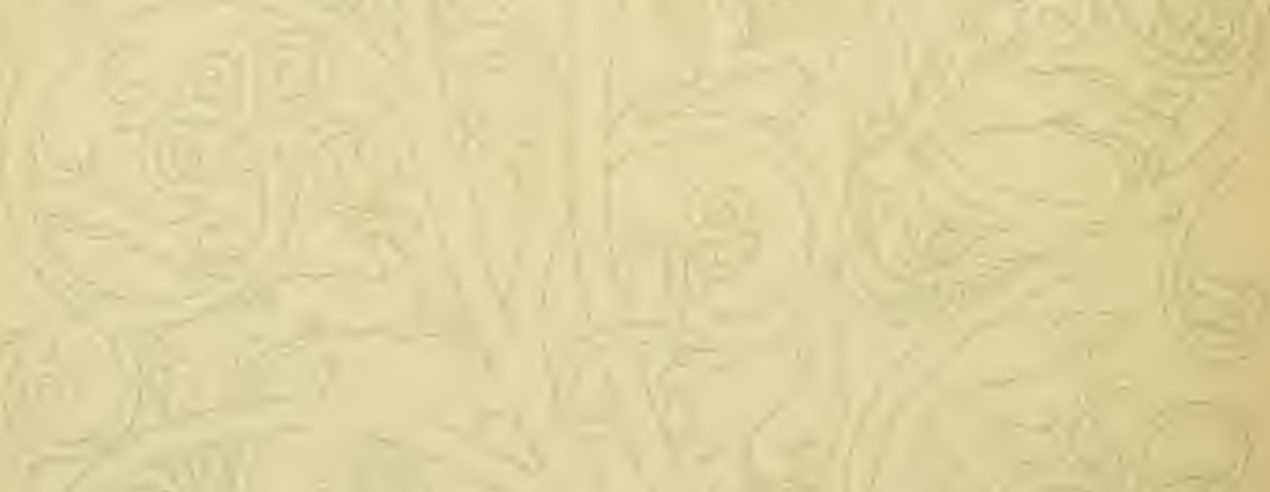

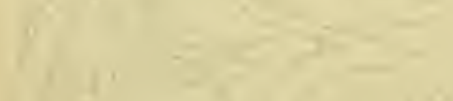

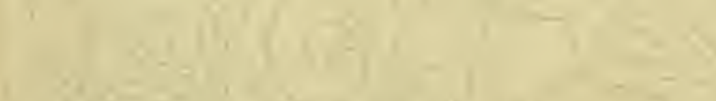

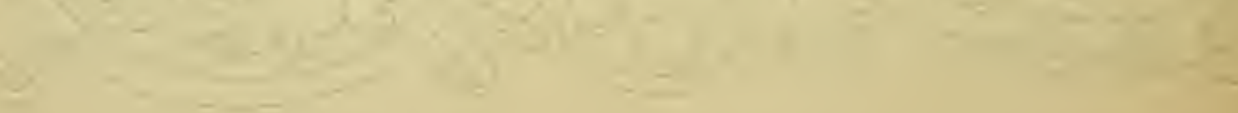




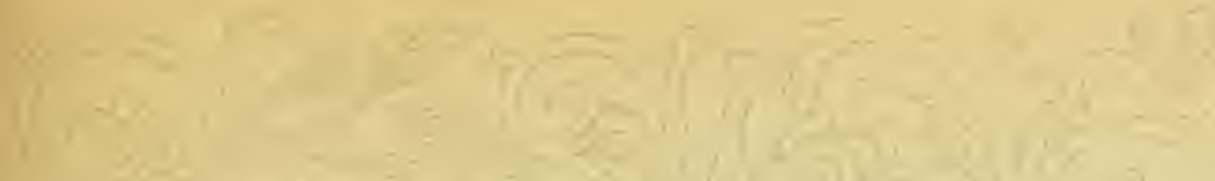

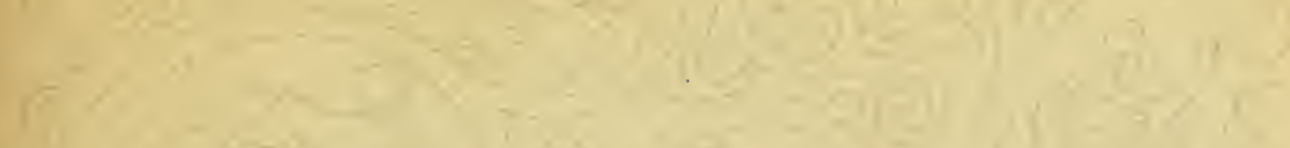

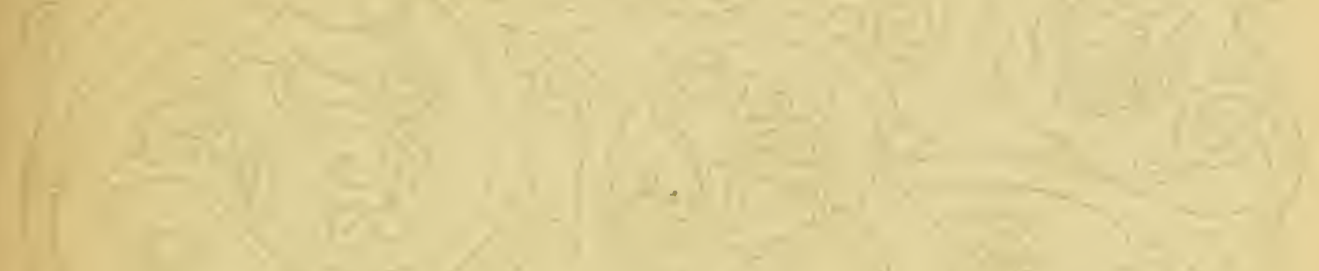

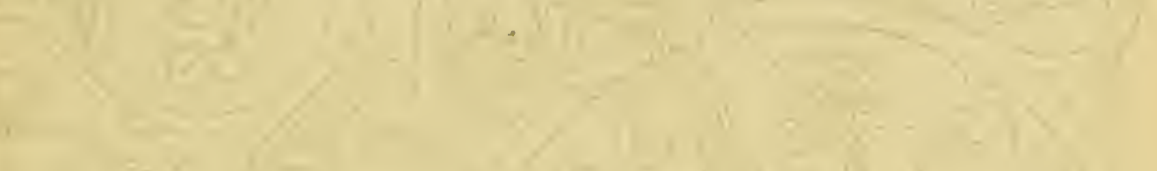

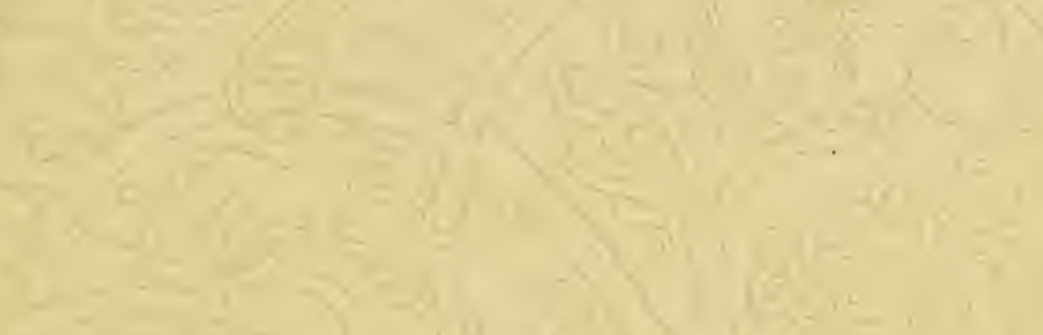

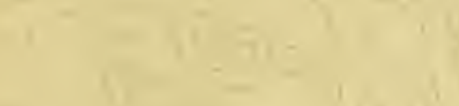
-

-

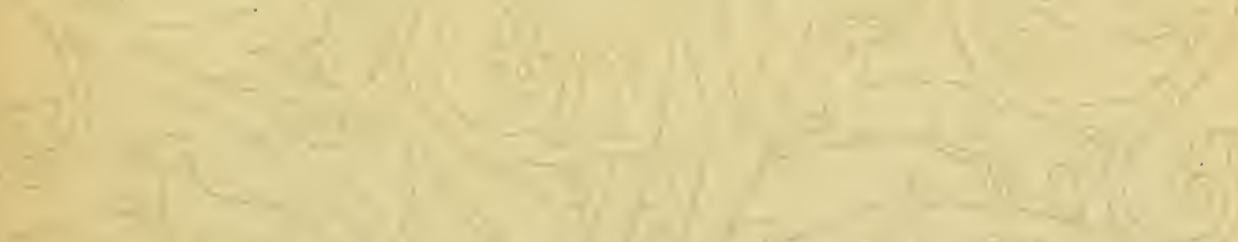

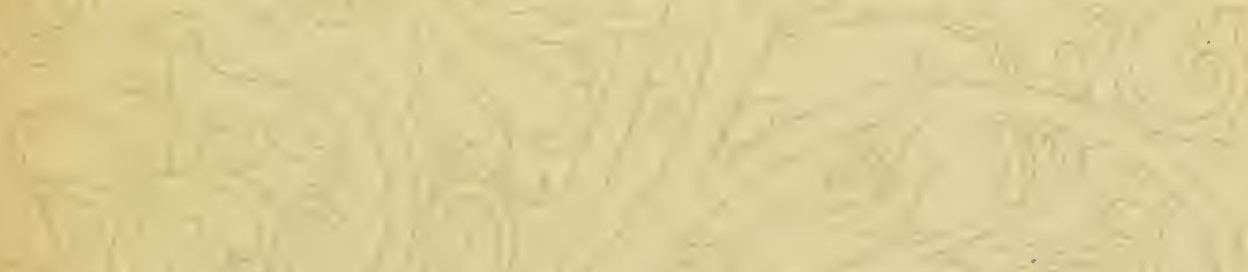

F.

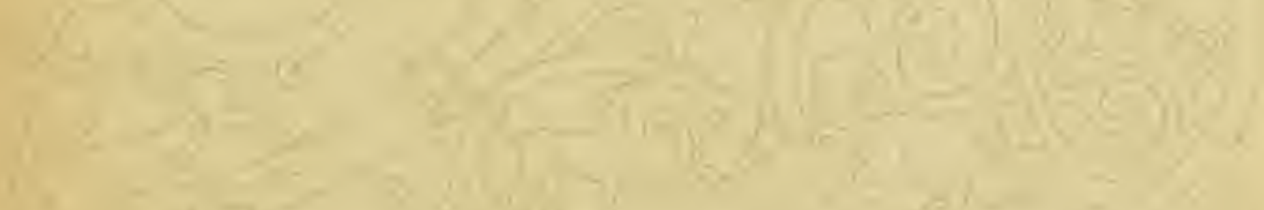

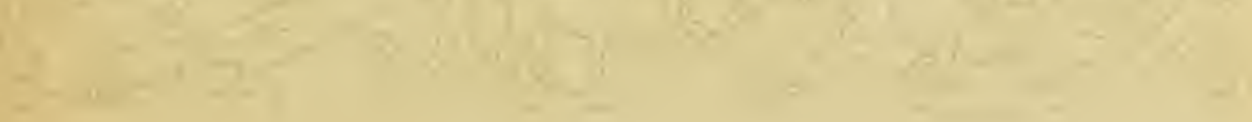




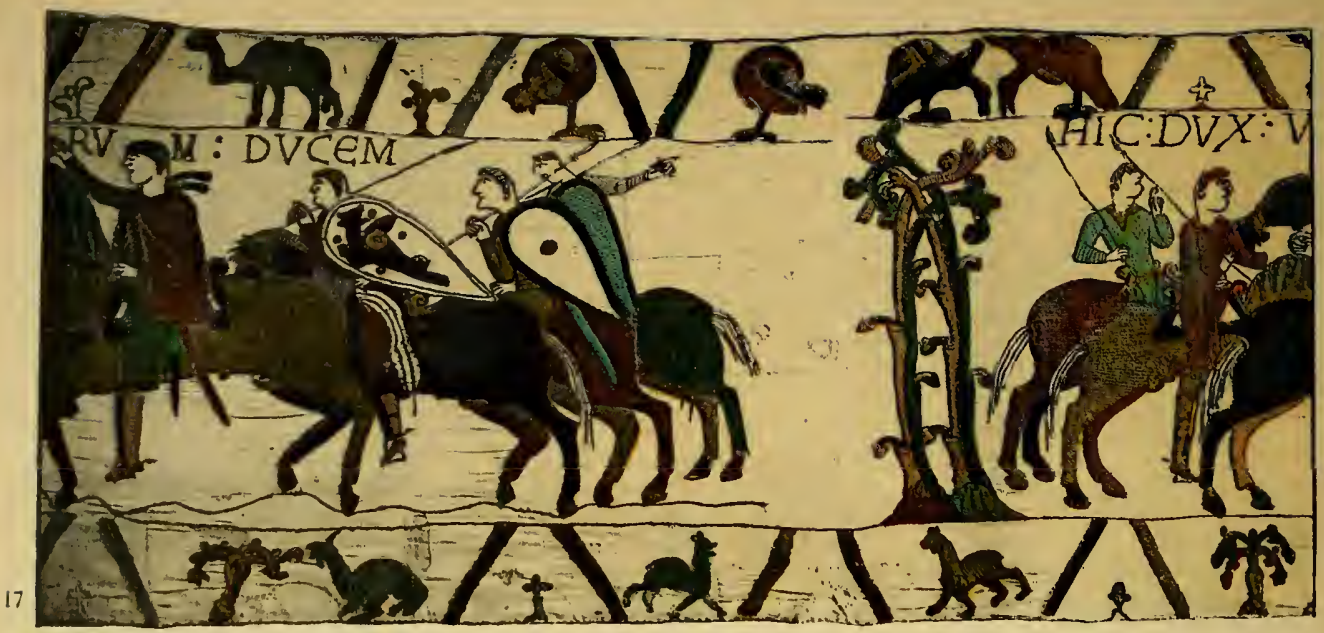

and in general much more closely bound to the Norman court through this accident than he otherwise might have been, was in all that followed a treacherous friend. The implication is clear. Whoever designed the Tapestry, or furnished the materials from tradition, believed and wanted others to believe that Harold was not only formally a traitor according to the mere rules of feudal society, but also morally and fundamentally one, as having forgotten and abused a close personal tie, the product of armed service. It is evident that in the imagination of contemporaries, and therefore in the tradition which they built up, this march of Harold side by side with William into Brittany colours the whole story.

Wace has but a few vague lines just telling us that there was such a thing as a fight with Brittany at this moment. If I am not mistaken, William of Poitiers is the only chronicler who gives us anything like an account, and even so his account is absurdly short and undetailed, though it tallies, both as to the places mentioned and as to the episodes with the

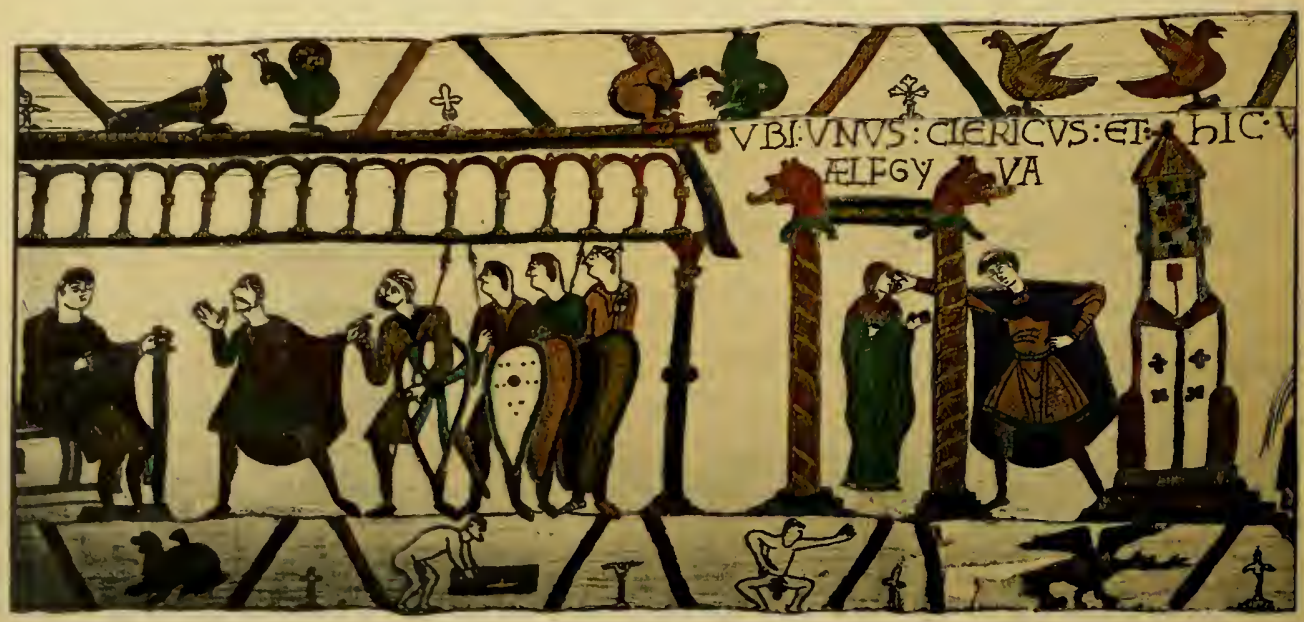




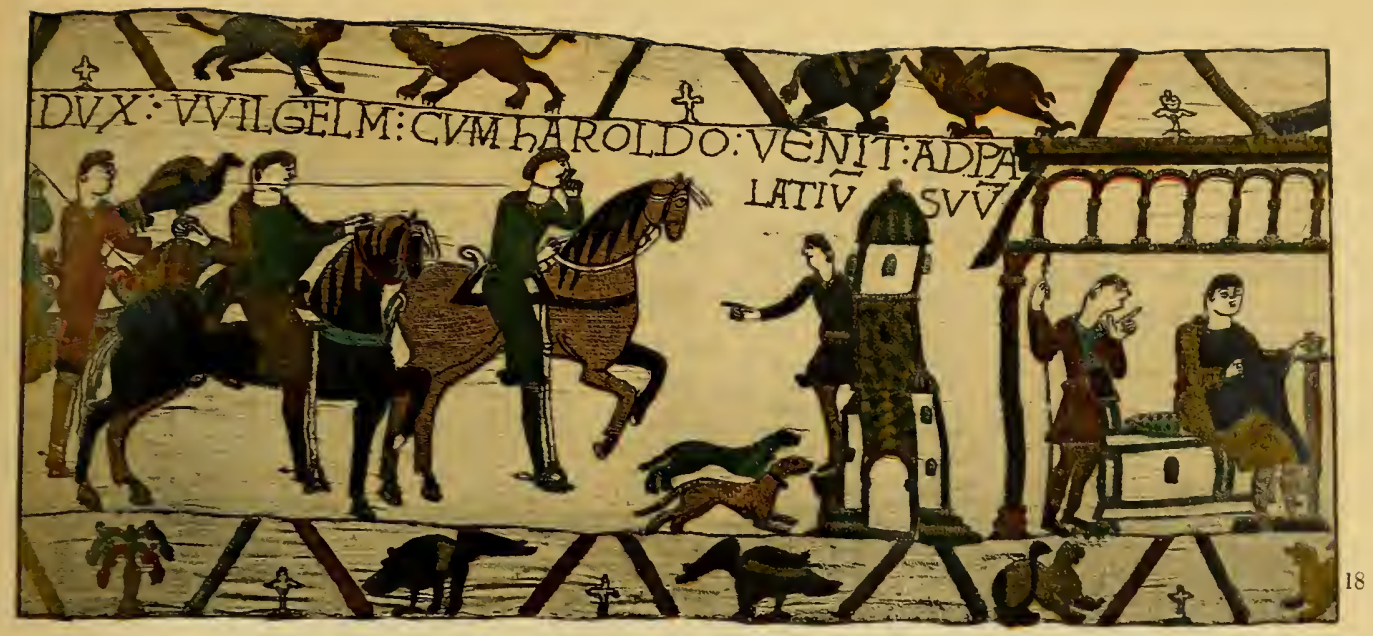

Tapestry. The Breton Chronicle, I believe, says nothing about it.

Turning to the details of these ten panels ( 17 to 26 inclusive), one notes again the fully developed armorial bearings upon the retinue of William, and in the next panel the convention of the Palatium, ${ }^{1}$ that capital institution of Europe, the seat of government in every land; in one aspect a building, in another a body of men, and throughout the West for a thousand years the continuator of Rome.

It is also interesting to note the attempt at portraiture in the case of William. The round bullet head and square shoulders of the Gaul (the slight and distant strain of Scandinavian blood seems to have influenced neither his soul nor his body) are emphasized in this first introduction of him, and it is possible so to emphasize the portrait because he is so represented in this early part of the series neither helmeted nor crowned.

The episode of the priest and of the woman who is given the name of "Aelfgyva" has, if I am not mistaken, remained quite inexplicable. I will

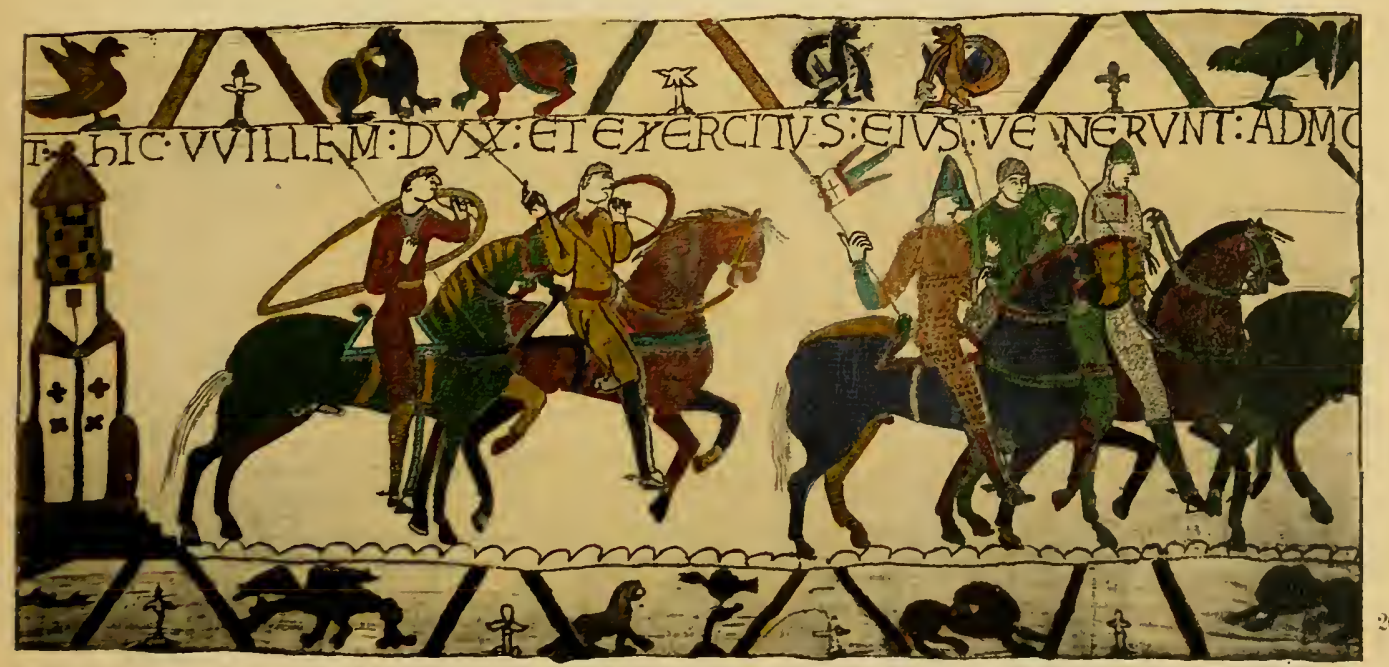





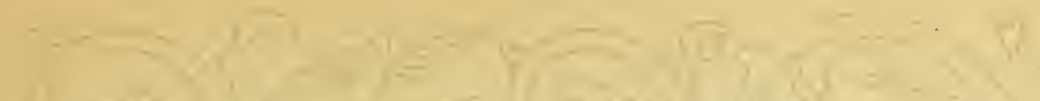

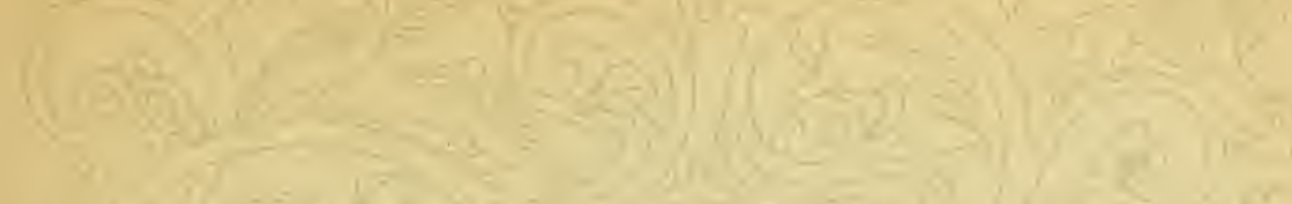

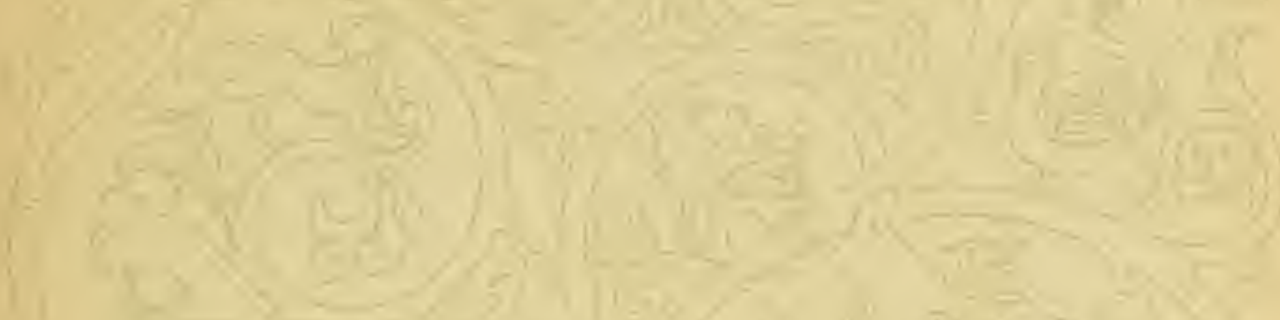

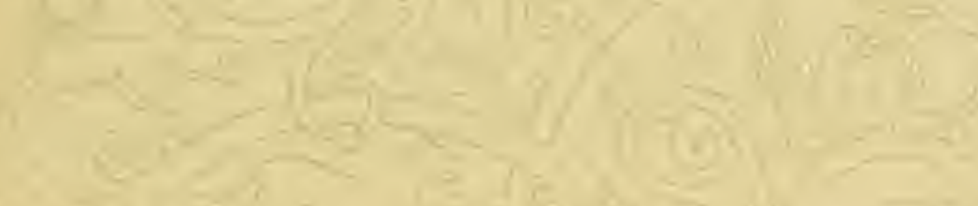

$(a$ a)

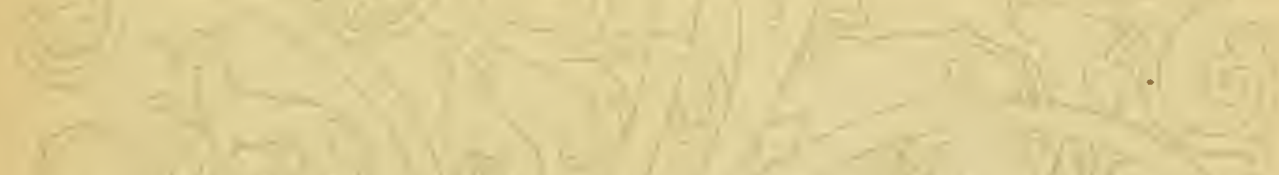

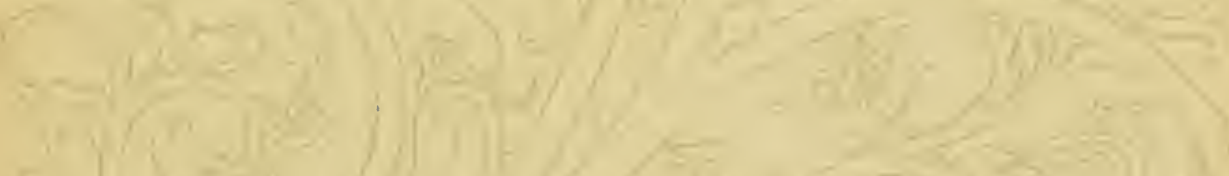
|

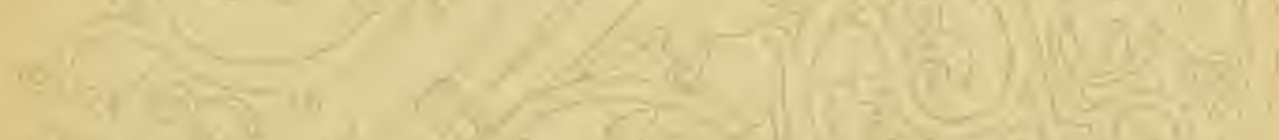

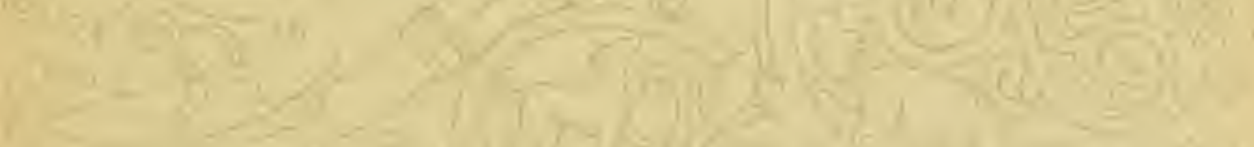
$1+1 \leq 0$ 


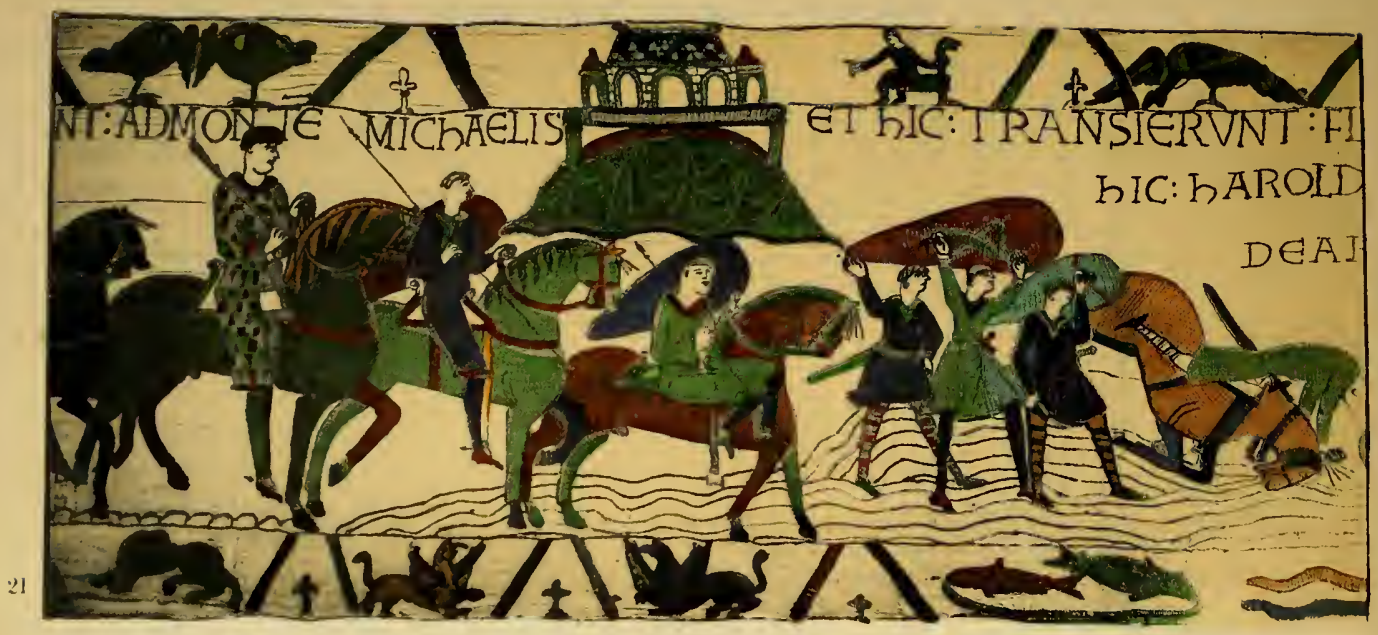

not follow my predecessors in the criticism of this, for I can suggest nothing new with regard to it. All who have written on the Tapestry with any care for historical accuracy and for the spirit of research have admitted their incompetence to explain the thing. There follows upon it the riding out of the army across the neck of the Cotentin towards the Mont St. Michael, which was, as it were, the boundary stone between Brittany and Normandy; and here we have the first appearance of those knights in full armour, which are so characteristic of the chief episodes in the Tapestry and whose costume is of such value to us in estimating its date. There was some incident at the crossing of the Couesnon (the boundary river between Normandy and Brittany) which evidently vividly inpressed contemporaries and which further emphasized the now intimate and personal bond between Harold and the Norman court.

The river was forded. Men and horses got caught in the quicksands, and

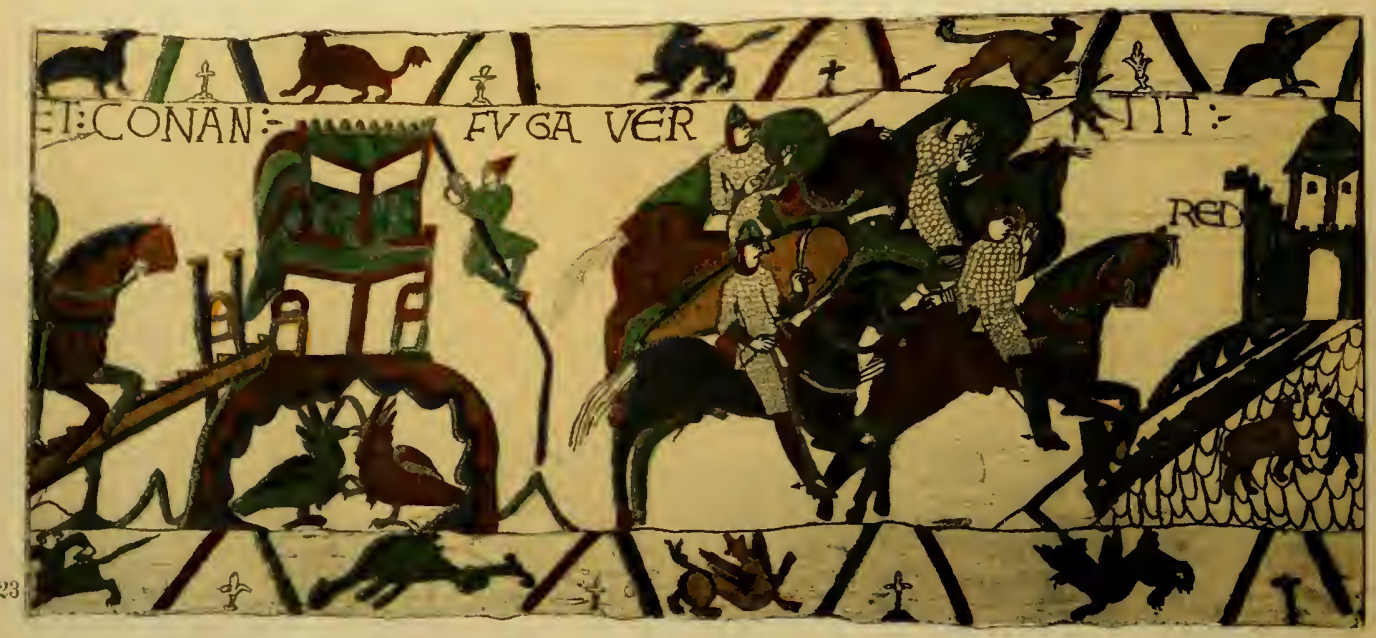




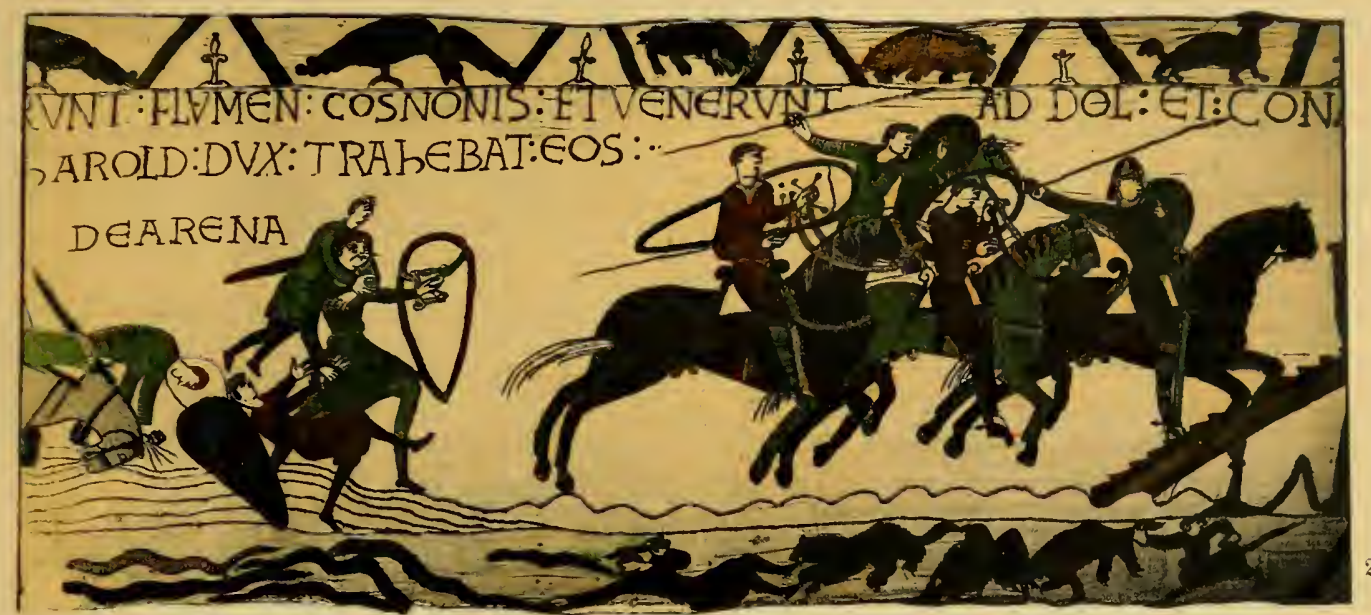

in some fashion it was Harold and his men who saved those who were in peril. It is worth pointing out in this connection that there was a bridge at Pontorson, within a few miles of the mouth; why that bridge was not used suggests an interesting conjecture. Perhaps the enemy held it, and William took his force round by the seashore to the north in order to outflank the position.

Conan of Brittany fell back on Dol, and then back again from Dol to Rennes. In the representation of the retreat from Dol you have a man sliding down a rope from the walls, which may be the memory of some incident, or more probably a conventional mark of haste. I presume a retreat upon Rennes, though the only proof of it is the single word "Rednes" and the conventional drawing to represent the town. At any rate, the "hub of the campaign " was at Dinant ; the main fight was round the walls of that town, and Conan is represented in the Tapestry as surrendering it. $\mathrm{He}$ "offers the keys to William" in the inscription upon this panel.

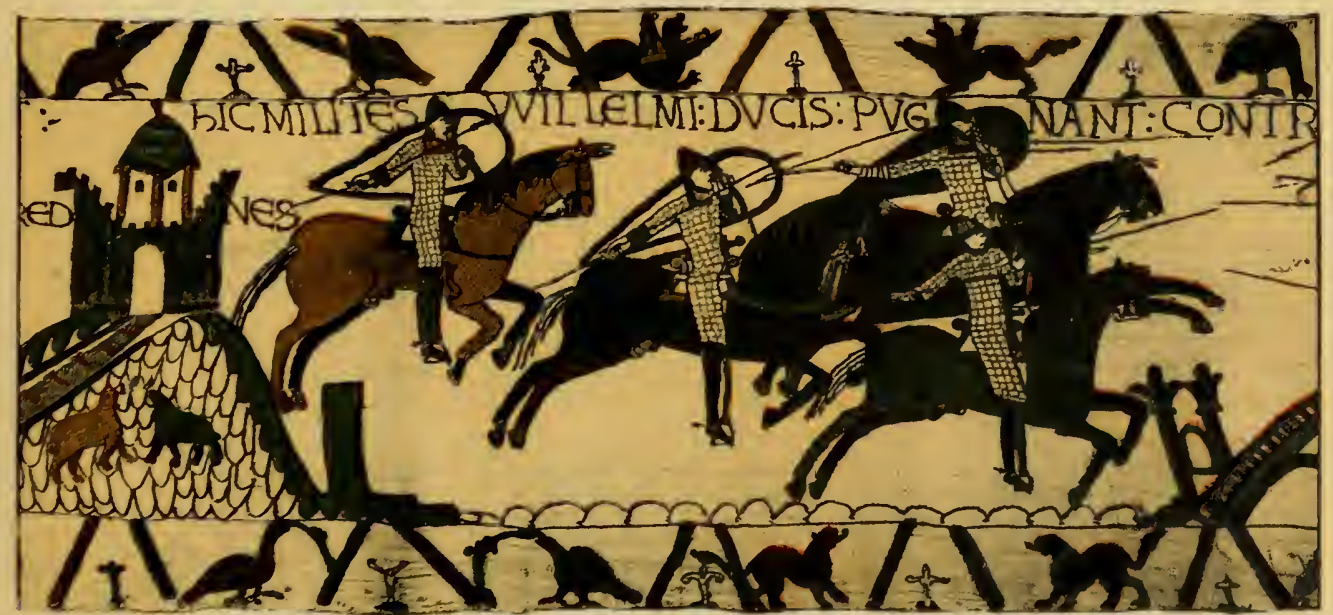





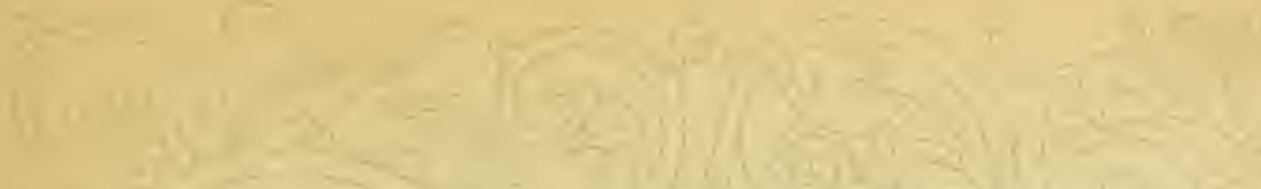

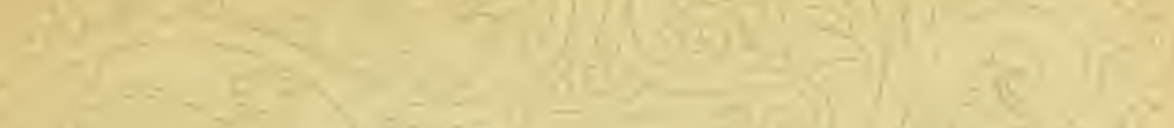

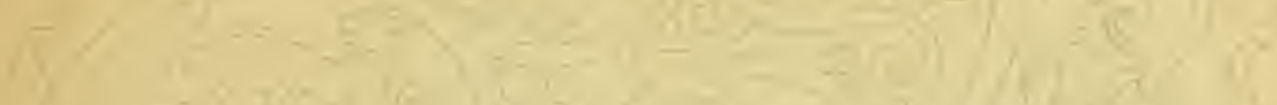

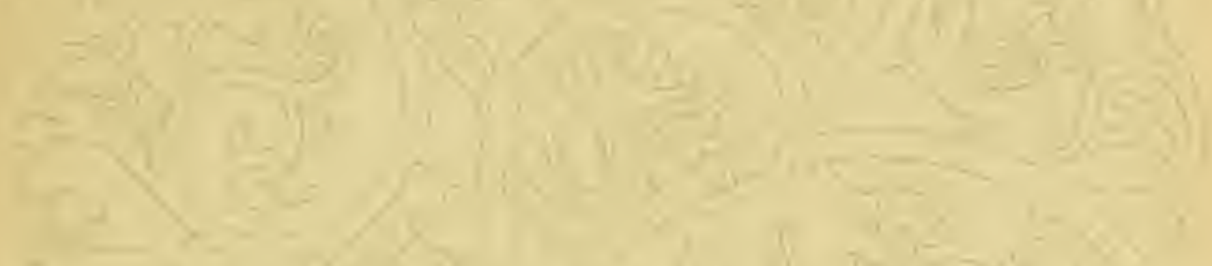

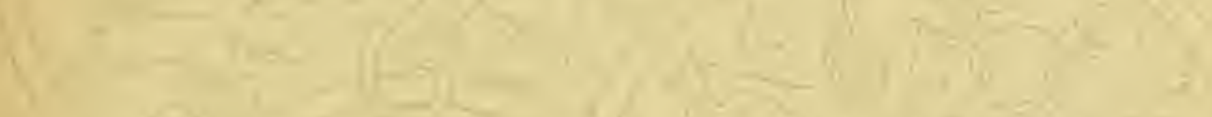
W.

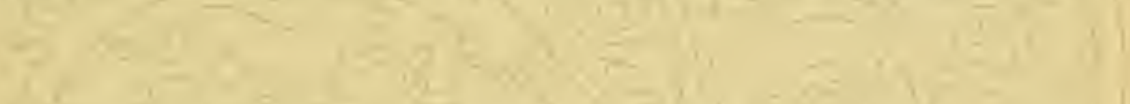

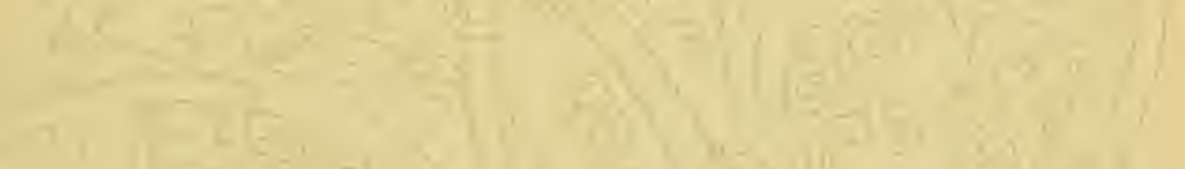

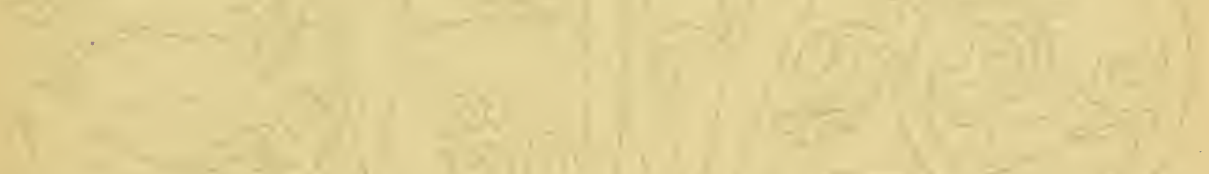

15 $=$

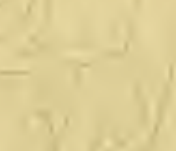

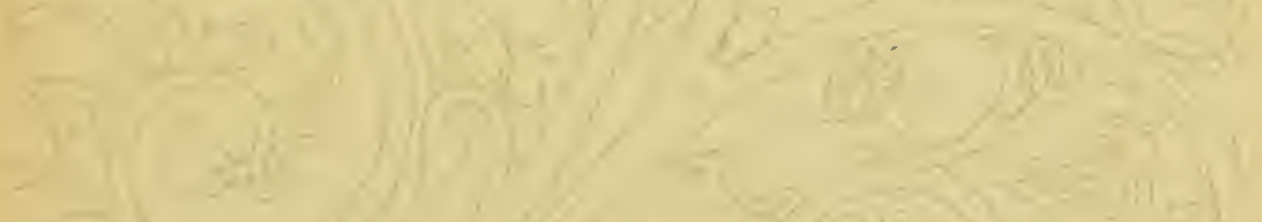

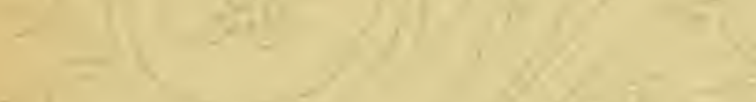

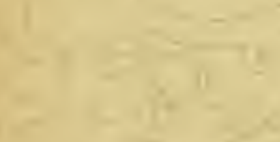

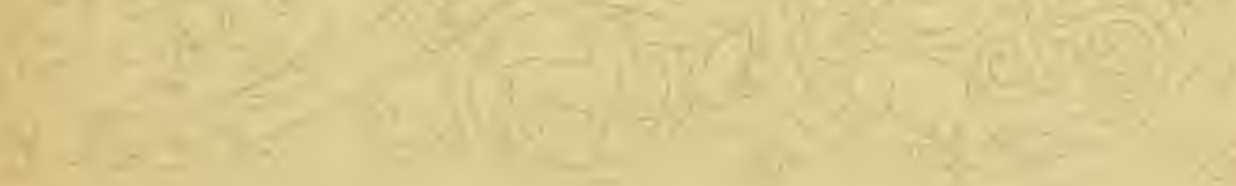




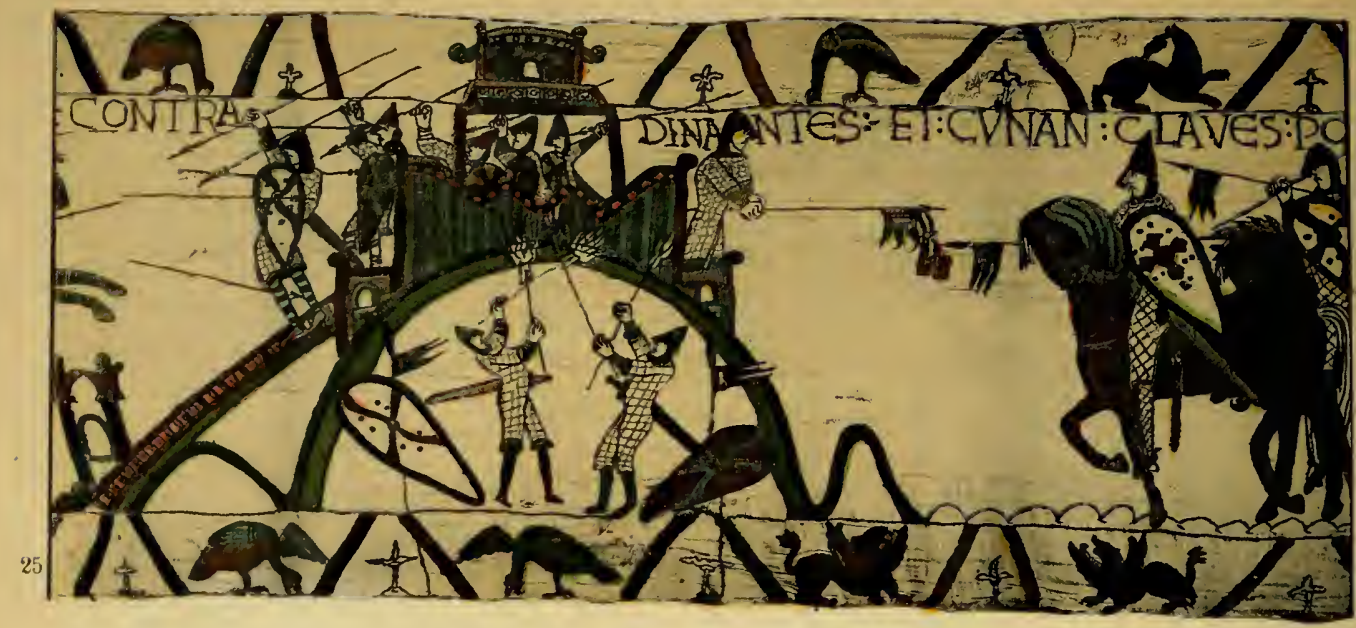

Now the very little documentary evidence we have goes to show that this is legend rather than history, and further suggests the comparative lateness of the Tapestry, for William of Poitiers tells us that the expedition was on the whole unsuccessful.

These ten panels of the Breton Expedition (which I desire once more to point out as capital in the whole story-as told in the Bayeux Tapestry) end with a short and simple but critical incident, and that is the giving of arms to Harold by William. The thing was already a ritual and the mention of nothing could have more struck the men of the twelfth century with the closeness of the personal tie between William and Harold, which all this part of the Tapestry is designed to bring into relief. It is symbolised in the 26 th panel.

The next two panels (27 and 28) represent what is in popular history the pivot of the whole story, Harold's oath. It is, of course, the chief single

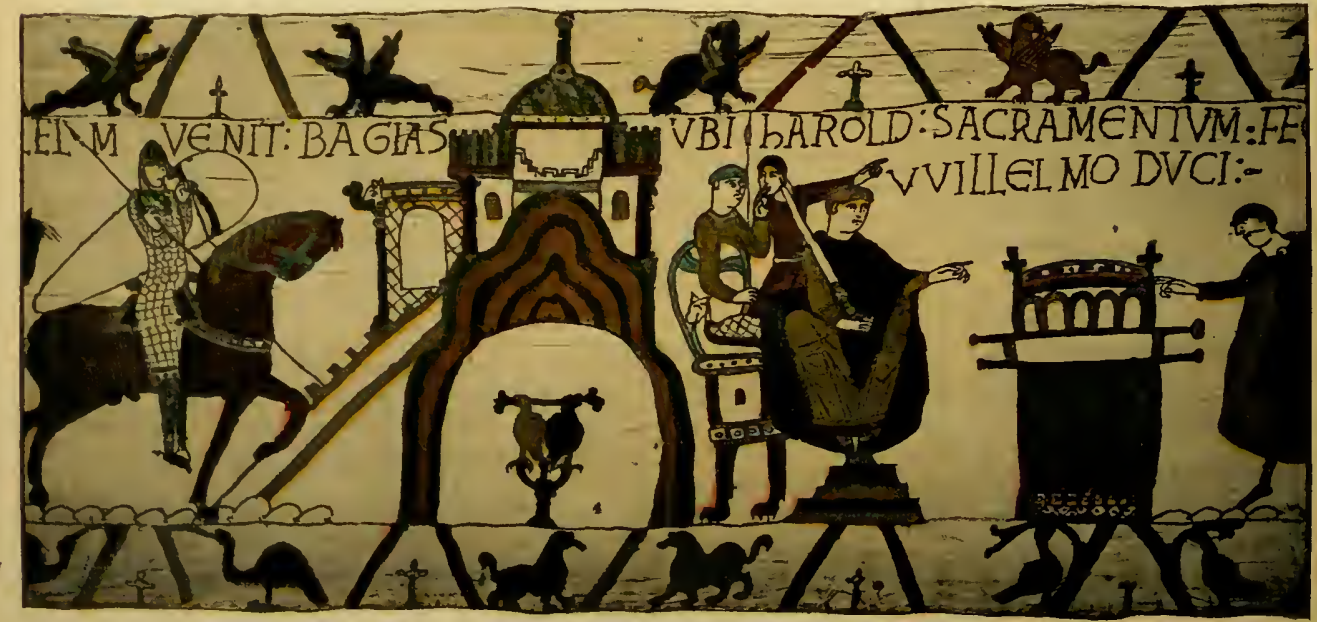




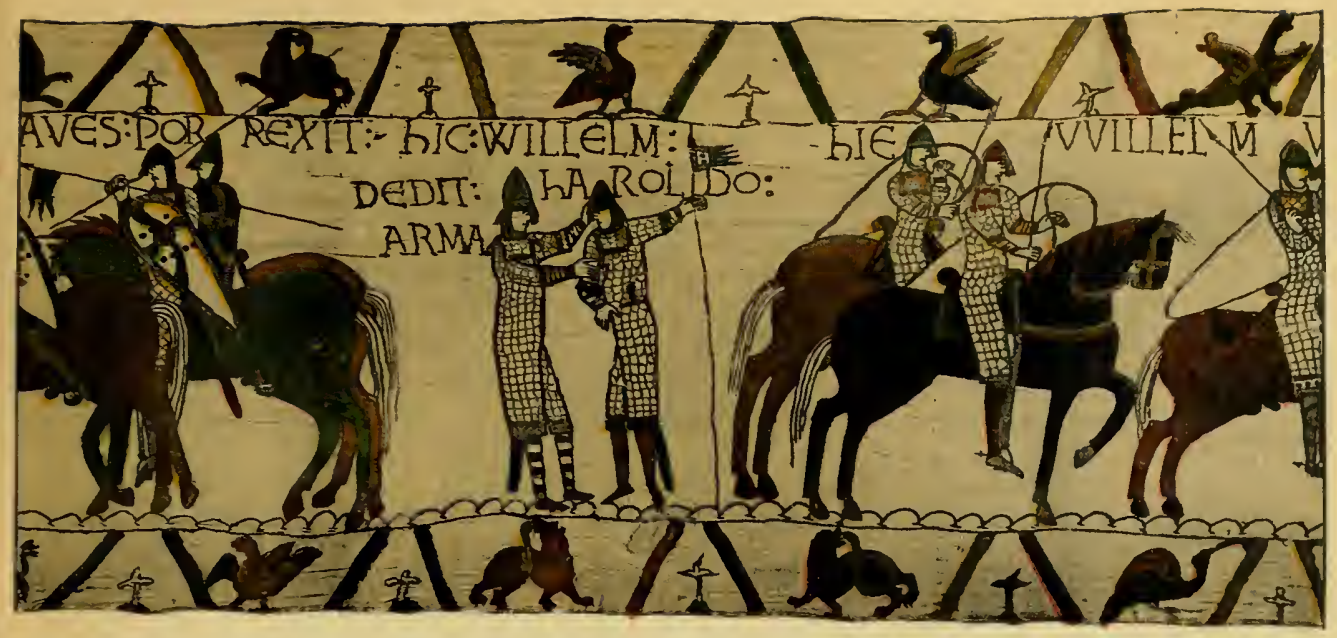

event in the story of what the Norman writers regard as his treason. Note first that the scene is Bayeux. That is important, both because it explains why this favourite town of William's should also be the custodian of the document before us, and because it again refers us to Wace and the Roman de Rou. Wace is the only author, I believe, who puts down Bayeux as the scene of Harold's oath. I will give the words from the Roman de Rou that the reader may judge :

"That he (Harold) would give up to him (William) England when the King Edward should die, and that he (Harold) should take to wife, if he willed, a daughter that he (William) had. This, if he would, he should swear. William . . summoned a Parliament ${ }^{2}$ at Bayeux as people say," \&c. \&c.

William is clothed in all the ritual garments of his authority, garments which were for the rulers of that day almost hierarchic and priestly; he is seated upon a throne, and everything is done by the artist to bring out the

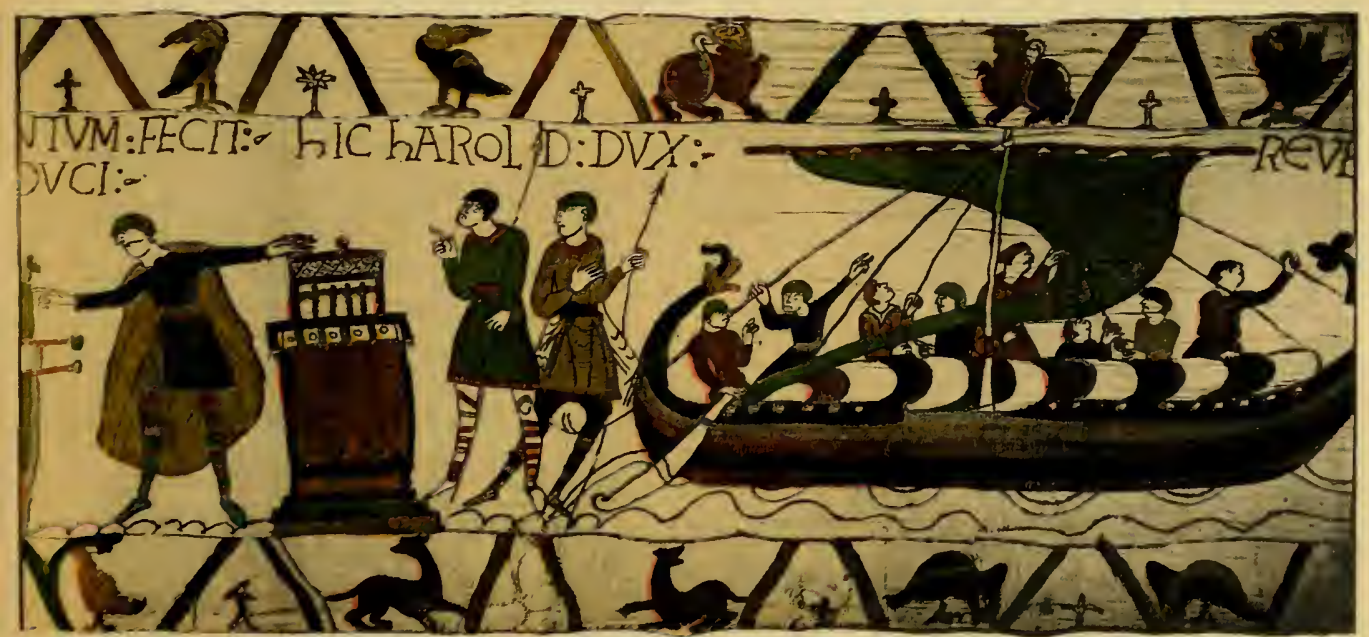




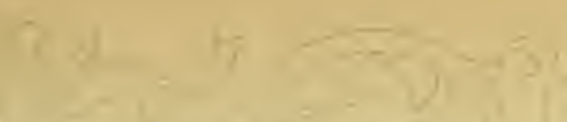

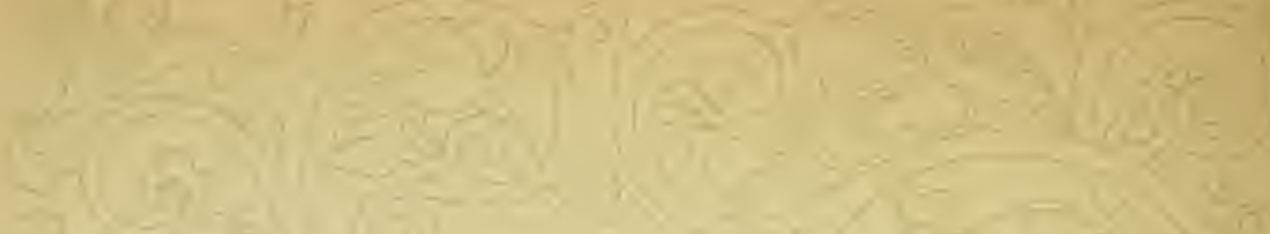

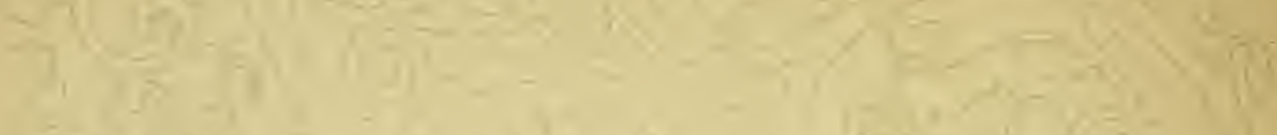
$2=11-2=1$

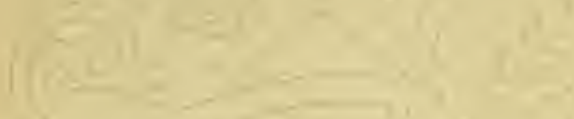

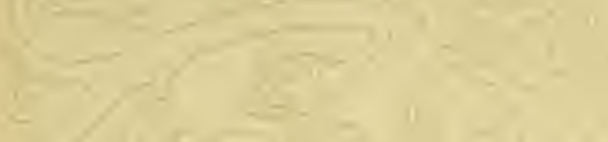

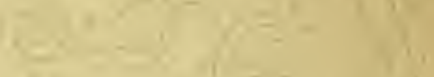

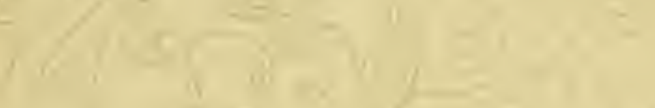

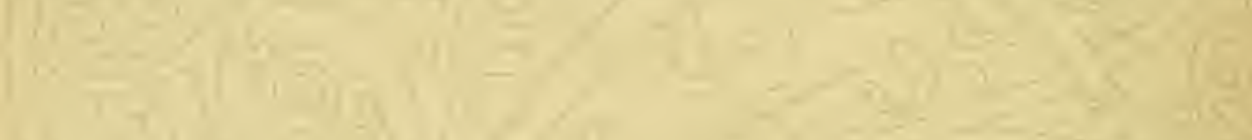
13

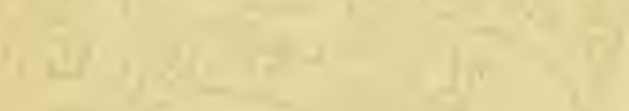

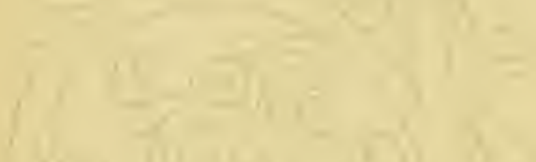
$y_{-1}=1, y=5$ $x=3$

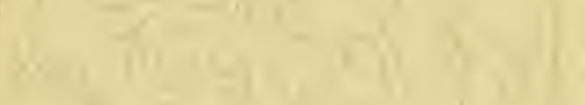

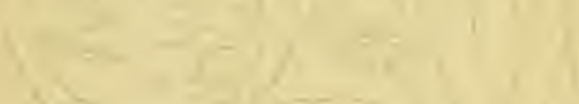
$x^{2}-2=2-3$

4. xing $-2=0$

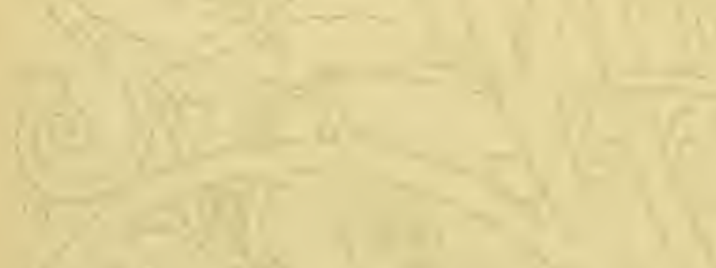

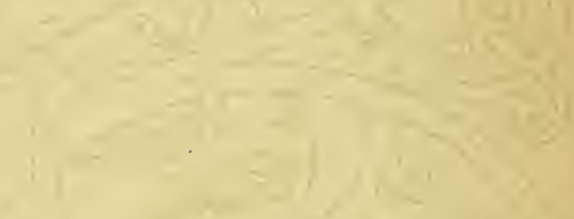

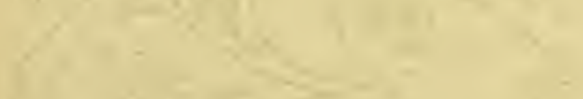

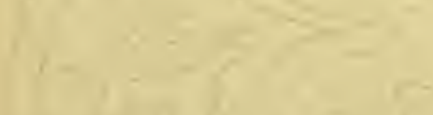

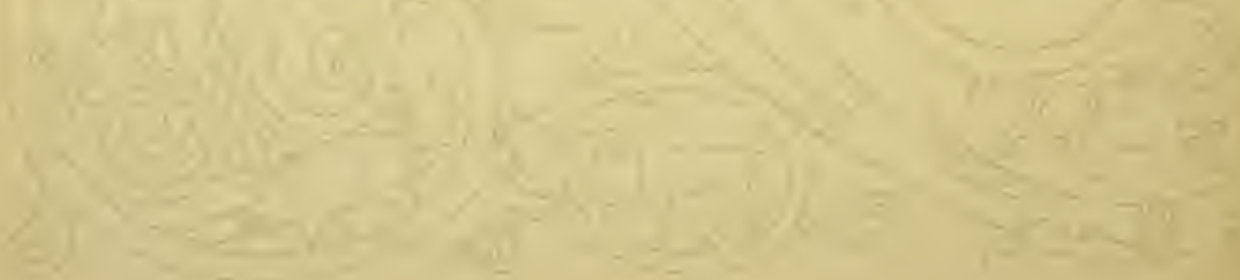

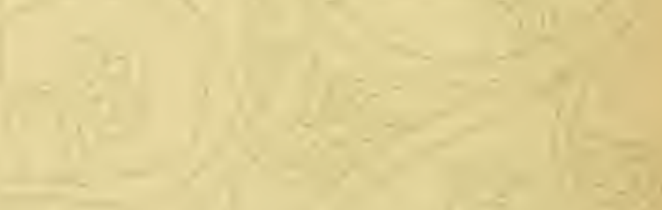




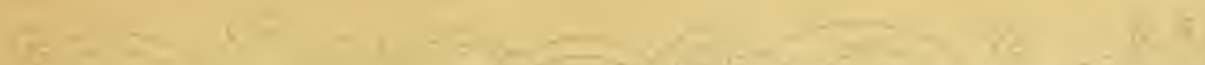

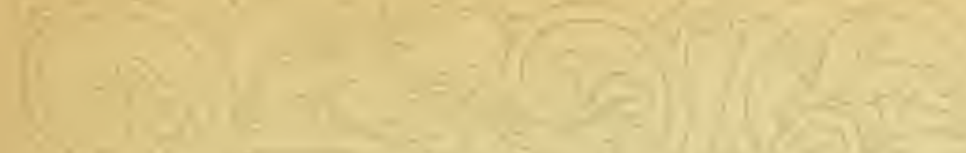

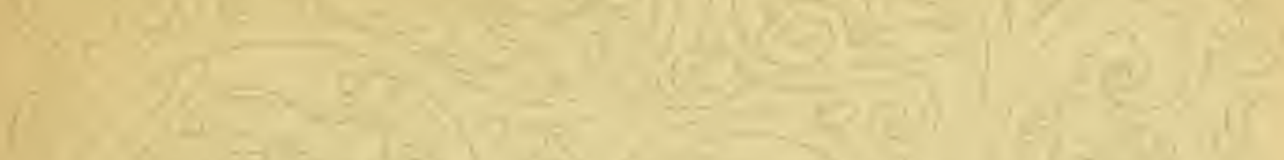

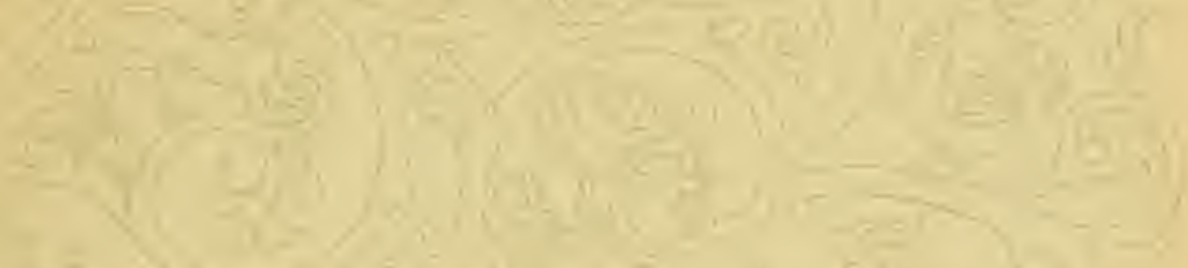

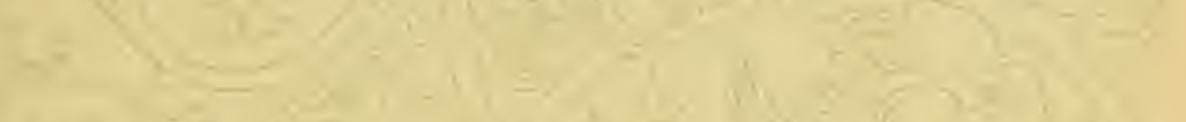

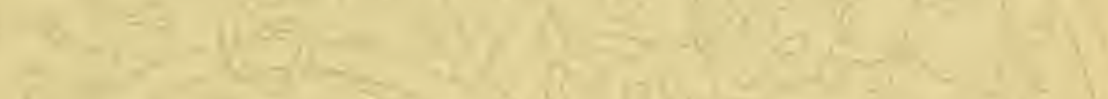

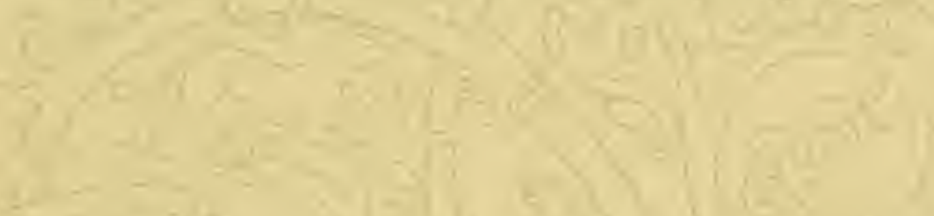

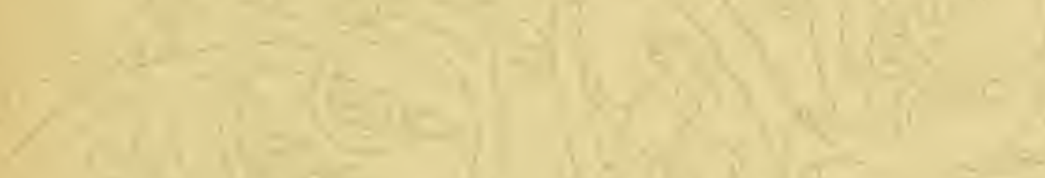

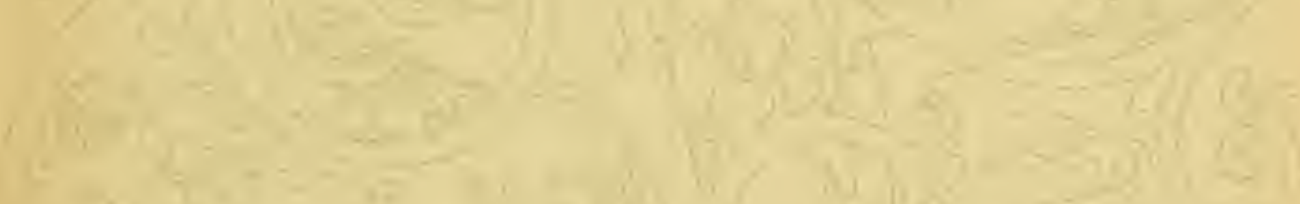

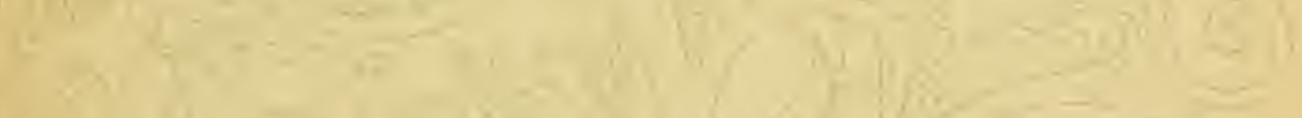

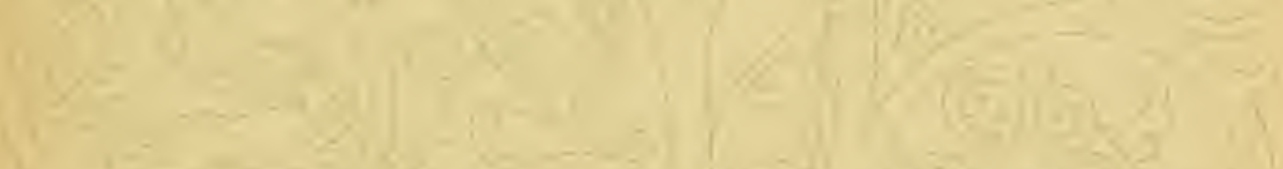

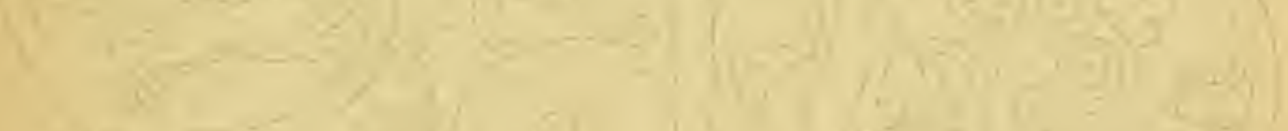

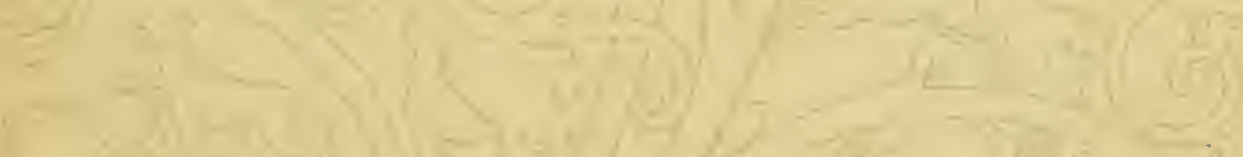

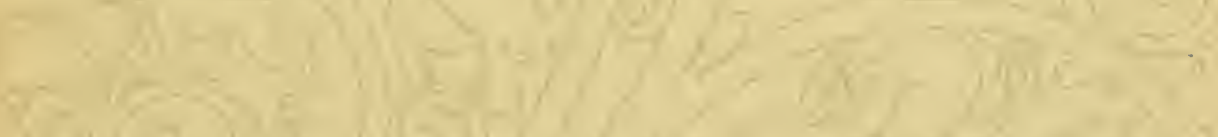

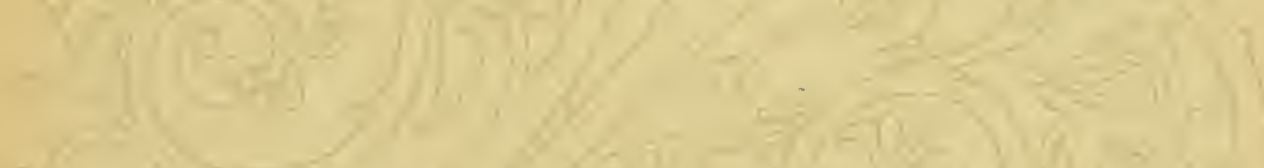

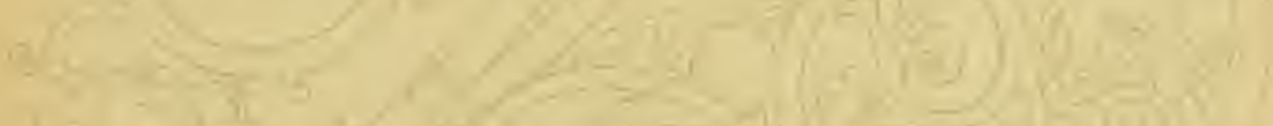

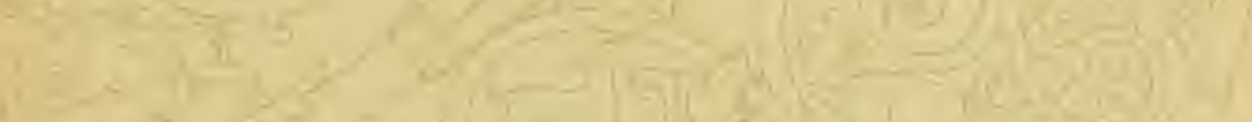

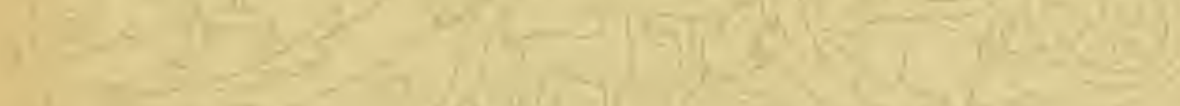

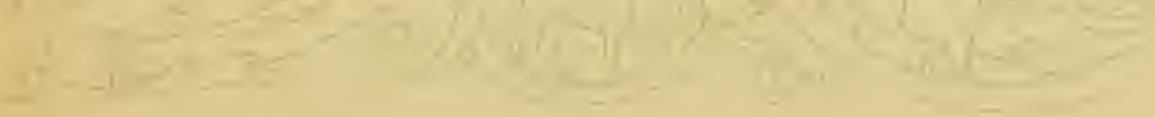




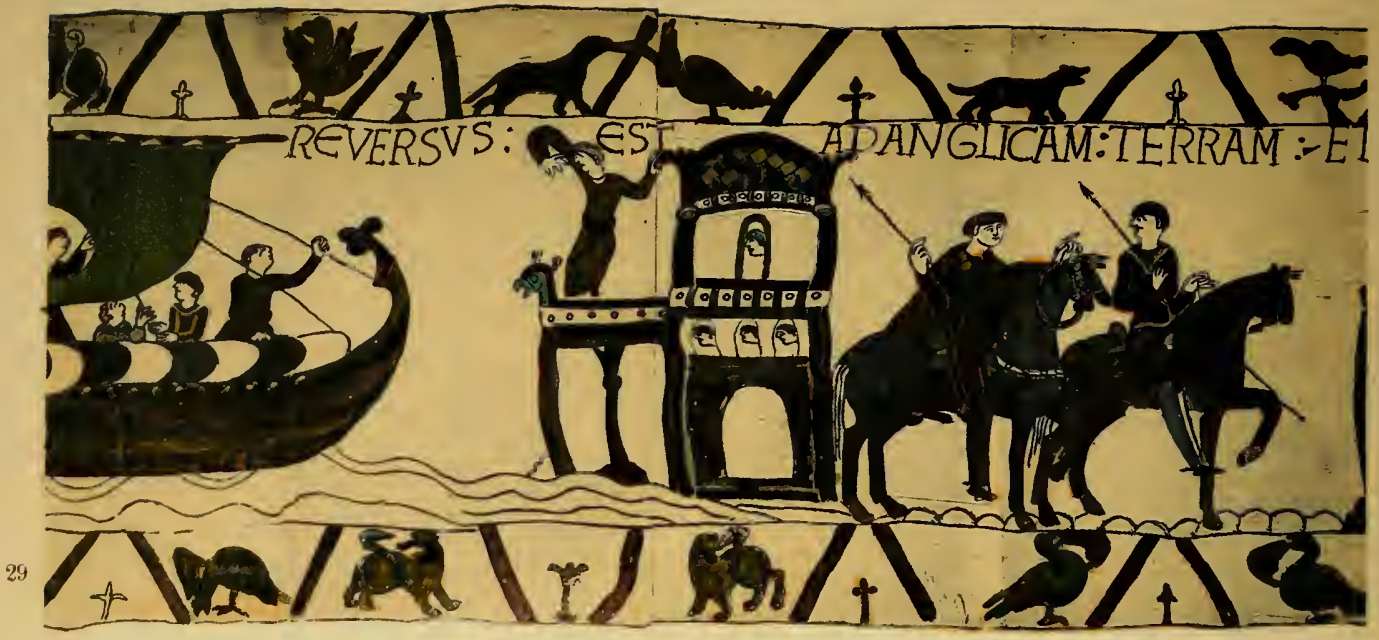

solemnity of the occasion. Harold swears with a hand upon either reliquary set upon two neighbouring altars for the purpose of the oath. It is true that the inscription upon the Tapestry tells us nothing of what he is promising upon oath, but we are quite safe in presuming that the story follows Wace and that he is promising the crown of England.

It is, of course, the chief matter of historical dispute in the whole business whether Harold did make that promise or no.

In the next two panels $(29,30)$ Harold crosses the sea, touches English land, and comes again into the presence of his king, Edward. The cpisodes are not very striking. Perhaps the most remarkable is the conventional building with a sort of pier thrust out into the sea, from which a look-out man watches for the fleet and from the windows of which its arrival is also watched. This building makes the division between the first and second of the panels. It is remarkable that we have no written evidence of this interview between Harold and Edward immediately following his landing; but it must have

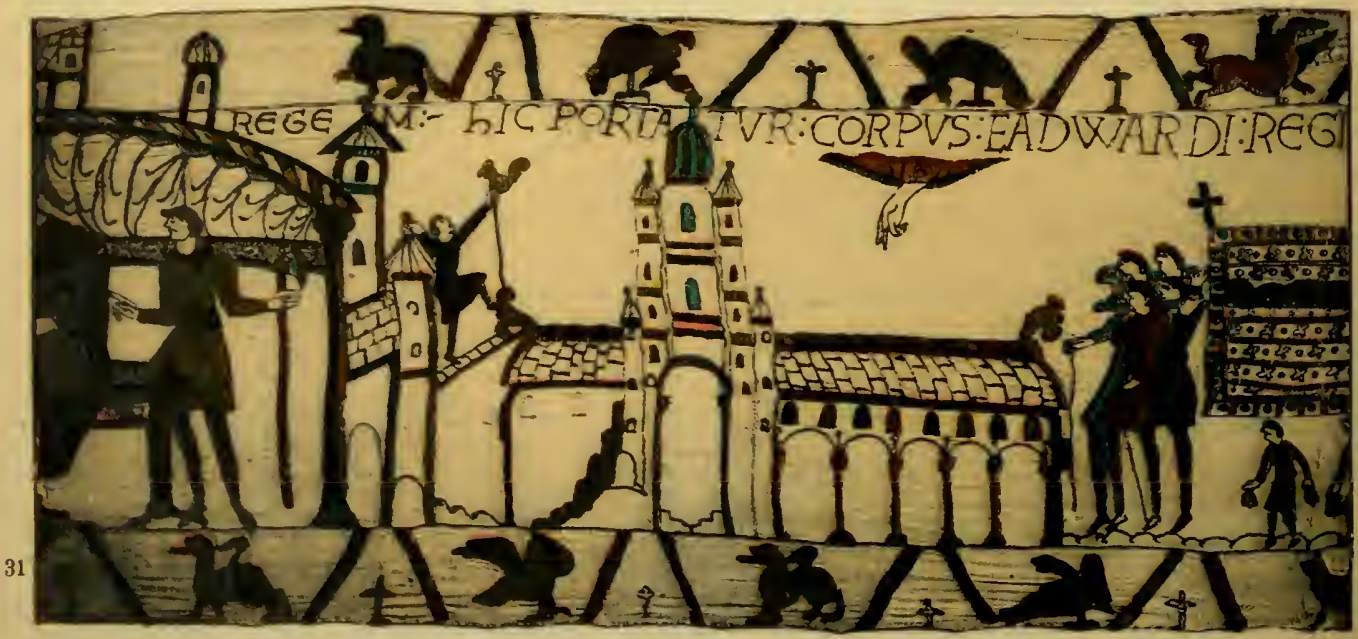




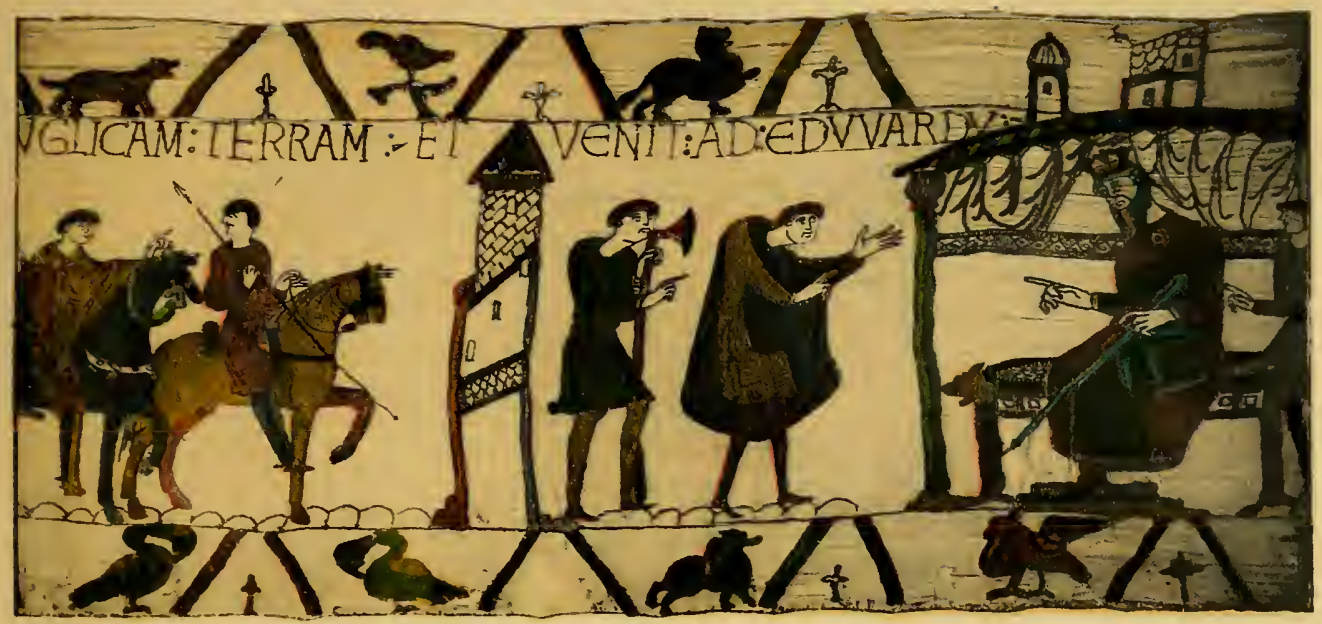

30

taken place, and evidently contemporaries took it for granted.

The next two panels ( 3 I and 32 ) are a very curious instance of that reversing of the historical order by the Tapestry, of which we have already seen a minor example in the case of the messengers sent by William to Guy of Ponthieu. What the artist desired to do was to tell, as a separate little story, the death and burial of Edward; but he conceived of it as an episode running from right to left, and the result is that, in the order of the Tapestry, we have the burial actually coming before the death. Take the two panels separately, read them from right to left, and you get a consecutive story; Edward upon his death-bed, in the upper part of the canvas, is speaking his last words to his lieges with the women and the tonsured priests about him. In the lower part he is represented dead. Then, in the second part, to the left, you have the body carried to Westminster Abbey, with acolytes ringing bells and a retinue of tonsured priests. Perhaps the hand appearing from heaven above Westminster Abbey is designed to indicate the sanctity of the

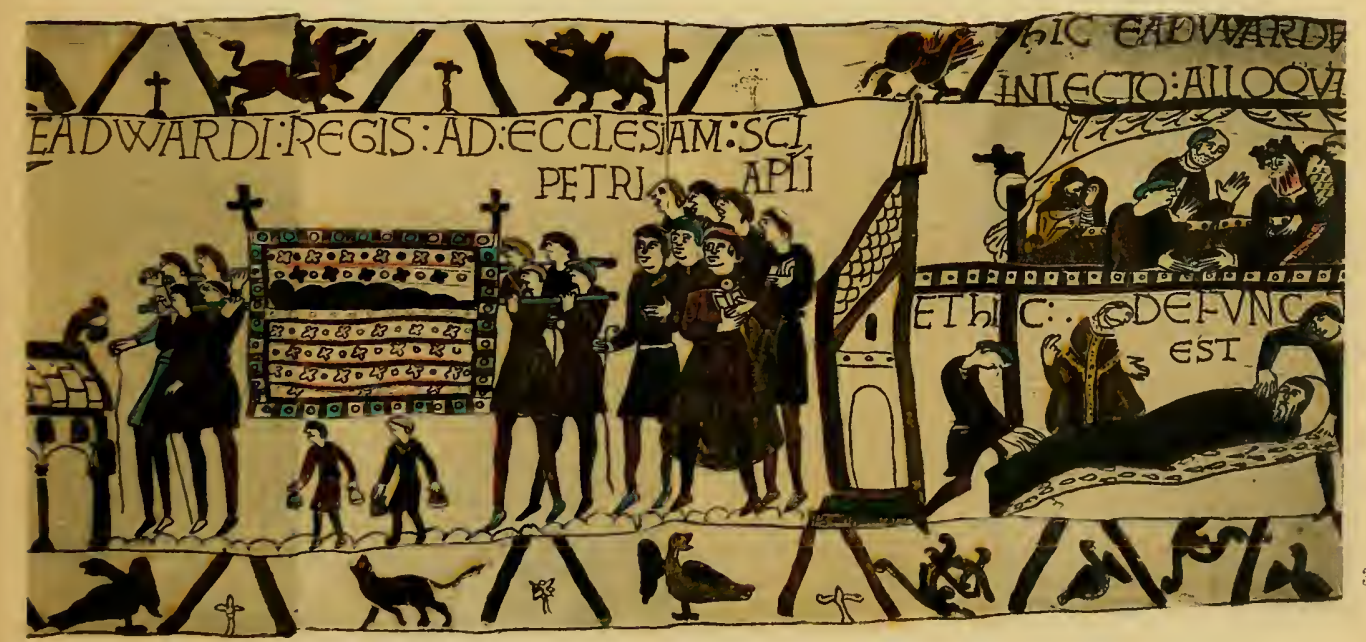




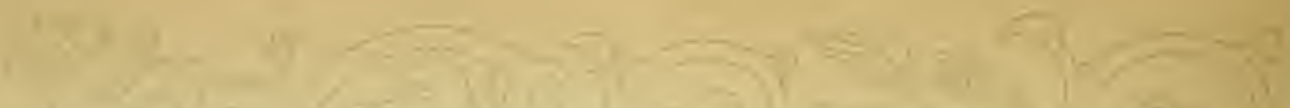

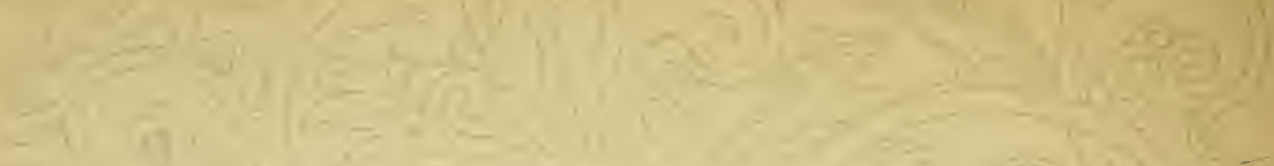

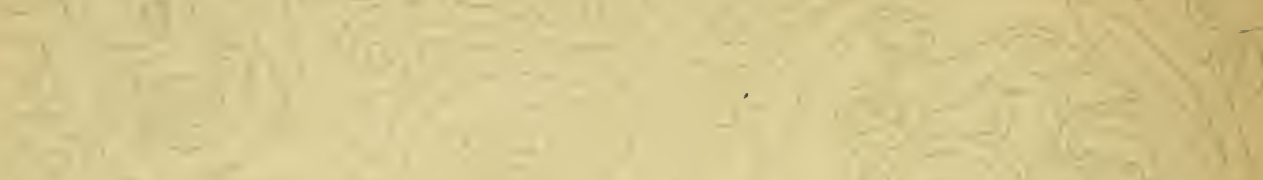

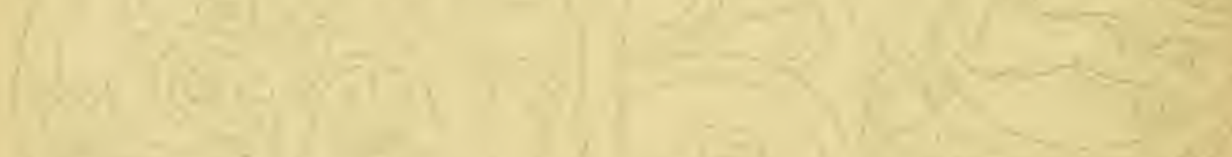

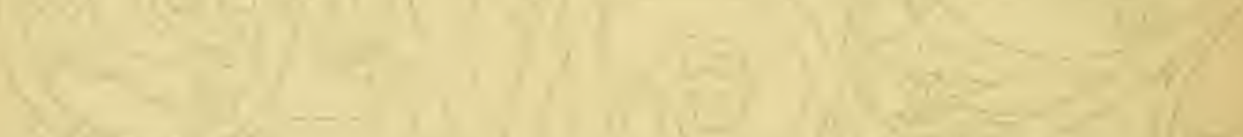

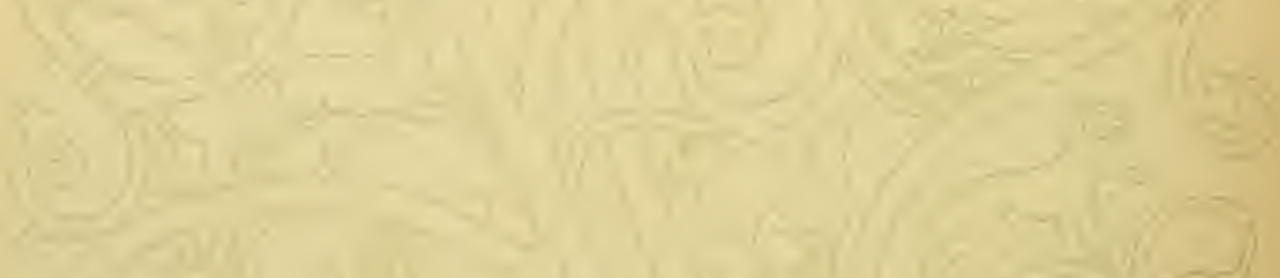

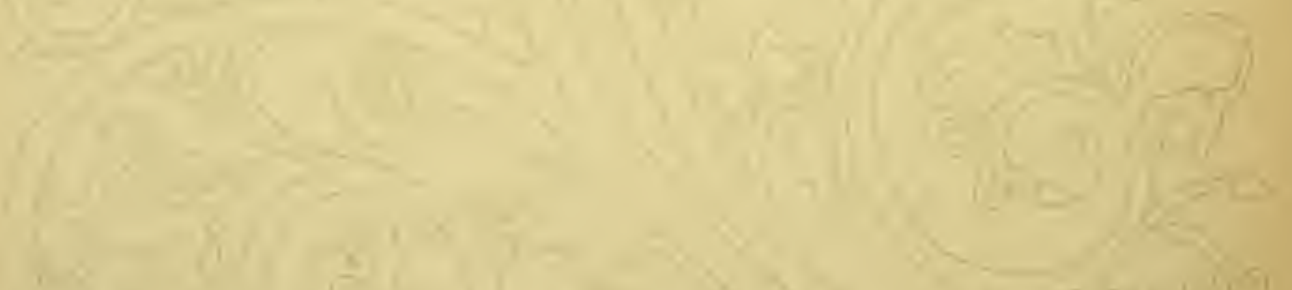

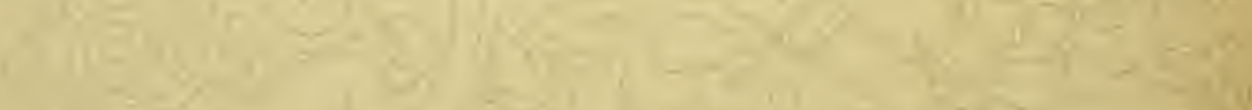

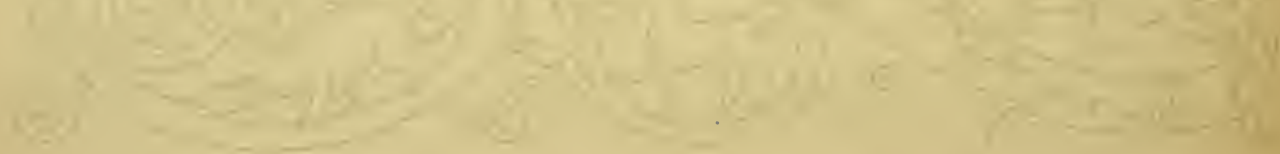





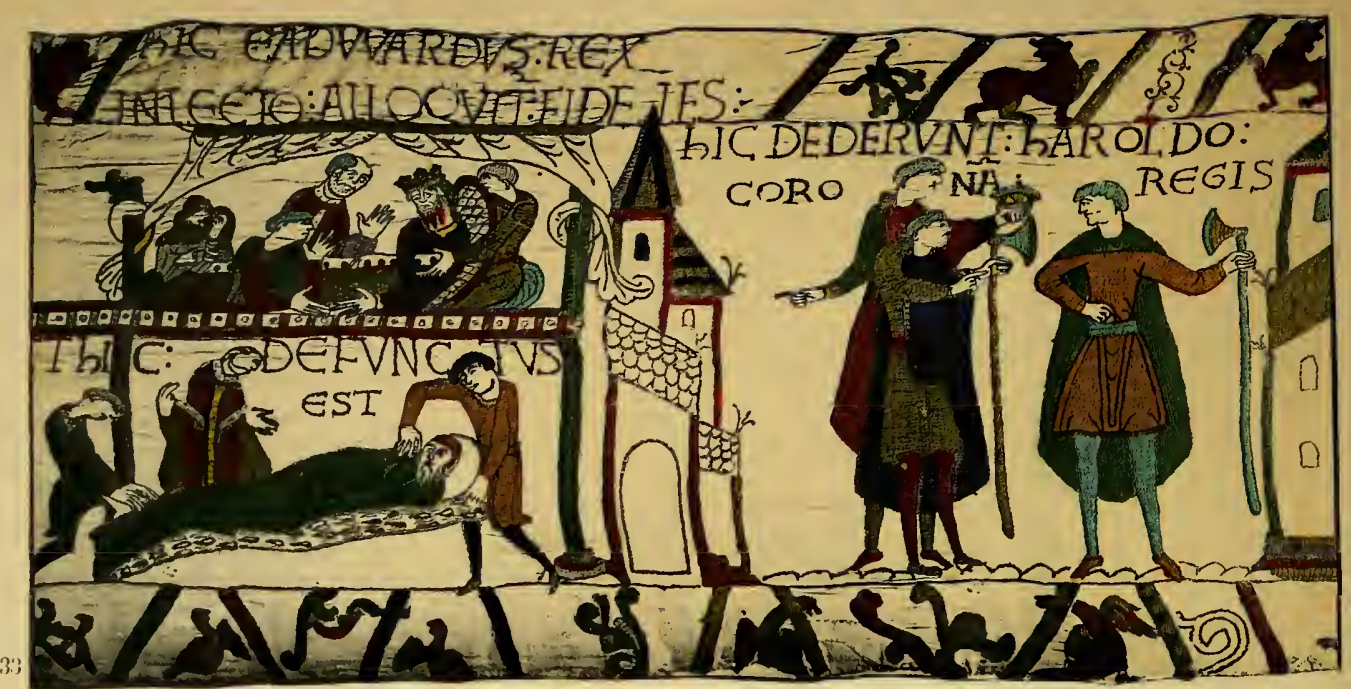

king. Nowhere does the Tapestry follow Wace more closely than in these episodes, and even if we had no other evidence to guide us this portion of the 'Tapestry alone would be almost sufficient to establish the connection between the poem and the embroidery.

Then comes the turning point in the story, as in the series of pictures, and it has been designed to come not quite half way in that series (the $34^{\text {th }}$ out of 76 panels). Harold is offered the crown of England: accepts it, and appears enthroned and in full regalia. To the left you have two messengers holding the typical battle-axe of the Saxon army, and a third messenger pointing towards the death-bed of Edward ${ }^{3}$ with his right hand, and with his left holding forth the crown. Next you have the same symbolism completed with the picture of Harold enthroned as a king. The early Middle Ages were careful to an extreme of their conventions, which were centuries old and which linked them with Rome. To distinguish by conventional signs between a king and a man who might be an actual

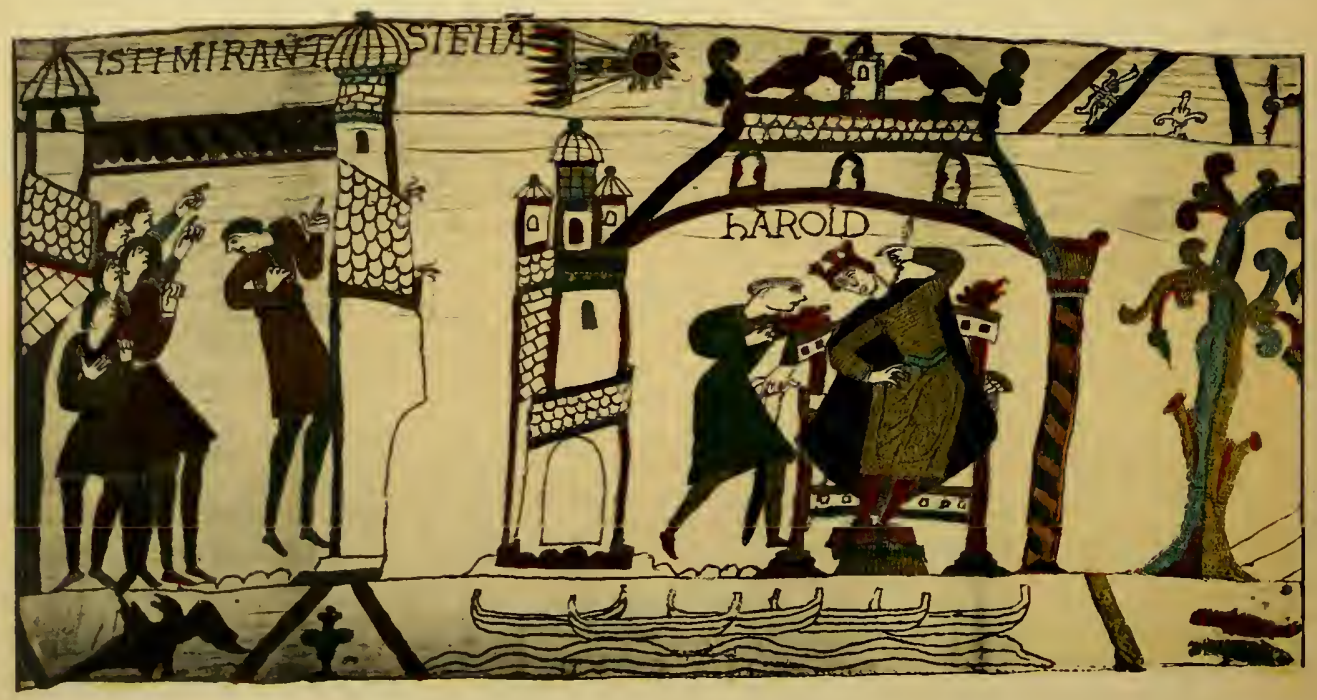




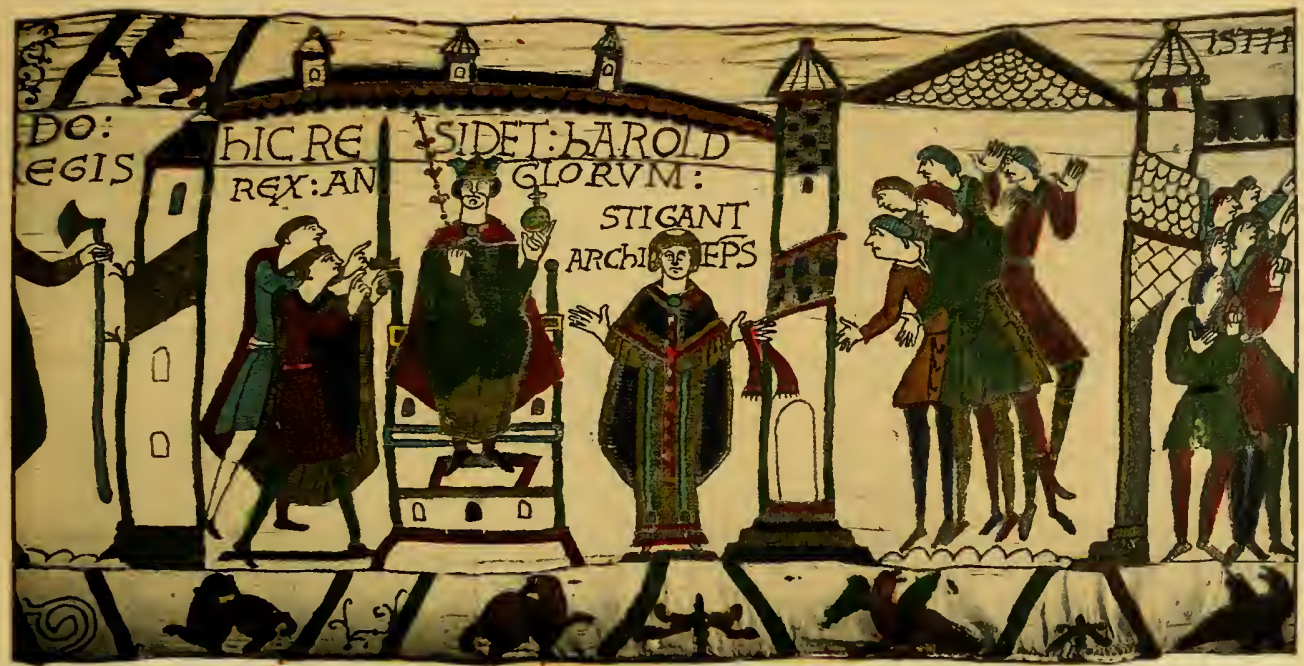

ruler but not king, to distinguish the various rituals of various decisive ceremonies, the various accoutrements and the rest, was with them as strict a matter as spelling is with us-I could not put it more strongly. When, therefore, Harold is represented with the orb and cross, the sceptre and the crown, and the long vesture of royalty, seated on the high throne, and presented with the temporal sword, that picture is equivalent to what some long emphatic statement would be in modern times that such and such a man had committed himself to such and such a political action. It means "See here! Harold did really seize the throne!" Scholars have made some play over the presence of Stigand, the Archbishop of Canterbury, in this panel. I may briefly put before the reader what I make of this figure. In the first place, it is a divergence from Wace, who does not mention Stigand. In the second place, it shows Stigand's rôle as the Ecclesiastic responsible for the crowning of Harold. In the third place, we must note that he is called "The Archbishop." Now I put all this together and I presume that when

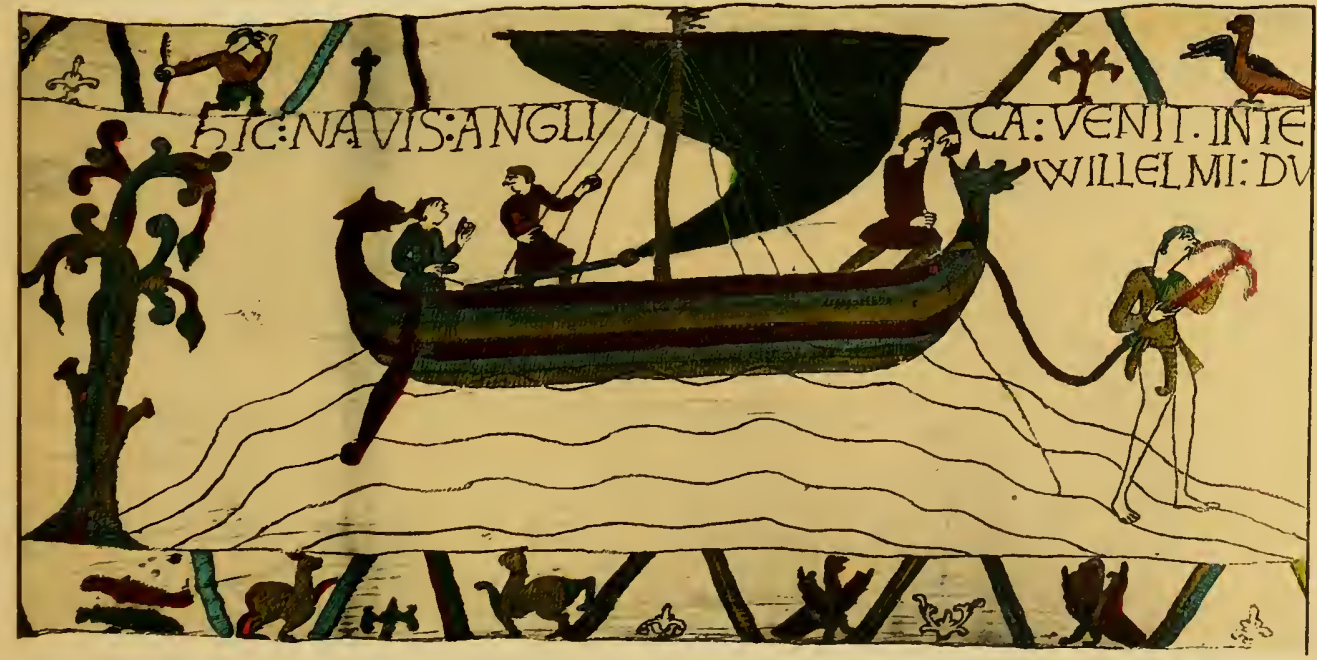




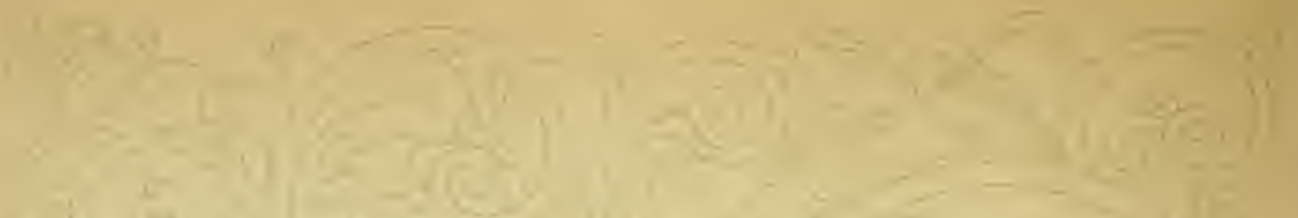

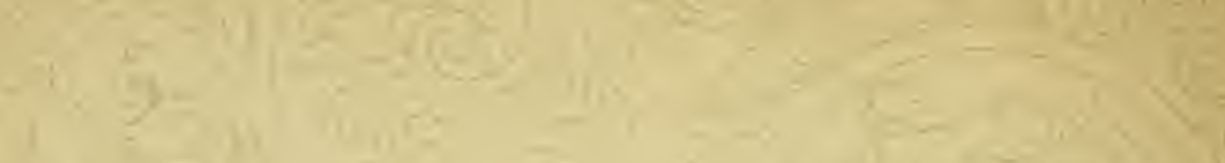

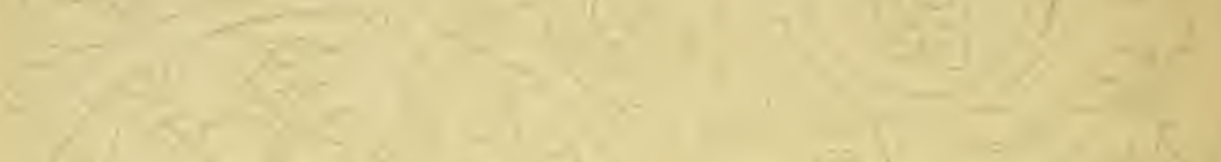

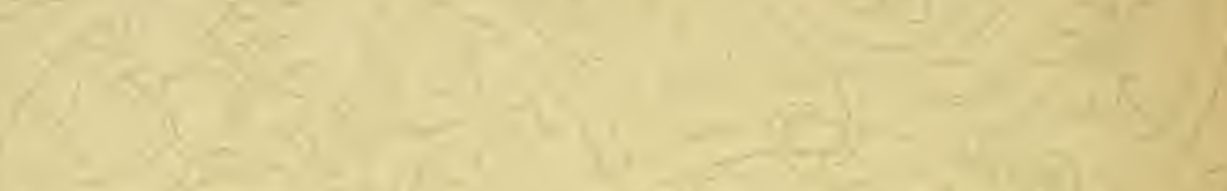

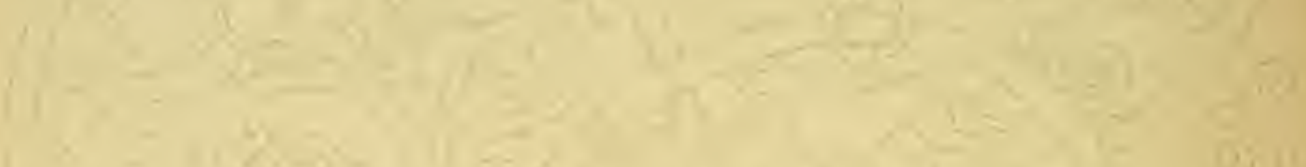

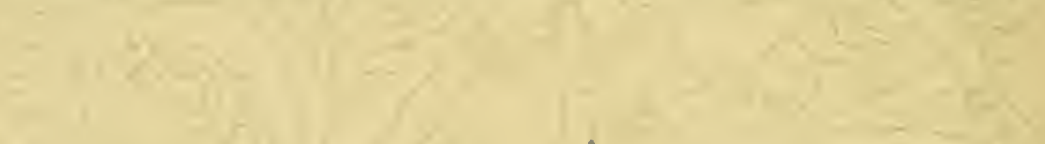

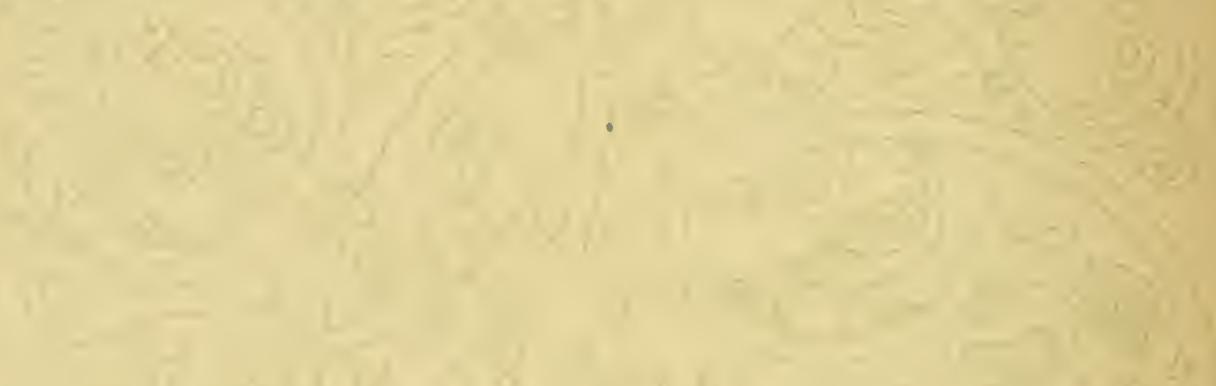

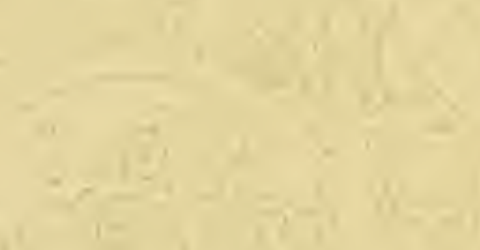

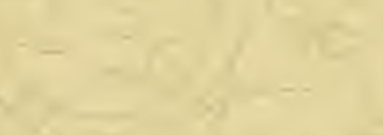

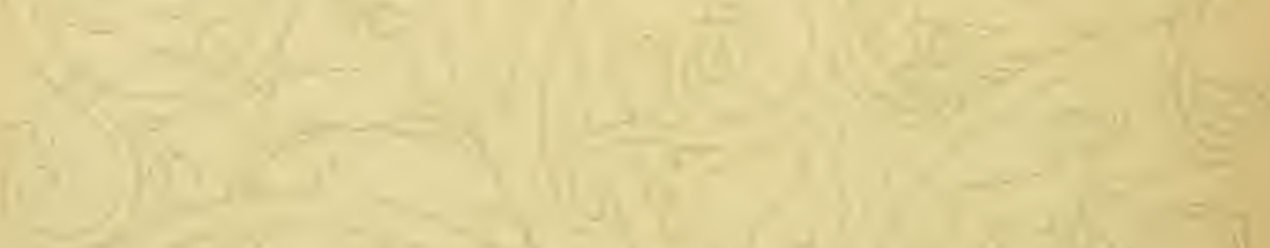

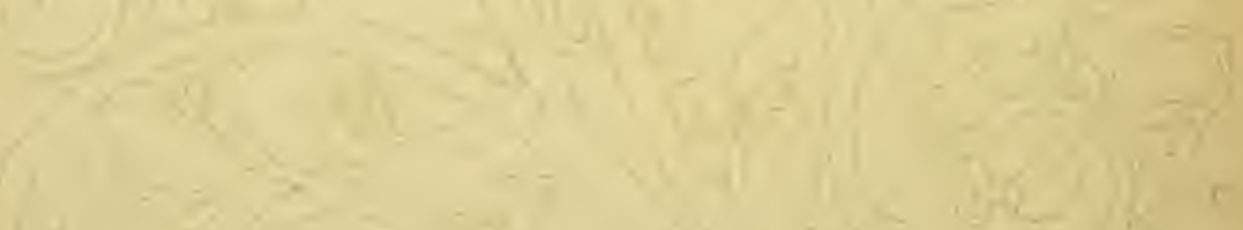

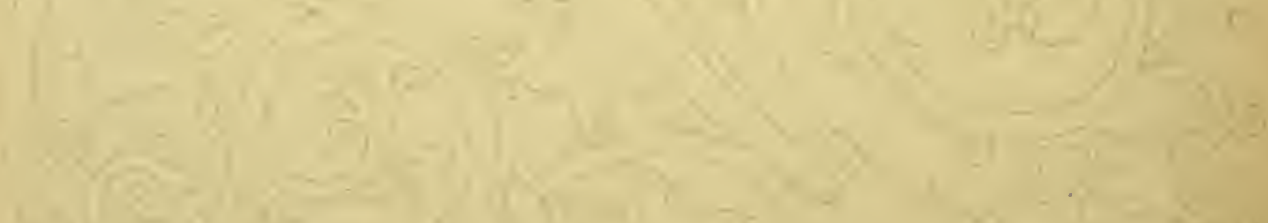

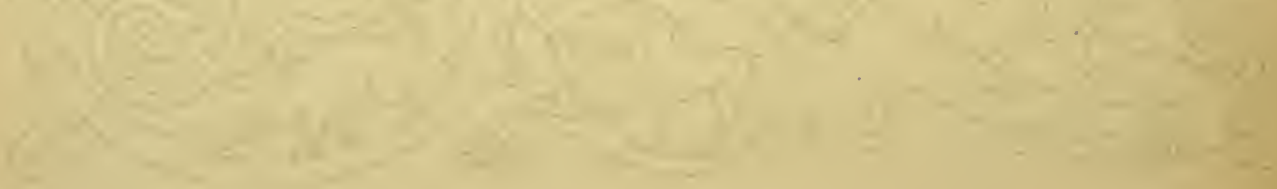




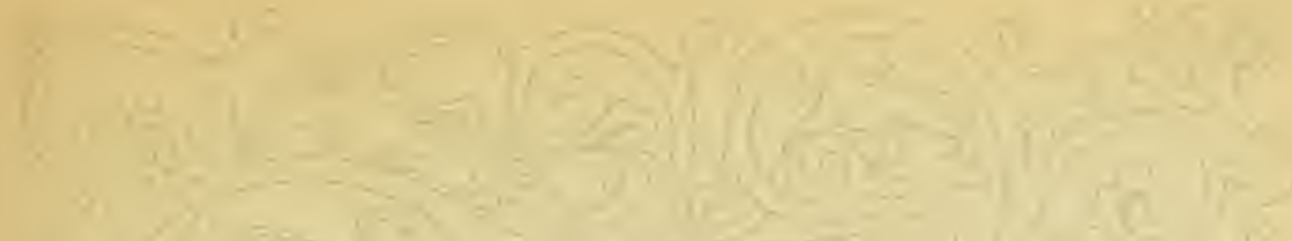

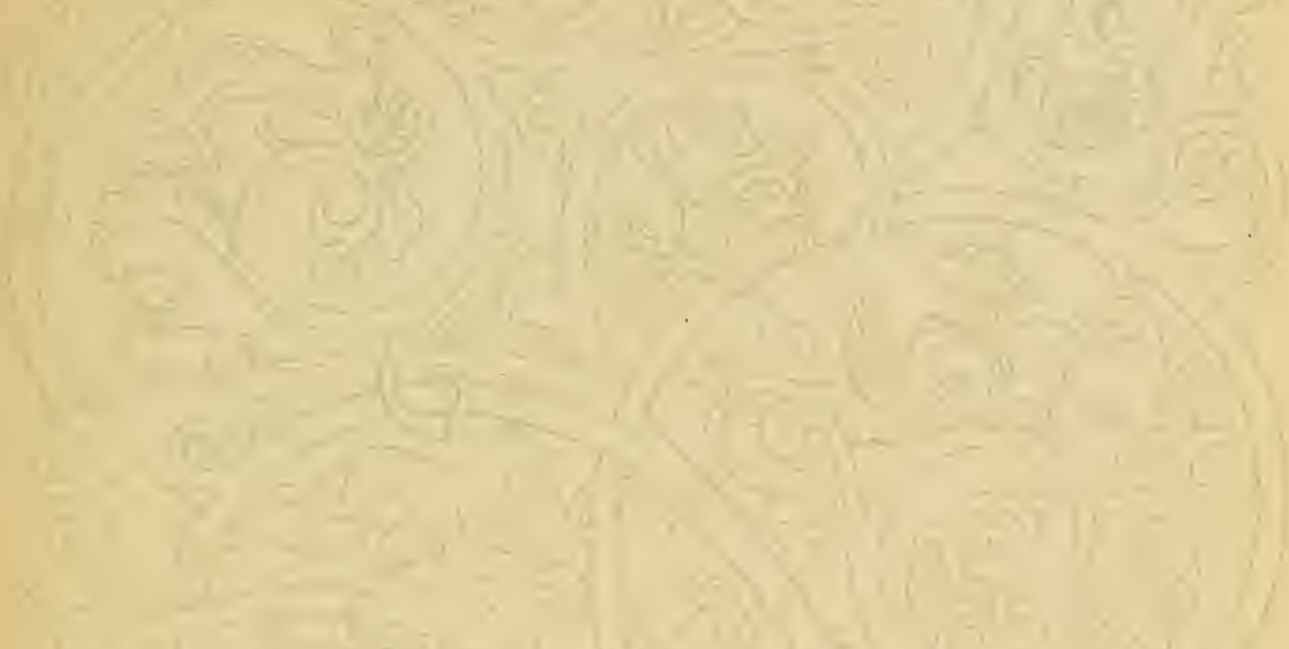

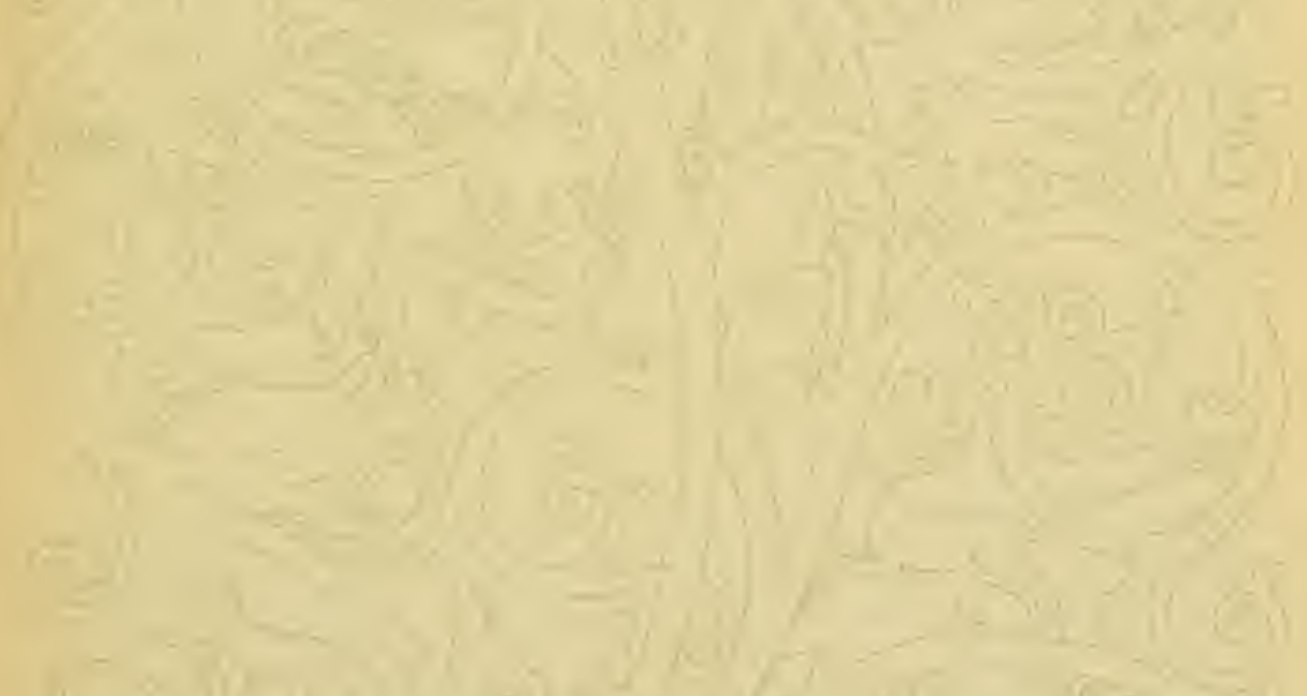

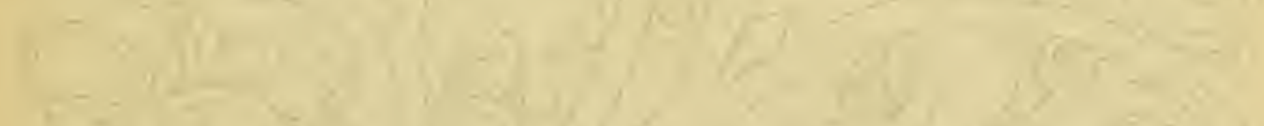

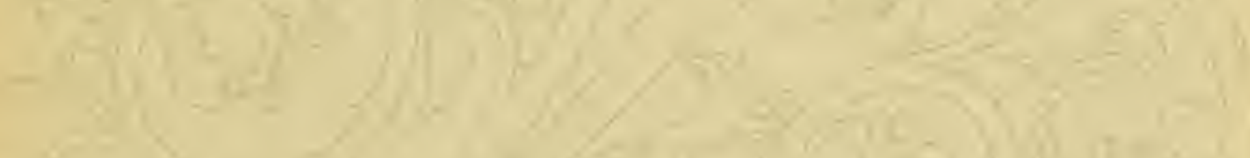
-

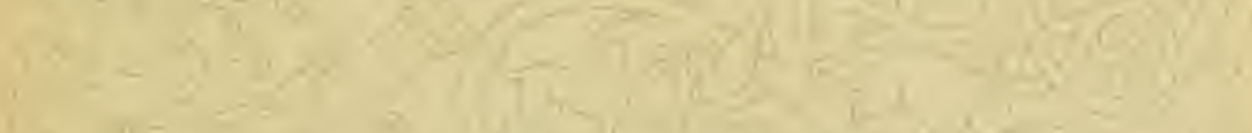

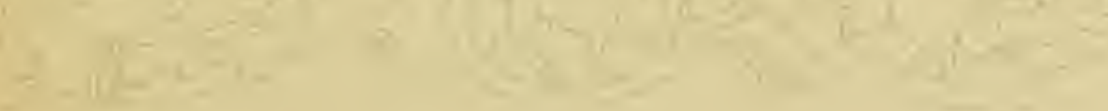




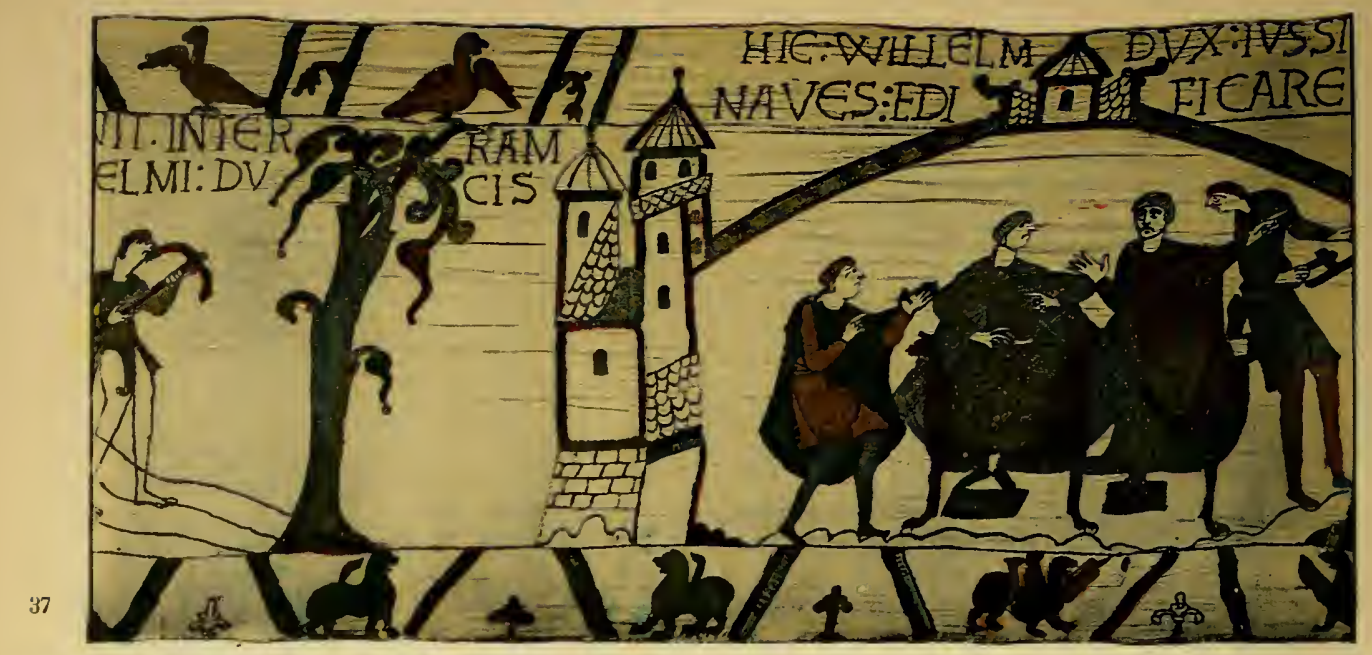

the Tapestry was produced, about a generation later than the Conquest, it was desired to make prominent the fact that a man held to be schismatic was responsible for the Coronation, and that the same motives which caused the making of Harold the villain of the piece throughout caused the author to bring Stigand well forward. One or two critics have suggested that Stigand's irregular position would have prevented a foreign, or a later, artist from calling him "Archbishop." That seems to me unhistorical. True, William of Malmesbury and every orthodox writer thought Stigand no true Archbishop of Canterbury. He was a "false Archbishop" in their language, but for all purposes of general description he was the Archbishop all the same. Whether Stigand did, as a fact, crown Harold or not is a matter for historical discussion; but it is certain that those who designed the Bayeux Tapestry wanted it to be thought that Harold, a perjurer and a traitor, had been crowned by a man who, in the heat of St. Gregory the Seventh's reformation of the Church, would be odious to public opinion.

Between this panel and the next are a group of figures representing

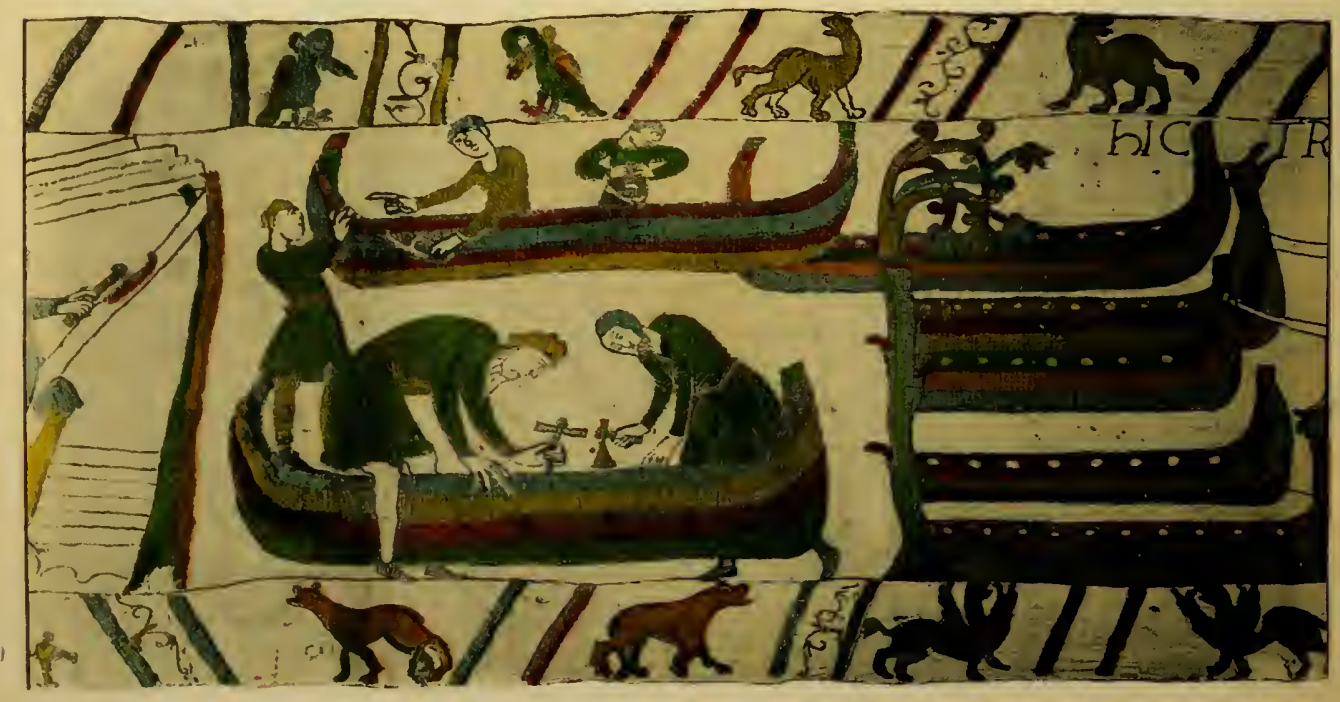




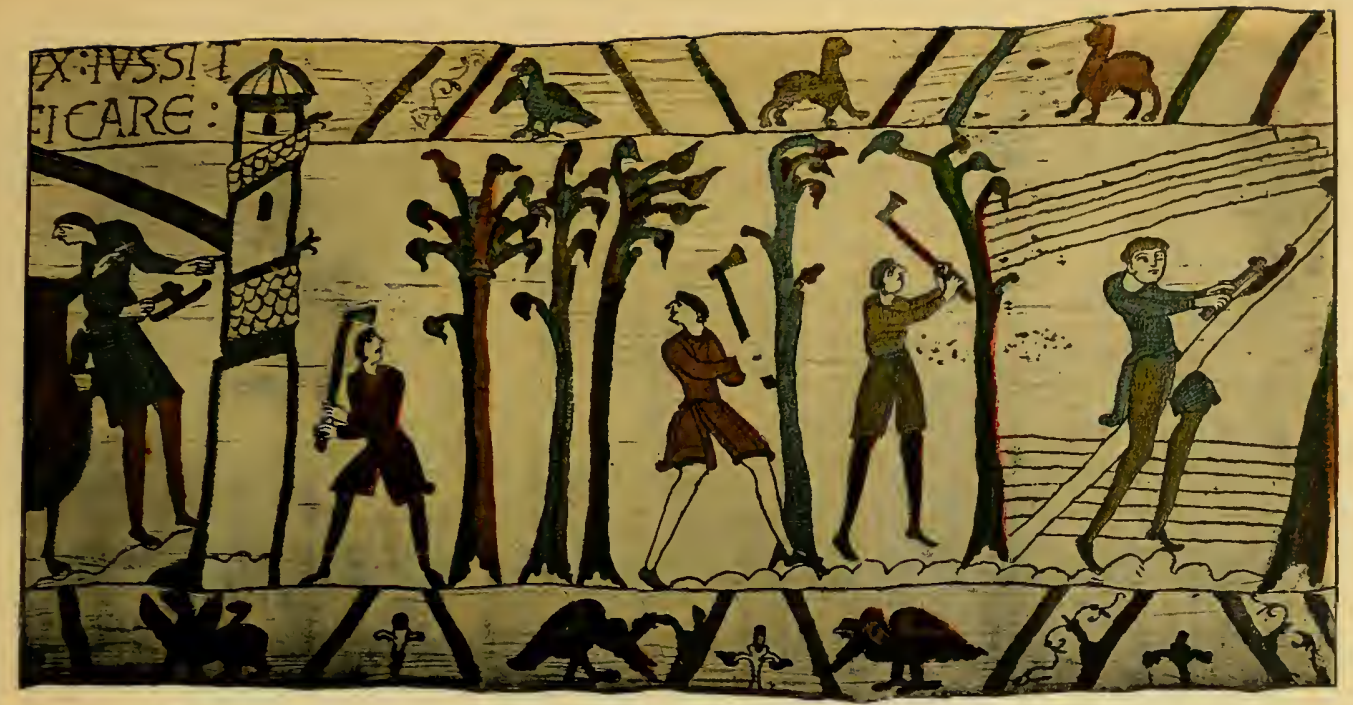

"the populace," who do homage to the new king. Then come two panels, separated one from the other and dividing, as it were, the first half of the Epic from the second. These two panels (35 and 36 ) give the comet, a figure of Harold, and the arrival of an English ship upon Norman land.

It was just after Low Sunday of the year I066, on the Tuesday, I think, that a great comet was seen in France and England. Modern. science has affected to regard it as Halley's Comet, which it may possibly have been-but modern science should remember that the variation of these bodies, and the confusion of our evidence upon their movements in the remote past, gives no one a right to certitude in such a matter. Nor is it of the least importance. So far as we can fix a date, 25th April I066 seems to have been the moment when this star was first seen. At any rate, it was an apparition which vastly moved the opinion of Europe at the time.

What the artist meant by the episode with the single word "Harold"

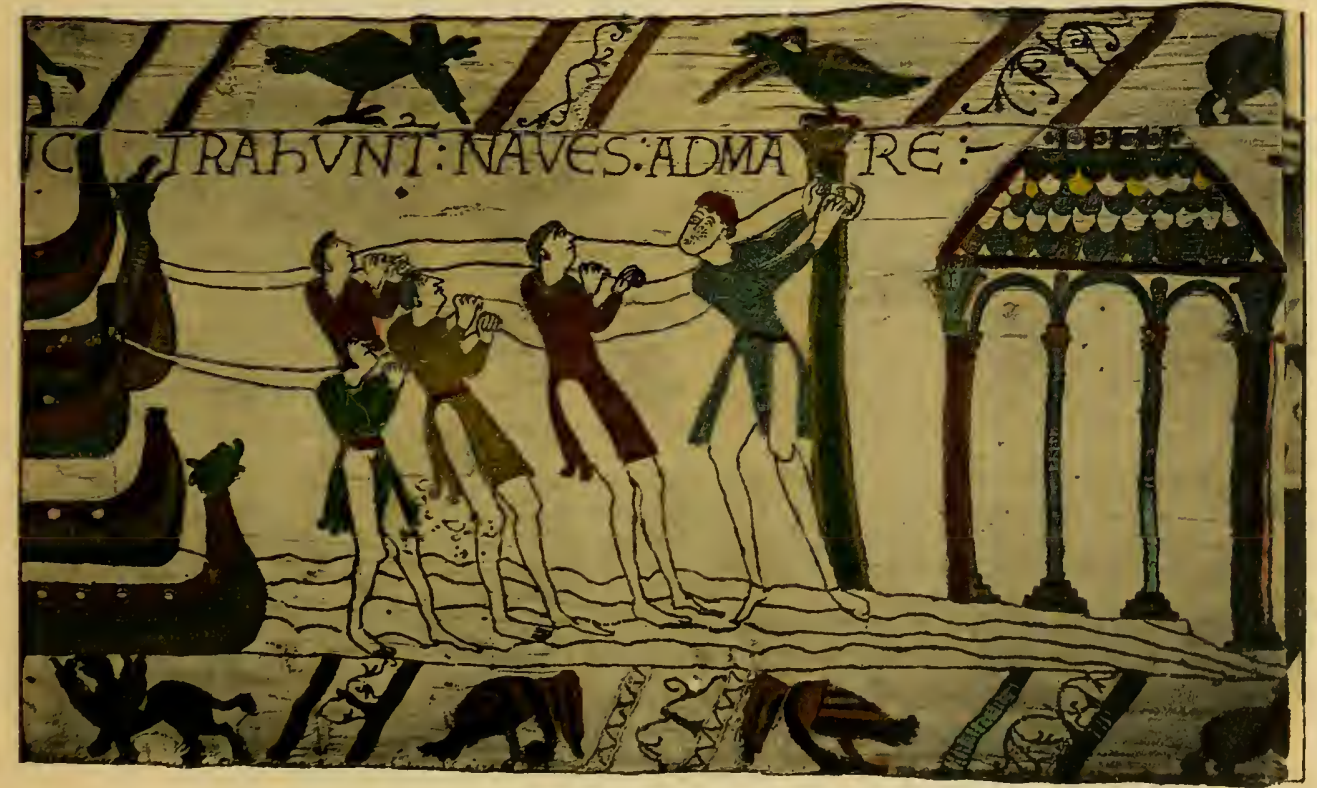




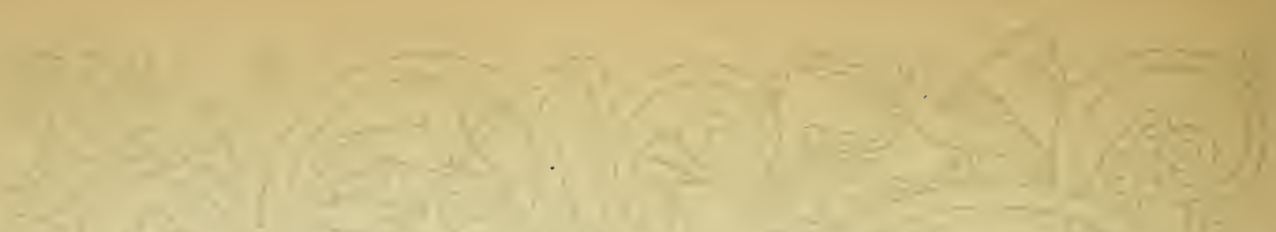

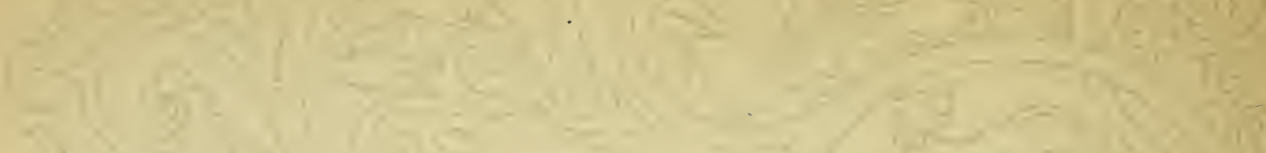

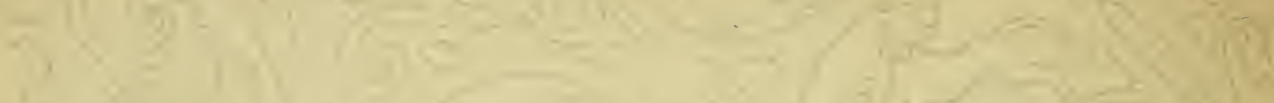

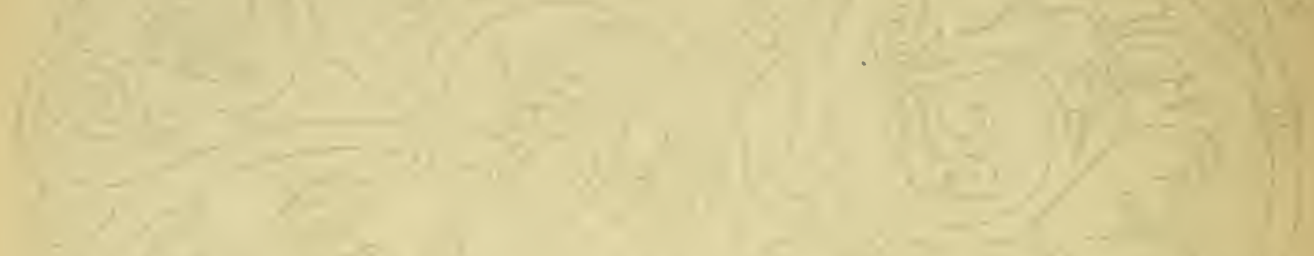

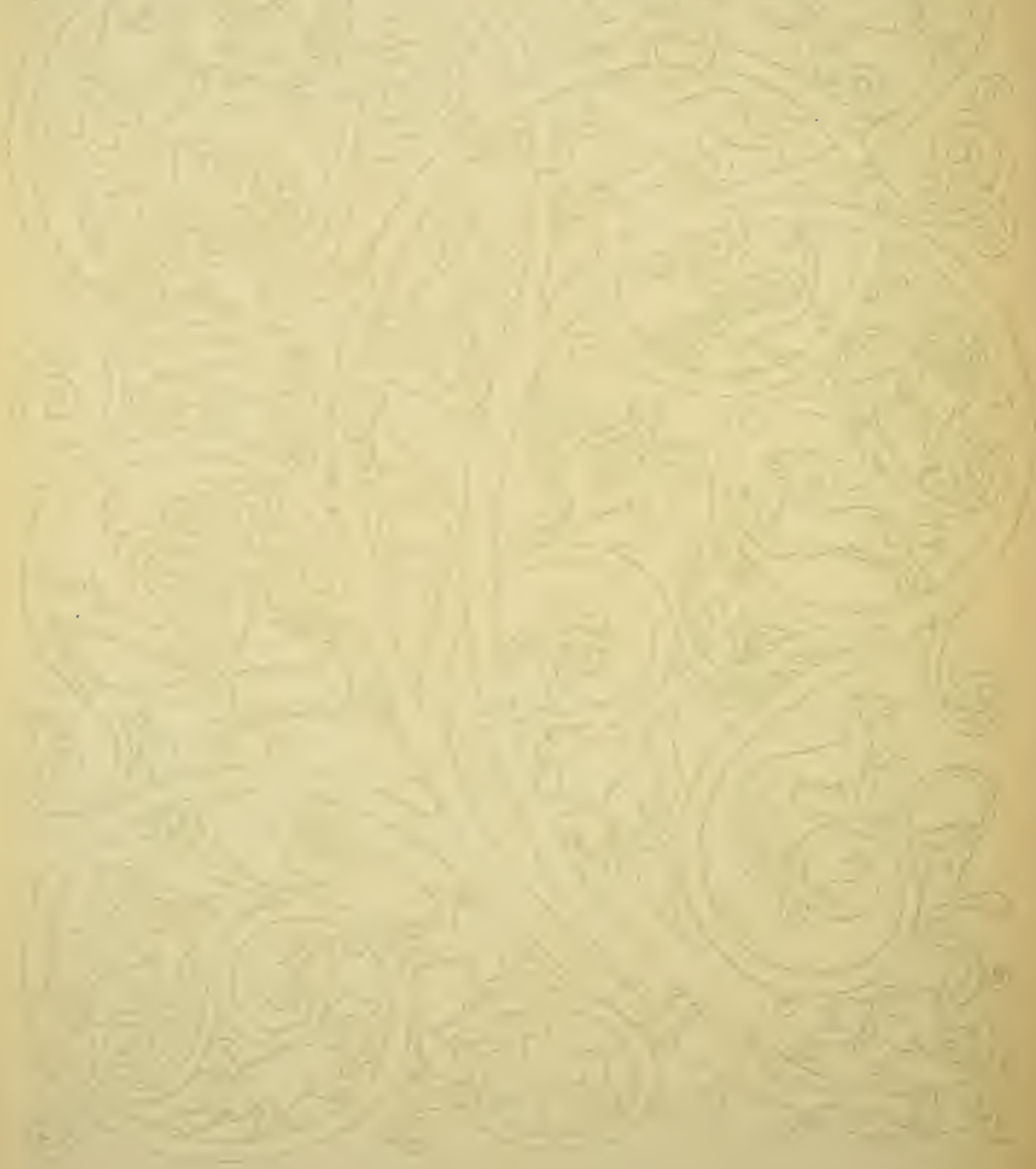





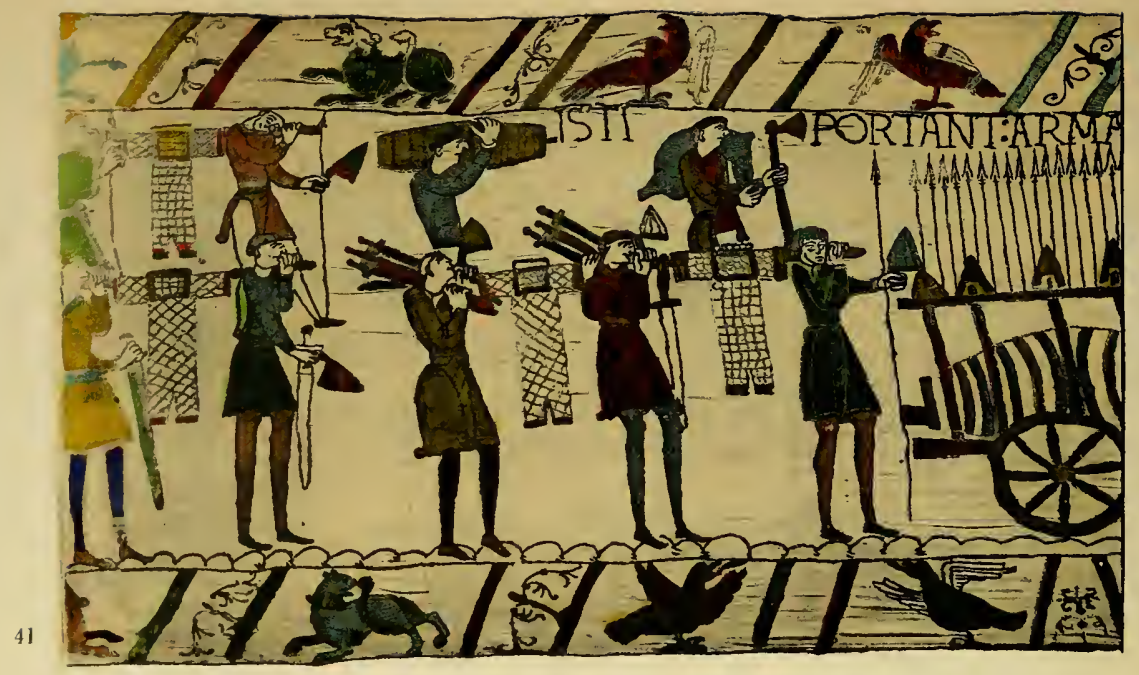

does not seem to me doubtful. You have there the conventional marks of the palace, the king in the full garb of his kingship but partially armed; a messenger, and beneath him the hull of ships. He is awaiting the advent of the invaders. He knows that they will come.

The second panel of this group represents the coming of an English ship to Normandy, and beyond that we are told nothing. But we do get some light upon this panel from Wace, who tells us that a ship came from England with a special message to the duke-it must be presumed a private message sent to him at his own orders informing him of the death of Edward and of the usurpation (as William would regard it) of Harold. We have all the conventional symbols of the landing of a ship, but in these it must be specially noticed that few men are represented, and that there are no arms. After this begins the action which completes the whole business: I mean

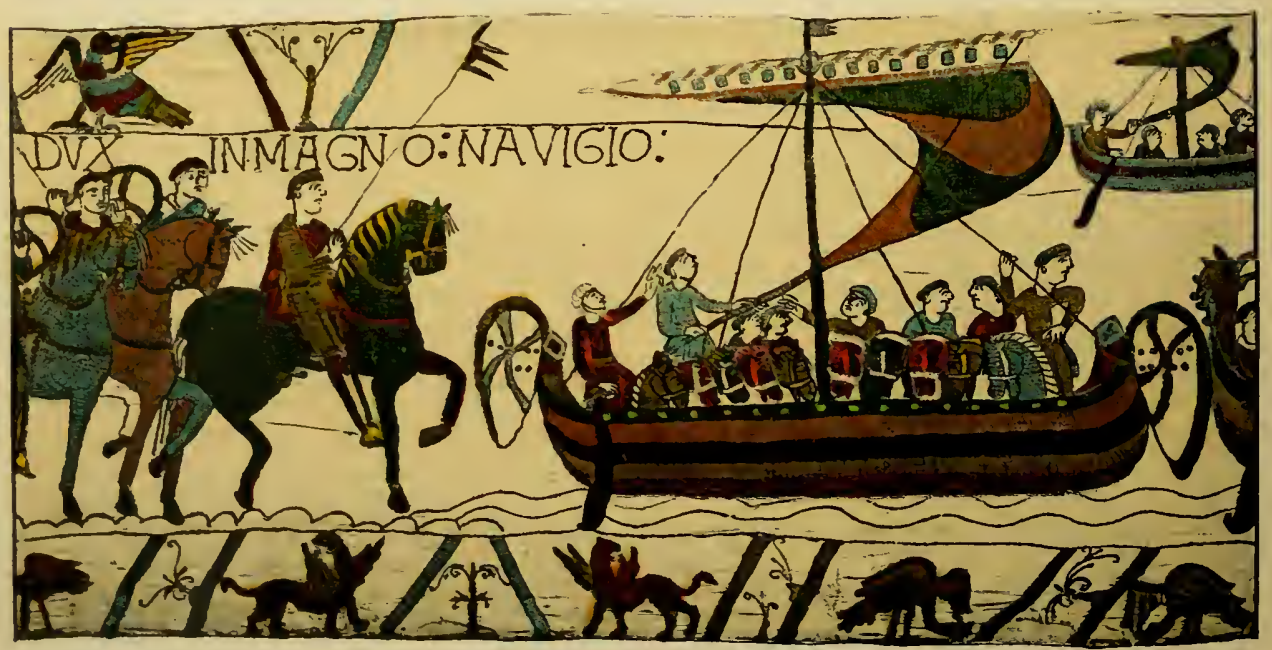




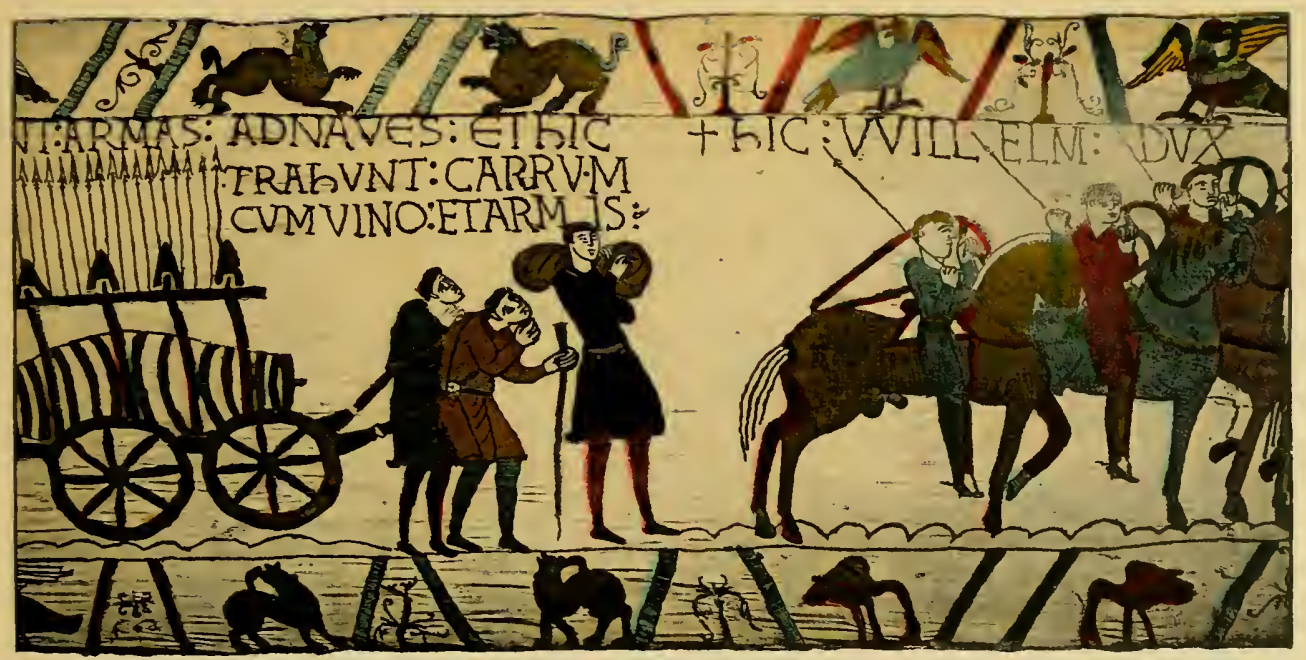

the building and arming of the invading fleet, the landing of the invaders, and the victory that followed.

Of this latter part the first three panels $(38,39,40)$ are concerned with the building and launching of the ships. In the first William orders the fleet to be built. He is seated upon his throne, and is delivering his commands.

Next you have conventional representations of men cutting down trees, rinding off the bark, and making planks. Then you have the construction of the vessels and the dragging of them to the sea from the slips. It is remarkable how little the artist has attempted to symbolise the implements of this industry; the adze and the axe are all that he gives us. The hammer is not recognisable, nor the nail, nor any other thing in the construction of the boats. Following these three you get the provisioning of the fleet, and in this long panel, or rather two panels undivided (4I and 42 ) we must closely

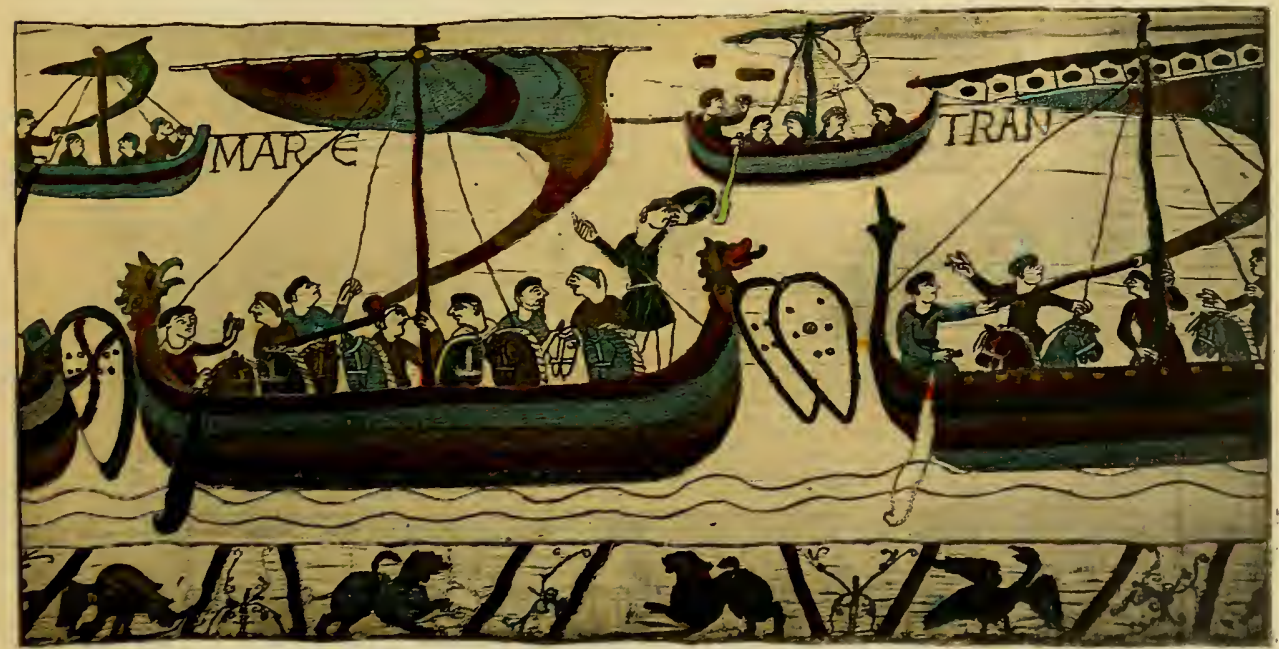




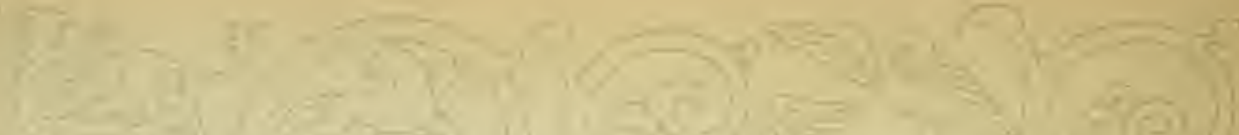

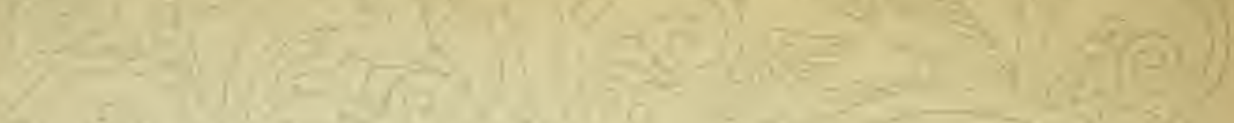

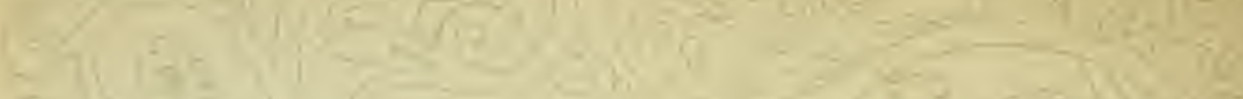

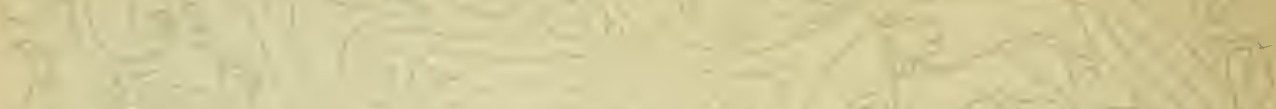

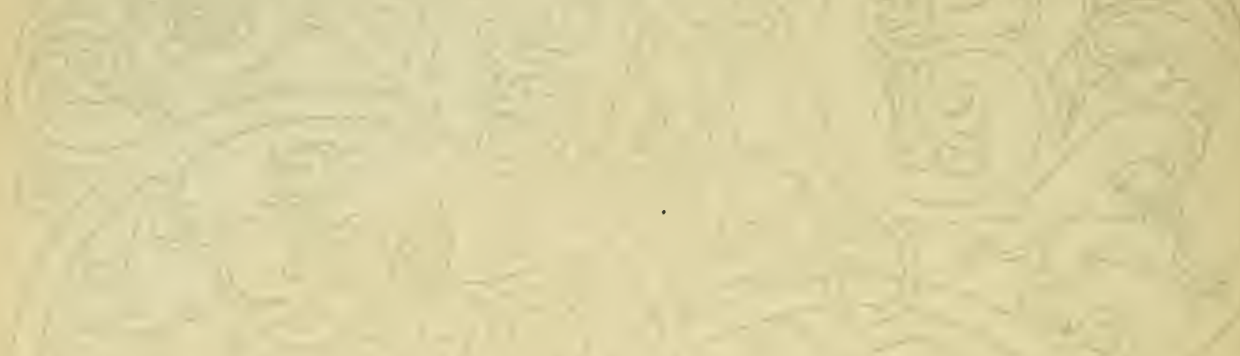

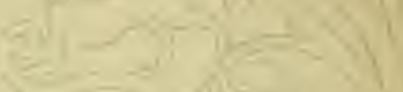

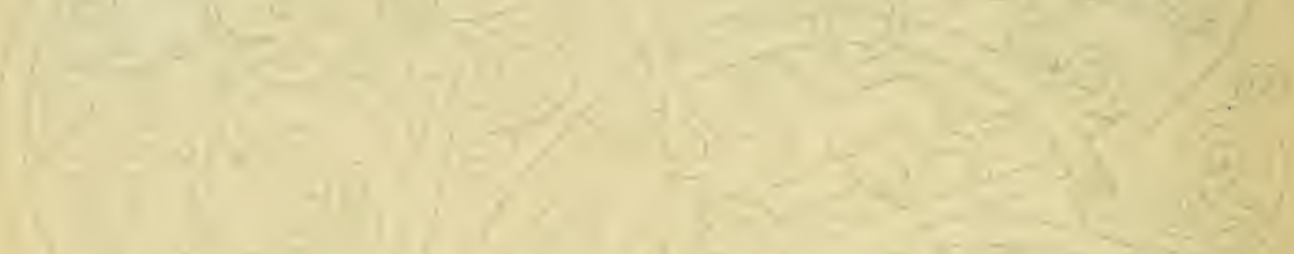
$(-2)$

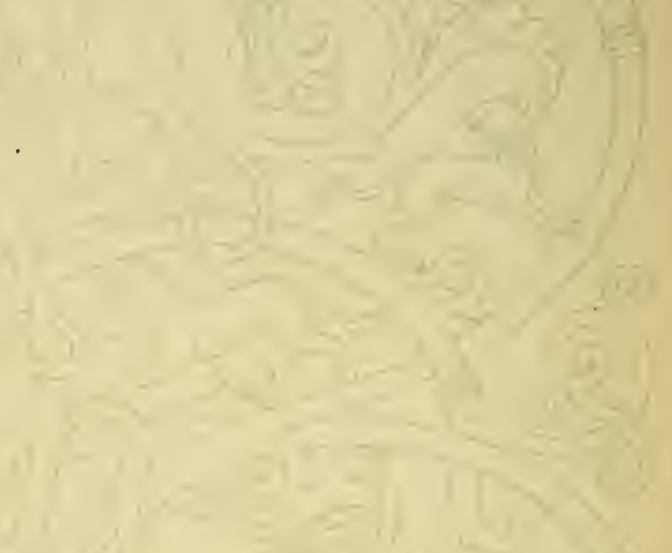

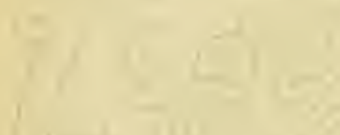

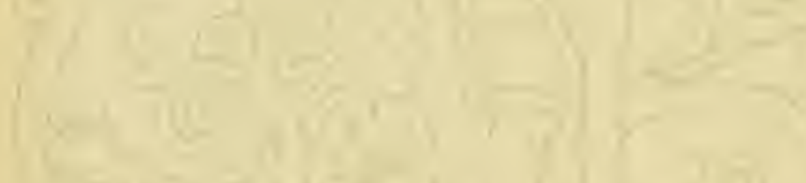

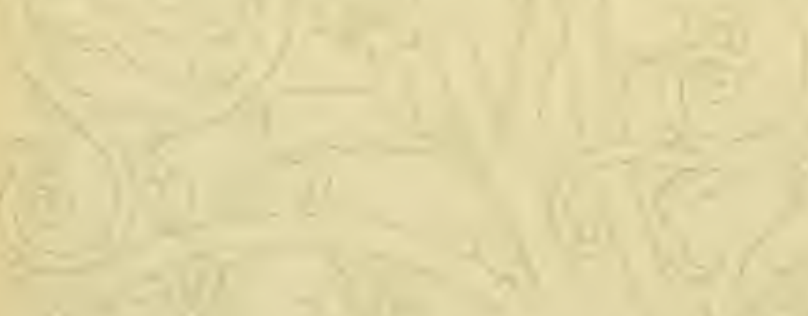

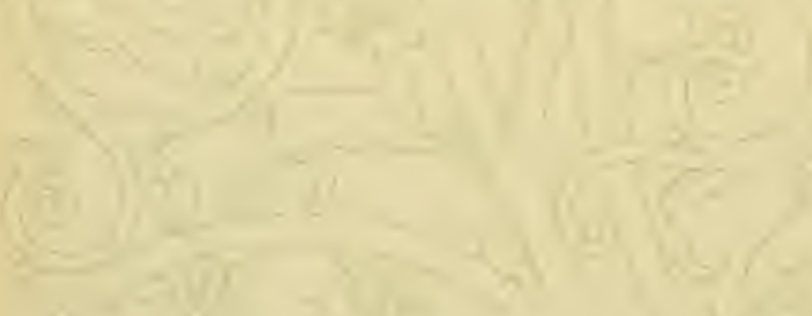

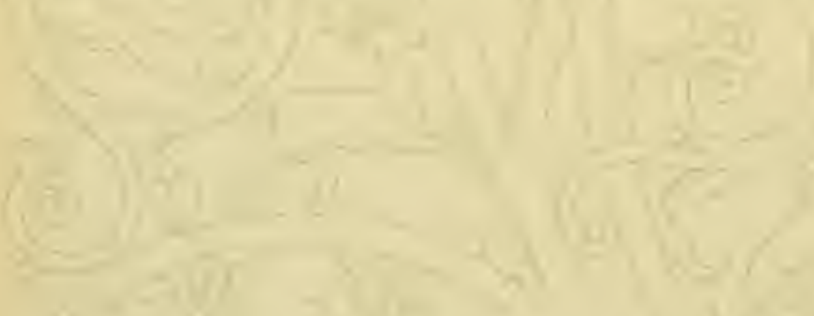

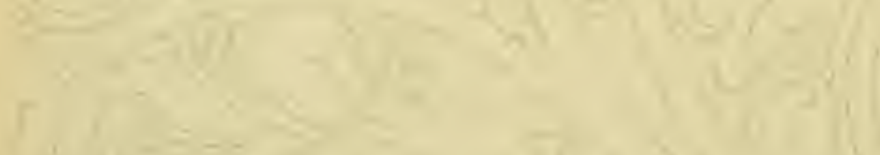

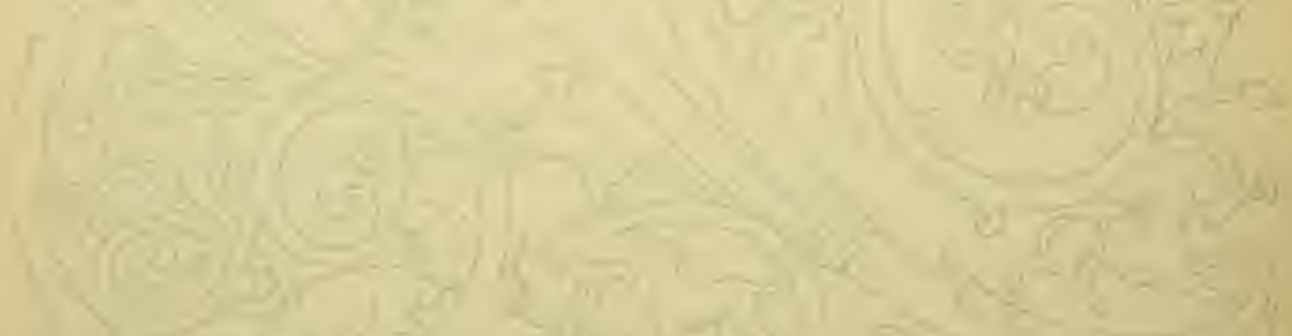

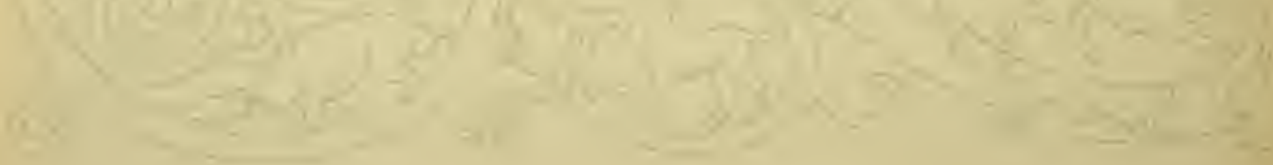





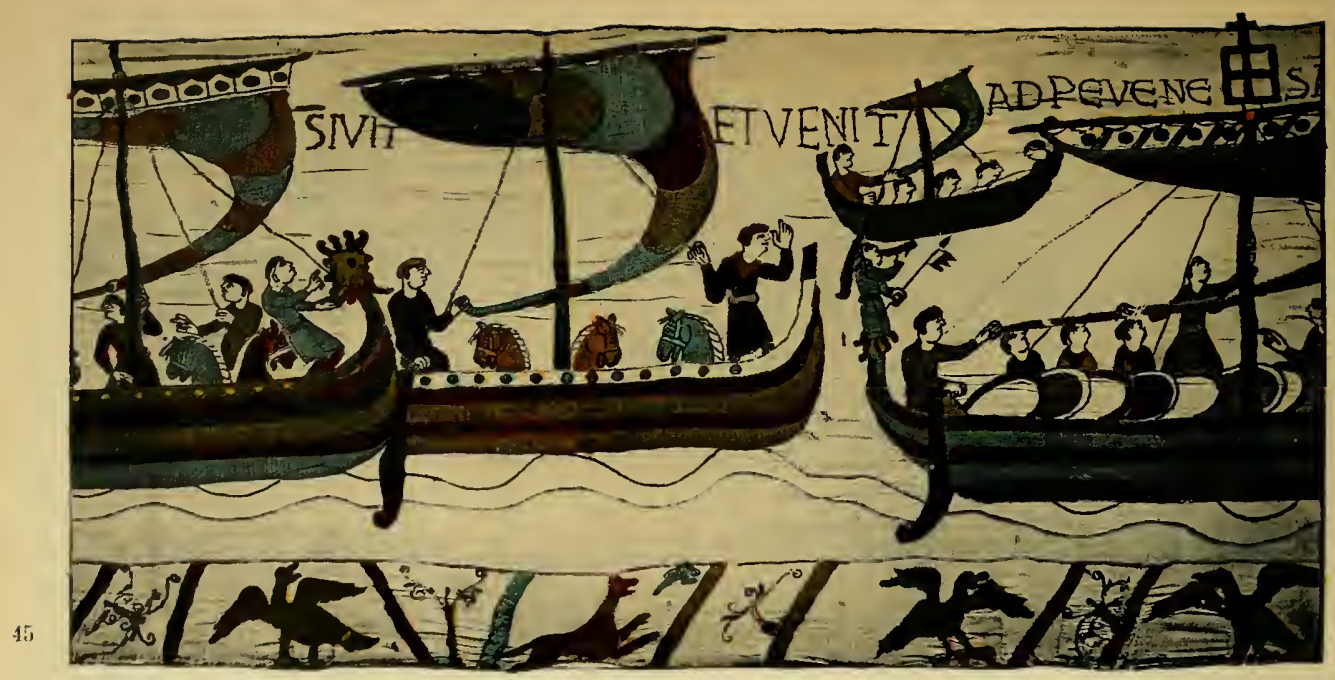

watch the details, for they are of great historical interest. There you will see the servants bringing on board the swords in their scabbards, the lances tied on to wagons, which also bear barrels of wine; over one man's shoulder a wine skin, over another's a small barrel, and, borne upon poles, which bear their weight and stretch them out, the heavy coats of mail for the knights. These panels ended, you have the sailing of the fleet, monotonous and undivided, covering what may be called four panels $(43,44,45$, and 46$)$, though all are continuous. In these the draughtsman has concerned himself to insist upon the number of horses that were carried, and upon little more. But at the end of the inscription you have that piece of historical documentary evidence, "And he came to Pevensey" (it is written just above the last of the four foremost ships proceeding to disembarkation: the ship with the cross upon its mast). 'The size of the transport, the great number of the ships, has

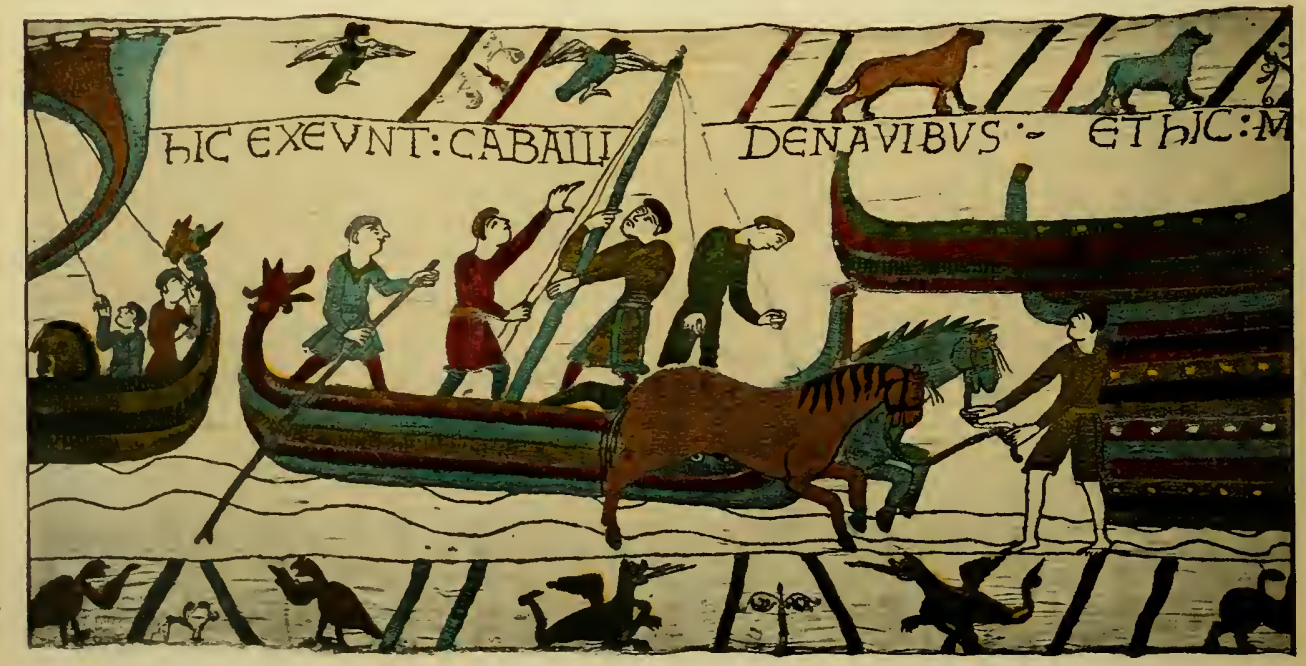




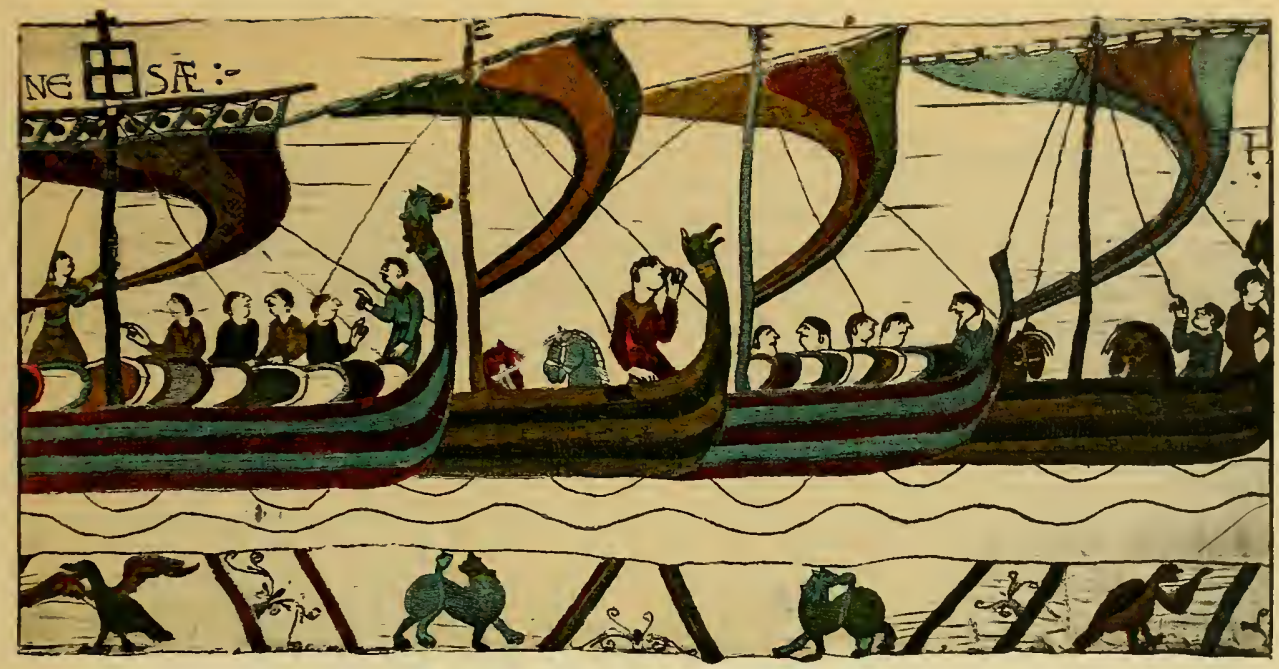

evidently impressed the artist, and he has tried to symbolise it. You get exactly the same thing in Wace: "I have heard it told to my father that there were 700 ships less four." Then, again, the word Pevensey comes into the Roman de Rou, though spelt "Penevesal " in that document.

In the next panel (47), which is the disembarkation, the horses are again insisted upon, and one curious point which I would remark, the un-stepping of the mast. There are not a few descriptions in the later Dark Ages and the early Middle Ages which lead us to believe that the mast of their small craft was not fixed: for instance, the Danes going up river above London Bridge. Let me repeat again, at the risk of tedium, that the episode of the disembarkation of horses, which the men of the time seem to have been particularly struck by, makes the Tapestry follow Wace. Once landed, the army in the next panel (48) fully accoutred-or rather patrols of it-rides out to forage,

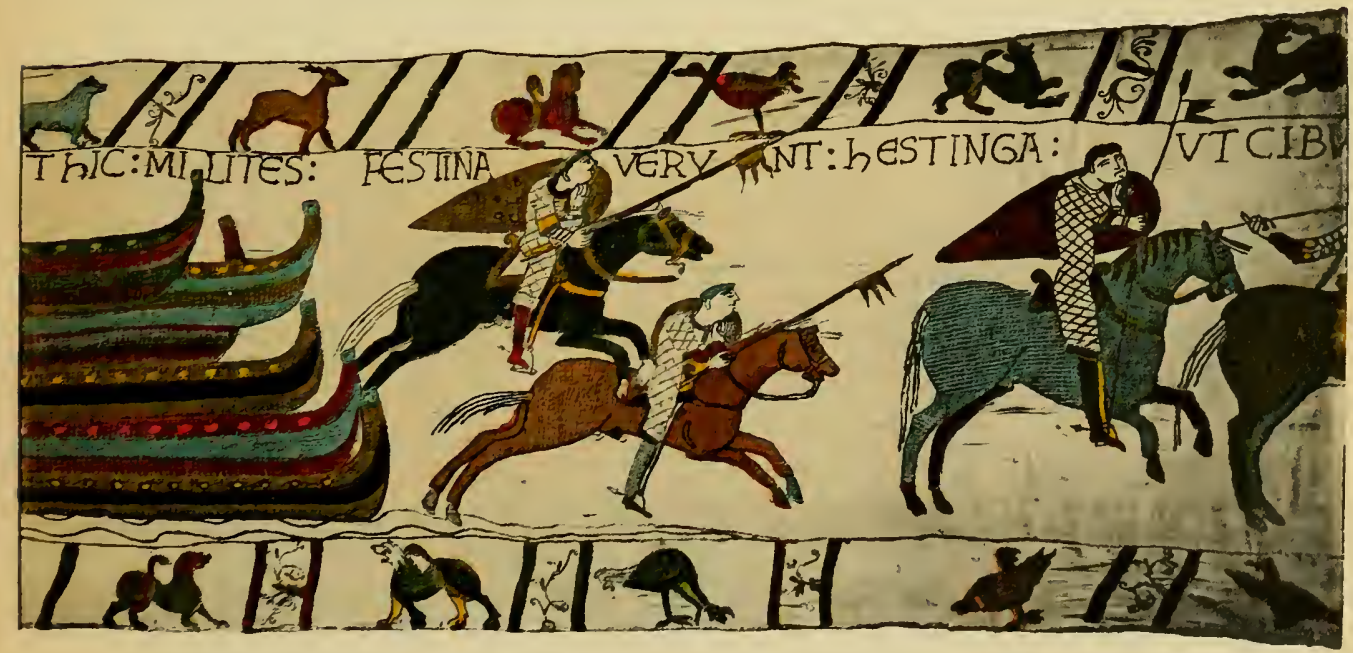




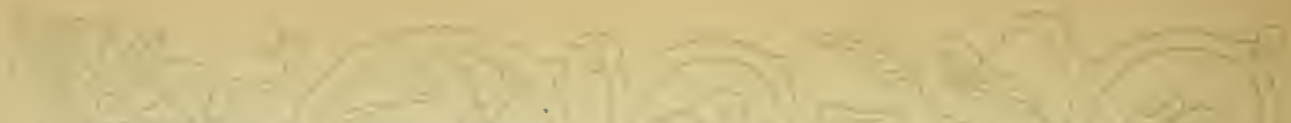

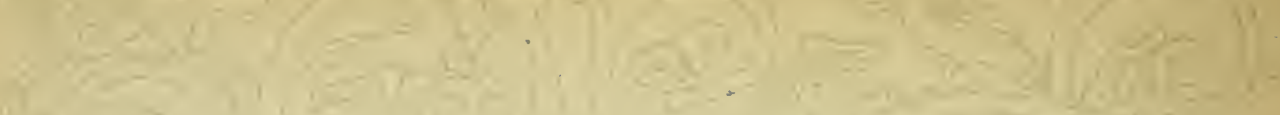

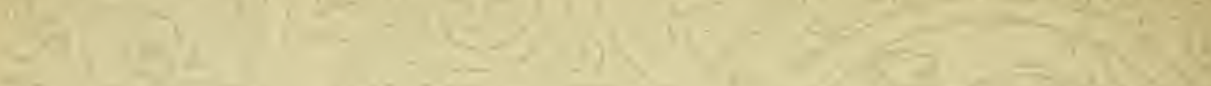

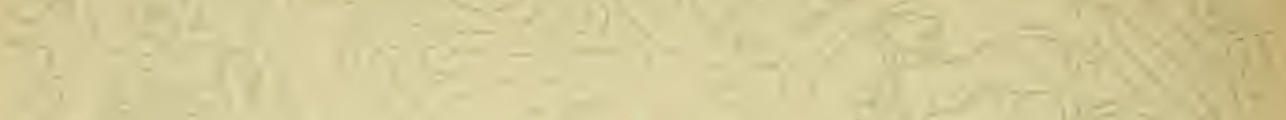

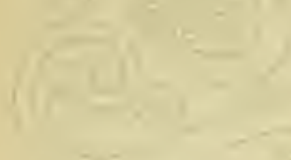

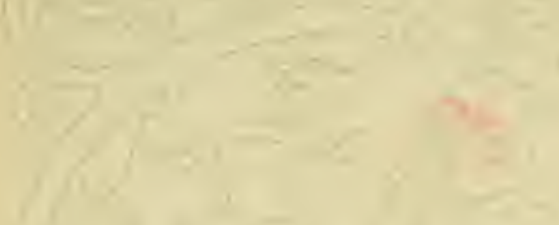
$1_{1}$

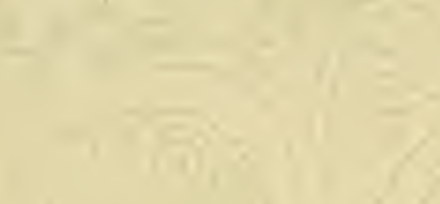$$
\text { 2. }
$$

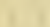

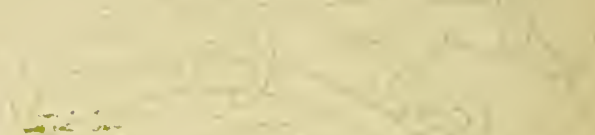

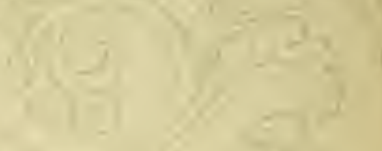

$-2+2+3-20$

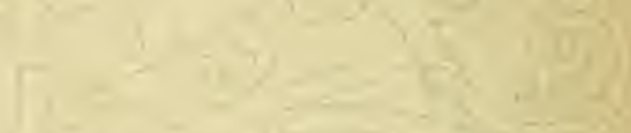

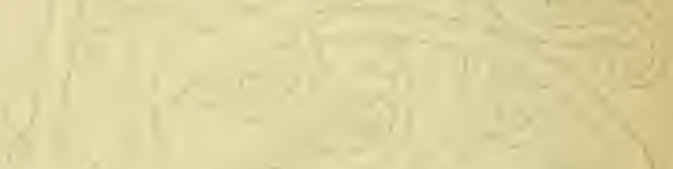

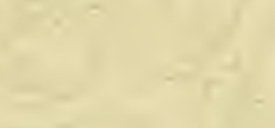

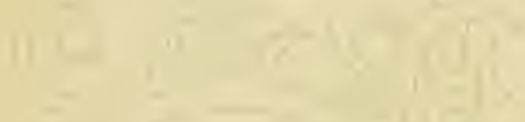

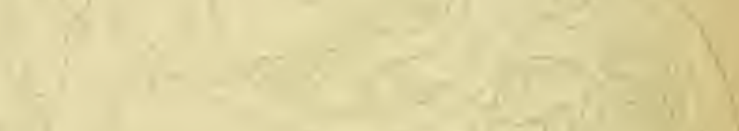

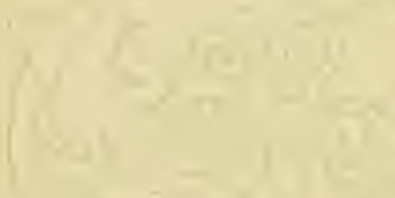

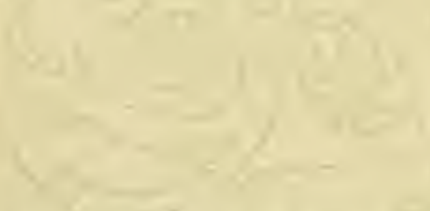

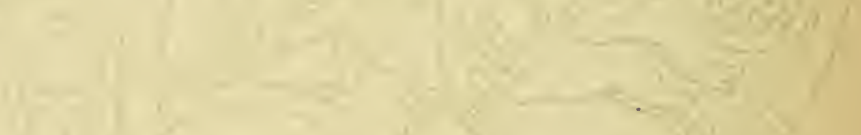

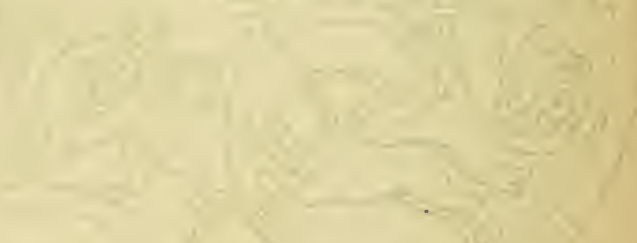

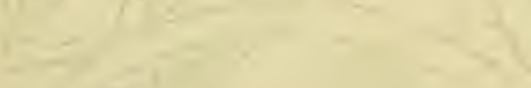

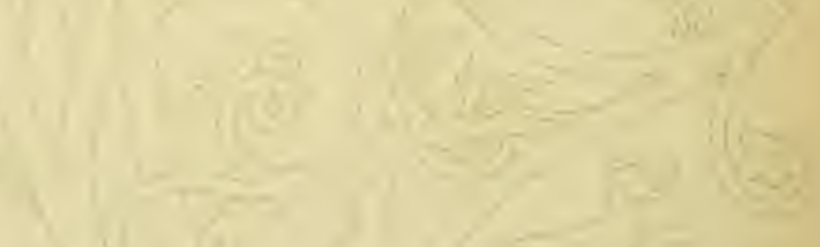

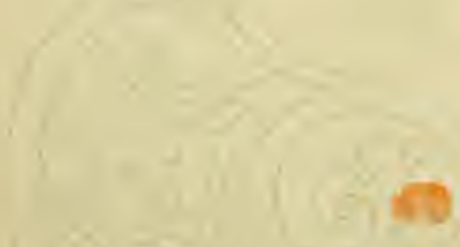

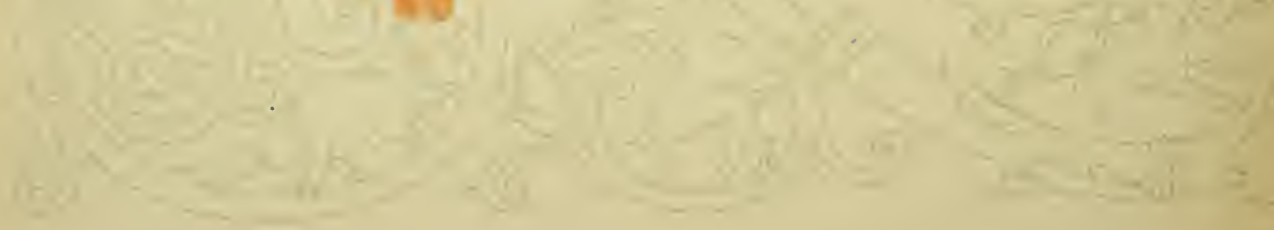




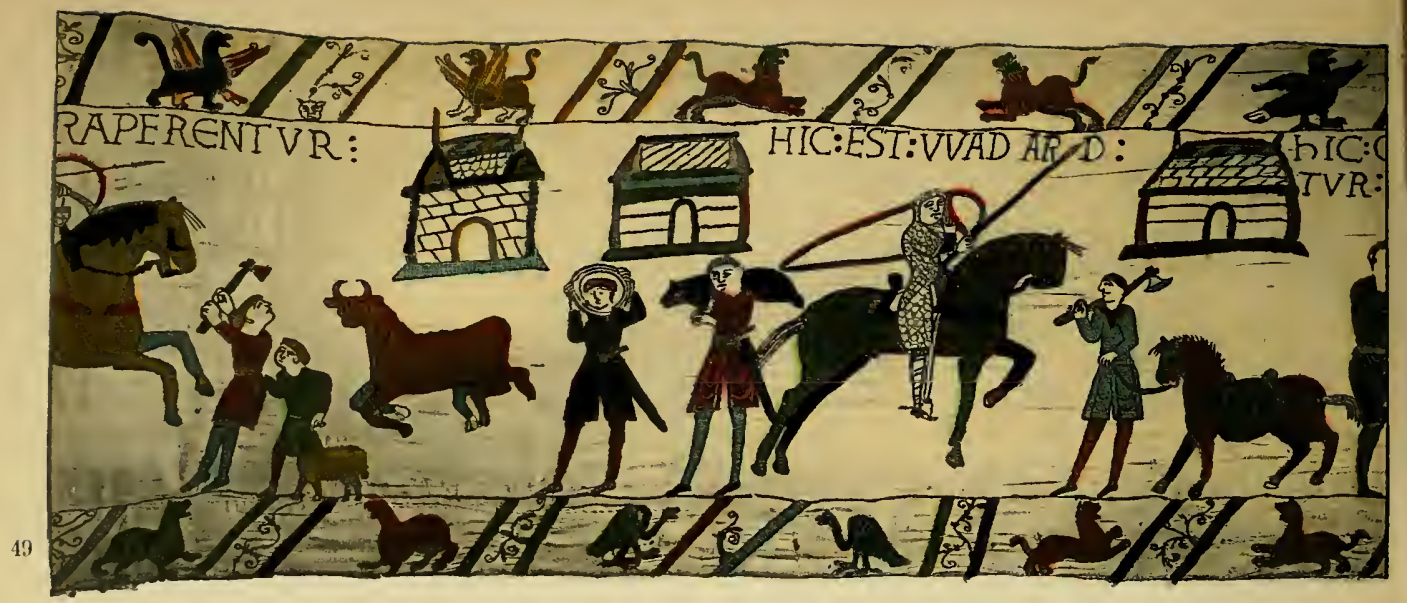

and you get as a sequel (in 49) the raiding of houses, the slaughtering of cattle and of sheep, the commandeering of horses; and next again (in 50) you have the preparing of a meal, and it is to be remarked how minute are the details here compared with the vagueness of detail in the building of the ships. Look, for instance, at the little stove of charcoal on which one of the cooks is preparing the meat, and the spits with their roasted pieces, and see how the draughtsman-whoever he was-knew more of courts than of artizans. And the feast itself, which follows, is interesting as showing a table laid out in continuity with classic custom, served from the inside of its horse-shoe or oblong. In the inscription, though hardly to be discerned upon the Tapestry, we have the benediction of the meats by the bishop-and the bishop should mean Odo. But we have, I believe, no MSS. authority for that littie incident at all. The bishop is probably brought in here for the purpose of the next

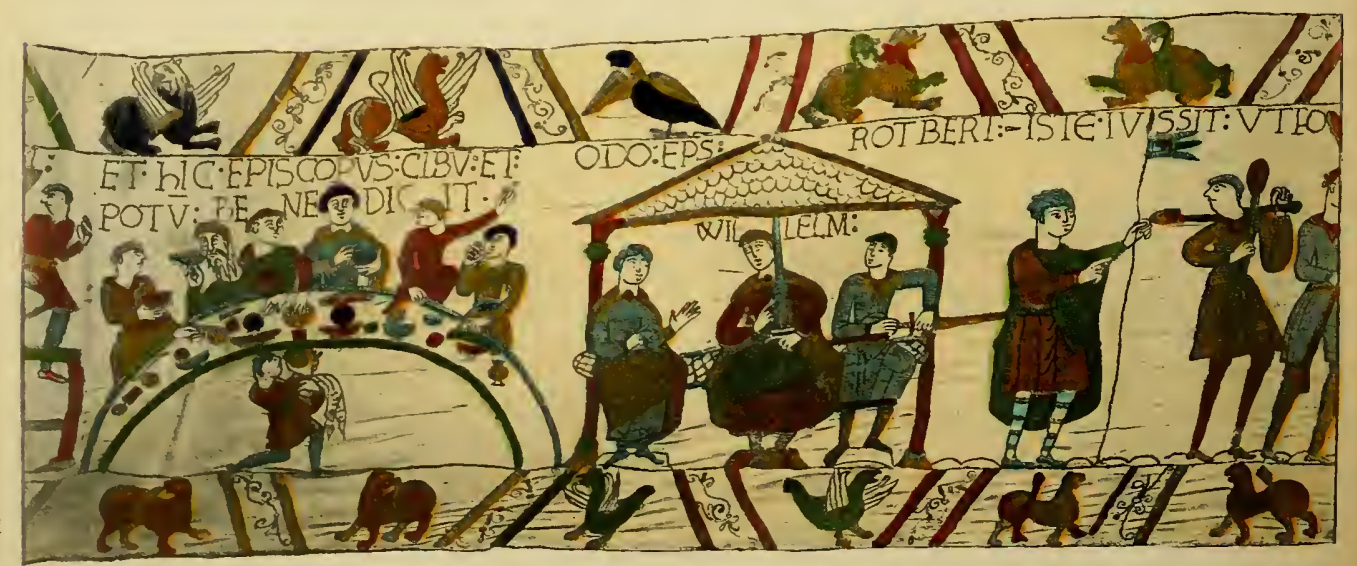




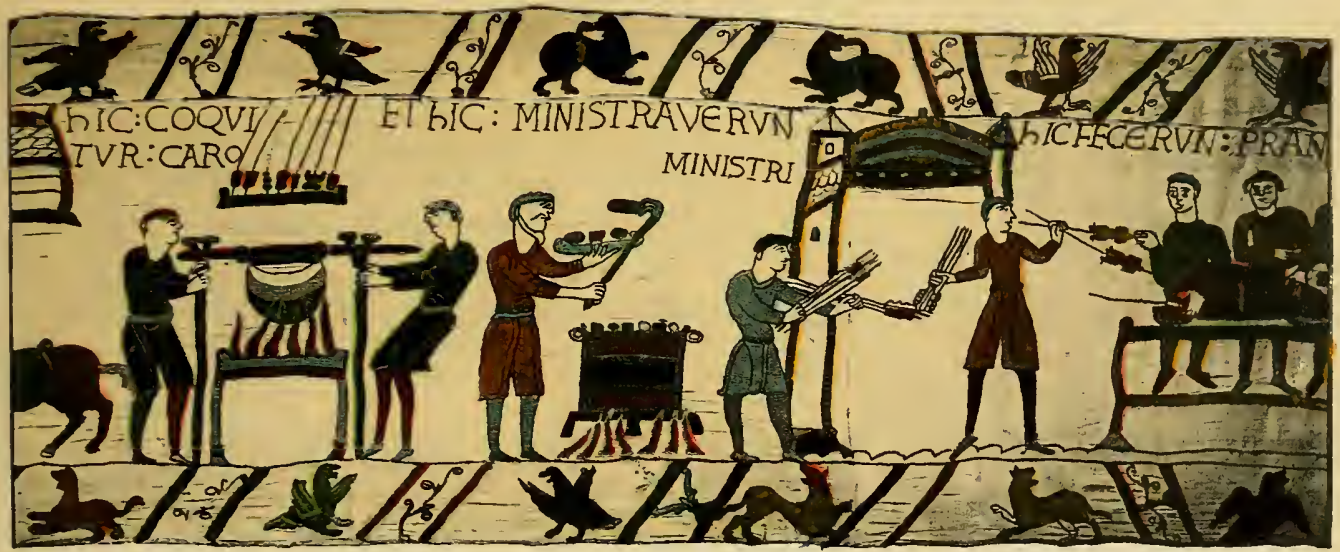

scene, where he sits with his brother, Duke William, and with his other brother, Robert, making council. The symbolism of the three figures is obvious; the portraiture of William reappears, the unarmed priest upon the left, the vassal brother upon the right making ready to draw the sword. In the next panel (52) there is given the throwing up of earthworks for a fortified camp at Hastings (the spade is half warfare), and here notice the figure of Robert of Eu, for it exactly follows the account of Wace. The figure holds the lance, and in command of the building of the camp is the man whom the Roman de Rou speaks of as commanding the same work.

With this panel the preliminaries of the action may be said to end, and the advance towards the battle itself to begin. There are two incidents in the next panel introducing that advance: one in which a messenger from Harold reaches William (whose portrait is again clearly marked), another in

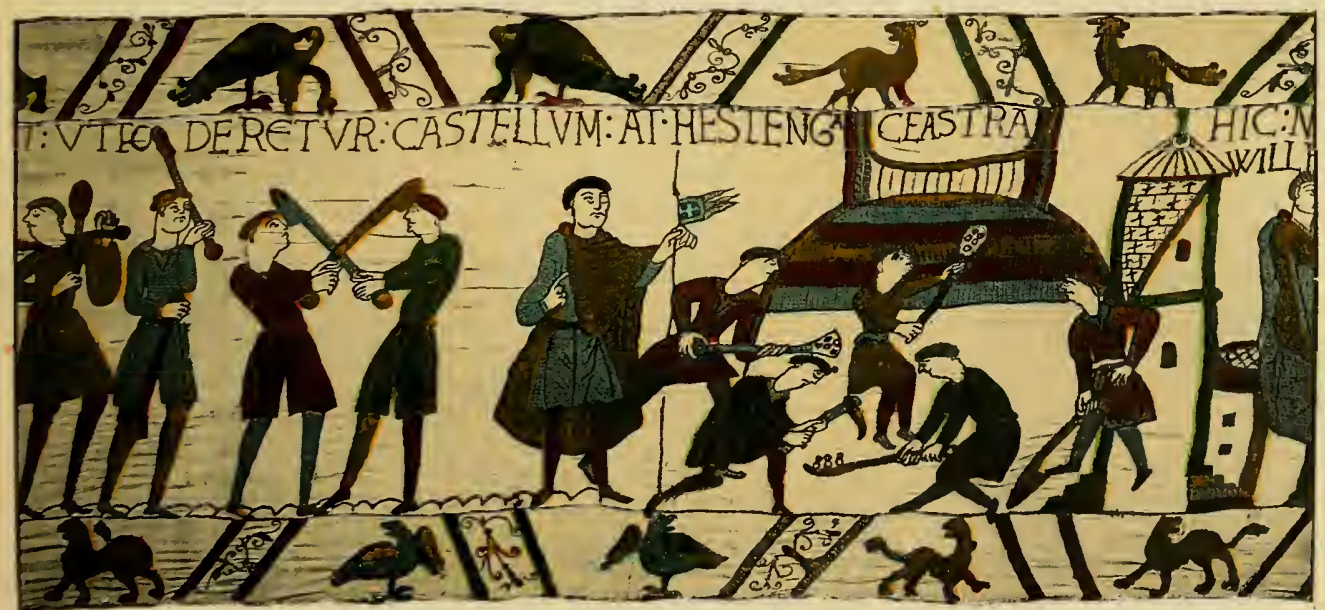






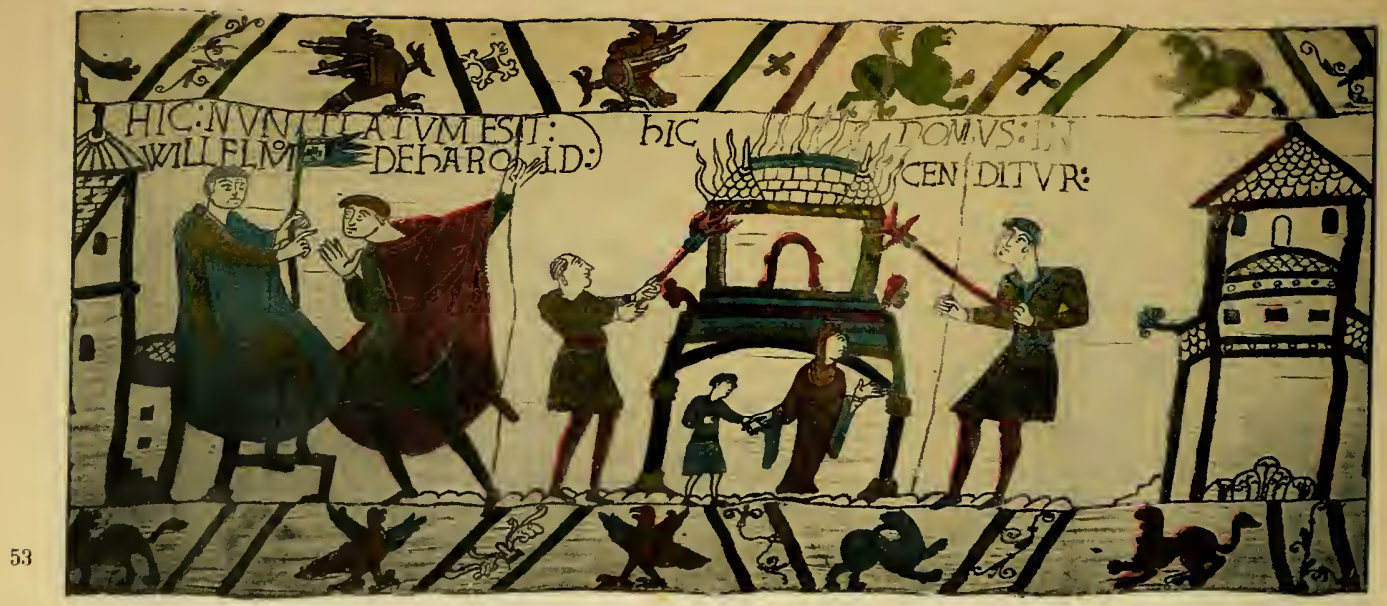

which the act of war begins with the burning of a house.

Wace gives us the story of a friendly baron, whose name he did not know, but who came and warned William of Harold's movements. As to the burning of the house, there has been a great deal of guesswork about it. I believe it means no more than a bit of conventional symbolism that the war has begun in earnest. To these two incidents in panel 53 succeed the feats of arms which take up the remaining part of the Tapestry, and which I will treat as a whole.

This last portion of the document consists in twenty-two panels, from the $54^{\text {th }}$ to the $75^{\text {th }}$ inclusive. In the first you have the conventional representation of a knight fully armed representing the whole body as it were, and riding out from Hastings on the morning of that October day which by sunset had determined the fate of England.

It has been said by more than one modern English writer that the soldier

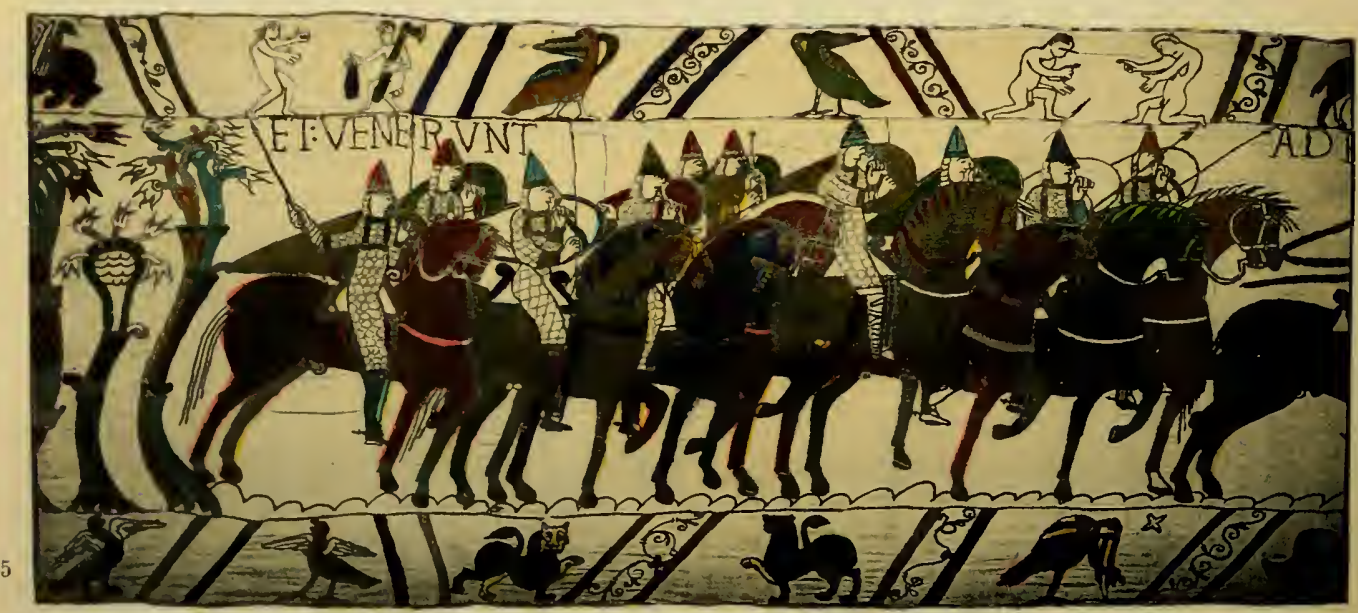




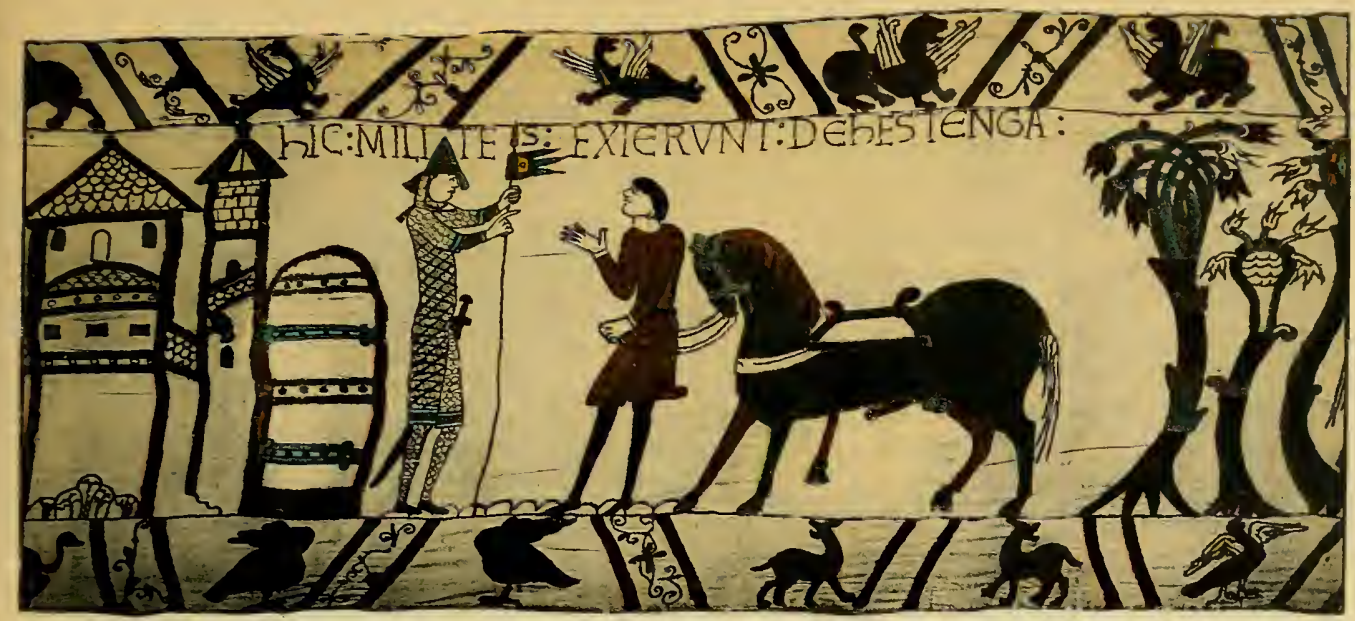

thus pictured is William himself, and consequently that the horse is that Spanish horse which Alphonso had given William, and that its leader is William's old liegeman, Walter Giffard, who had brought it back with him from Spain.

Now this-like such masses of Freeman! - is not only conjecture, it is also false conjecture. Wherever William appears he is called William, and it is unthinkable under the conditions of the time that his figure should be given under the general name "knights." Nor is the conventional figure leading forward the stallion an old man; he is, if anything, on the young side.

I will not here repeat what I have said elsewhere with regard to the accoutrement of the knight, though it bears out in this particular panel very strongly the conclusions of the Introduction as to the age of the document.

The next two panels ( 55 and $5^{6}$ ) are very interesting because they show by what conventions the artist expresses the act of deployment. As long as

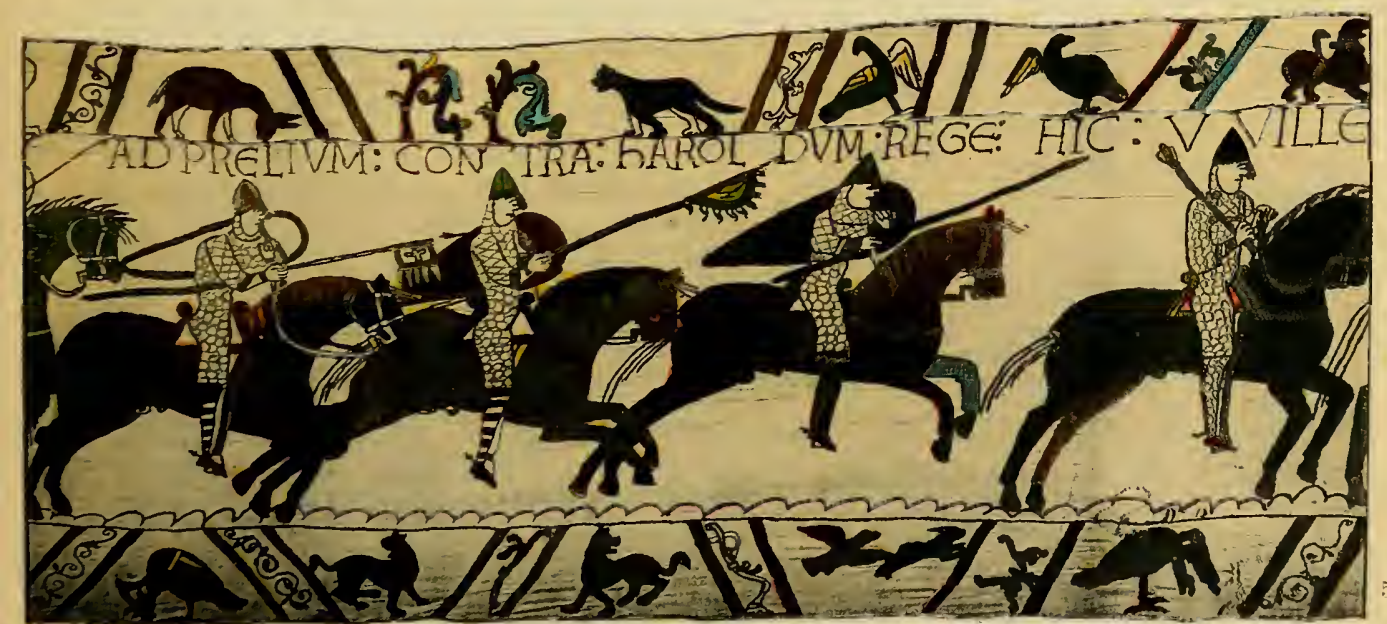





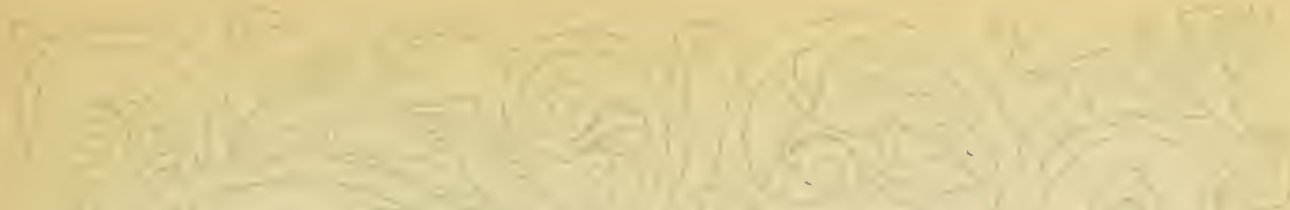

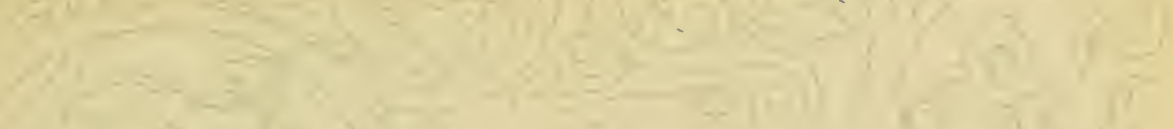

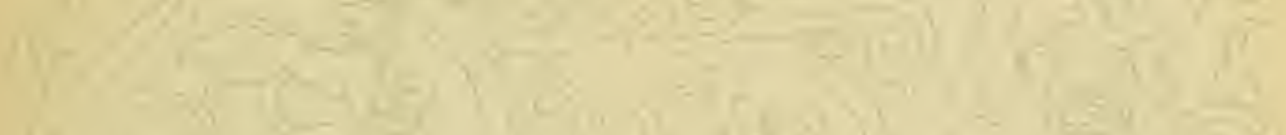

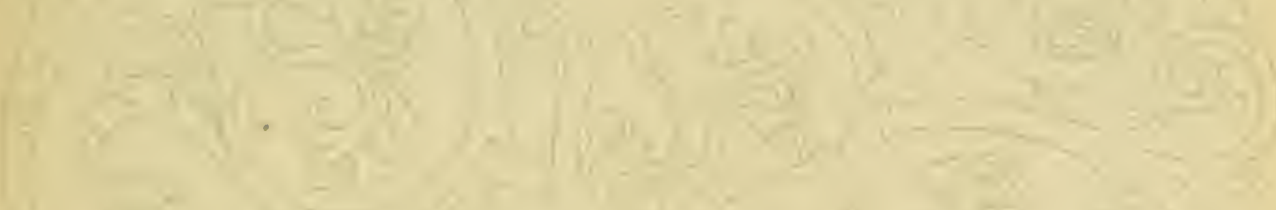

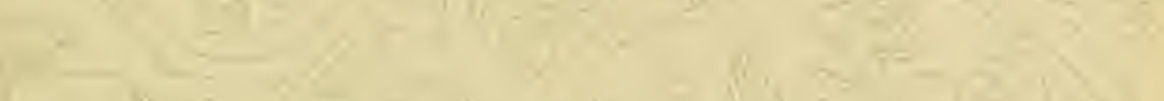
(8)

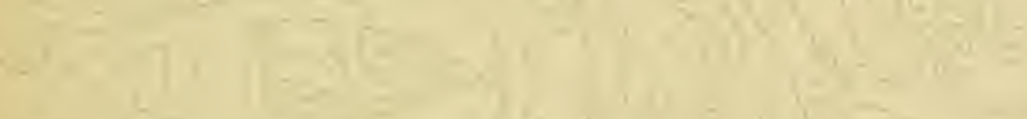

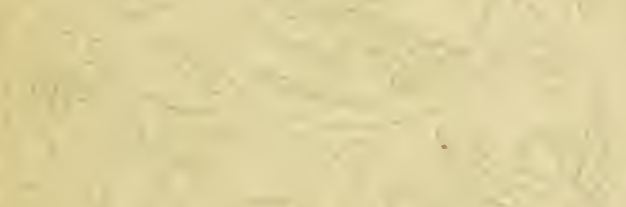

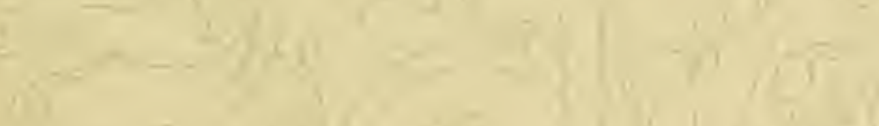

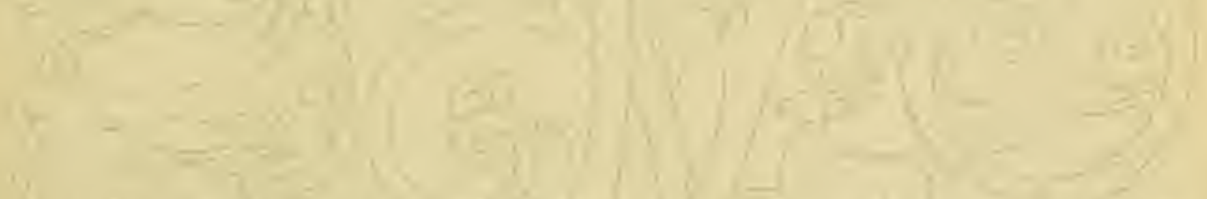

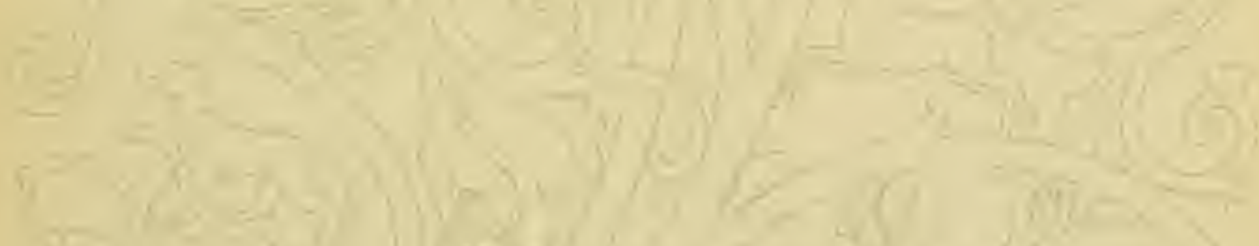

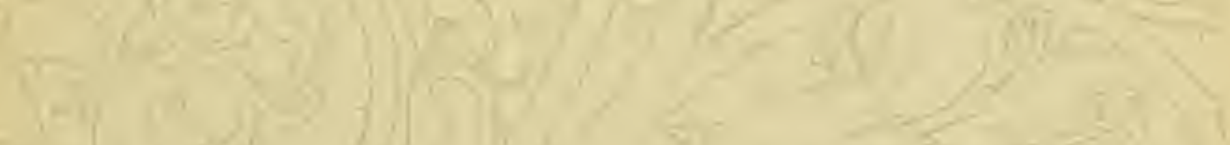

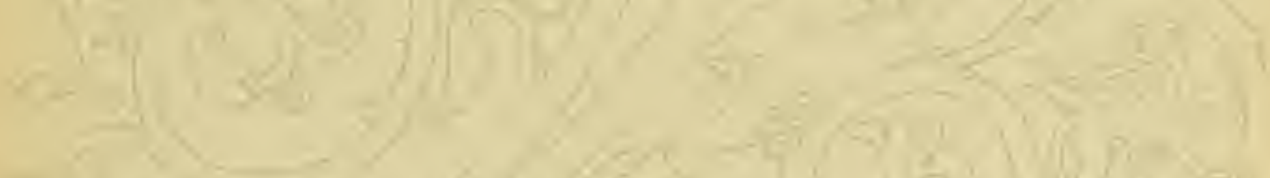

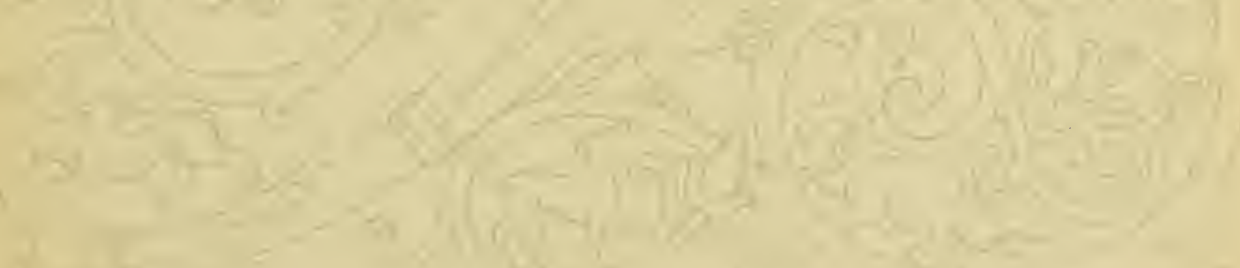
I 


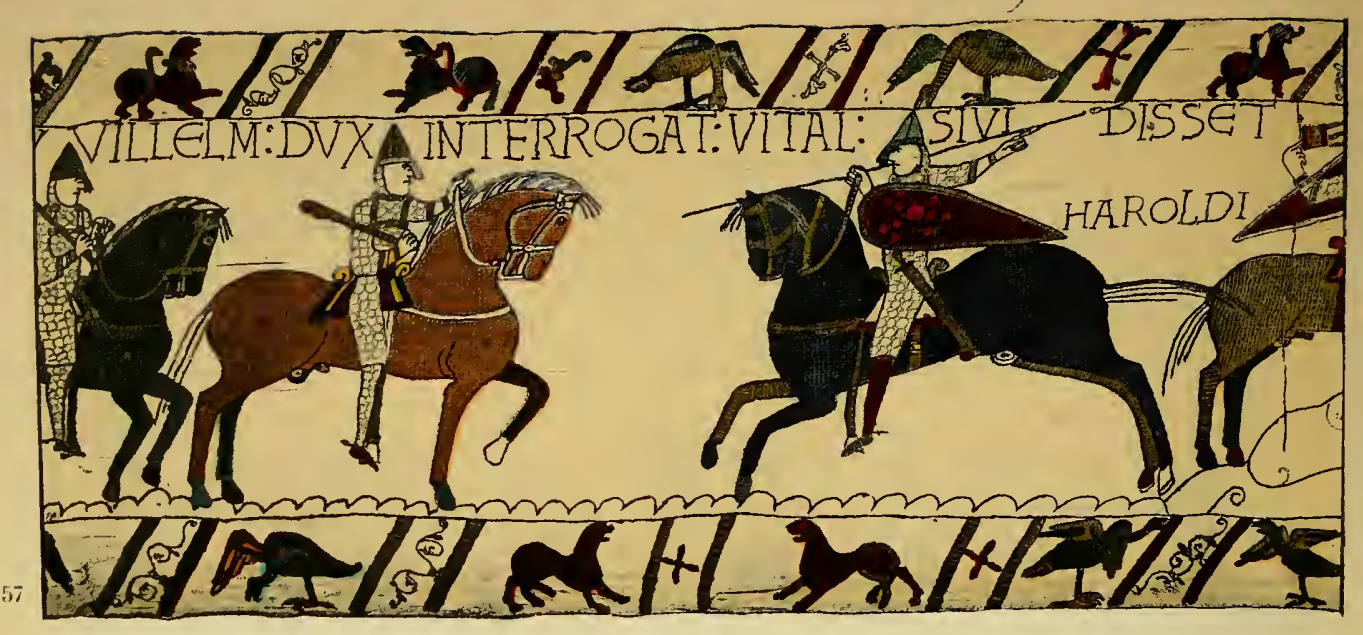

the cavalry are marching in column of route he puts each figure only slightly overlapping the next, and suggests a walking space for the mounts; to express deployment or formation into a broad column of attack, as he has not the mastery of perspective, he puts the horses at the gallop and separates them much further one from the other.

The next point of interest in these panels is the personality of William bearing not a sword or lance, but a staff of authority or mace; while behind him is a figure bearing a sceptre, and it is only behind him again that you have anything resembling the consecrated banner of the chroniclers. Here there is a conflict between the Tapestry and Wace, as well as a divergence between them, which shows (like the episode of the Breton War) that though our document is largely based upon Wace, it must also have other sources. For in the poem the consecrated banner is sent on before the host by William, and that indeed is what one would expect; while the interrogation of one Vital by

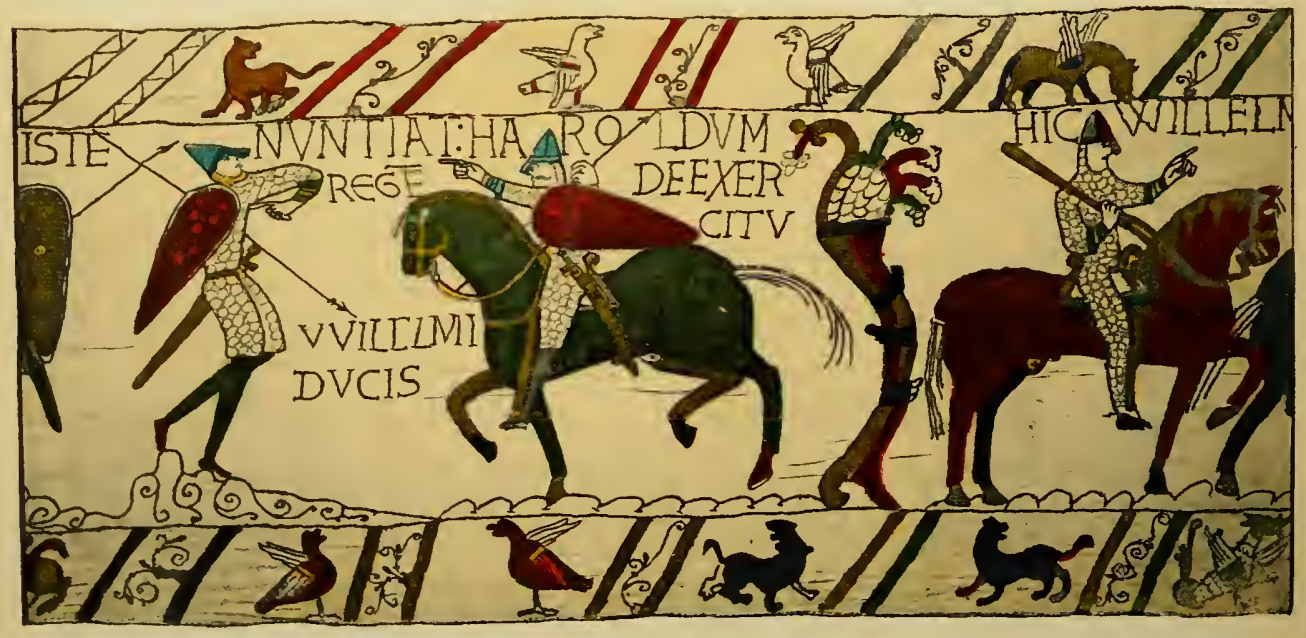




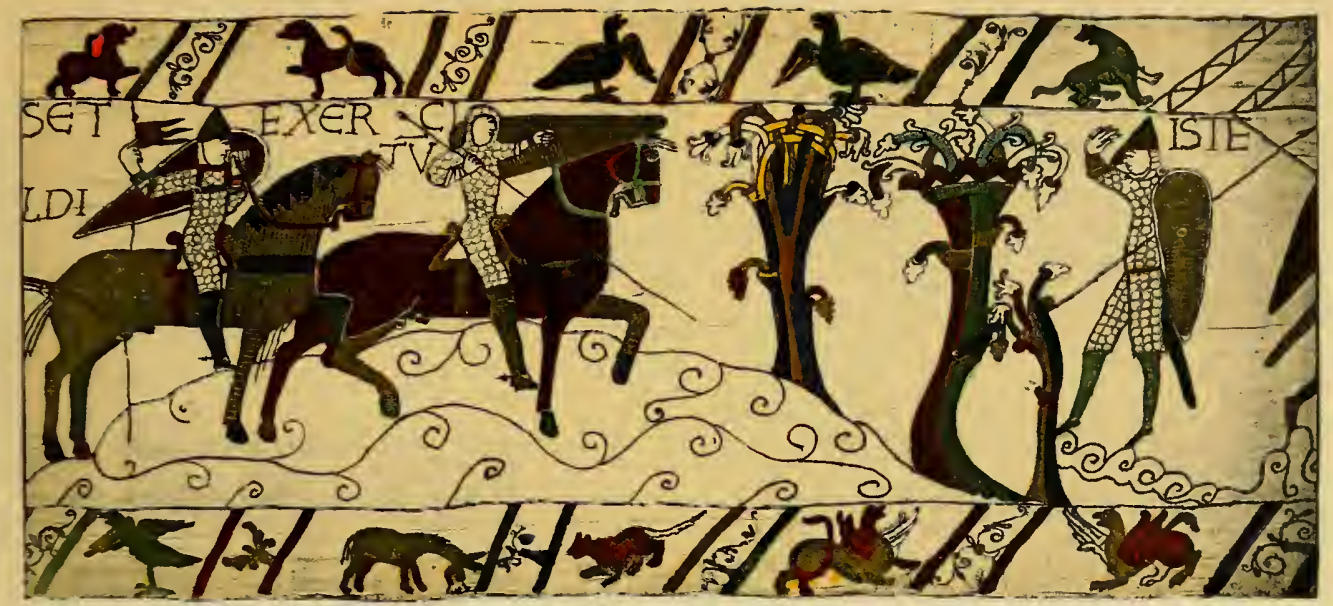

William as to the results of his scouting, though it seems to have been an incident that struck some contemporary or other vividly, is not found in any of the chronicles. Who Vital was there is no sort of evidence to tell us. It was a name known in Normandy. It occurs on a charter of William's brother in the list of witnesses, and again in Doomsday under the same lord. This Vital of the Tapestry points in the direction of the scouts (who appear as conventional figures in the 58 th panel), and there is here a little piece of realism which is of great interest to those who have studied the field. It will be observed that these scouts are represented as standing upon the summit and the hither slopes of a hill while on the farther slope you have trees conventionally represented. This hill, from which the scouts caught sight of Harold's army (which had marched up the day before and taken position after that splendid advance from London-one of the most rapid in history) was the hill now known as Telham Hill. The ridge on which Telham farm

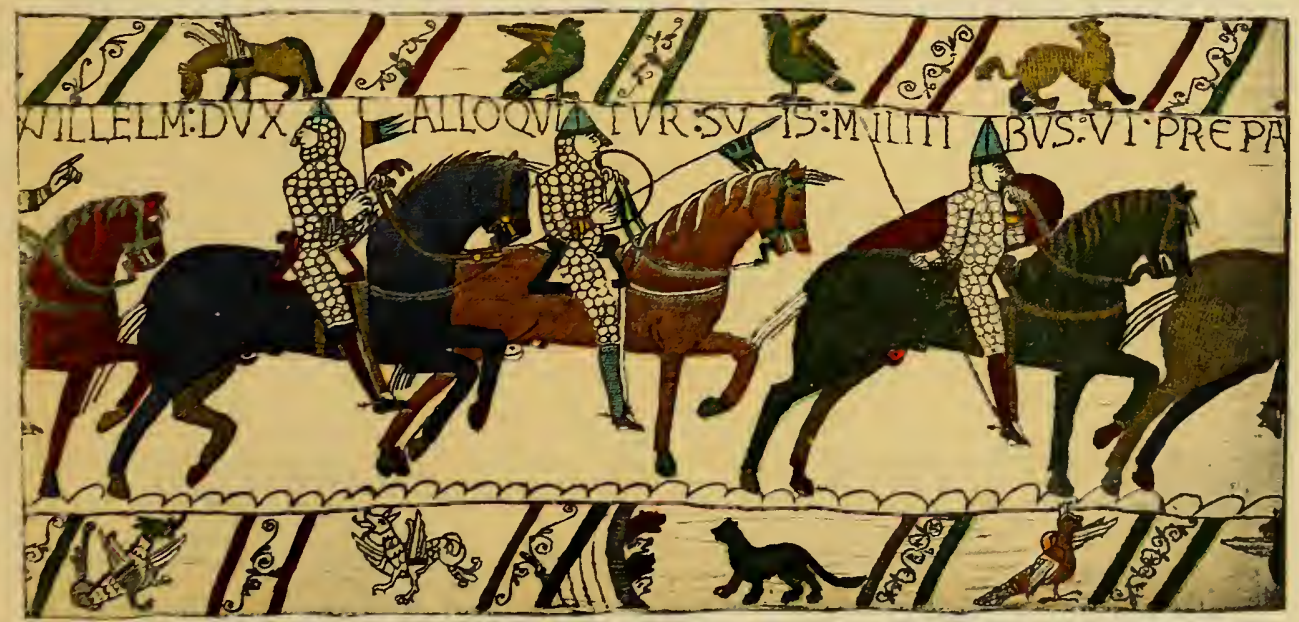


14.

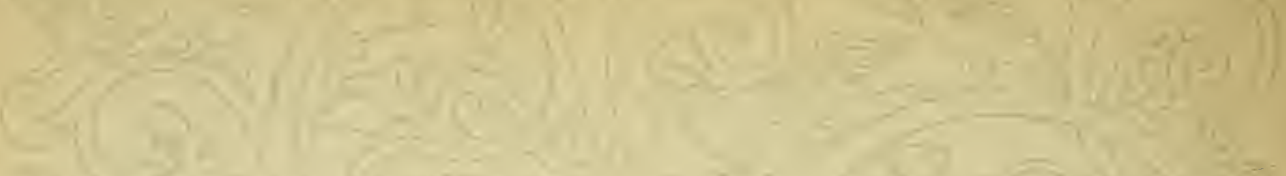

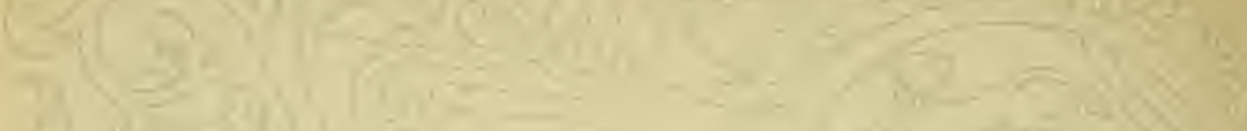

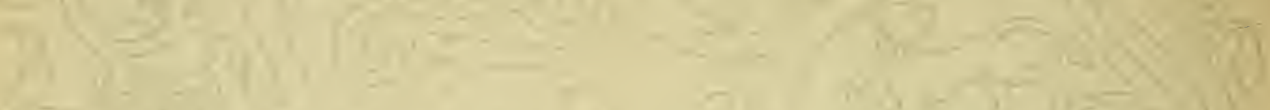

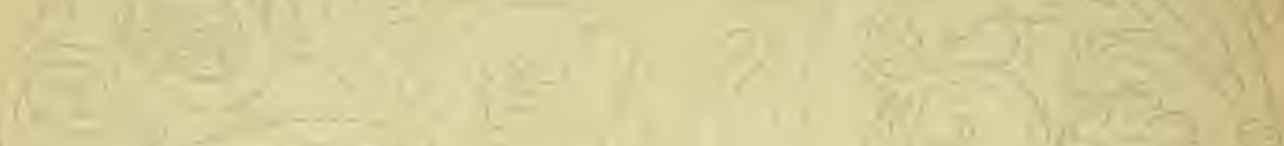

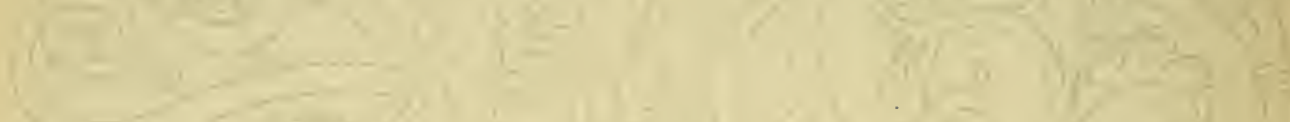

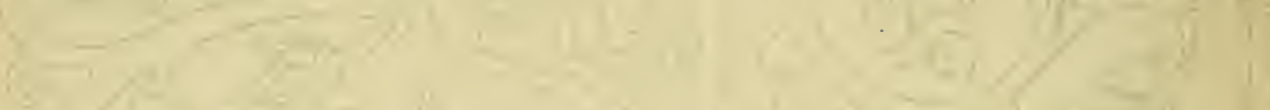

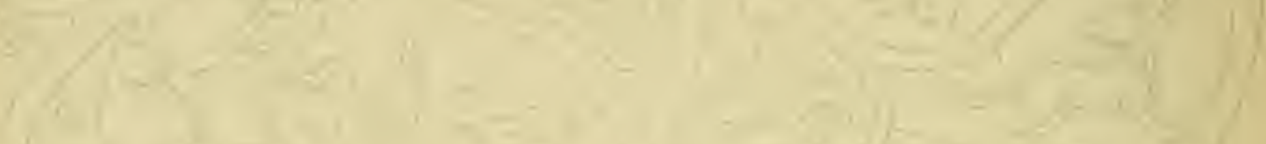

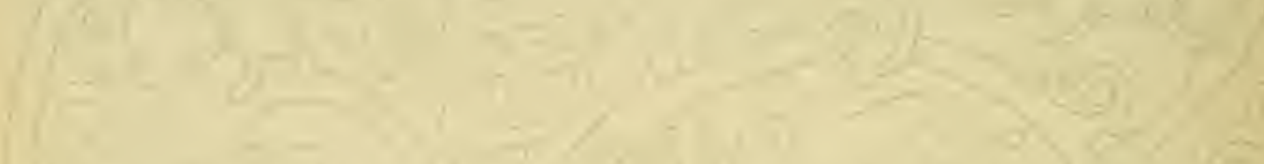

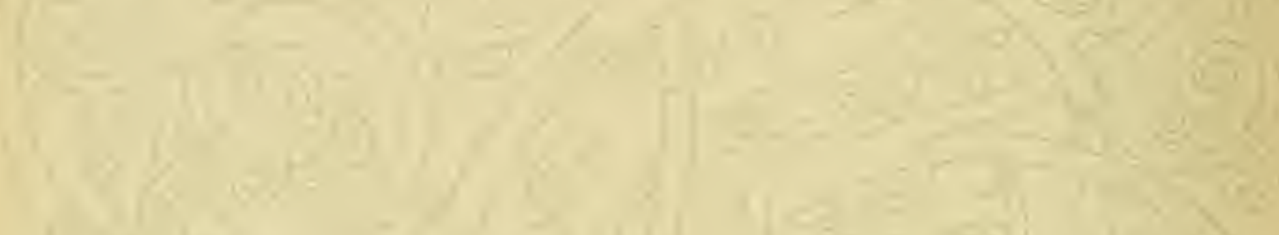

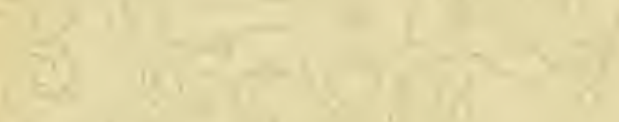

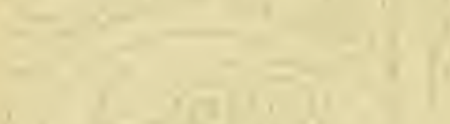

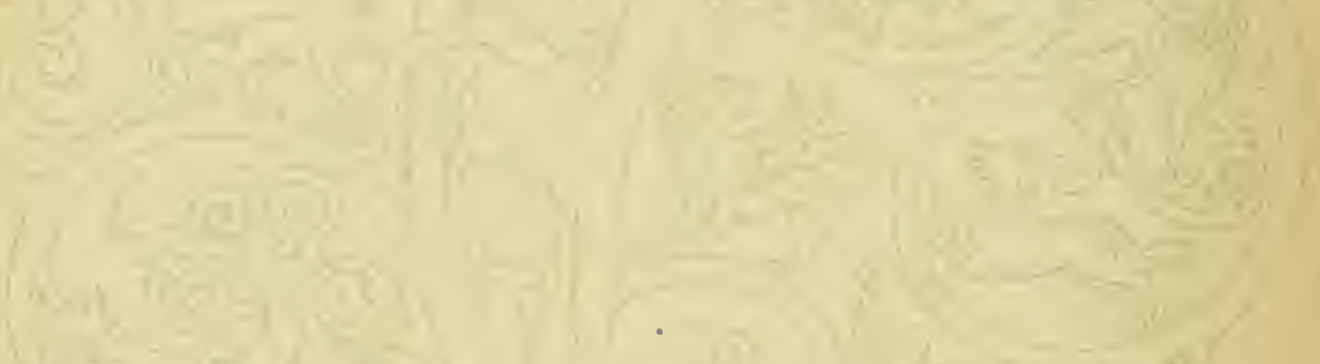

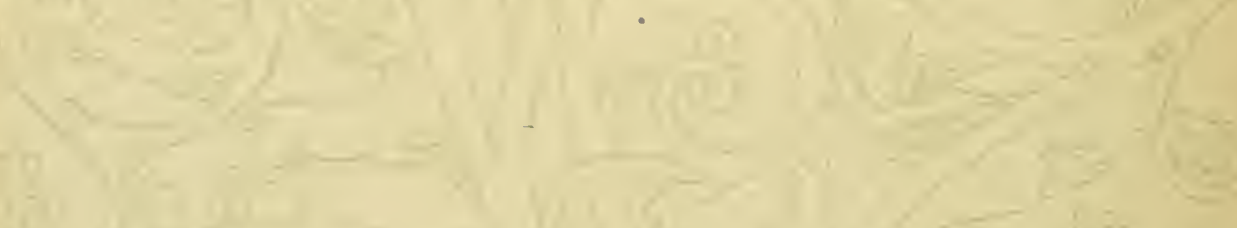

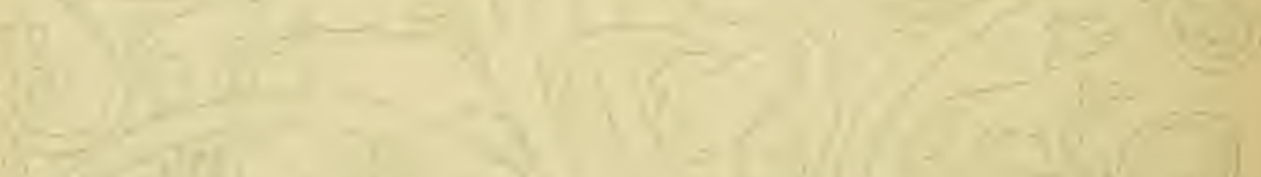

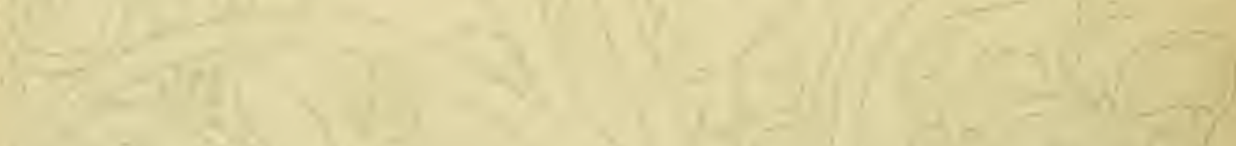
(1) 9.

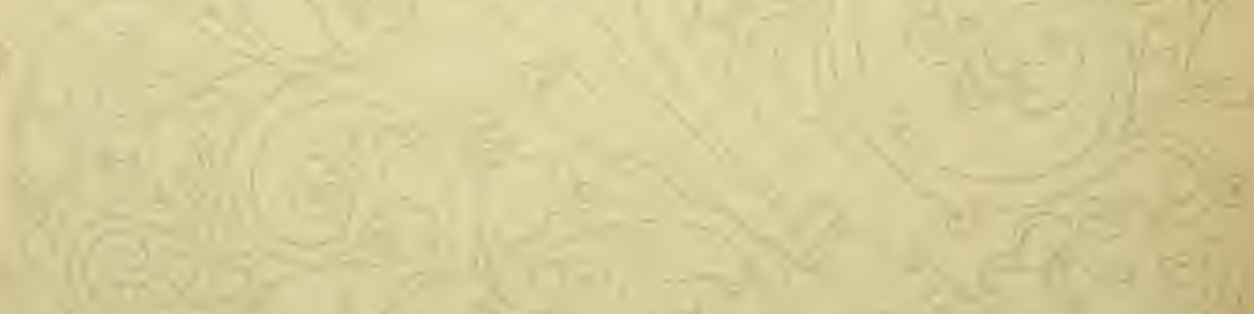

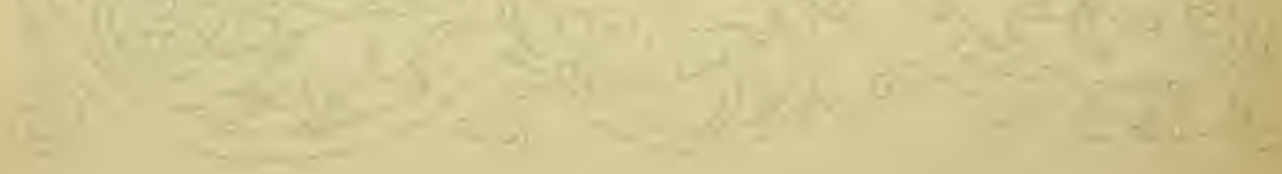




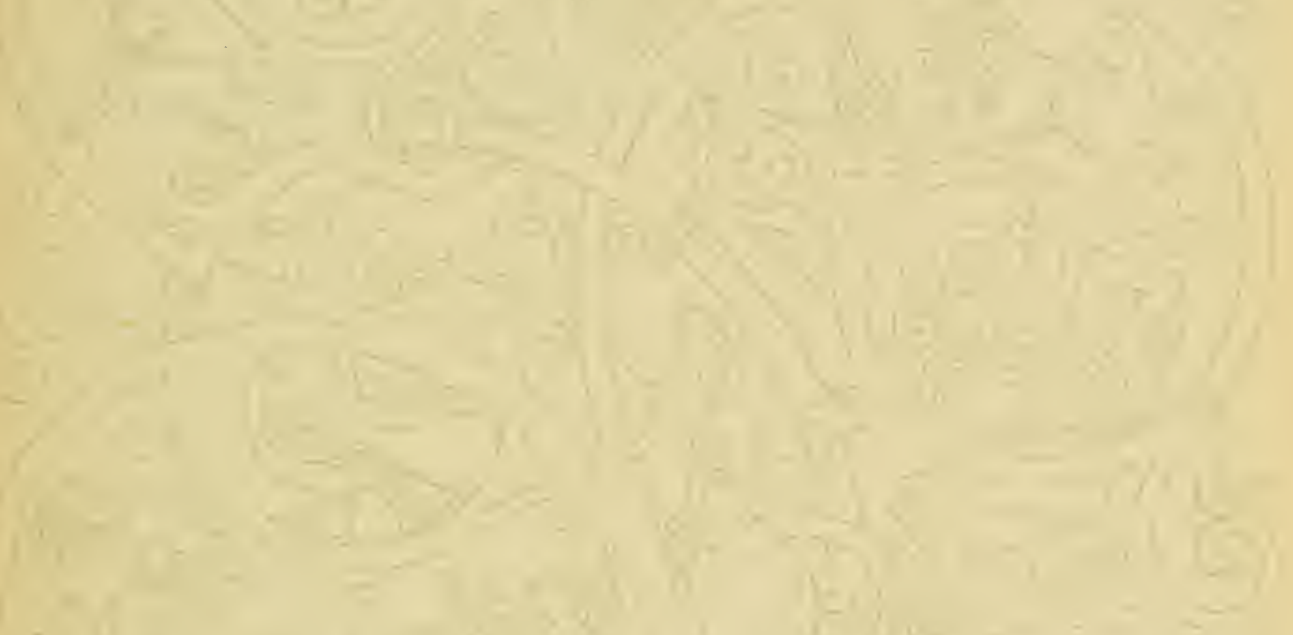<smiles>CCCC1CCCC1</smiles>

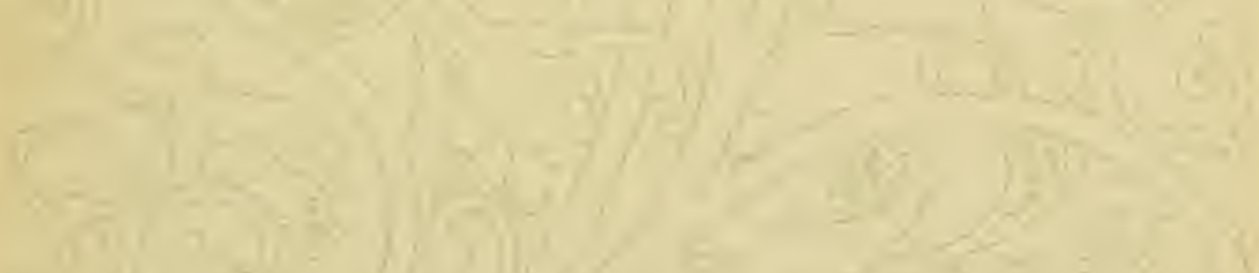

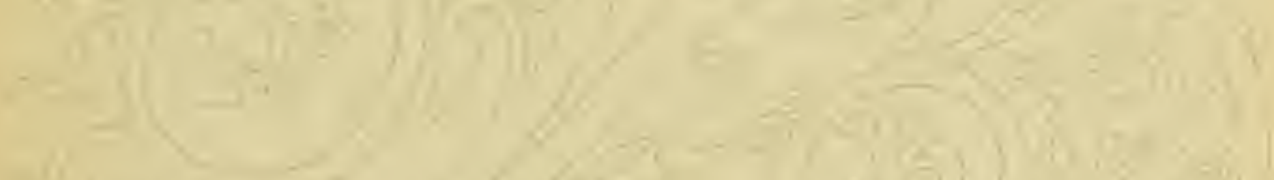

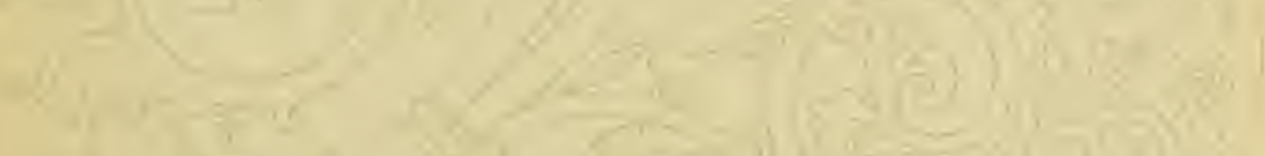

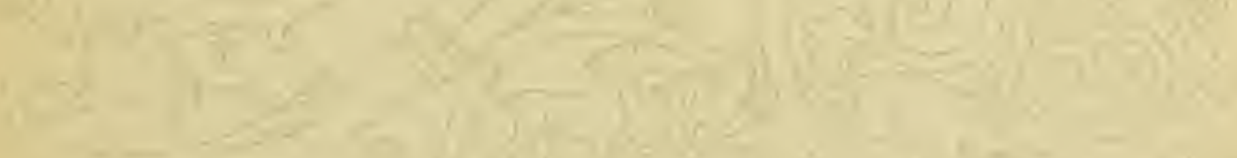

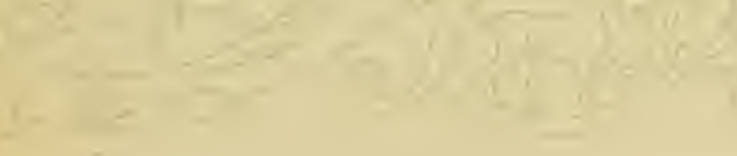




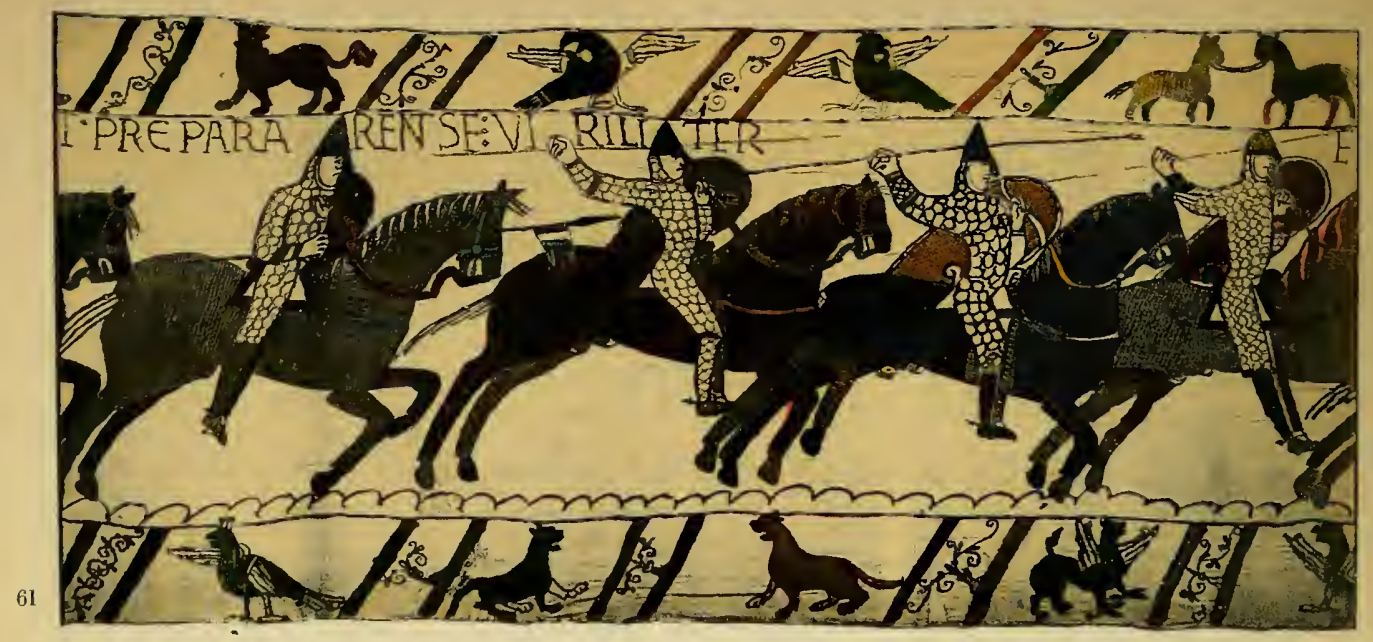

stands was the summit beyond which the scouts did not advance, and the wood on the slope immediately below is the wood represented in this panel. In the next panel (59), as the inscription tells us, the converse is going on in Harold's case, and his scouts (represented as being on foot) come to tell Harold, who is mounted, that they have established contact with the enemy. The 6oth panel stands for the speech William made to his troops before the battle. Most of the chronicles mention this episode, and Wace in particular. You get again, in the next panel, the deployment suggested as before, and then a group of four panels $(62-65$ inclusive) bearing no inscription (the words above them being no more than the continuation of the legend above William's speech: "That they should prepare themselves for battle against the English army both courageously and with art"). And these four panels are the effort of the artist, with such means as he had at his disposal, to give some conception of the order of battle.

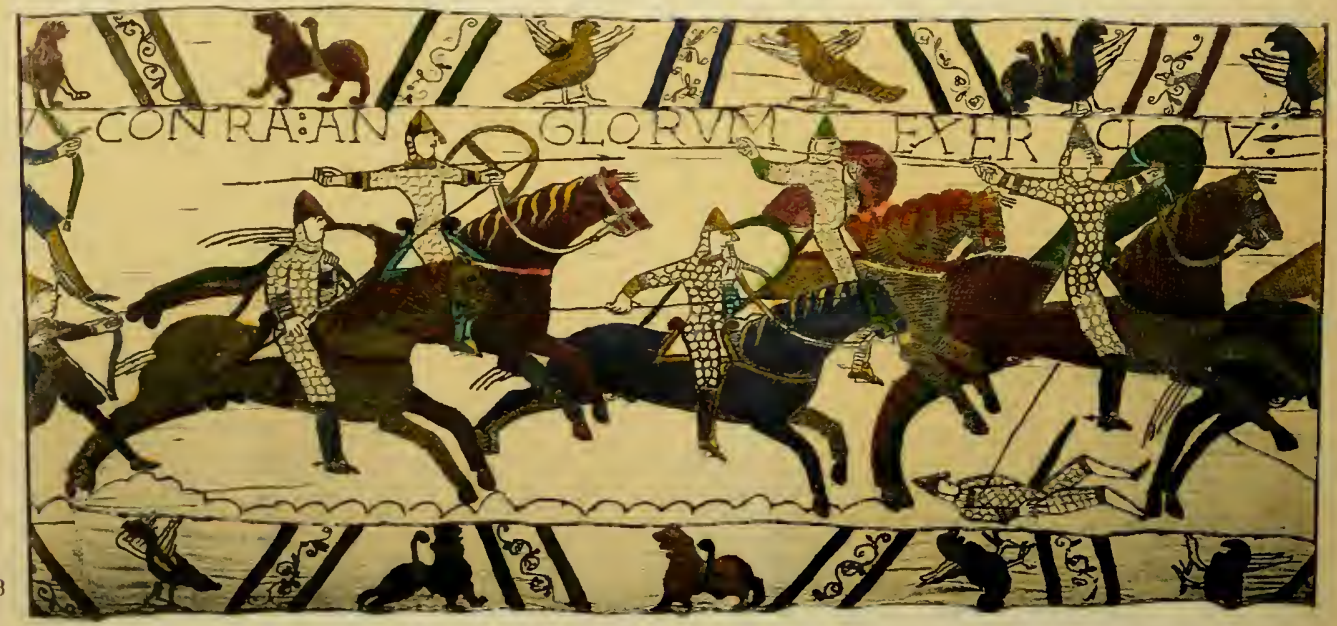




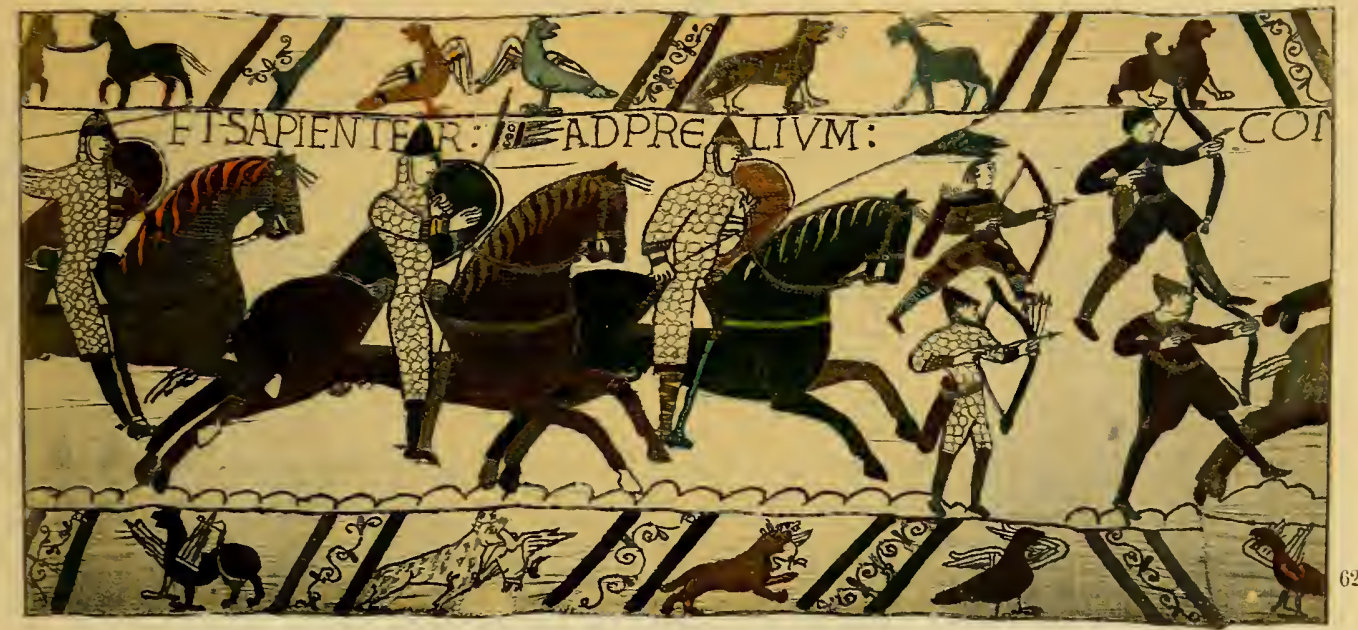

Now we know what that order was. There were three columns of attack, consisting of the fully armed and mounted knights. That on the left was composed of the Bretons in the main, and had the duty of charging over the space now occupied by, or neighbouring to, the pond in Battle Abbey park. That on the left, which was to charge the steepest part of the hill, was to cross the ground on which the station has been built in modern times; it was a column mainly French and led by Roger of Montmorency. The central column, which was to take the sharp hill between the two others, was composed mainly of Normans and was led by William himself. Upon the jutting promontory of the height which these three columns were to attack, stood the Saxons on foot, depending largely upon the axe as a defensive weapon, but also upon the throwing-spear or javelin, and to some extent upon the sword. In front of the attacking army was scattered in open order a line of archers, whose function was the permanent service of

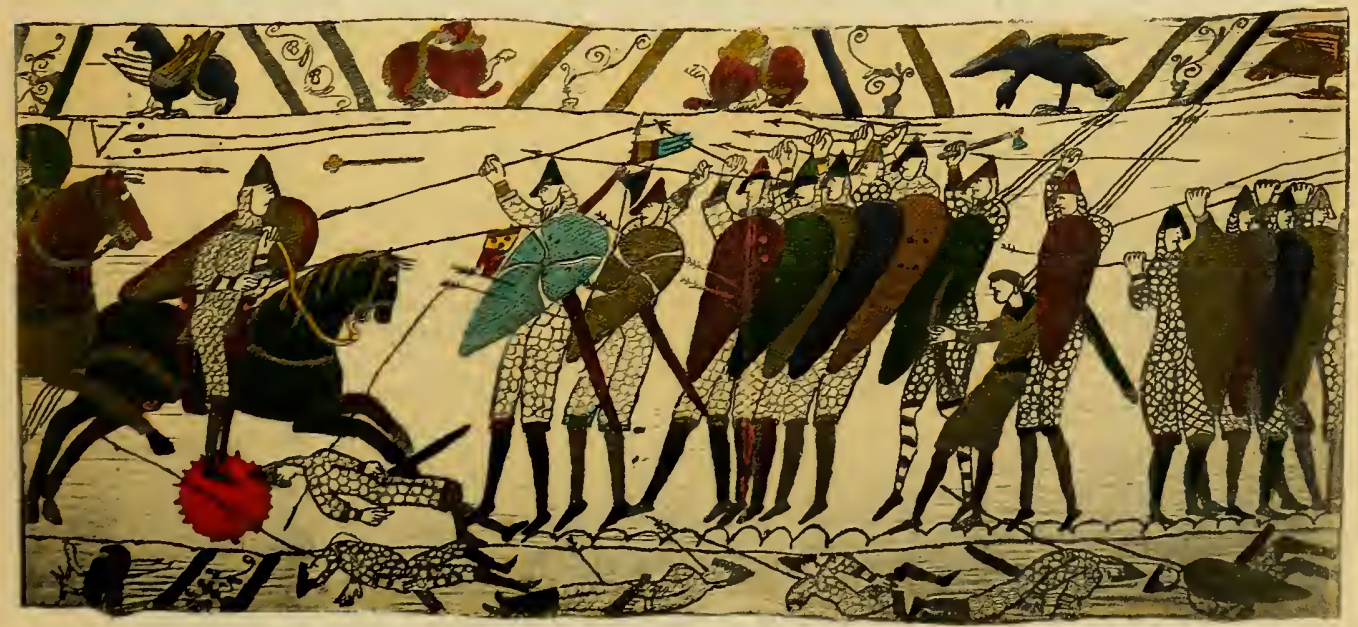




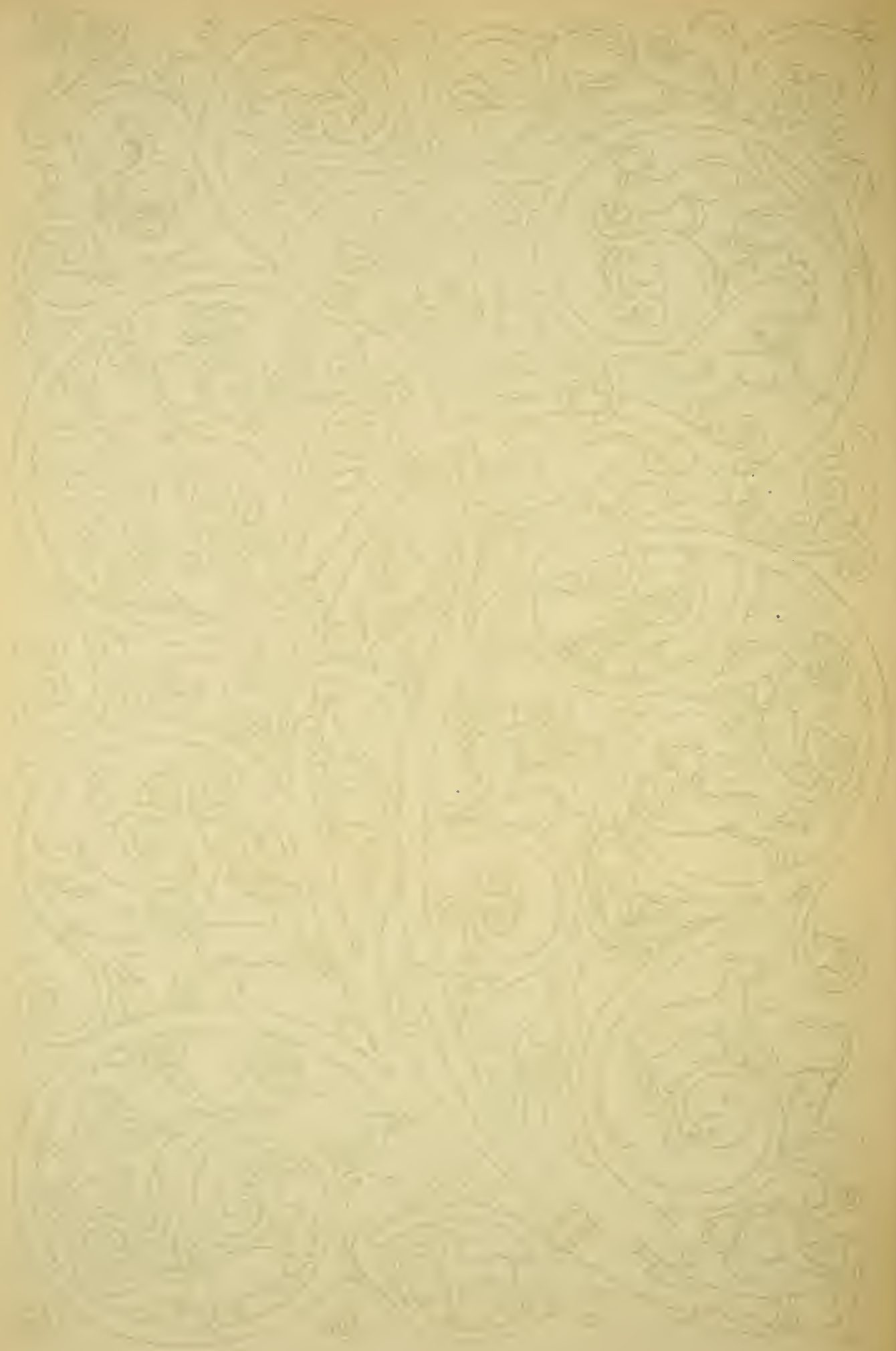




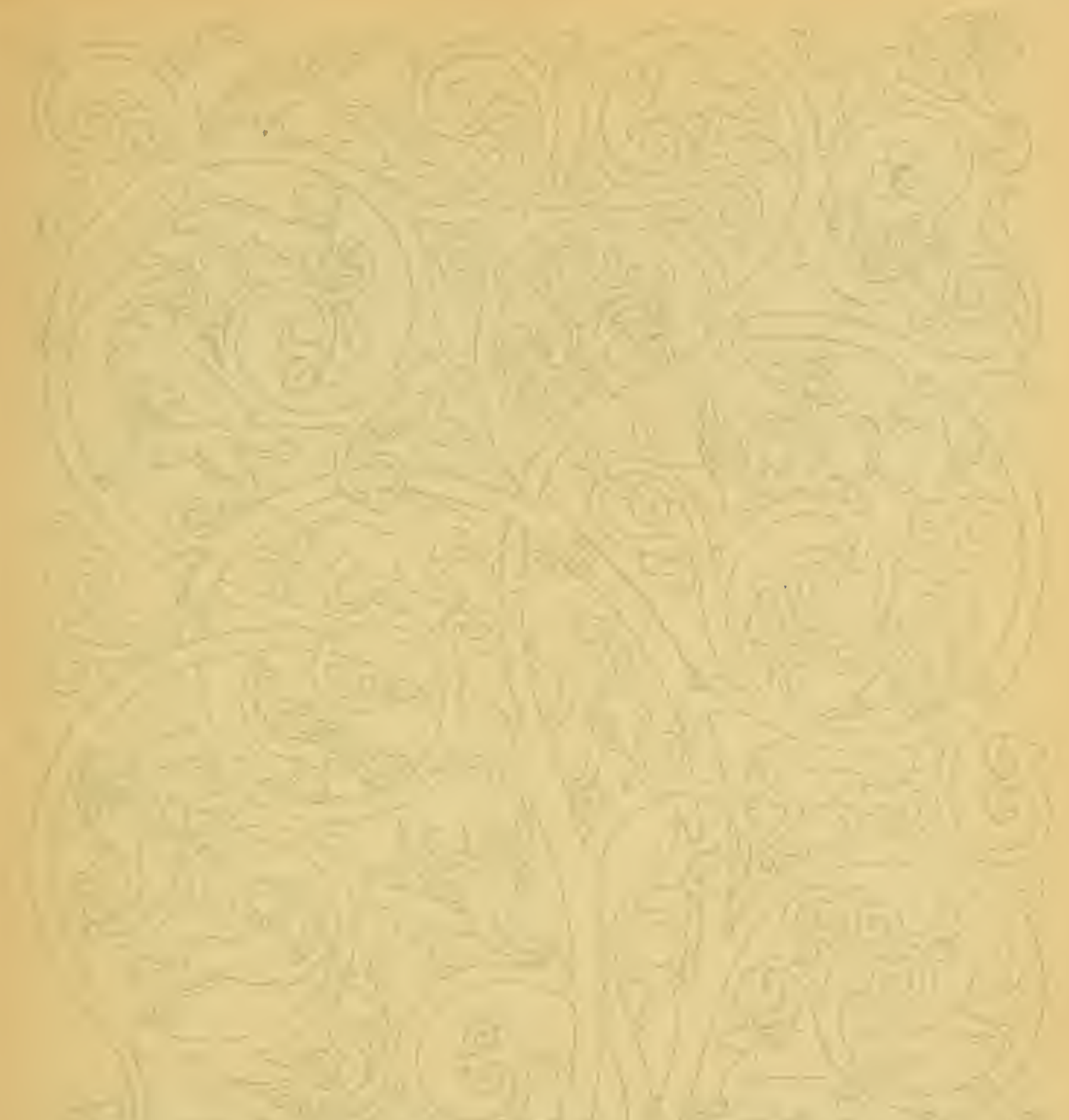

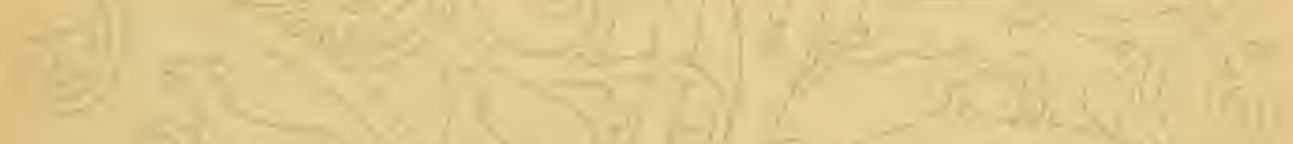

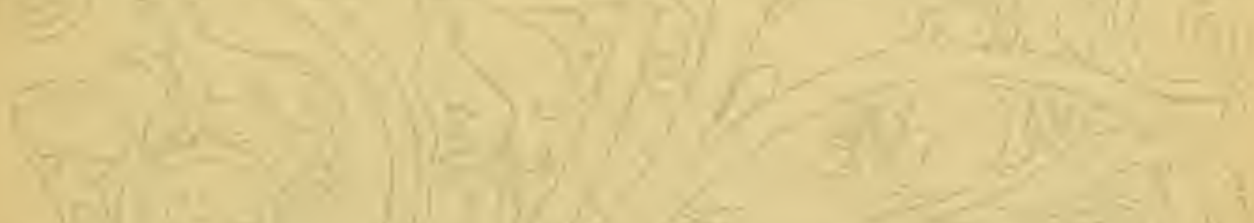
$2(x-5)=2)=0$

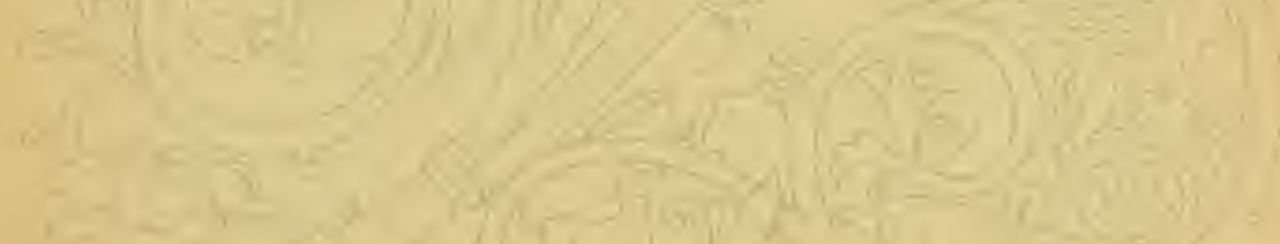

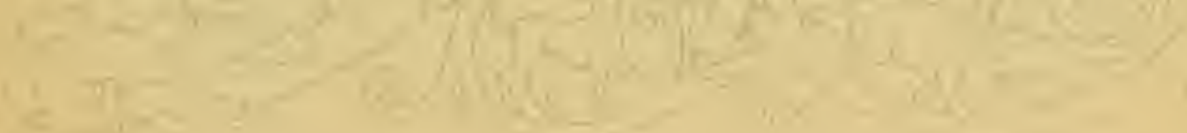




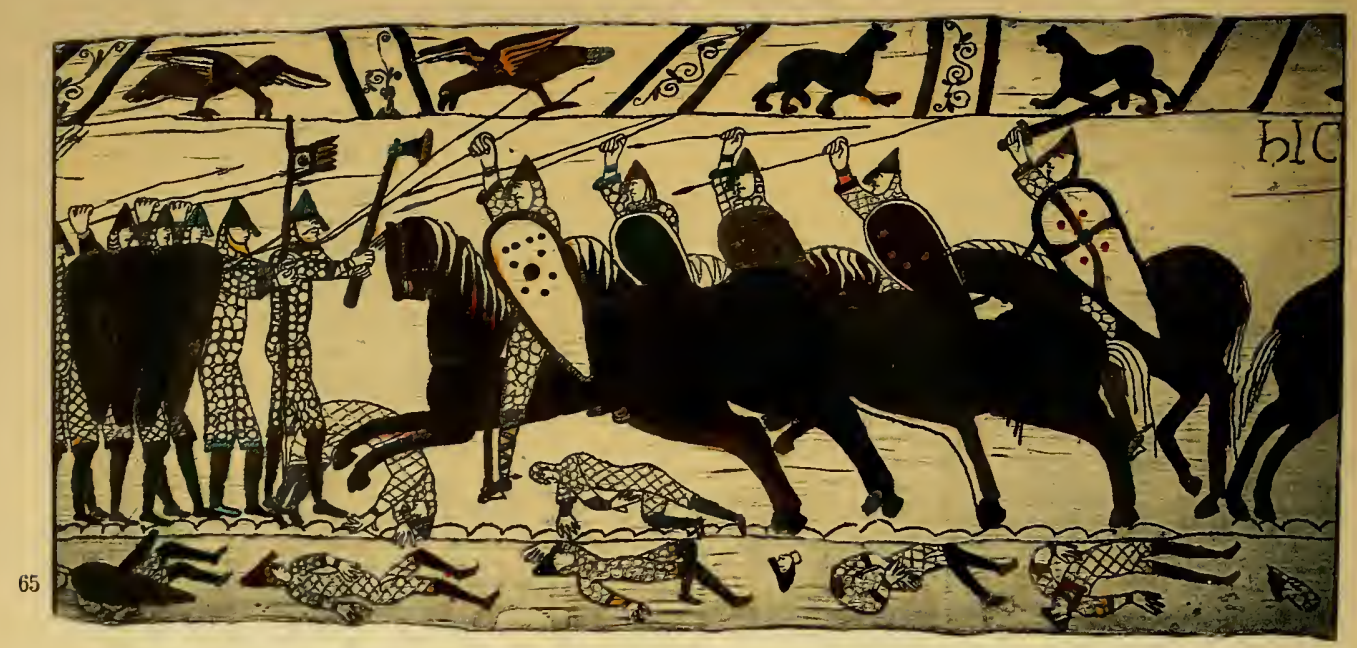

the missile weapon, to wit, to shake the enemy's infantry, upon which, so shaken, the cavalry should charge."

Now all this the artist has attempted to represent. You have the attack represented both to the right and to the left and falling upon a body which faces two fronts; this is to symbolise the convergence of the three columns upon the semicircular front of the Saxon position upon Battle Hill. No particular figures are given; not even Harold is to be distinguished. Some critics too ingenious have discovered in the head of the Norman charge the person of Taillefer, "Iron-shear," who certainly rode out before the army singing his song of Roncesvalles and tossing his sword (or by another account, his lance) into the air. There is nothing of this in the Tapestry.

The next two panels (66 and 67) give the death of the two brothers of Harold. Apart from the introduction of the figures of these two princes, Lewine and Gyrth, the interest of these panels also lies in the accoutrements. Thus on four of the charging French knights you see the crossed garters

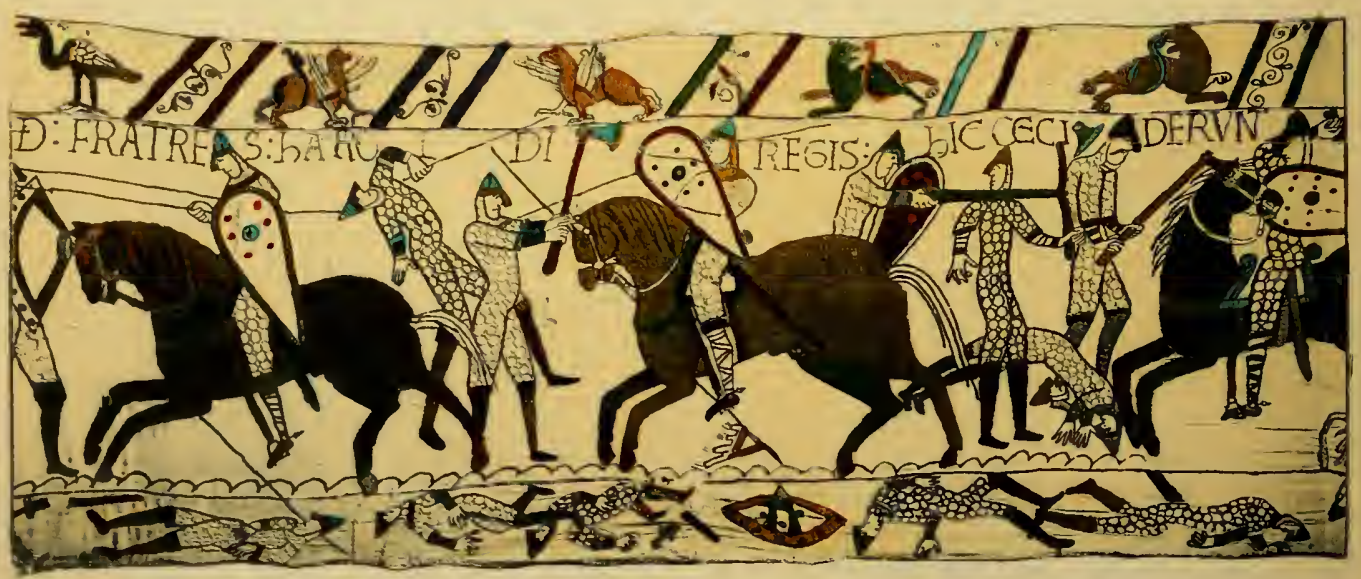




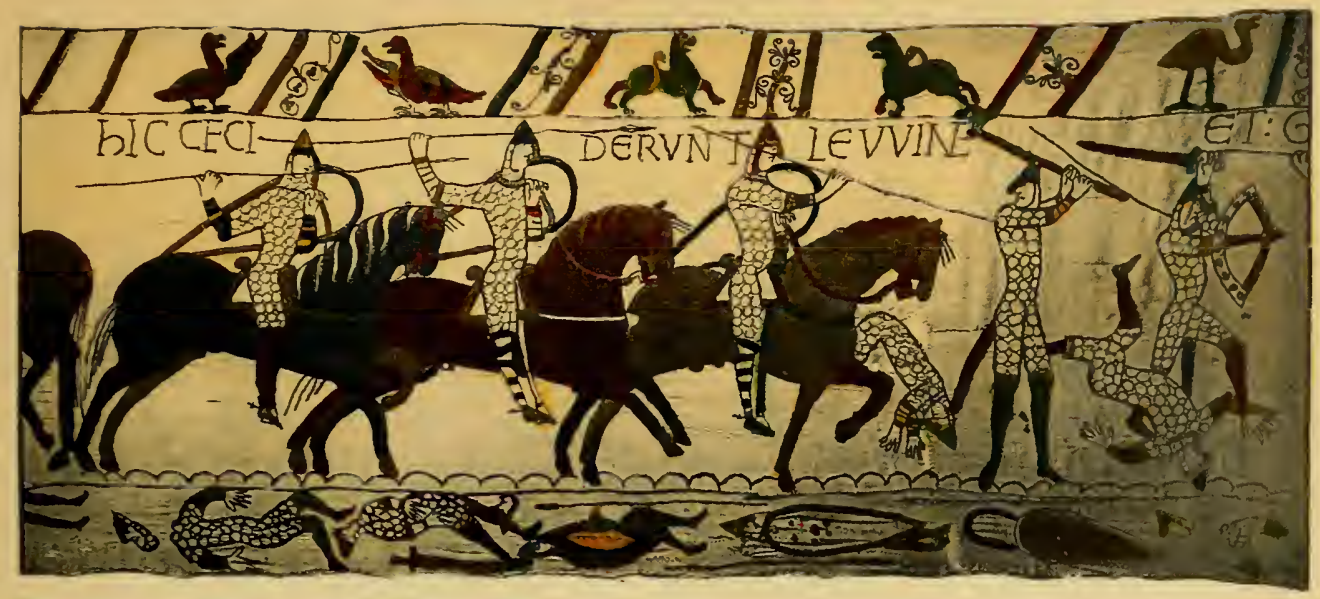

which bound the leg below the suit of mail, and in the hands of one of the English you see the round shield with a boss, which will reappear in the scene of the death of Harold. I would say tentatively and subject to correction, that this symbolised something old-fashioned in the Saxon accoutrement. In the border below, the same type of accoutrement, the round shield with the boss, reappears twice among the dead bodies. Gyrth and Lewine were standing near Harold, and one chronicle makes William himself fell Gyrth with a blow of his mace, but there is nothing of this in the embroidery. There is no figure armed with a mace and no mention of William. The $68 \mathrm{th}$ panel is the liveliest attempt the artist makes anywhere to represent the heat of the attack. It speaks for itself in the exaggerated catastrophes of the mounts and of their riders; but what should be particularly noted is the representation of the Hill of Battle, the horse stumbling at the approach of it and the defence by the Saxon footmen upon the summit.

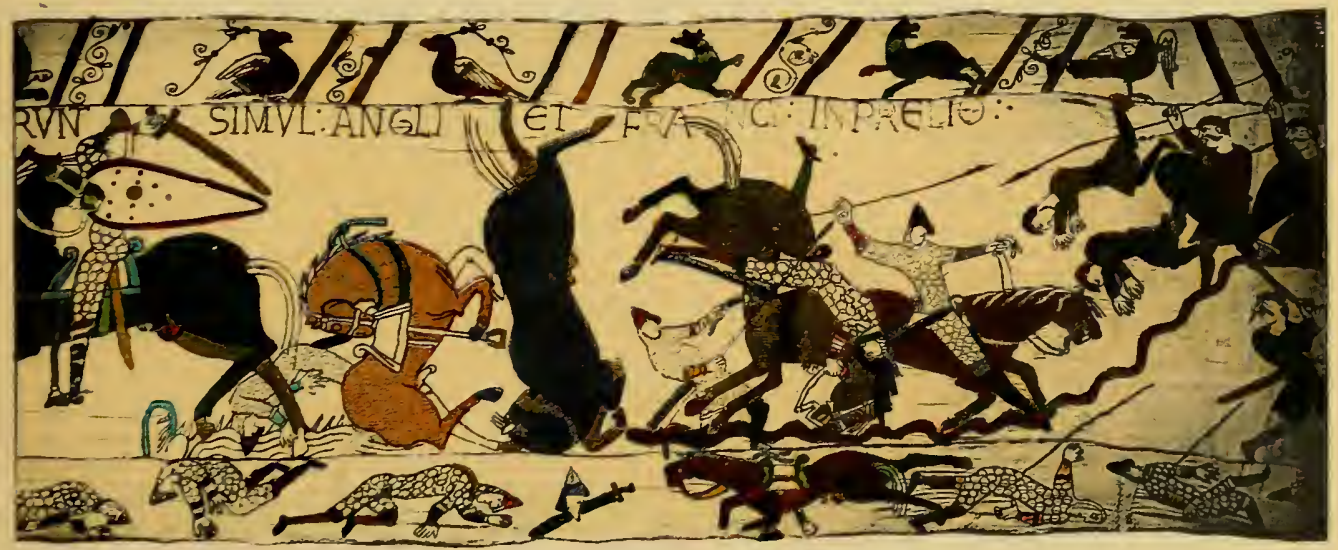





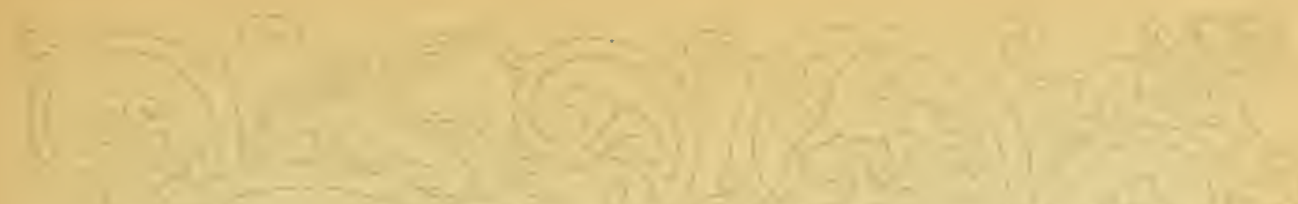

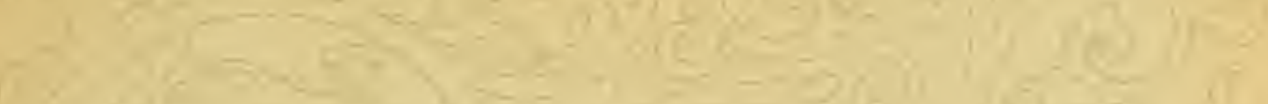

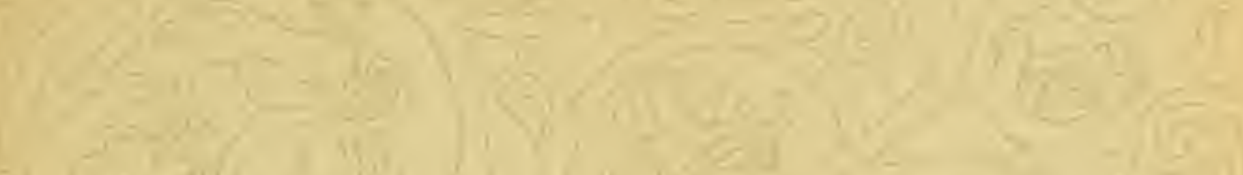

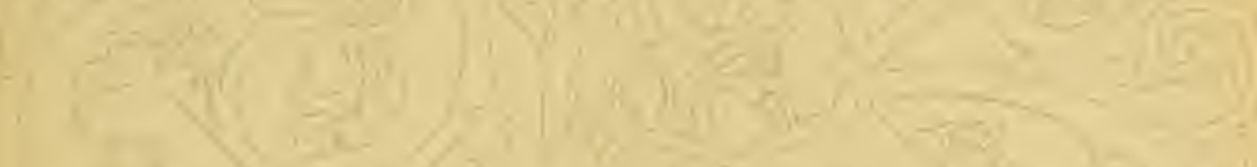

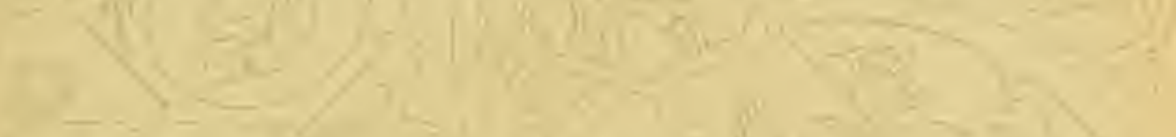

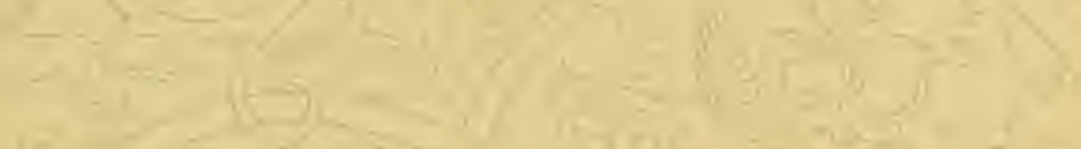

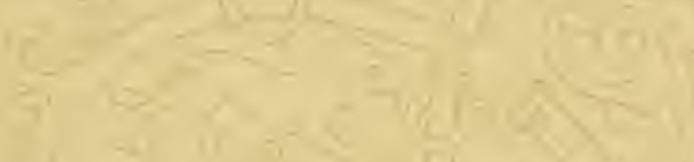

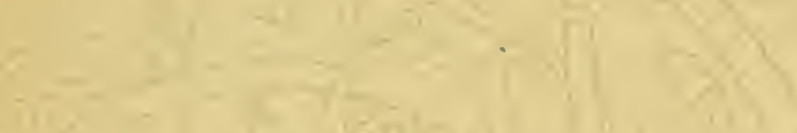

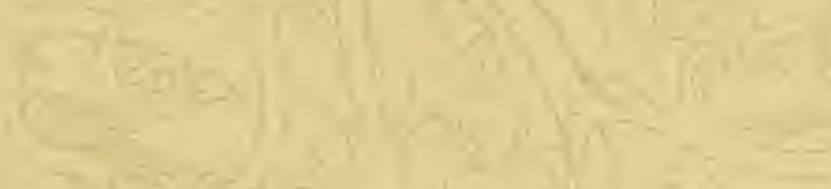

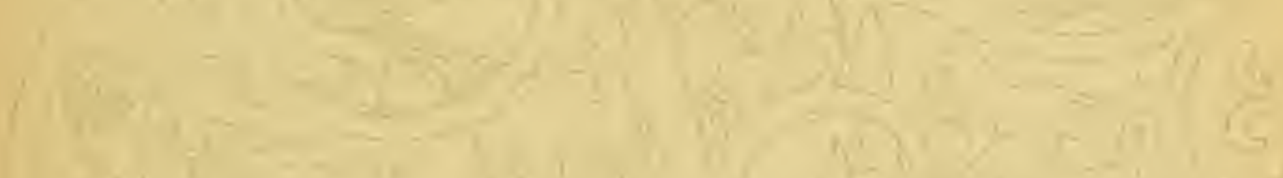

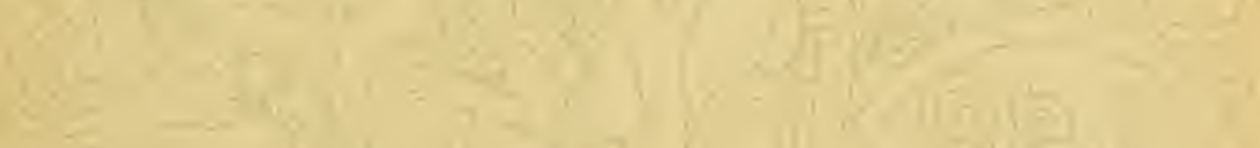

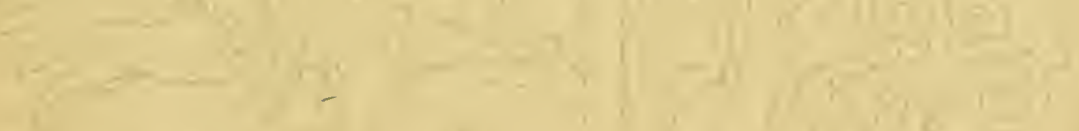

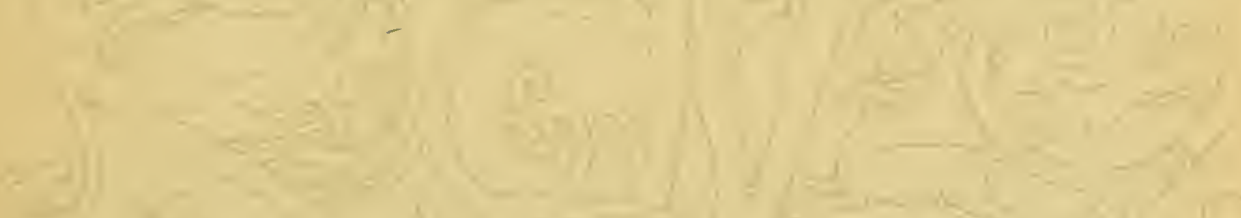

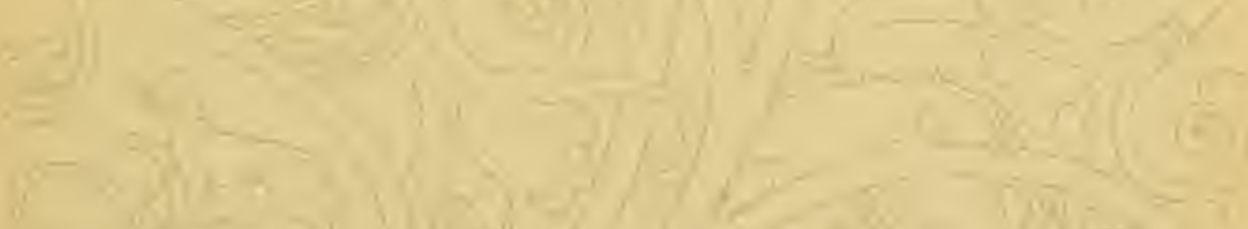

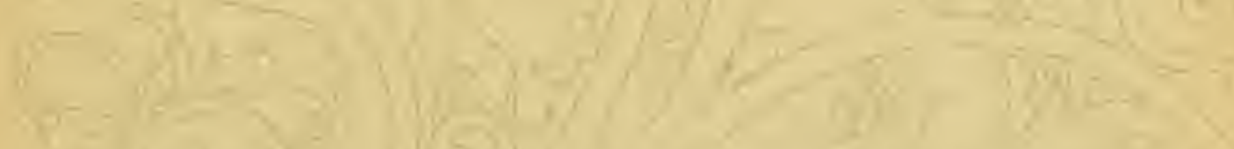

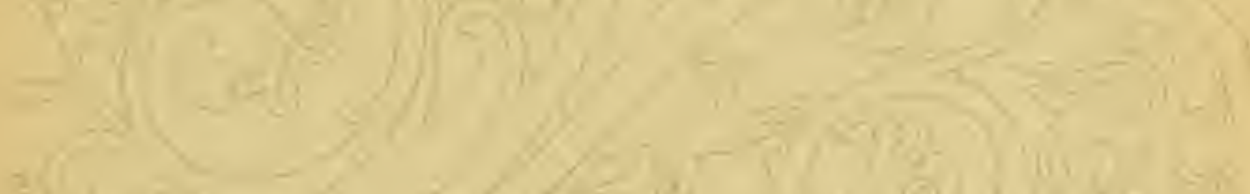

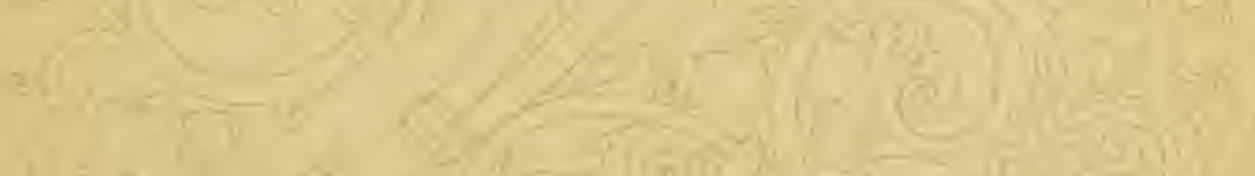

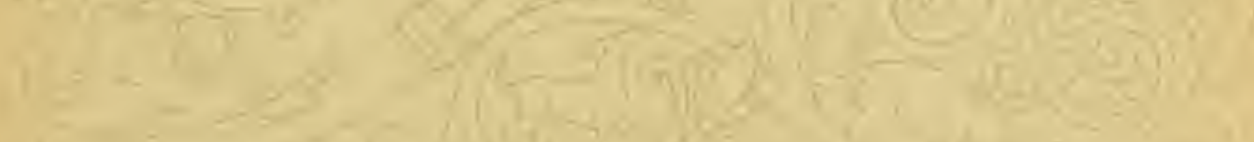

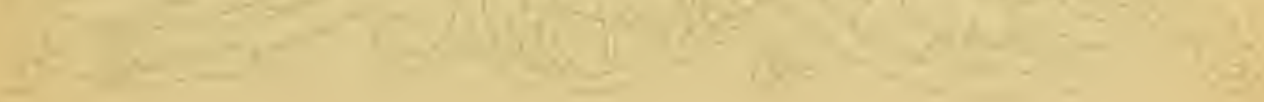




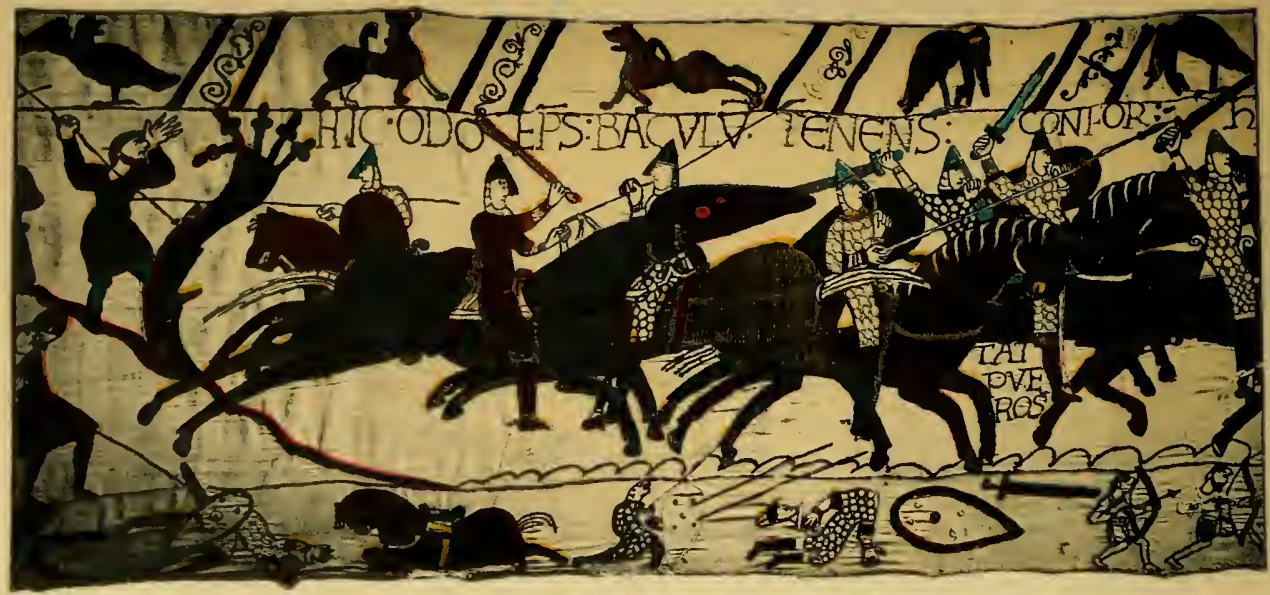

With the 69th panel we approach the attempts in the latter part of the Tapestry to introduce persons. This attempt has led to a considerable historical controversy, for while some points in the portraiture are obvious, ochers, as will be seen in a moment, lend themselves to discussion.

First we have, in the 69 th panel itself, Odo of Bayeux, the Bishop, William's brother, with the characteristically French inscription, "Pueros suos," by way of saying " his men." "Here Odo, the Bishop, holding a stick, heartens his men," or literally, "his children." So the modern French army term, "mes enfants" for "men." All this is quite clear; but the next panel (No. 70) has led to the controversy of which I speak. Note here three men at the charge. The first brandishes a sword, the second has a mace or sceptre in his hand, and is lifting the nasal of his helm, and the third holds a lance and pennon or, as the French then called it, a Gonfanon. Above the group is written, "Here is Duke William." It is fairly established that

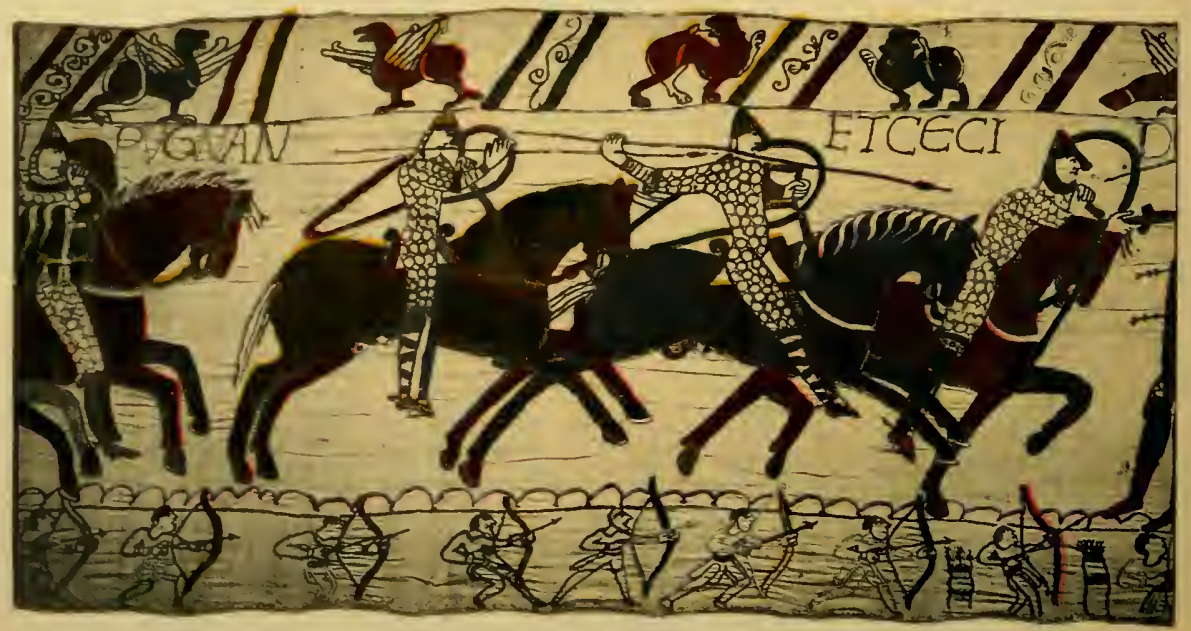




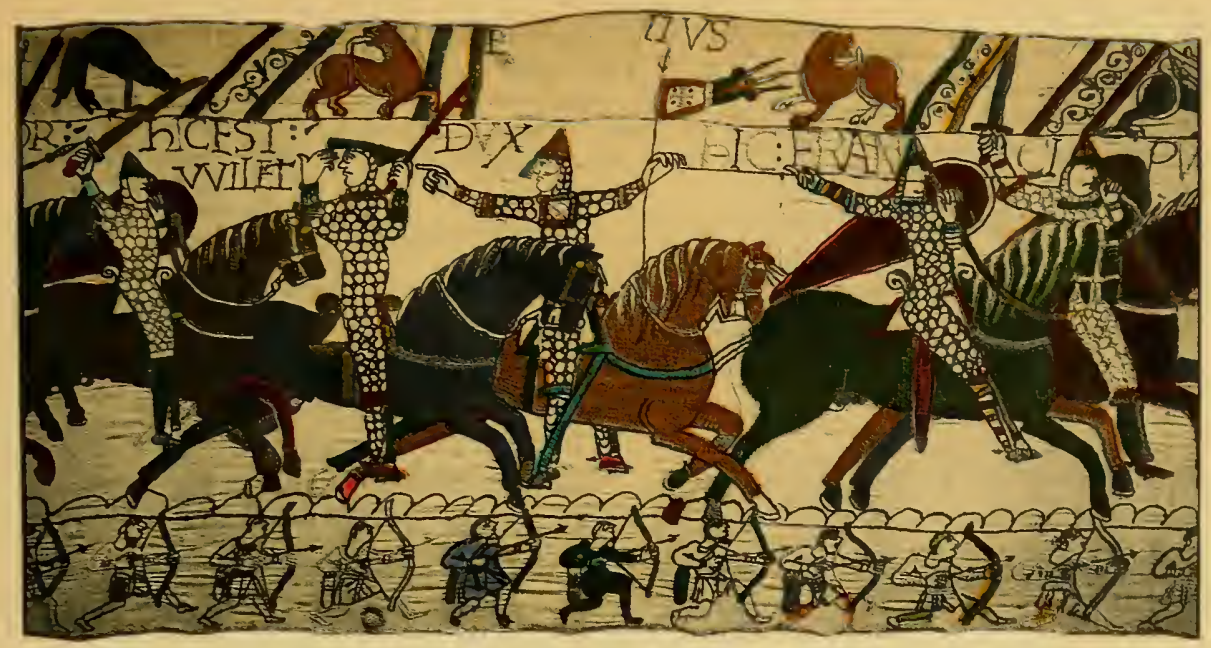

Wace's poem (which the panels of this part of the Tapestry follow with great fidelity) is here abandoned by the artist and the account of Benoit de Saint More is followed. The incident is, of course, that of William showing his face to his followers when it was feared he had fallen. Further, the first figure carrying the pennon is certainly intended for Eustace of Boulogne. Above his head, in one of the few fragments that have suffered mutilation, is the beginning and ending of the word Eustatius (E_-TIUS); while the clear writing of the inscription round the central figure and the obvious reference to the passage in Benoit de Saint More, coupled with the fact that the central figure bears a mace or sceptre, not a sword, leave no doubt that it is William that is intended. It is worth remembering in connection with the date of the Tapestry that the emphasizing of the part which Eustace of Boulogne played in the battle is peculiar to the twelfth-century chroniclers.

The next three panels are bringing the battle to an end. "Here," says

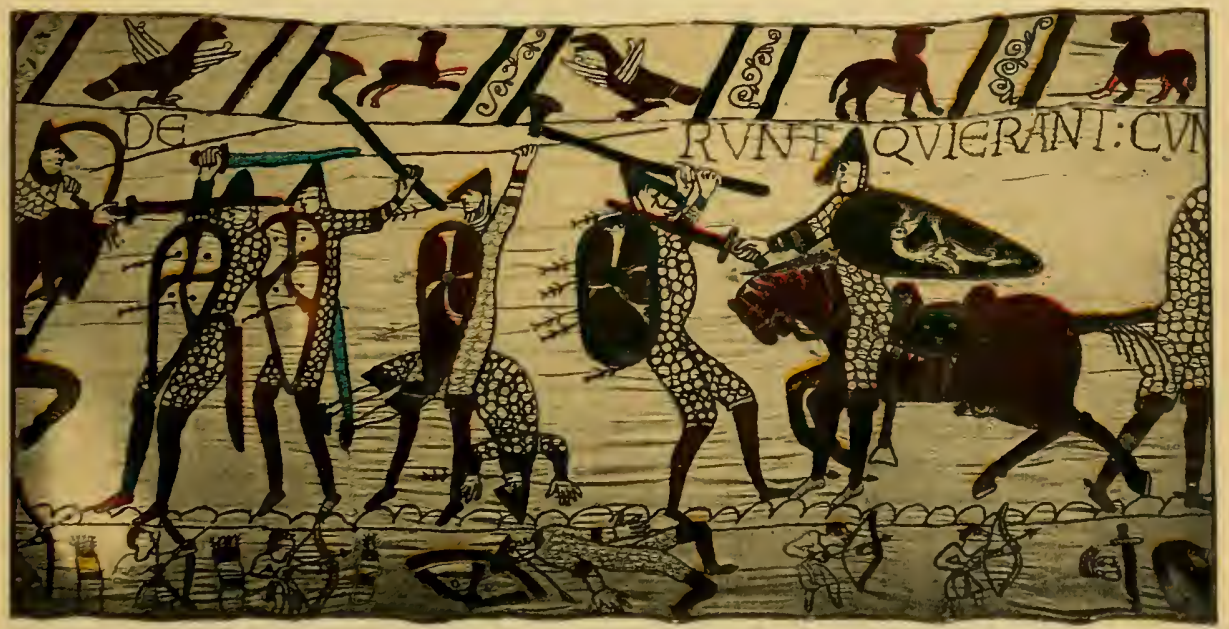



$=$

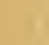

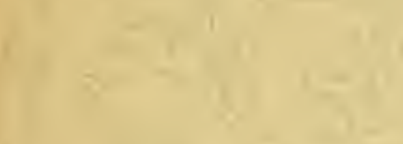

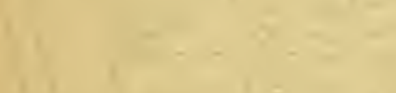

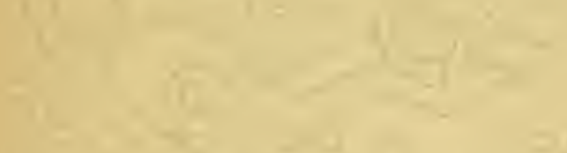
$=\left(\ln ^{-1}\right)$

S-

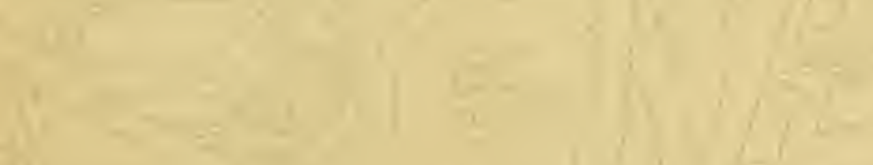

$-1+y^{-}+2$

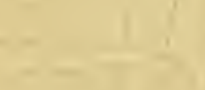

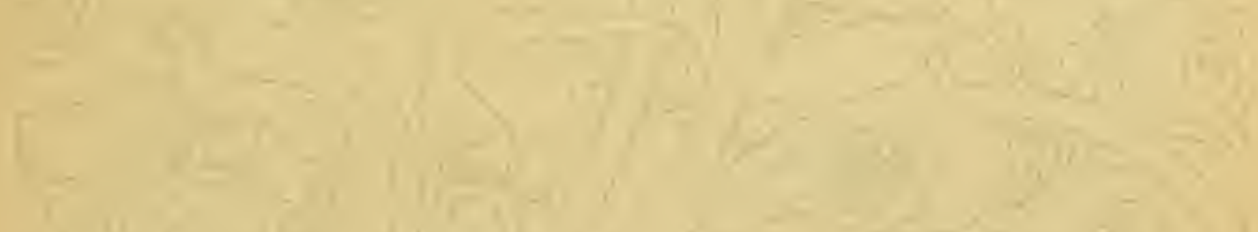

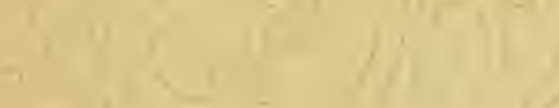

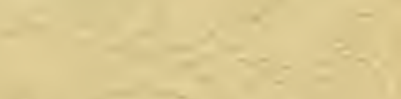

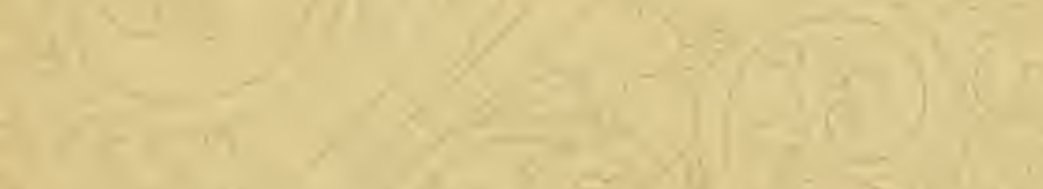

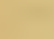
$x-$

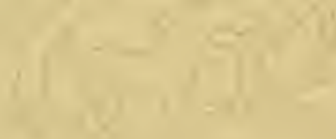




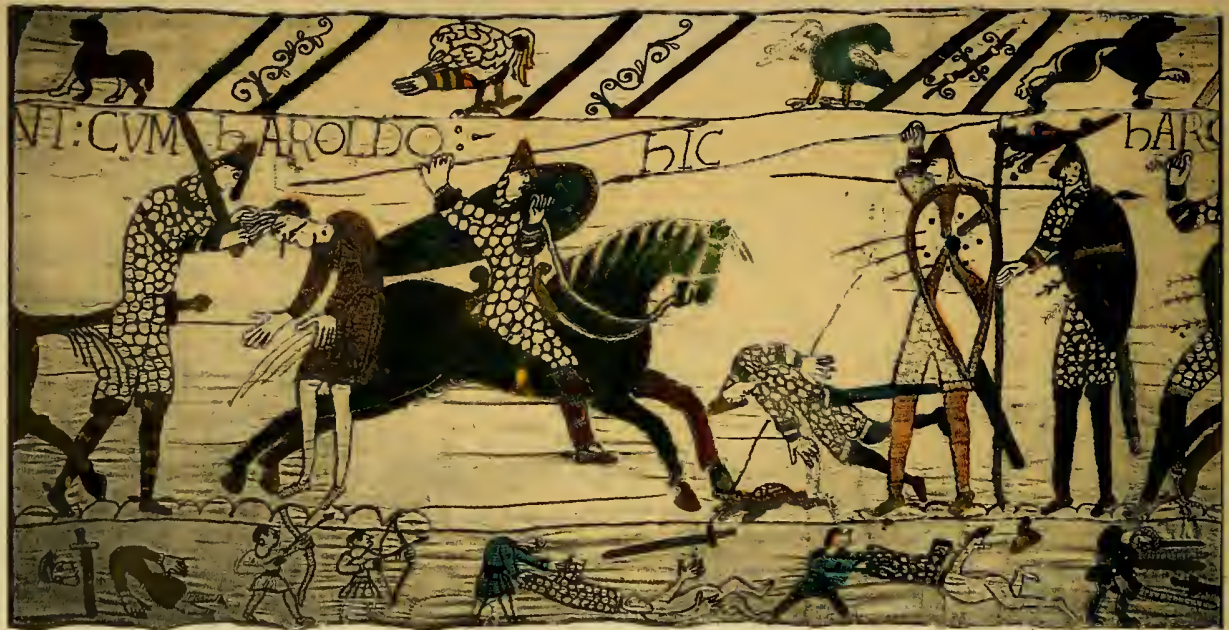

the inscription, "the French fight and slay those who were with Harold." The number of armorial shields, and their presence even, on the Saxon side is noteworthy, and the reappearance of the round shield with the boss in the border; further, that the archers have at last got home, is indicated in the arrows that have struck the shields, and in the full quivers of the border. The stripping of the bodies of the slain by the camp followers is equally indicative of the stage the fight has reached; and in the next panel (the $74^{\text {th }}$ ) you have one of the last episodes, the death of Harold himself. Harold is introduced twice: first, standing near his standard pulling from his face the arrow that has struck it; next, cut down by a mounted horseman, who strikes him on the thigh with his sword. That exactly follows Wace point for point, for his poem tells us first that Harold was struck in the eye by an arrow and that he pulled it out, and that then one came, a knight, who struck him on the thigh with a sword, wounding him to the bone; that at the same moment the standard fell to earth, and that the men "then killed Harold."

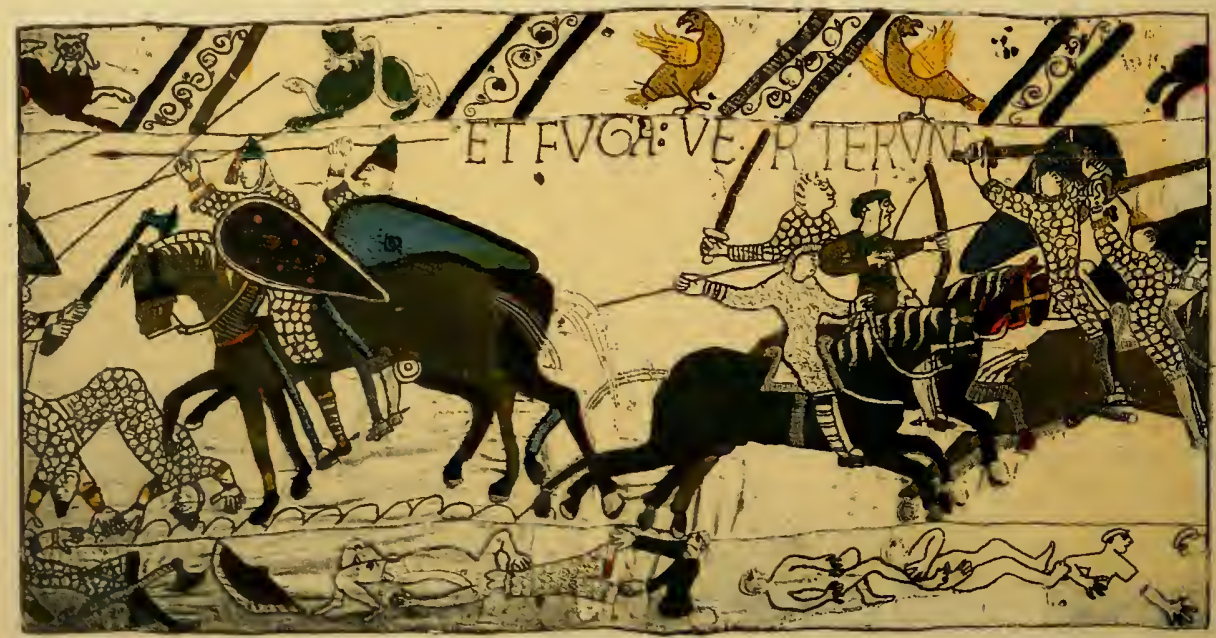




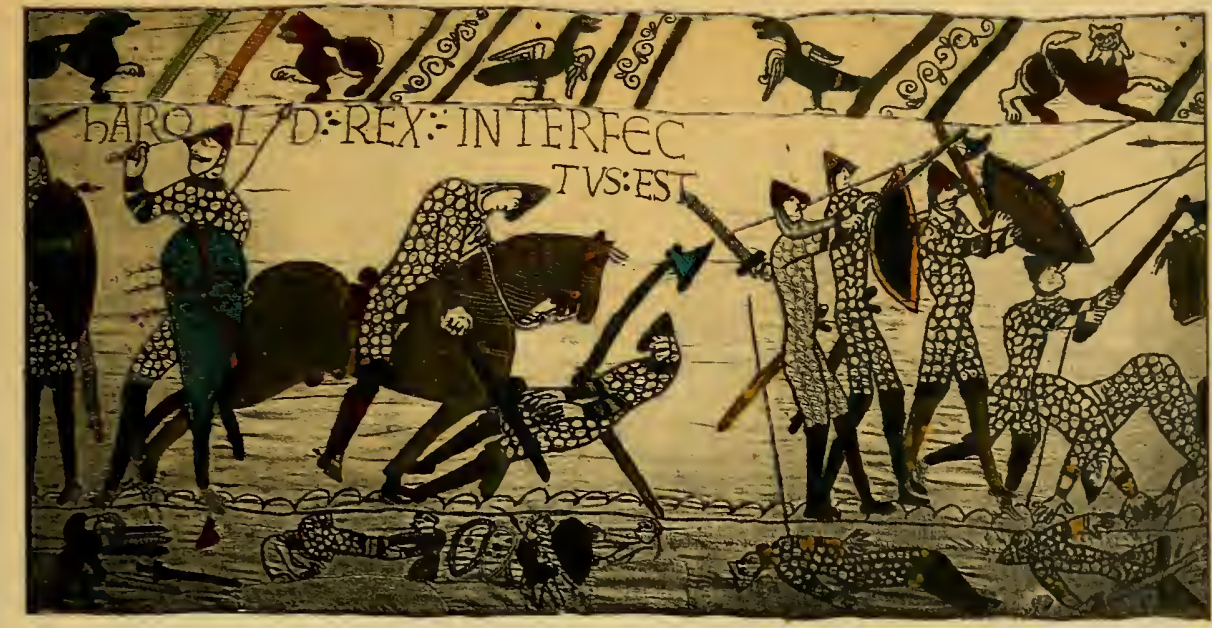

The last two panels ( 75 and 76 ) are the breaking of the ranks and the flight. They need no comment save perhaps one note: the conventional tree in the last panel may well enough stand for the wood of the Weald which lay behind the Saxon position, and into which the rout pressed as darkness fell.

It has been suggested thatthe Tapestry continued further than the point at which it now ends, both because it is somewhat frayed at that end and because in the description of another Tapestry (lost) the account of the day following the battle is given.

What seems to me to prove definitely that the Tapestry did end almost exactly where its frayed edge terminates it to-day, is the fact that it was exactly of a length to go round the nave of Bayeux Cathedral, and that the measurements of the existing stuff correspond with that length.

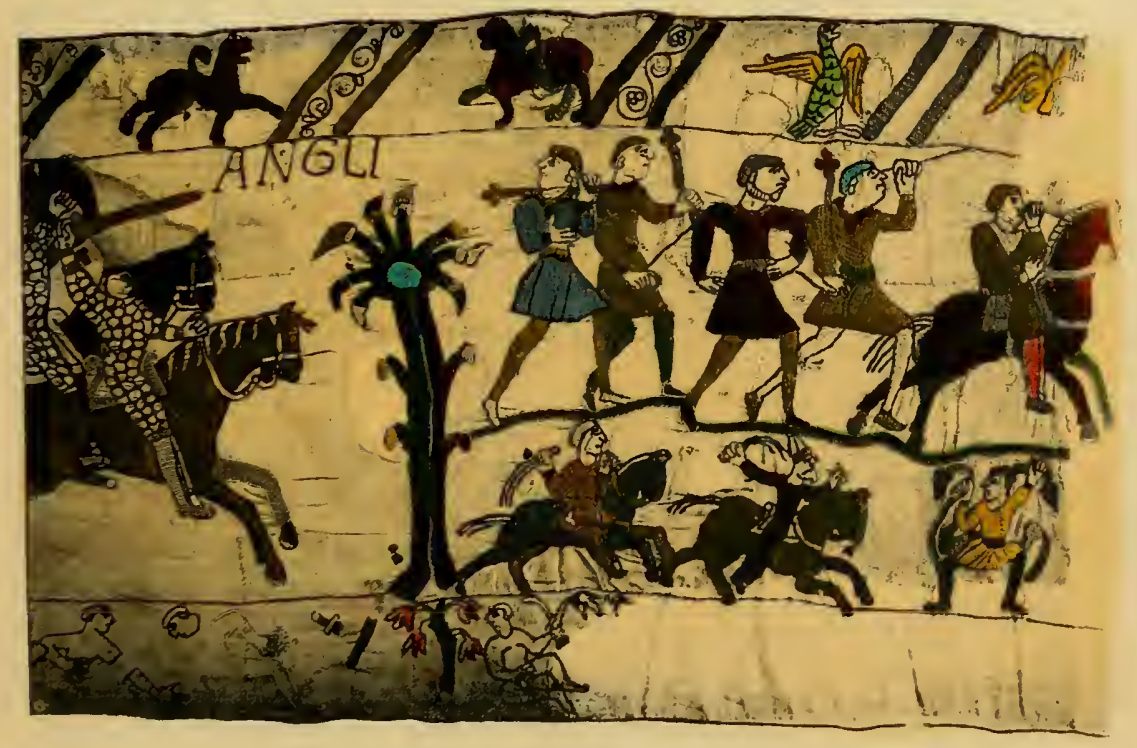






